Marta Cobel-Tokarska

\title{
Desert Island, Burrow, Grave
}

Wartime Hiding Places

of Jews in Occupied Poland

Studies in Jewish History

and Memory

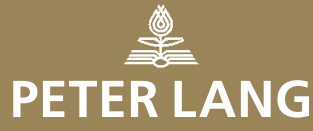


This book is an anthropological essay which aims to capture the elusive phenomenon of hideouts employed by Jews persecuted during the Second World War. Oscillating between life and death, the Jewish hideouts were a space of the most diverse and extremely complex human relations - a specific realm of everyday life, with its own inherent logic. Based on different literary sources, especially wartime and postwar testimonies of Jewish escapees, the author seeks to examine the realm of hideouts to develop a novel, interdisciplinary perspective on this often neglected aspect of the 20th-century history. of sociology of culture, anthropology, literature, and recent history. 
Desert Island, Burrow, Grave 
Studies in Jewish History and Memory

Edited by

Lucyna Aleksandrowicz-Pędich

Volume 11

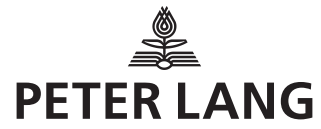


Marta Cobel-Tokarska

\title{
Desert Island, Burrow, Grave
}

Wartime Hiding Places of Jews in Occupied Poland

\author{
Translated by \\ Katarzyna Błachnio-Sitkiewicz
}

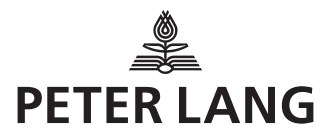


Bibliographic Information published by the Deutsche Nationalbibliothek The Deutsche Nationalbibliothek lists this publication in the Deutsche Nationalbibliografie; detailed bibliographic data is available in the internet at http://dnb.d-nb.de.

Library of Congress Cataloging-in-Publication Data A CIP catalog record for this book has been applied for at the Library of Congress.

The Publication is funded by the Ministry of Science and Higher Education of the Republic of Poland as a part of the National Program for the Development of the Humanities in years 2016-2018. This publication reflects the views only of the authors, and the Ministry cannot be held responsible for any use which may be made of the information contained therein.

NATIONAL PROGRAMME

FOR THE DEVELOPMENT OF HUMANITIES

ISSN 2364-1975 • ISBN 978-3-631-67438-3 (Print)

E-ISBN 978-3-653-06881-8 (E-PDF) • E-ISBN 978-3-631-70852-1 (EPUB)

E-ISBN 978-3-631-70853-8 (MOBI) • DOI 10.3726/978-3-653-06881-8

(C) Peter Lang $\mathrm{GmbH}$

Internationaler Verlag der Wissenschaften

Berlin 2018

All rights reserved.

Peter Lang - Berlin · Bern · Bruxelles · New York ·

Oxford $\cdot$ Warszawa $\cdot$ Wien

All parts of this publication are protected by copyright. Any utilisation outside the strict limits of the copyright law, without the permission of the publisher, is forbidden and liable to prosecution. This applies in particular to reproductions, translations, microfilming, and storage and processing in electronic retrieval systems.

This publication has been peer reviewed.

www.peterlang.com 




\section{Introduction to the English edition}

Desert Island, Burrow, Grave. Wartime Hiding Places of Jews in Occupied Poland book was published in Polish by IPN [Institute of National Remembrance] Publishing House in 2012. It was well received, nominated to "Polityka" Historical Award and Professor Tomasz Strzembosz award, and won an award for the best historical monograph "KLIO". It was discussed on "Przystanek Historia" (IPN) ["History station"], and during "Spotkania z Książką" ["Meetings with book"] at Academy of Special Education in Warsaw. It was debated at academic seminars, including ones at Institute of History at the University of Warsaw, at Institute of Applied Social Sciences at the University of Warsaw, at Jewish Historical Institute (Holocaust Literature Research Group), in Międzyzakładowa Pracownia Pamięci Społecznej [Interdepartmental Workshop of Social Memory] in Institute of Sociology at the University of Warsaw, in the department of History and Historiography of Eastern Europe at Catholic University of Lublin. I know that this monograph is being used during classes with students of, inter alia, history and sociology. This book was reviewed by important Polish sociological magazines: "Societas/Communitas" 2 (14) 2012, "Kultura i Społeczeństwo" ["Culture and Society"] 1 (LVII) 2013, "Porównania" ["Comparisons"] 13 (2013) and in a Czech magazine "Slavica Litteraria" 1-2/2013. Awareness-rising online portals have also published their reviews. Those include historia.org, przezhistorie.pl, dzieje.pl and website of POLIN Museum of the History of Polish Jews. Copies of the book in Polish were sent to the most distinguished scientific facilities, including Yad Vashem and United States Holocaust Memorial Museum (USHMM) in Washington.

The time has come to present this work to a broader group of readers by translating it into English. It was possible thanks to getting a grant from Narodowy Program Rozwoju Humanistyki [National Programme for the Development Humanities] (3aH 150143 83) and Peter Lang publishing house.

Despite the time that has passed since the book was published in Polish, I can still sign off on every word from the "Introduction". Numerous notable papers on the Shoah have been published since that time. The subject of hiding places, where the Jews were trying to save their lives on the territory of occupied Poland, has not yet been presented in any significant monographs solely on that subject. However, this subject is still present in the scientific, journalistic and artistic discourse. There are still authors who consider hiding places to be worth deliberating, describing, and presenting. For example, I can mention Oscar nominated 
Agnieszka Holland's movie In Darkness [W ciemności] (2011) based on memories of the Chiger family, hiding in the sewers of Lviv, Oscar winning Paweł Pawlikowski's movie Ida (2013), a play based on history of Apolonia Starzec: Hideout/ Kryjówka (2015, directed by Paweł Passini, screenplay by Patrycja Dołowy), or the most recent The Zookeeper's Wife (2017) movie based on memories of Antonina Żabińska, who was sheltering Jews in the Warsaw ZOO. Therefore, my book still serves its purpose and is still needed.

I would like to thank everybody who contributed to creation of this book, both the original version and translation. I apologize to everybody I have not mentioned. At the same time, I would like to stress that all the mistakes and inconsistencies in the book are my doing alone.

In the acknowledgements, I go back in time to when my adventure with writing and science was only just beginning. It all began in 2001-2003 at the University of Warsaw, in the Institute of Polish Culture, where professors Barbara Engelking and Jacek Leociak conducted a seminar entitled Getto Warszawskie. Próba odczytania doświadczenia Holocaustu w kontekście historii i kultury Żydów [An attempt to comprehend the experience of the Holocaust in the context of history and culture of the Jews]. I happened to attend these fascinating classes thanks to Małgorzata Preuss, whom I would like to cordially thank for contributing to a breakthrough in my professional life. Later I began studies at School of Social Sciences at Institute of Philosophy and Sociology of Polish Academy of Sciences [PAN - Polska Akademia Nauk], where I have learnt everything that I know about sociology today. For that I wish to thank both all the professors lecturing there and my colleagues.

The biggest and most important thanks should go to professor Barbara Engelking. If it was not for her, we would not write this book, I would not know anything about the Shoah, and I would never begin my research.

Each chapter of my doctoral dissertation, which was the base for the text of this book, received its final shape as a result of discussions during scientific seminars conducted by professor Barbara Engelking at the Institute of Philosophy and Sociology of PAN. Małgorzata Preuss, Alina Skibińska, Ewa KoźmińskaFrejlak, Marta Janczewska, Marta Pietrzykowska, Agnieszka Haska, Aleksandra Bańkowska, Zuzanna Schnepf-Kołacz, and Justyna Majewska participated in those seminars. I would like to thank them all for years of fascinating work together, Joanna Wawrzyniak for the first critical reading of the book, and professor Małgorzata Melchior and Elżbieta Tarkowska for the first reviews.

I would like to thank Michał, Włodzimierz and Grażyna Strzelczyk who let me write this book in their hospitable home. 
I wish to thank everybody who inspired me (often inadvertently), who supported me and assisted in the writing process. Their influence can hardly be overestimated. Lectures, conversations, readings, cooperation with them allowed me to write what I did. I want to especially thank Jean-Yves Potel, Piotr Filipkowski, and professor Joanna Tokarska-Bakir. I wish to thank all my friends, who stayed by me and motivated me to work.

I would like to thank Anka Grupińska and all my colleagues from Centropa, Witness to the Jewish Century and Zapisywanie świata żydowskiego w Polsce [Records on the Jewish world in Poland] of Museum of the History of Polish Jews projects, especially my friends, Zofia Wieluńska and Magda Bizoń, and all the people whom I had the honor to interview within the frameworks of those projects.

I would like to thank Aleksandra Bańkowska, Jan Jagielski and other employees of the Jewish Historical Institute who helped me in archive query.

My heartfelt thanks to professors Marcin Kula and Małgorzata Melchior for an immense support, kindness and assistance in all the endeavors connected with this book. I would like to also thank professors Marcin Zaremba, Szewach Weiss, and Jan Grabowski.

I would like to thank Dagmara Mańka-Wizor, Bogumiła Drwal and other associates from KARTA Center.

I would like to thank the employees of IPN publishing house [Institute of National Remembrance], especially Piotr Chojnacki, the editor of Polish edition, Dorota Mazek, Agnieszka Górkiewicz, and Renata Bieniek from "Przystanek Historia" for her relentless enthusiasm in promoting the book. I would like to thank the organizers of all the seminars, meetings, and conferences for a chance to present my book and to talk about it, I would like to thank the readers for the discussions and their valuable input.

I would like to thank the authors of reviews and reports, especially Bartłomiej Krupa, for their insightful impressions and thorough analysis of my way of thinking. My thanks go to Elżbieta Janicka for her critical observations.

I would like to thank Zuzanna Bogumil, who inspired me to attempt to get NPRH grant. My sincere thanks to Łukasz Gałecki, Katarzyna Szyniszewska, and Krzysztof Kozina for helping me get and use the grant and work on English translation of the book.

Above all, I would like to thank my wonderful translator, Katarzyna BłachnioSitkiewicz. We understand each other "without words". I would also like to thank my editor, Jan Burzyński.

I wish to thank professor Anna Firkowska-Mankiewicz, thanks to whom I came to Academy of Special Education, and all the associates and university authorities 
who created the conditions for scientific work; especially the Deans: professor Jan Łaszczyk, professor Stefan Kwiatkowski, and professor Jarosław Rola, for their kindness and support.

I would like to thank all the readers of Polish edition of the book, especially the first ones: my uncle Sławek and dad.

I dedicate this work to memory of professor Elżbieta Tarkowska, who was my biggest authority in science and in life, but also the best boss and inspiration who always supported me on the path of science.

I also dedicate it to my loved ones: Paweł, Tadzio and Janeczka. 


\section{Translator's foreword}

When I first heard about a possibility of this book being translated into English, I was simply overjoyed. I have known Marta Cobel-Tokarska personally for a few years now and she was, in fact, one of my first clients who trusted me at the very beginning of my professional career. As she kindly wrote in the introduction to the English edition of this book, we understand each other perfectly, which is why I was sure that my work on this translation will be a highly satisfying challenge. However, I got a lot more than I bargained for, as I was not only translating Marta's words but also trying to convey the voices of all the authors of the academic writings cited here, and, more importantly, of the authors of journals, diaries and testimonies who wrote about their unimaginable fates.

By making a great use of the sources, Marta gave me an opportunity to work with a different author during every day of the translation process. The authors led me to their most secret world and made me feel their joy after they got a fragrant tomato in their hiding place, their emptiness when glancing at a village that was once their home, their anger, despair, fear, and even boredom. I got to translate technical descriptions of elaborate hatches and dugouts, an interesting conversation in a heavy dialect, poignant cries for help and astonishingly poetic descriptions of states and feelings that cannot be named. I listened to the voices of resourceful, brave, sensitive and witty people, each of them with their own exceptional truth to tell. I earnestly hope that I did them justice and not lost in translation what makes them unique.

I believe that thanks to its complexity and diversity of the sources this book will prove not only to be a great read for sociologists, but also for historians, architects and everybody who wishes to know more about this often-neglected space from the history of the Shoah - the space of a hiding place.

For making this translation possible, my thanks go to Marta Cobel-Tokarska for believing in me and creating this compelling read, professor Marcin Zaremba for his kind words and recommendation, my husband Maciej for his unmatched patience and support, and my cats - true translator's friends.

Katarzyna Błachnio-Sitkiewicz 



\section{Contents}

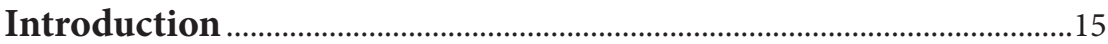

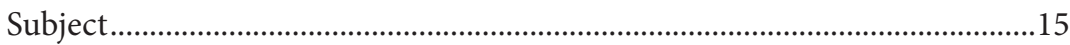

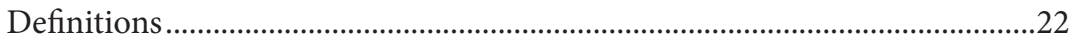

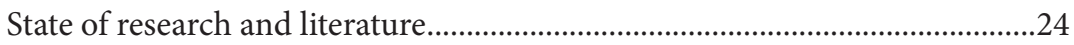

Research questions, structure ………………………………...............................33

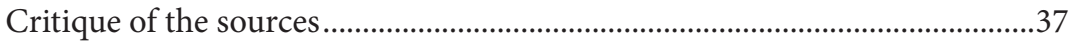

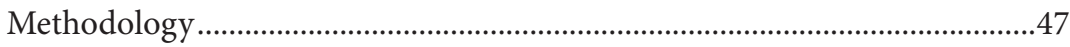

1 An attempted typology of the hiding places …………………….........53

Temporary and long-term hiding places.............................................................54

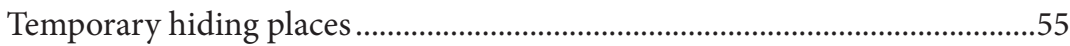

Long-term hiding places....................................................................................62

Independent-assisted hiding places ...................................................................69

Hiding places "under the same roof" .................................................................77

Hiding places "at a distance" ................................................................................ 81

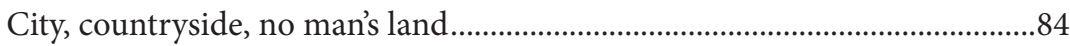

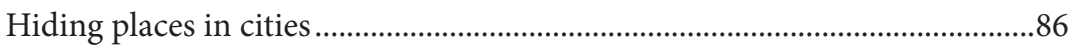

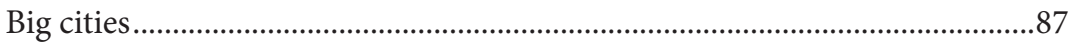

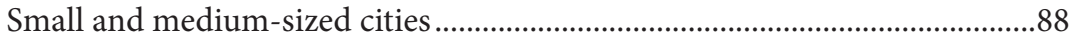

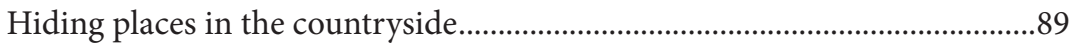

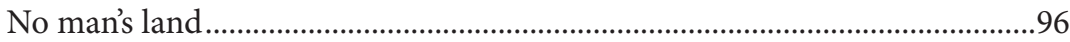

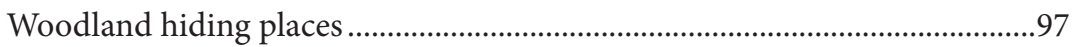

Concentration camps, labor camps, death camps, places of execution and other "excluded areas" .............................................................. 100

Solitary - collective hiding places .................................................................... 105 


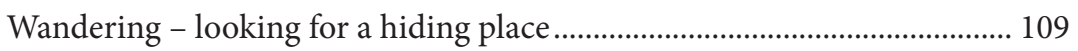

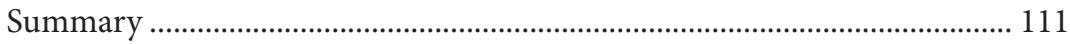

2 Hiding place as a space. Perspective of social and individual experience ............................................................................... 113

Part I. Hiding place as a social space ............................................................. 113

Part II. Individual perception of space ……………....................................... 130

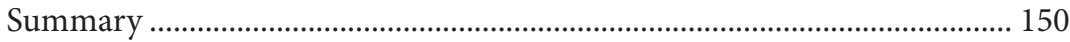

3 Meanings in a space of a hiding place .............................................. 153

Space of a hiding place - in search for meanings.............................................. 155

Center and peripheries, oppositions of directions, the sacred and

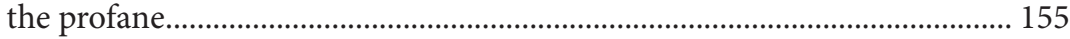

Availability and boundaries ........................................................................ 158

Symbolical spaces of hiding places, archetypes and meanings

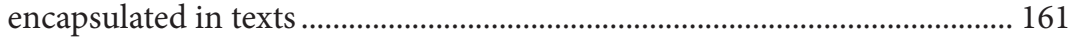

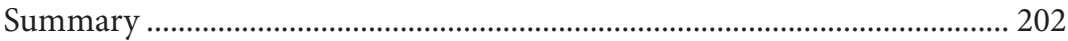

4 Hiding place and a home …………………………………………..... 205

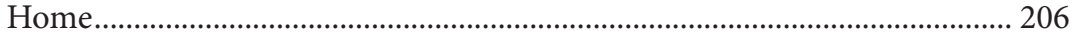

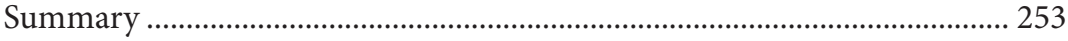

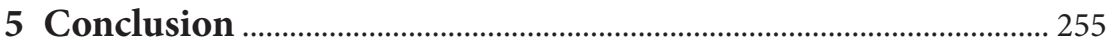

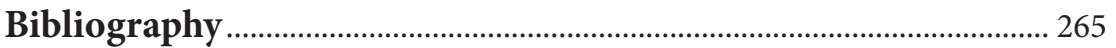

Index 


\section{Introduction}

We can't truly enter an apartment with a hidden Jew, we can't squeeze behind a wardrobe, into a corner of a room. Our imagination shies away from what we could find there, we have no words and are not ready to face the emotions we feel when accompanying such a situation. We sense hell.

Krzysztof Szwajca ${ }^{1}$

\section{Subject}

In this book, I am dealing with the spatial aspect of hiding places from the Second World War on the territory of Poland used by Jews hiding in ghettos (most often during "displacement actions") and on "the Aryan side". Why am I interested in the social phenomenon of a particular group of people hiding on the territory of the occupied country, a phenomenon that is so distant in time? Why have I chosen the category of space to describe them? In what follows I will try to briefly answer those questions.

Physical presence in the world is something obvious; it is a fundamental human right. Somebody who lives is also present. Others can see that person's body. That person can interact with the physical and psychological presence of other people and with the surrounding space. To be physically present and visible means to have a right to space, freedom of movement, and ability to satisfy one's needs with dignity; in other words - a right to function in the society.

During the Second World War, the Germans have challenged that natural order, shaping a new social reality in occupied countries. Apart from other restrictions, they have isolated groups of people that were unwanted in the society, for whom there was no place in the world they were creating. Wartime regulations introduced by the German occupant condemned those people to non-existence. In life-threatening situations, the right to occupy a scrap of space, to be visible and to be present is questioned. People stripped of that law have to hide, take their presence underground. It would seem that it is only possible to exist or not to exist, there appears to be no third option. Yet hiding, living "beneath the surface" is that third way, a compromise between wishing to save one's life and inability to manifest that life on the outside. One can cross a border of life just as easily as the border of death, return to the visible world or die because of not disappearing well enough.

1 Szwajca K., Kłopotliwa "świętość" [Troublesome "Sanctity”], "Midrasz" 2007, No. 1. 
The Jews who decided to hide during the Shoah have suddenly found themselves in a space that was limited in a physical, social, and symbolical way. From that moment forward a hiding place they chose or where they happened to be by chance became their world. They could only escape its limits with their thoughts. When reading the testimonies of the hiding people, I was to some extent able to peek inside that underground, mysterious world, where thousands of people used to live secret lives against all odds. That is what I am writing about - hiding places, third way, liminal stage between existence and non-existence.

The phenomenon of Jewish hiding places is a part of history of Polish Jews during the Second World War. I believe it is not necessary to prove how much the subject of the Holocaust itself is important and worthy of academic interest. The issue of its importance is taken up, for example, by a collection of essays entitled Why Should We Teach about the Holocaust ${ }^{2}$. Distinguished Polish scientists, educators, and specialists of various fields argue that there is a need to preserve the memory of extermination of Polish Jews in process of education - I believe that the same arguments can be raised in relation to academia. Authors approach this subject from various angles. Jerzy Tomaszewski stresses centuries-old coexistence of Jewish and Polish societies, showing how much the Shoah has impoverished Polish society and culture. Stanisław Krajewski argues that the need for knowledge about the Shoah is everywhere, as this was an exceptional event in the history of humankind. Sergiusz Kowalski goes a step further in his essay entitled It's Obvious. He says: "Why should we teach about the Shoah? And why not? After all, it happened on the territory of Poland fairly recently, during the course of life of my parents' generation. We are not asking whether we should teach it - we teach about older events, good and bad. About the dynasties of Polish kings [...], about partitions of Poland, uprisings, and positivism. [...] Then why shouldn't we teach about the Shoah, which claimed millions of Jewish citizens of Poland and Jews from all over Europe [...]. This is indeed the most important reason. We have to teach. Just because it happened. Because it is a part - and a very important one - of Polish modern history"3. The subject of the Shoah has been present in Polish culture for years. It is in poetry, movies, novels, it is a silent background of Polish postwar history. Despite all that it still requires in-depth studies and research exploring the still not detailed areas thereof.

2 Dlaczego należy uczyć o Holokauście [Why Should We Teach about the Holocaust], eds. J. Ambrosewicz-Jacob, L. Hońdo, Cracow 2005.

3 S. Kowalski, To oczywiste [It's Obvious], in: Dlaczego należy uczyć... [Why Should We Teach...], p. 56. 
Another important point which highlights the significance of the subject is the number of publications on the Shoah in various research context created to date. After the immediate post-war period, marked by an abundance of publications about the Holocaust, Polish science has openly addressed the subject only since about the last quarter of the century ${ }^{4}$. Polish scholars working in The Polish Center for Holocaust Research of the Institute and Sociology of the Polish Academy of Sciences write about that in their editorial foreword to the first issue of "Zagłada Żydów” [Holocaust] annual journal: "[...] there is a lot to make up for. The conditions in the Polish People's Republic - unfavorable political climate, censorship, lack of working contacts with western historiography, break of continuity in domestic research on the Shoah caused by the destructive activities of 1968 and the following years - it all caused stagnation and marginalization of Polish research on the fate of the Jews during the Second World War"5. The authors continued that only the recent years have observed a visible change in this scientific paradigm - on the one hand, thanks to including new or forgotten sources into the academic circulation, and on the other hand, thanks to new generations of researchers who address the subject of the Shoah in their works without biases and limitations, tapping into the works of specialists in this field from Poland and from around the world.

While determining the scope of the studies, we need to think about to what extent the past can at all be the subject of a sociological work. This dilemma is resolved by Małgorzata Melchior in her The Holocaust and Identity. The author invokes Krystyna Kersten's opinion. The latter proved that while it is true that history deals with res gestae, i.e. human acts performed in the past, it is impossible to set a definitive border between the past and the presence of societies ${ }^{7}$. This is true especially when that past means fairly not so distant times, particularly the ones that are still present in social consciousness. This is the case of the

4 According to Ewa Koźmińska-Frejlak information (overview of publications on the Shoah published in 1945-1989 she carried out in 1990 commissioned by Michael Steinlauf based on item and systematic catalogue of National Library) as many as $25 \%$ of books were published in 1945-1949, majority of them were issued by Jewish organizations, mainly Central Jewish Historical Commission at Central Committee of Polish Jews.

5 “Zagłada Żydów” [Holocaust] 2005, No. 1.

6 M. Melchior, Zagłada a tożsamość [The Holocaust and Identity], Warsaw 2004 (chapter "Methodological Notes and Fundamental Theoretical Issues").

7 K. Kersten, Relacje jako typ źródła historycznego [Testimonies as a Type of Historical Source], "Kultura i Społeczeństwo" [Culture and Society] 1970, No. 14(3). 
Second World War, occupation of Poland and the Holocaust. Many people who personally experienced the events of that period are still alive, but those events are also indirectly affecting the second and third generation ${ }^{8}$.

Subjects connected with the Second World War are constantly present in general discourse, especially the areas that were tabooed for decades. Polish-Jewish relations are undoubtedly one of those areas, especially the most controversial aspects thereof - szmalcownictwo [a pejorative term meaning blackmailing Jewish escapees or the Poles who help them - translator's note], violence toward the hiding Jews, active participation of Poles in the Shoah, taking over Jewish property, difficult fate of Polish Righteous Among the Nations. It is sufficient to mention Polish nationwide debate that lasted for months, which began with release of Jan T. Gross's book in 2000 entitled Neighbors, or a bit less intense, but still symptomatic debate in 2008 connected with Fear by the same author.

In the above-mentioned work, Małgorzata Melchior writes that sociological study of events distant in time presupposes looking at them from the modern perspective - i.e. reflection about how are those events remembered today and how the participants thereof talk about them, how did they influence their current lives. Initially, when I was collecting the materials, I have attempted to build on that recommendation and analyze texts of in-depth interviews with witnesses and participants of the events that interest me, i.e. the people who were hiding during the war. Unfortunately, as I was conducting the interviews, it turned out that pursuing those assumptions would, in practice, require completely changing the scope of the research. Therefore, I have decided to use other types of sources, predominantly ones created during the war or shortly after it ended. I write more on the subject in the subsection on critique of the sources.

8 In fact there already is extensive literature on the "second generation", i.e. the children of the people who survived the Shoah (see I. Kogan, The Cry of Mute Children: A Psychoanalytic Perspective of the Second Generation of the Holocaust, London 1995; A. Hass, In the Shadow of the Holocaust: The Second Generation, New York 1996; A.L. Berger, Ashes and Hope: The Holocaust in Second Generation American Literature, in: Reflections of the Holocaust in Art and Literature, ed. R.L. Braham, New York 1990; Children of Job: American Second-Generation Witnesses to the Holocaust, New York 1997; Second Generation Voices: Reflections by Children of Holocaust Survivors and Perpetrators, eds. A.L. Berger, N. Berger, Syracuse 2001; in Poland this subject is addressed by inter alia Maria Orwid, Krzysztof Szwajca, Joanna Wiszniewicz and Łukasz Biedka). 
Why have I precisely chosen hiding places from the magnitude of themes and issues that can be distinguished in the history of the Shoah? The answer to that question is complex. First of all, I have for years searched for the least researched and described area in the subject with which I am fascinated. I shall write more on the state of research on the subject of hiding places and more broadly - hiding - in the latter part of the introduction. I will only mention here that in comparison with, for example, the issue of death camps or the Warsaw Ghetto this problem seemed to me to be completely unexplored. And yet this subject is very important, as it is an integral part of Jewish experience during the Shoah. Naturally, compared to the number of people killed in the camps we can estimate that hiding "on the Aryan side" was experienced by minority of people. I am also considering the experiences of people hiding from the Germans during liquidations of ghettos. This is still a minority - yet a significant and important one. I think that we cannot marginalize the problem of hiding places for quantitative reasons.

At the same time, this is an interesting subject, as it allows the researcher to try to peek behind the curtain of the "normal" world and notice life that persevered against all odds in ordinary places such as a forest, behind a double wall, or in ruins of a torn down building. I believe that researching the Shoah through analysis of everyday experience of people who were trying to at least partially recreate their former life in all kinds of places is a fresh and fascinating approach. It fits into modern tendencies present in sociology making us observe not only big social processes, but also be inclined to assume "micro" perspective. Through observation of everyday life, little things, phenomena, interactions and objects that were previously disregarded in descriptions for being not important enough, we arrive at a completely different perspective. Different does not necessarily mean better, but perhaps just as valuable; it is certainly enriching us with knowledge, allowing for deeper empathy and understanding of some social phenomena that previously defied cognition.

This trend in sociology is often called even a change of the research paradigm. It was followed, for example, by Piotr Sztompka and Małgorzata Bogunia-Borowska, the editors of an anthology of texts by distinguished sociologists from around the world ${ }^{9}$. In their theoretical introduction, they mention the classics: Georg Simmel, the creator of symbolic interactionism, and Norbert Elias, the creator of ethnomethodology. Thus, they present how much we can gain if we assume this new

9 Socjologia codzienności [Sociology of Everyday Life], eds. P. Sztompka, M. BoguniaBorowska, Cracow 2008. 
paradigm. Piotr Sztompka wrote the following on this subject in an abstract to his paper presented on the $13^{\text {th }}$ Sociological Convention: "Sociological theory has a historical character [...], it is a reflection of a variable state of a society, and this is why ways and means of theorizing sociology constantly change. [...] Attempts to create sociological theory in an unprecedented way, looking for mechanisms and regularities not outside the ongoing social life, in verified 'social facts' - structures, culture, but inside episodes of everyday life of people, social praxis, that one final reality of human world, are becoming richer and more interesting" ${ }^{10}$. These premises can be seen in relatively new, but now already classical works of Polish researchers of the Shoah. Books describing everyday life of the Warsaw Ghetto can serve as an example here ${ }^{11}$. I am also assuming this perspective, because I believe that both the subject and character of sources available (personal documents) make it the most suitable and the most cognitively useful.

A similar, highly inspiring approach has emerged in the last few decades in historical sciences, where the scientists are more often - to use a vivid image trying to recreate civilian life in villages at home front instead of describing troop movements and big battle strategies. Among the distinguished representatives of this approach, there are authors from the French school of historiography, including co-editors of multi-volume A History of Private Life ${ }^{12}$, Philippe Ariès and Georges Duby, as well as the historian Jean Delumeau.

Państwowy Instytut Wydawniczy [State Publishing Institute - PIW] published such history books in its Everyday Life series. There are a few works assuming such a perspective and connected with the Second World War ${ }^{13}$. Historiography

10 P. Sztompka, Nowe formy życia społecznego a nowy kształt teorii socjologicznej [New forms of social life and the new shape of sociological theory], 2007, http://www.zjazdpts. uz.zgora.pl/ab_okraglystol.html.

11 B. Engelking, Zagłada i pamięć. Doświadczenie Holocaustu i jego konsekwencji opisane na podstawie relacji autobiograficznych [Holocaust and Memory. The Experience of the Holocaust and Its Consequences: An Investigation Based on Personal Narratives], Warsaw 1994; her, “Czas przestat dla mnie istnieć...” Analiza doświadczenia czasu $w$ sytuacji ostatecznej ["Time Stopped for me..." an Analysis of Time in the Ultimate Situation], Warsaw 1996; B. Engelking, J. Leociak, Getto warszawskie. Przewodnik po nieistniejacym mieście [The Warsaw Ghetto. A Guide to a Non-Existent City], Warsaw 2001.

12 A History of Private Life, eds. P. Ariès, G. Duby, M. Perrot, A. Prost, P. Veyne, G. Vincent, vols. 1-5, Cambridge 1987.

13 T. Szarota, Okupowanej Warszawy dzień powszedni. Studium historyczne [Everyday Life in Occupied Poland. Historical Study], Warsaw 1988; Życie codzienne w stolicach okupowanej Europy. Szkice historyczne. Kronika wydarzeń [Everyday Life in Capitals of Occupied Europe. Historical Drafts. Chronicle], Warsaw 1995; S. Lewandowska, 
even distinguishes a notion of microhistory ${ }^{14}$, with the French historians Emmanuel Le Roy Ladurie and Carlo Ginzburg considered to be its main representatives. Their works mostly deal with distant centuries; meanwhile the historians researching most recent history are keen on employing advances of oral history. I write about that notion in critique of the sources.

For me the answer to "why hiding places?" is closely connected with the answer to "why space"? The term "hiding place" itself means a certain place (as I write later in Definitions). A place becomes a hideout when it becomes occupied for that reason by a person in need of shelter. But the properties making a place a possible hideout belong to a spatial order - location, borders, size, construction, structure. I believe the space to be the basic category describing and determining human world, and yet it is rarely used in sociological world. Analysis of a social phenomenon through the lens of the space which determines that phenomenon, being its background, stage, and at the same time its indispensable element, seemed to me a fascinating and completely new way of talking about the Shoah. The only work known to me describing experience of the Shoah through the prism of a comparative category (time) was "Time Stopped for me..." an Analysis of Time in the Ultimate Situation by Barbara Engelking.

I was therefore intrigued by the challenge of approaching the issue of hiding places through the category of space, as this is an impalpable category, which is non-obvious despite its universality. The problem I had to face is the simultaneous scarcity and abundance of theories connected with sociological understanding of space. Since Emil Durkheim, through Chicago school, to Yi-Fu Tuan's humanistic geography, proxemics of Edward T. Hall and environmental psychology, there were many fragmentary theories attempting to describe mechanisms governing human life in space. However, those theories turn out to be dispersed, often contradictory, and only a small number of them could apply to the specific phenomenon of wartime hiding places. I write more about useful theories of space in State of Research and Literature part of the Introduction. To complement the description and analysis of the phenomenon I base on them, I am also using other sociological categories, such as marginalization and homelessness (Chapter 4).

Życie codzienne Wilna $w$ latach II wojny światowej [Everyday Life of Vilnius during World War II], Warsaw 2001; J.K.M. Hanson, Nadludzkiej poddani próbie. Ludność cywilna Warszawy w powstaniu 1944 r. [Put to Inhuman Test. Warsaw's Civilians in 1944 Uprising], Warsaw 2004.

14 Historia społeczna, historia codzienności, mikrohistoria [Social History, Everyday Life History, Microhistory], ed. W. Schulze, Warsaw 1996; E. Domańska, Mikrohistorie. Spotkania w międzyświatach [Microhistories. Inter-worlds' Encounters], Poznań 1999. 


\section{Definitions}

The research problem of "space of Jewish hiding places in occupied Poland" requires clarification and presentation of biding definitions.

A Polish language dictionary presents the following definition of "a hiding place": "a place of hiding something safely; place where somebody hides, hideout, stash, shelter"15. Verb "to cover" means: "to be in hideout, to hide in order not to be seen; look for shelter, retreat from a dangerous ore uncomfortable place"16, while "to hide something" means: "1. Hide, place in a covered, invisible place, lock something up; 2. Hide from sight" and "to hide oneself": "1. Hide; 2. Find shelter, a hiding place, remove oneself from a dangerous area"17. After searching for cognitively useful meanings in those formulations, I define "a hiding place" as a place that is inherently safer than the outside world, a place where a human being is invisible for people threatening him or her. Hiding is an experience as old as the humankind. Development of human civilization caused primitive shelters (caves, caverns, huts) to transform into homes, thereby at some point in history it was no longer necessary to look for shelter from wild animals or dangerous atmospheric conditions. Yet in societies there were always conflicts arising and disturbing the previous order, driving people out of their homes and causing certain groups not to be allowed to be on a particular territory. In fear for their lives people would look for hiding places: running away from armies, stern authorities or angry mobs. During the Second World War the large scale and long temporal scope of this phenomenon are notable (people stayed in hiding even for a few years).

I would like to stress that the definition of a Jewish hiding place during the Second World War have assumed has a broader scope than the one generally present in literature. For the purpose of this book I have practically abandoned the commonly used division into the ghetto and "the Aryan side". Therefore, hiding places I describe include both shelters from displacement actions in the ghettos and hiding places used by people who have already escaped the ghettos. This way I go outside the frames of works describing the experience of hiding solely on "the Aryan side".

The main axis of the analysis shall be space and humans in space. I start from the smallest one - space of a wardrobe or a basement, located in a bigger space. Let us assume, for our purposes, that the borders of the entirety of the bigger

15 Podręczny słownik języka polskiego [Pocket Polish Language Dictionary], ed. E. Sobol, Warsaw 1996, p. 380.

16 Ibid., p. 380.

17 Ibid., p. 1070. 
space shall be the prewar borders of Poland - lands occupied by the Germans. Source material is not spread evenly, some towns (for example Warsaw) are described in a great number of texts, while we have no or very little materials on events in other regions of Poland. However, the geographic dimension of space will not prove the most important here. I do not strive to present a historical description of the situation in individual regions of the country, but a phenomenological representativeness of cases. I shall write more on the subject later in the Introduction. The human dimension and the fate of individual people will be more important. As for the temporal scope, I assume the date of creation of the first ghetto on the Polish land (in Piotrków Trybunalski) to be a cut-off date. It was October 1939. The other limiting date shall be the date of Red Army stepping in, i.e. the end of German occupation. This date is different for various regions.

Actors of the events and authors of the analyzed texts are primarily Jews who chose a hiding place as a means of survival at some point of their wartime life, regardless of their previous or later fate. Their testimonies will be the base of descriptions and analyses. We are concerned with the people who were hiding their physical existence, and not only with the fact that they were Jewish. Therefore, it is not a matter of identity, but it is a matter of the body. Erving Goffman postulated a concept of a stigma, which aptly describes the situation of Jews hiding during the war. There are - Goffman claims - two kinds of stigma. When the features stigmatizing a given person are immediately visible (skin color, bodily injury), an individual is "discredited". When those features can be hidden, disclosed or not, an individual becomes discreditable ${ }^{18}$. According to this pattern, there was a dividing line between the people who have chosen to live "on Aryan papers" and the ones who have hidden completely. People from the first group excluded themselves from the discreditable set, their lives became a struggle to not reveal the secret of their background. People from the second group knew or felt that they are discredited, therefore their only option was to fall off the face of Earth and hide their existence from the world.

Self-determination and choosing one group or the other would often not be entirely based on reason. Some people living "on Aryan papers" were characterized with "bad appearance" and perhaps they should have chosen to live in hiding. That status was changing depending on outside conditions and mental processes. It was decided by chance, temporary circumstances, a chance for specific help or physical well-being in a given moment, allowing people to take up

18 E. Goffman, Stigma. Notes on the Management of Spoiled Identity, New York 1963, pp. 41-66. 
one challenge or the other - without being fully aware of the consequences of that choice ${ }^{19}$. As a result, the group of Jews hiding "underground" is diversified in a manner that is hard to systematize according to a variety of social categories such as gender, social layer, level of assimilation.

The other actors are in the background (their voice can be only supplementary): local non-Jewish people (Poles, Lithuanians, Ukrainians or - without specifying the nationality - "locals"), but also Jews living among them under assumed identity. A separate place should be earmarked for the occupants - the Germans (and their helpers of various nationalities, just to list Ukrainian and Latvian troops). Therefore, these are everybody who took part in creating, sustaining and destroying Jewish hiding places during the Shoah.

\section{State of research and literature}

The issue of Jewish hiding places during Nazi occupation in Poland has not yet been granted a separate treatment in Polish scientific literature. In a fragmentary way, it is present in general studies on the history of the Shoah ${ }^{20}$. There are, however, works on individual aspects of the issue. The subject of hiding places in Warsaw is best described. As early as during the war Emanuel Ringelblum in his Chronicle of the Warsaw Ghetto ${ }^{21}$, written on real time basis, presented an analysis of evolution of hiding places in the ghetto and on the Aryan side over time. He has also addressed this subject in a monograph entitled Polish-Jewish

19 There was also a big group of people with a status that was hard to define. In Strategie przetrwania. Żydzi po aryjskiej stronie Warszawy (Warsaw 2004) [Strategies of Survival. Jews on the Aryan Side of Warsaw] Joanna Nalewajko-Kulikov calls that status "by the surface". Those people were leading lives which were a resultant of constantly hiding and existing "on Aryan papers". They often had forged documents, but did not count on them too much, as they were not "sure", or because of "bad appearance" they were not risking going out in the streets too often or needlessly. They kept in touch with the world, but the number of people for whom they were "visible" was usually limited to the most trusted ones.

20 T. Prekerowa, Zarys dziejów Żydów w Polsce w latach 1939-1945 [Outline of History of Jews in Poland in 1939-1945], Warsaw 1992; Akcja Reinhardt. Zagłada Żydów w Generalnym Gubernatorstwie [Reinhardt Action. Holocaust of Jews in General Government], ed. D. Libionka, Warsaw 2004.

21 E. Ringelblum, Kronika getta warszawskiego [Chronicle of the Warsaw Ghetto], Warsaw 1983. 
Relations during the Second World War22. Michał Grynberg wrote an article on bunkers and shelters in the Warsaw Ghetto and published in the "Bulletin of Jewish Historical Institute"23. The phenomenon of hiding is also mentioned by Teresa Prekerowa ${ }^{24}$. Barbara Engelking described bunkers, where masses of people would hide during the Warsaw Ghetto Uprising and after it failed ${ }^{25}$. The issue of Warsaw-based "Robinson Crusoes" is present in a valuable work of Barbara Engelking and Dariusz Libionka, Jews in the Warsaw Uprising ${ }^{26}$. Joanna Nalewajko-Kulikov generally addressed the issue of the "Aryan side" in Warsaw, describing both the group of people living in strict hiding and the ones functioning "on Aryan papers" 27 . In English, there was a work describing the situation in Warsaw $^{28}$. The situation of the countryside, small towns and rural areas is definitely less carefully analyzed. Aside from mentions in more general works, there are only two monographs. The issue of Jews from Warsaw district (excluding Warsaw) who were hiding is addressed in Małgorzata Melchior's article Escapees from Ghettos in the Province of the Warsaw District - Methods of Survival ${ }^{29}$. Aleksandra Bańkowska's master's written in 2006 in the History Department of the University of Warsaw is a valuable monograph of woodland hiding places ${ }^{30}$.

22 E. Ringelblum, Stosunki polsko-żydowskie w czasie drugiej wojny światowej. Uwagi $i$ spostrzeżenia [Polish-Jewish Relations during the Second World War. Notes and Observations], Warsaw 1988.

23 M. Grynberg, Bunkry i schrony w warszawskim getcie [Bunkers and Shelters in the Warsaw Ghetto], "Biuletyn ŻIH” [Bulletin of Jewish Historical Institute] 1989, No. 149.

24 T. Prekerowa, Konspiracyjna Rada Pomocy Żydom w Warszawie 1942-1945 [Conspiracy Council to Aid Jews in Warsaw 1942-1945], Warsaw 1982.

25 B. Engelking, J. Leociak, Getto warszawskie. Przewodnik... [The Warsaw Ghetto. A Guide...]

26 B. Engelking, D. Libionka, Żydzi w powstańczej Warszawie [Jews in the Warsaw Uprising], Warsaw 2009.

27 J. Nalewajko-Kulikov, Strategie przetrwania. Żydzi po aryjskiej stronie Warszawy [Strategies of Survival. Jews on the Aryan Side of Warsaw], Warsaw 2004.

28 G.S. Paulsson, Secret City. The Hidden Jews of Warsaw 1940-1945, New HeavenLondon 2002.

29 M. Melchior, Uciekinierzy z gett po "stronie aryjskiej" na prowincji dystryktu warszawskiego - sposoby przetrwania [Escapees from Ghettos in the Province of the Warsaw District - Methods of Survival], in: B. Engelking, J. Leociak, Prowincja noc. Życie i zagłada Żydów w dystrykcie warszawskim [Province of the Night. Life and Holocaust of the Jews in Warsaw District], ed. D. Libionka, Warsaw 2007.

30 A. Bańkowska, Las jako miejsce przetrwania Zagłady. Zjawisko ukrywania się Żydów w lasach $w$ okresie okupacji niemieckiej w latach 1941-1945 na terenie II Rzeczypospolitej 
An interesting book by Jacek Leociak, Saving. Stories of Poles and Jews ${ }^{31}$, has been recently published. The author focuses primarily on Polish-Jewish relations in the specific context of helping the hiding people.

We can ask what the reason for this state of affairs is, considering the fact that to date dozens of scientific works on the Shoah have been written in Poland and thousands worldwide. The issue of hiding somehow remains outside the scope of interest of the researchers, despite the fact that it is an important and very common experience of the time of the Shoah. I cannot present any estimates, but the sources lead me to believe that a high percentage of the Jews who happened to be in Poland during German occupation had a shorter or longer period of hiding in their biography. Therefore, this experience is as important and as worthy of being described as the ghettos and camps. The issue of the researchers avoiding the subject of hiding Jews is addressed in the introduction of Gunnar S. Paulsson's book ${ }^{32}$. Admittedly, Paulsson writes about a narrower scope of the described phenomenon than the one I propose, as he limits his focus to escapes from the Warsaw Ghetto and hiding on the Aryan side in Warsaw, but his arguments seem to be worth citing.

Paulsson calls the above-mentioned gap "terra incognita in research of the Shoah". He starts his deliberations with invoking the classics - Raul Hilberg and Hannah Arendt. In his opus magnum, The Destruction of European Jews ${ }^{33}$, Raul Hilberg analyzes attitudes of victims toward the Shoah, creating a scale thereof from complete passivity, through paralysis, evasion, mitigation, to resistance. In so doing he postulates that lack of resistance was the most common attitude among the Jews. In contrast, Hannah Arendt in her groundbreaking Eichmann in Jerusalem ${ }^{34}$ point-blank accuses Jews (especially Judenrats) of assisting the Germans in extermination. Both those opinions provoked a wide spread debate in which Israel historians ${ }^{35}$ in particular opposed such unjust presentation of the issue and countered the accusations of passivity with examples of active Jewish resistance: uprisings in ghettos and camps or operations of Jewish guerilla. Thus, Paulsson notes, in the discourse on Jewish attitudes toward the Shoah the center

Polskiej [Forest as a Place of Surviving the Shoah. The Phenomenon of Jews Hiding in Forests during German Occupation in 1941-1945 in Second Polish Republic], Warsaw 2006.

31 J. Leociak, Ratowanie. Opowieści Polaków i Żydów [Saving. Stories of Poles and Jews], Cracow 2010.

32 G. Paulsson, Secret City...; see. J. Nalewajko-Kulikov, Strategies...

33 R. Hilberg, The Destruction of European Jews, Chicago 1961.

34 H. Arendt, Eichmann in Jerusalem. A Report on the Banality of Evil, New York 1963.

35 Inter alia, Reuben Ainsztein, Yehuda Baker, Isaiah Trunk. 
of gravity has shifted toward the dispute between the extremes, and "the third from Hilberg's categories - evasion, i.e. escape and hiding attempt disappeared off the network"36.

Therefore, Paulsson explains the absence of literature on the subject by pointing to "psychological and political causes" ${ }^{37}$. He notices that the attitude of escapees was stigmatized as undignified and treacherous toward the ones who stayed in the ghettos to die (also in combat). Aside from that, drawing attention to the "third way" disrupts a clear dichotomy: armed resistance or passively surrendering to die. Paulsson makes a whole list of "uncomfortable questions" that one should ask oneself for example when researching the history of the Warsaw Ghetto Uprising. He is also exposing the opinion that a chance for survival on the Aryan side was "negligible", therefore the escapes and hiding remain a marginal phenomenon. Concluding Paulsson's deliberations we should stress his efforts to restore in the minds of researchers of the Shoah an appropriate status of the issue of escaping ghettos and hiding and we should recognize that he strives to at least partially fill the described void in the scientific discourse with his book. I will, however, add that Paulsson wrote only twenty pages (a part of Secret City chapter entitled Apartments for Jews: Looking for Dens) in description and analysis of the space of hiding places - the aspect key for me - while trying to synthetically describe the complex issue of "the Aryan side" in Warsaw.

In 2011, two extremely worthwhile works were published. They describe the issue of hiding in which I am interested, though from a different perspective. They are both connected with the period now called "the third stage of the Holocaust", i.e. the period of liquidations of the ghettos, when the Jews who survived till that moment were looking for shelter amongst their non-Jewish neighbors. Those two works are Such a Beautiful Sunny Day... - Jews Seeking Refuge in the Polish Countryside, 1942-1945 by Barbara Engelking and Hunt for the Jews: Betrayal and Murder in German-Occupied Poland by Jan Grabowski, issued by The Polish Center for Holocaust Research of the Institute of Philosophy and Sociology of the Polish Academy of Sciences. The researchers focus on describing the fate of Jews in Polish countryside, primarily presenting the scale of negative phenomena, acts of violence, turning Jews in to the occupants and murders. They do so by analyzing e.g. a pioneer source of so-called sierpniówki [August decrees translator's note], i.e. postwar records of trials connected with denunciation and murders on Jews.

36 G. Paulsson, Secret City..., p. 34.

37 Ibid., p. 37. 
I have to stress that even though the subject of the book is just a piece of the Jewish experience of the Shoah, I try to keep the wide historical context of the subject in mind. Despite the fact that the literature still lacks works devoted solely to the hiding places, there are dozens of books in my bibliography that describe the history of the Holocaust very broadly (aside from the ones mentioned above they include, among others: M. Fuks, $Z$ dziejów Wielkiej Katastrofy narodu żydowskiego [The History of the Great Catastrophe of the Jewish Nation], Poznań 1999; M. Gilbert, Holocaust, Warsaw 2002; H. Haumann, Historia Żydów $w$ Europie Srodkowej $i$ Wschodniej [A History of East European Jews], Warsaw 2000; R. Hilberg, The Destruction of European Jews, Chicago 1961; R. Hilberg, Sprawcy, ofiary, świadkowie [Perpetrators Victims Bystanders], Warsaw 2007; K. Iranek-Osmecki, Kto ratuje jedno życie... Polacy i Żydzi 1939-1945 [Who Saves one Life...], London 1968; K. Jasiewicz, Świat NIEpożegnany. Żydzi na dawnych ziemiach wschodnich Rzeczypospolitej w XVIII-XX wieku [Unfarewelled world. Jews in the former East Lands of the Republic XVIII-XX], Warsaw-London 2004; D. Stola, Nadzieja i zagłada. Ignacy Schwarzbart - żydowski przedstawiciel w Radzie Narodowej RP (1940-1945) [Hope and Holocaust. Ignacy Schwarzbart Jewish representative on the Polish National Council (1940-1945)], Warsaw 1995; A. Żbikowski, U genezy Jedwabnego. Żydzi na Kresach Pótnocno-Wschodnich II Rzeczypospolitej. Wrzesień 1939-lipiec 1941 [The Genesis of Jedwabne. Jews in the Northern-Eastern Borderlands of the Second Republic of Poland: September 1939 - July 1941], Warsaw 2006) or presenting wartime fate of local communities in Poland (including A. Biberstein, Zagłada Żydów w Krakowie [Holocaust in Cracow], Cracow 2001; A. Bikont, Myz Jedwabnego [Us from Jedwabne], Warsaw 2004; W. Boczoń, Żydzi gorliccy [Gorlice Jews], Gorlice 1998; R. Caputa, I. Jeziorski, Okruchy pamięci. Z dziejów Żydów na Żywiecczyźnie [Flecks of Memory. History of Jews in Żywiecczyzna], Cracow 2000; A. Chomet, Zagłada tarnowskich Żydów [Holocaust in Tarnów], in: Holocaust of Tarnów Jews, ed. A. Pietrzykowa, S. Potępa, Tarnów 1990; J. Grabowski, Ja tego Żyda znam! Szantażowanie Żydów w Warszawie 1939-1943 [I Don't Know that Jew! Blackmailing Jews in Warsaw 1939-1943], Warsaw 2004; M. Grynberg, Żydzi w rejencji ciechanowskiej 1939-1942 [Jews from Ciechanów Regierungsbezirk 1939-1942], Warsaw 1984; I. Gutman, Żydzi warszawscy 1939-1945. Getto - podziemie - walka [The Jews of Warsaw, 1939-1943: Ghetto, Underground, Revolt], Warsaw 1993; E. Jones, Żydzi Lwowa w okresie okupacji 1939-1945 [The Jews of Lviv during the 19391945 Occupation], Łódź 1999; K. Kocjan, Zagłada olkuskich Żydów [Holocaust of Olkusz Jews], Olkusz 2002; F. Kotula, Losy Żydów rzeszowskich 1939-1944 [Fate 
of Rzeszow Jews 1939-1944], Rzezów 1999; Byli wśród nas. Żydzi we Włocławku oraz na Kujawach Wschodnich i $w$ Ziemi Dobrzyńskiej [They Were among Us. Jews in Włocławek and Eastern Kujawy and Dobrzyń Land], ed. M. Krajewski, Włocławek 2001; Z. Pakuła, Siwe kamienie. Wielkopolscy Żydzi [Grey Stones. Jews in Greater Poland], Poznań 1998; A. Potocki, Bieszczadzkie losy [Fates in Bieszczady], Rzeszów-Krosno 2000; A. Potocki, Żydzi rymanowscy [The Jews of Rymanów], Krosno 2000; Żydzi w Lublinie [Jews in Lublin], ed. T. Radzik, Lublin 1995; K. Urbański, Holocaust of the Jews in Kielce 1939-1945, Kielce 1994; K. Urbański, Zagłada Żydów w dystrykcie radomskim [Holocaust of the Jews in Radomski District], Cracow 2004; K. Zimmerer, Zamordowany świat. Losy Żydów $w$ Krakowie 1939-1945 [Murdered World. The fate of Krakow's Jews 1939-1945], Cracow 2004). In realizing the social mechanisms present in Poland during the Shoah, the following books proved to be helpful: books by Jan Tomasz Gross (Neighbors, Sejny 2000; Upiorna dekada [Ghastly Decade], Kraków 2001; Wokót "Sąsiadów". Polemiki i wyjaśnienia [Around "Neighbors". Arguments and Explanations], Sejny 2003; Fear. Antisemitism in Poland after Auschwitz. An Essay in Historical Interpretation, New York 2006; Strach. Antysemityzm w Polsce tuż po wojnie. Historia moralnej zapaści [Fear: Anti-Semitism in Poland After Auschwitz. An Essay in Historical Interpretation], Cracow 2008), prose by Henryk Grynberg (Dziedzictwo [Heritage], London 1993; Drohobycz, Drohobycz, Warsaw 1997; Ojczyzna [Fatherland], Warsaw 1999; Memorbuch, Warszawa 2000; Żydowska wojna. Zwycięstwo [The Jewish War and The Victory], Wołowiec 2001; Prawda nieartystyczna [The Non-Artistic Truth], Wołowiec 2002) and many works of fictions listed in the bibliography.

With regard to the theoretical base on space in social sciences, the literature on the subject is copious.

In its colloquial understanding, the space is inevitably connected with time. Jacek Kaczmarek aptly notices that in history of science "there were alternating periods of dominance of time and space in explaining natural and social phenomena" 38 , but the time has been and still is preferred by researchers. There is even a "gradual marginalization of spatial relations" ${ }^{39}$. Comparing entries in

38 J. Kaczmarek, Podejście geobiograficzne w geografii społecznej. Zarys teorii i podstawy metodyczne [Geobiographical Approach in Social Geography. Outline of the Theory and Basic Methodology], Łódź 2005, p. 8.

39 Ibid., p. 8. 
various encyclopedias and lexicons, Kaczmarek concludes that the notion of time is studied a lot more carefully and exhaustingly, for instance there are disproportions in amounts of space devoted to time and space. Space is a category which is a lot more abstract, it is more elusive and at the same time in a way less interesting. It is seen in conversational language as well. "In linguistic approach the space has a form of everyday element of human life and is trivialized for that reason" ${ }^{\prime \prime}$. Yet, the author notes that in the last few years there was a renaissance of interest in space, he even calls it "spatio-centrism". It seems that space is once again perceived as an attractive and useful category, which allows us to see social phenomena from a different, more surprising perspective.

How should we understand space? For scientists from various disciplines it is an exceptionally universal notion, hence there is a multitude of definitions. Kaczmarek writes: "uncovering new types of space and transcending research areas of various scientific disciplines leads us to draw two basic conclusions:

a) space is one of the basic notions in human thought; it is 'a seed' that grows into reflection about recognition and understanding of the world around [...];

b) reflection on space cannot apply only to one universal definition of space"41.

Bohdan Jałowiecki presents an array of fundamental meanings: "Space is an abstract idea (mathematical), a property of matter (physical). Natural environment developed in a certain way through evolution (natural, geographical), finally it is a human creation, which is anthropogenic, cultural and social, thus created by individuals, groups and collectives (social, cultural)"42. Only that last characteristic of space allows us to describe the phenomenon of a hiding place. Currently in the scientific world there are many related disciplines and sub-disciplines. We should take advantage of their findings when addressing this issue. Anthropology and sociology of space, humanistic geography, social ecology, environmental psychology... all those disciplines emerged thanks to changing the status of space and human beings therein. Development of those disciplines was possible thanks to discarding absolutistic concept of space, where "human being [was treated] as a mass subject to certain regularities in an environment" ${ }^{\text {"3 }}$.

40 Ibid., p. 9.

41 Ibid., p. 17.

42 B. Jałowiecki, M. Szczepański, Miasto i przestrzeń w perspektywie socjologicznej [City and Space in Sociological Perspective], Warsaw 2001, p. 301.

43 Humanistyczne oblicze miasta [Humanistic Face of the City], ed. D. Jędrzejczyk, Warsaw 2003, p. 79. 
An approach referred to as "humanistic" shifts the center of gravity to humans and their actions in space, presenting them as creators of said space and being interested in meanings they ascribe to space. To simplify, let us assume that sociology describes a process of social production of space, and anthropology allows for a semiotic approach - searching for and deciphering cultural meanings. There is also the study of human behavior in space and sensual reception thereof. This is the scope of work of ethnology, proxemics, ecological (environmental) psychology and psychology of architecture, which is a part thereof.

The approach of environmental psychology seems to be the most helpful in describing the experience of a hiding place. This scientific discipline studies relations and dependencies between a human and physical and social environment: material, geographical, spatial, architectural, virtual, social, cultural, ecological and psychological. J. Krzysztof Lenartowicz presents three groups of its interests: "1) influence of physico-spatial modalities of an environment (space, shape, sound) on psyche and behavior; 2) factors of physio-social environment in the context of changes in self-esteem, growing up, sense of development, sense of identity, sense of controlling the environment and freedom of action; 3) application of scientific psychological knowledge about functioning of human beings in an environment to practice connected with health care, human work" ${ }^{\prime 4}$. Psychology of architecture is considered to be a sub-discipline of environmental psychology. It applies to the influence of environment created by people, i.e. organized space, on humans. Authors from the middle of $20^{\text {th }}$ century are considered to be precursors of this science. New ideas emerged in books by Gaston Bachelard, Edward Hall, Kevin Lynch, Robert Sommer and Robert Venturi ${ }^{45}$. Behavioral geography is related to environmental psychology ${ }^{46}$.

Environmental psychologists are primarily interested in relations of human and his designed environment, i.e. environment created by people. The area of research of environmental psychology dealing with influence of "physio-spatial

44 J.K. Lenartowicz, Słownik psychologii architektury [Dictionary of Psychology of Architecture], Cracow 2005, p. 92.

45 G. Bachelard, La poétique de l'espace, Paris 1957 (anonymous translation http://www. domowat-mosfera.art.pl/opow0.htm); E.T. Hall, The Silent Language, New York 1959; The Hidden Dimension, New York 1990; K. Lynch, The Image of the City, Cambridge 1960; R. Sommer, Personal Space: The Behavioral Basis of Design, Englewood CliffsNew Jersey 1969; R. Venturi, Complexity and Contradiction in Architecture, New York 1966.

46 The most important authors include John Robert Gold, Lawrence M. Ward, James A. Russel, Robert M. Kitchin, Mark Blades, Reginald G. Golledge. 
modalities of an environment such as space, shape, and sound"47 on behavior, psyche and identity of people is especially valuable for me. This is a fairly new branch of science, based on an interdisciplinary approach to the problem and using methodology and traditions of other sciences. One of the basic issues of environmental psychology is a question, whether this human-environment relation can be described only on a level of an individual, or can it be transferred to the level of a group or society. Experience of few decades of research by environmental psychologists shows that even though there are extraordinary situations causing unique reactions of individuals, similar conditions often influence whole groups of people in similar manner. This is why environmental psychology has worked out methods of analyzing behavior of individuals in a social context.

To list the most valuable theoretical works, I have to say that synthetic works ${ }^{48}$ proved to be particularly helpful, along with works from a discipline seemingly distant from sociology - psychology of architecture ${ }^{49}$. Conversely, I have not yet encountered any works on the Shoah that would approach the subject from the perspective of space. Therefore, I was inspired by works describing completely different areas of social (and historical) reality, for example by book by Mikołaj Madurowicz entitled Sfera sacrum w przestrzeni miejskiej Warszawy [Sacrum in Urban Space of Warsaw] ${ }^{50}$ or by an exceptional work by Grażyna Ewa Karpińska entitled Miejsce wyodrębnione ze świata. Przykład tódzkich kamienic

47 A. Bańka, Społeczna psychologia środowiskowa [Social Environmental Psychology], Warsaw 2002, p. 26.

48 Ibid., B. Jałowiecki, M. Szczepański, Miasto i przestrzeń... [City and Space...]; Humanistyczne oblicze miasta... [Humanistic Face...]; J. Kaczmarek, Podejście geobiograficzne... [Geobiographical...]; Przestrzeń we współczesnej nauce [Space in Contemporary Science], eds. W.A. Kamiński, G. Nowak, S. Symotiuk, Zamość 2003; Y.F. Tuan, Przestrzeń i miejsce [Space and Place], Warsaw 1988.

49 W. Czarnecki, Podstawy urbanistyki [Basic Urbanism], Białystok 2002; Bioarchitektura zagadnienia społeczne [Bioarchitecture - Social Issues], ed. M. Czyński, Szczecin 1992; M. Czyński, Architektura w przestrzeni ludzkich zachowań [Architecture in Space of Human Behavior], Szczecin 2006; J. Gądecki, Architektura i tożsamość. Rzecz o antropologii architektury [Architecture and Identity. On Anthropology of Architecture], Warsaw 2005; J.K. Lenartowicz, Słownik... [Dictionary...], Cracow 2005; J.A. Włodarczyk, Oblicza architektury. Próby [Faces of Architecture. Attempts], Białystok 2000; Żyć znaczy mieszkać. Dom mieszkalny na granicy stuleci [To Live Is to Dwell. Residential Building on Turn of the Centuries], Tychy 2004.

50 M. Madurowicz, Sfera sacrum w przestrzeni miejskiej Warszawy [Sacrum in Urban Space of Warsaw], Warsaw 2002. 
czynszowych [Space Isolated from the World. Example of Tenement Townhouses in $t o ́ d z]^{51}$. This work is written from the perspective of sociology of everyday life, which is close to me.

\section{Research questions, structure}

I do not aim to present an exhaustive description of Jewish hiding places on the whole territory that was once within the limits of prewar Poland. This is rather a task for a historian, who would study in detail the complete existing and available corpus of sources, not limiting him or herself to looking at the phenomenon of a hiding place from one perspective. After designating the space as my key category to determine the description, I was rather striving to outline some characteristic phenomena and to trace social mechanisms functioning in the period I am describing and connected with the phenomenon of Jewish hiding places. I was also aiming at anthropological interpretation of a hideout as a place with a particular meaning.

I have chosen a particular, not completely obvious perspective to analyze and interpret the social phenomenon I am describing. As a consequence, I have achieved the structure of this text as it is. It does not fall into pattern of "presentation of theoretical approaches - analysis of the materials - conclusions", it is more complex. This came about primarily because it was not possible to find one sociological theory that would allow optimal and harmonized elaboration on the texts I have collected. As I have shown above, in State of research and literature segment, sociology of space (and related disciplines, such as environmental psychology or psychology of architecture), despite abundance of theoretical approaches, is not allowing for comprehensive and complete analysis of a phenomenon so complex (and placed in such a specific context) as Jewish hiding places. One of the main issues was the discrepancy between research practices of this area I know and my intention. Studies of sociology of space I know are mostly related to contemporary times, especially the time of peace, when social reality is completely different from the situation of wartime. Sociologists of space often assume territorial boundaries, conducting their research e.g. in one city $^{52}$. On account of available sources, I did not want to assume the territorial

51 G.E. Karpińska, Miejsce wyodrębnione ze świata. Przykład łódzkich kamienic czynszowych [Space Isolated from the World. Example of Tenement Townhouses in Łódź], Łódź 2000 (Łódzkie Studia Etnograficzne, t. XXXVIII).

52 See Warszawiacy o sobie i swoim mieście [Citizens of Warsaw on Themselves and Their City], eds. J. Grzelak, T. Zarycki, Warsaw 2004. 
perspective, as I wanted to include to the analysis various interesting testimonies I knew from parts of occupied Poland which were distant from each other, which would be impossible when limited to a narrower territory. I have also assumed universal main features of hiding places, regardless of their geographical location. The most effective research method of sociology of space is conducting interviews and surveys, especially on a significant sample. For obvious reasons, I could not follow that pattern; I write more on the issue of sample and interviews in Methodology.

Wishing to approach the issue from various perspectives, at the same time still using the category of space as my primary one, I have decided to present my analyses in the following arrangement.

Chapter 1 is entitled Scope of the analysis. Attempted typology of hiding places according to objective criteria. In this chapter, I present a typology of Jewish hiding places formulated for the purposes of this book. The chapter is to outline the scope of analysis conducted in the later part of the book. I wanted to present possibly widest spectrum of hiding places we know about from the available sources, at the same time proposing a limited number of the types. I assume objective criteria to describe individual types of hiding places. I propose the following division:

- Depending time spent in a hiding place: temporary and long-term;

- Depending on presence or lack of outside help: independent and assisted hiding places. Among the later ones I describe hiding places "under one roof" and "at the distance";

- Depending on a topographic location of a hiding place I distinguish the ones in big and small cities, in the countryside and on "no-man's land"; among the later ones there are two separate categories of woodland hiding places and hiding places in "excluded areas" (concentration camps, labor camps, death camps, places of execution);

- Depending on number of people hiding therein: solitary and collective hiding places.

A separate category is "wandering - looking for a hiding place". This way I was also able to include a dynamic situation, essentially different from particular types of hiding places in a static approach to my systematization. To present each of the categories above, I have selected the most characteristic examples, thereby presenting the complexity of the phenomenon I analyze in the following chapters.

Chapter 2 is entitled Hiding place as a space. Perspective of social and individual experience. It is divided into two parts. 
The first part contains an analysis of the phenomenon of hiding places as a social space in various aspects of that notion. In that part I use sociological approach to the category of space, which is essential to the whole work. I employ various sociological theories and attempt to shine light on the phenomenon of space of a hiding place from various sides. By doing so, I confront various questions with no unambiguous answers. I wonder what a hiding place has changed in social space by its existence. Are we able to recreate quality and character of those changes, having the following points of view at our disposal - of the Jews, for whom a hiding place is their whole world, and the Poles, who either do not mention it, or want to track it down, or support it and thus it is something inconveniencing them? What has the existence of a hiding place changed in their perception of reality? To answer those questions, I compare Jewish testimonies and fragments of Polish memoirs or journals. For the counterpoint, I use the "perspective of an executioner", analyzing a report by Friedrich Katzmann, co-orchestrator of operation "Reinhardt", SS and police Commander in Galicia district.

In the second part of the chapter, I attempt to describe an individual experience of a specific space of a hiding place, drawing on perspective of environmental psychology. I identify spatial perception and environmental stress to be the two main elements of this experience. A subchapter entitled Perception of space is filled with a description of experiencing the space of a hiding place with senses. It was compiled based on numerous testimonies. I successively present how people were able to pick up visual, auditory, olfactory and tactile sensations. In Personal space and environmental stress part I endeavor to answer a question of what influence on the level of stress of the hiding people the density (and its subjective perception - crowding) had, along with violation of personal space and adverse environmental conditions connected thereto. I have entitled the last subchapter of this part Body in a hiding place; in this part, I have attempted to summarize the phenomenon. I conclude that biological imperative is the most basic existential experience in the conditions of a hiding place. It determined social behaviors and individual experiences.

I realize that all the answers to my research questions have a hypothetical character, it is impossible to classify them in any fashion. Therefore, I am leaning toward such a research attitude in which the perspective of the authors of the testimonies is the most important. Assuming that the wartime reality is never going to fully yield to our cognition, we have to approach its description as a unique phenomenon. Each time we treat the testimony we read as a voice of an individual person who - when writing down his or her experiences - wanted to share them with others, but was probably aware that those efforts were in vain. Thus, when 
analyzing the literature of personal document of the time of the Shoah, we have to shift the center of gravity to an attempt to go over the discourse reflecting the authors' perception. I devote Chapter 3 to just that. It is entitled Meanings in a space of a hiding place. First, in the subchapter entitled Space of a hiding place - in search for meanings, I use classical categories we know from anthropology of culture: center and peripheries, oppositions of directions, sacred and profane, availability and boundaries. In the following subchapter, Symbolical spaces of hiding places, archetypes and meanings encapsulated in texts, I once again endeavor to look at a hiding place from the inside. People hiding there are themselves using some recurring metaphors, fitting hiding places into models and structures functioning in society and culture. I analyze those metaphors, attempting to match various keys to interpretation to the stories about hiding places. I want to ascertain what the space of a hiding place meant to the hiding people. A desert island, where they felt like Robinson Crusoe? Noah's ark, safely transporting them through a troubled sea? A burrow, where they felt like a hunted animal who stopped there for a while? A besieged fortress, from which they could finally strike the enemy? A grave, where they felt like buried alive? Each of those concepts can be found in a form of culture topoi of our civilization. I would like to see if and in what form are they present in stories about hiding. The third subchapter is devoted to a lot more capacious and more universal metaphor of a prison, through which we can describe virtually any locked hiding place.

Chapter 4 is on the last of the great topoi, which, due to its complexity and gravity, deserves an individual treatment. It is the motive of a home. Defining a hiding place as a permanent place of residence for a determined period makes us ponder the issue of home and the way it functions. Non-Jews have their homes, Jews only have hiding places - can we analyze this state of affairs as a subsequent element of the hiding Jews' degradation as people? When studying this issue, I used sociological categories of exclusion, marginalization and homelessness. That last category in particular seems to aptly describe the wartime fates of Polish Jews. Thus, this chapter is structured as follows: in the subchapter Home, I briefly explain the notion of a home and invoke the beginning of architecture and modern theories of designing, setting out to answer the question of how is a home created. In the next subchapter, Homelessness - lack of home as a threat to safety and life, I cite the basic terms and definitions connected with categories of homelessness and marginalization. Next, I use them to describe the situation of Jews who were stripped of the roofs over their heads during the war (War as a cause of homelessness; Things and homes in hands of the neighbors). I call the situation of homelessness a crisis. In consequence, the process of building a hiding 
place is a way of dealing with a difficult situation. This thread is developed in the third subchapter, Response to a crisis - hiding place as a home. There I try to determine what kind of a hiding place could take over the function of a home and to what extent. I also focus on the process of making a hiding place. Based on the analysis of texts, it appears that in many cases an activity culminating in at least partially regaining a home (as a hiding place created or furnished by one's own hands) leads the builders to regain their compromised sense of causality.

Therefore, starting with an objective typology of the phenomenon, through description of its place in social and individual experience of a human being, and an attempt to recreate the meanings it is ascribed, I discover the key function of hiding places (aside from their basic function - saving lives) in the Jews' struggle to overcome the social status that was imposed on them.

\section{Critique of the sources}

Nearly all the authors writing about the Holocaust discuss the issue of the sources in the introductions to their works ${ }^{53}$. Alina Skibińska has even published a work entirely devoted to source materials for the Shoah research ${ }^{54}$.

In the introduction, the author states that by definition she does not work on critique of the sources, yet there are numerous valuable notes on this subject in her work. Two important issues connected with biographical approach seem inevitable, but one should be aware of them and appropriately adjust conclusions

53 See B. Engelking, Zagłada... [Holocaust...]; N. Tec, Diaries and Oral History. Reflections on Methodological Issues in Holocaust Research, in: Holocaust Chronicles: Individualizing the Holocaust Throught Diaries and Other Contemporaneous Personal Accounts, prepared by R.M. Shapiro, New York 1999; M. Melchior, Zagłada a tożsamość... [The Holocaust and Identity...]; eadem, Zagłada i stosunki polsko-żydowskie w opracowaniach socjologicznych [Holocaust and Polish-Jewish Relations in Sociological Studies], “Zagłada Żydów” [Holocaust] 2005, No. 1; J. Leociak, Literatura dokumentu osobistego jako źródło do badań nad zagłada Żydów. Rekonesans metodologiczny [Literature of Personal Document as a Source of Studies of the Shoah. Methodological Reconnaissance], “Zagłada Żydów” 2005, No. 1; A. Żbikowski, U genezy Jedwabnego. Żydzi na Kresach Pótnocno-Wschodnich II Rzeczypospolitej. Wrzesień 1939-lipiec 1941 [The Genesis of Jedwabne. Jews in the Northern-Eastern Borderlands of the Second Republic of Poland: September 1939-July 1941], Warsaw 2006.

54 A. Skibińska, Źrodła do badań nad zagładą Żydów na okupowanych ziemiach polskich. Przewodnik archiwalno-bibliograficzny [Sources for Research on the Shoah on the Occupied Territory of Poland. Archive-bibliographical Guide], Warsaw 2007. 
drawn on research. The first issue is the representativeness of the sources, and the second issue is credibility.

We should note that in the studies on the Shoah based on personal documents it is impossible to achieve any representativeness of the sample. The testimonies available are a voice of only few witnesses and actors of those events. During the war only a small group of people would write any texts. We do not know how many journals and letters went missing. In turn, all the memoirs and postwar accounts are created by the survivors. We have to also note that not all the survivors have approached institutions with their accounts or have undertaken to write down their experiences themselves. When it comes to other induced sources, i.e. for example contemporary in-depth interviews in the spirit of oral history, we can only reach the few people who are still alive, who can be identified as survivors, and who additionally want to talk about this issue.

All those factors are significantly narrowing the sample, but also make it impossible to characterize it against the backdrop of the whole Jewish community who experienced the Shoah in Poland. We are also unable to determine what the sources we cannot study could have been like. Aside from obvious conclusions, which are also not very helpful from the cognitive standpoint (we assume that memoirs and journals were written by more educated people - yet we do have oral accounts of uneducated people at our disposal), there is one assertion left - all the quantitative research will always be burdened by substantial error and can be only treated as an estimate. Thus, Małgorzata Melchior proposes to differentiate the cases we select for the sample as far as possible: from one hand by choosing the testimonies of people with diverse qualities, even if they are only individual cases; and from the other hand by thematic differentiation. "If the cases considered in the study do not seem to represent all the important categories or issues, variants of the situation, types of experience of ways of understanding the individual experiences, we should enrich such a sample with cases that would reflect other, previously absent categories and issues"55.

Above all, however, such "non-representativeness of the sample" has a deeper meaning, which should be discovered and considered by every researcher of the Shoah. It is the inability to get to the bottom to the experience of the Holocaust; neither of whole communities, nor even individuals. It is so as - to cite Jan T. Gross - all the testimonies are works of the living: "After all, everything we know on this subject - by the sole fact that it was told - is not a representative sample of Jewish fate. Those are all stories [...] of the survivors. Even the unfinished

55 M. Melchior, Zagłada i stosunki..., p. 68. 
accounts - by the ones who did not live to see the end of the war and left only fragments of notes - are still only kept as long as the authors are lucky enough to escape death. We do not know anything about the very bottom, about the last betrayal of which they were victims, about the way of sorrows of $90 \%$ of prewar Polish Jews" ${ }^{\prime \prime}$.

The time of production of a source is important. Documents written during the war or just after it ended, and the accounts presented in the first few years after the war have a natural taste of that reality being "freshly" captured. They are not plagued by errors of memory, imposition of knowledge acquired later onto personal memory. However, the phenomenon of "unlocking" agonizing, horrible memories often occurred only after many years have passed. Authors of the texts written for example in the 80s claimed that when they were writing in a sort of a trance they went back with their whole beings to the past events finding in their memory deposits of congealed content that was not touched upon in years. That was the case of Janina Bauman, who states the following in the introduction to her memoirs: "Almost forty years have passed before I felt ready to write this book. During those years I would rarely reminisce about the past. [...] I got deeply immersed in the past, forgetting about my current age and becoming a young girl again"57. It seems likely that majority of authors of late memoirs experienced similar feelings.

The value of the testimonies was decided not only by the time that passed from the described events, but also by other factors, closely connected with the time of the creation of the source. "In the archives, there are not many sources that are almost contemporary to the events, which are untainted by the complicated postwar context accompanying their creation" - Andrzej Żbikowski writes ${ }^{58}$. Of course, everything depends on the issue we want to isolate from the collected materials. Some threads are more marked by that political context, some less tainted, and some completely pure. Polish-Jewish relations in their broad sense are in particular prone to being distorted. For example, Aleksandra Bańkowska, in the introduction to her article Polish partisans 1942-1944 in Jewish accounts admits that she mostly used accounts from 1945 to $1950^{59}$. "It was the time of

56 J.T. Gross, Sąsiedzi..., p. 95.

57 J. Bauman, Zima o poranku [Winter in the Morning], Cracow 1989, p. 5.

58 A. Żbikowski, Teksty pogrzebane w niepamięci. Relacje dwóch uciekinierek $z$ masowego grobu Poniatowa [Texts Burried in Non-remembrance. Testimonies of Two Escapees from a Mass Grave in Poniatowa], "Zagłada Żydów” 2005, No. 1, p. 74.

59 A. Bańkowska, Partyzantka polska lat 1942-1944 w relacjach żydowskich [Polish Partisans 1942-1944 in Jewish Accounts], “Zagłada Żydów” 2005, No. 1. 
belligerent propaganda against Polish Underground State, Home Army, not to mention National Armed Forces, with simultaneous exaggeration of merits of Polish Workers' Party and People's Guard (Army) in fighting the Germans. Additionally, Jewish organizations were clear on their official position on Polish partisans, accusing them of being accessory to the Shoah" ${ }^{\prime \prime 0}$. Naturally, the distortions do not discredit the testimonies as such. However, we have to remember that personal documents are probably the most valuable source of knowledge on views, feelings, and mental state of individuals, their perception of reality and where they see themselves in that reality, rather than information on the real course of historic events; especially those in which an author of a testimony did not participate personally.

This issue is therefore connected with another one: the issue of credibility. It applies to the primary sources - personal documents. Insofar as from the historical point of view - as regards factual accuracy - personal documents "tend to have little source value" 61 , for a sociologist they are an invaluable source of information that are unobtainable in any other manner. We have to, however, carefully study the characteristic features of personal documents, so as not to be tempted to treat them as completely unbiased and equivalent sources. A trivial statement that one formulates thoughts different when writing and when talking (also depending on what one is writing, to whom talking and answering what kind of questions), forces a researcher to approach oral and written documents from different angles. According to Lawrence Langer ${ }^{62}$, oral accounts are at least partially free of the element of conscious creation of presented reality. When we write we can think about the content and form more, many important, "raw" properties of language disappear when one edits the style, refines the construction of the text, tries to novelize. There is always a peculiar auto-censorship in personal documents and the authors are often aware of that. In a specific degree, this concerns the memories written down from perspective of time. Introductions to memoirs can be therefore understood twofold - on the one hand, as an attempt to oppose a one-sided or incredulous perception of the text, and on the other hand, as a continuation of that self-aggrandizement, highlighting some motives or certain features of the text. Let me present just one example. Stefan Chaskielewicz, who wrote his memoirs when he was seventy, says the following in the introduction: "I was trying to recall the wartime experiences as precisely

60 Ibid., p. 150.

61 M. Melchior, Zagłada i stosunki..., p. 68.

62 L. Langer, Holocaust Testimonies: The Ruins of Memory, New Haven 1991. 
as possible and to write them down honestly. As time went by I think I judge my own actions more objectively and my attitude differently. But my memories are not full either. Each man conceals some events because of his own prudery and internal reluctance, which is sometimes hard to explain. I am no exception"63. Chaskielewicz has included conversations he had with other survivors in his book. He comments them in a similar manner: "Like in all memoirs, there must be some number of omissions here - as people are never completely honest when talking about themselves" ${ }^{\prime 6}$.

If we assume that each source classified as a personal document is burdened with various limitations, we should create their systemic presentation. Genre diversification of sources is natural, yet it forces us to be careful when using them simultaneously and interchangeably. Jacek Leociak ${ }^{65}$, among others, mentions this fact. Classification of literature of personal documents proposed by Leociak can be helpful in describing and characterizing the materials used:

A. Form of communication and recording method:
A.1. Written sources (texts),

A.2. Oral sources (audio cassettes, VHS and other);

B. Chronological division (date of creation of the source):

B.1. Texts created hic et nunc:

- journal and journal-chronicle,

- diary,

- letters,

- induced sources: accounts, answers in surveys etc.,

- borderland genres: essay-non-fiction prose, literary reportage etc.;

B.2. Texts created post factum:

- diary,

- autobiography,

- memoir,

- induced sources: accounts, court testimonies etc.,

- borderland genres: conversations, reconstructed journals etc.

63 S. Chaskielewicz, Ukrywałem sięw Warszawie [I Was Hiding in Warsaw], Cracow 1988, p. 7.

64 Ibid., p. 8.

65 J. Leociak, Literatura dokumentu osobistego jako źródło do badań nad zagładą Żydów. Rekonesans metodologiczny [Literature of Personal Document as a Source of Studies of the Shoah. Methodological Reconnaissance], "Zagłada Żydów” 2005, No. 1. 
We should also add a criterion of motivation for creating the source to the classification above, i.e. has the creation been induced by outside factors (institutions collecting accounts, diary-writing contest, interviews conducted by researchers etc.) or has it been created at the initiative of the author (letters, journals etc.).

I primarily use written sources. Majority of them are records of accounts form after the war, which were presented in Central Jewish Historical Commission (and in Jewish Historical Institute after 1947), and collected in the archives of Jewish Historical Institute in Warsaw, in unit $301^{66}$. Some of these accounts have been published i.a. in Life and Death of Polish Jews, 1939-1945. Testimonies of Witnesses eds. Michał Grynberg and Maria Kotowska ${ }^{67}$. Those accounts are a source which was institutionally induced, hence they are standardized to some extent (mainly the subject scope of the texts, their structure and character of the narrative). The great merit of those accounts is the fact that they were presented by many people who would never even decide to write on their own accord. Thanks to the works of the institutions we are able to hear their voice. From the whole collection of the accounts I have only chosen those whose authors have included an extended description of their experience of hiding, as there are many brief accounts, where the narrator sums up the fact of hiding with just one sentence and does not give any specific details. A significant percentage of the accounts has been written in Polish, but there are some texts which were translated from Yiddish. This limits our access to the original language and content - yet we are not condemned to be limited this way. From the available collection of accounts kept by Jewish Historical Institute and having over 7000 items, I have used 41 texts (two of them by Poles), and additionally tapped into the testimonies published in Grynberg and Kotowska's collection. Other texts were an important source of information for me as well: diaries and memoirs written during the war and after it ended. Some of them were published as books, some remain unpublished. Those include individual sources, created not at a request of an institution, but inspired by inner needs of the authors. Aside from published sources, issued by various publishing houses (including Jewish Historical Institute, Znak, Czytelnik, Ośrodek KARTA), I have used two journals deposited at Jewish Historical Institute in the collection with 302 reference number, as well as 8 testimonies from Grynberg and Kotowska's collection. Another important archive collection where I got text for analysis from is Yad Vashem in Jerusalem.

66 A. Skibińska, Źródła...

67 Życie i zagłada Żydów polskich 1939-1945. Relacje świadków [Life and the Shoah 1939-1945. Testimonies...], eds. M. Grynberg, M. Kotowska, Warsaw 2003. 
I have used seven extended texts from that collection; most of them are diaries written during the war and deposited in the archives after it ended (three of them have $\mathrm{O} 33$ reference number - that collection is entitled Collection of Various Testimonies, Diaries, Memoirs, and the other ones come from O3 - Testimonies Department Yad Vashem collection). Some of the texts which were originally deposited in an archive were published by Jewish Historical Institute - in "Bulletin of Jewish Historical Institute" and later in "Jewish History Quarterly".

Genre heterogeneity of the sources used is justified by them not being representative. Especially Chapter 1 would not have encapsulated a comparatively complete spectrum of cases, if it was not for using various types of sources. That chapter, however, does not have an analytical character, but a classifying one. It is to record incidence of various types of hiding places, therefore it seems that using heterogeneous sources is justified there. In the other chapters, I am also employing diaries, testimonies and journals, especially the ones created during the war (or shortly after it ended). They allow us to retrace the way the hiding people write about a hiding place and inside of it, what do they think about and how do they perceive the place in which they are. From there I have also drawn examples to some extent confirming the hypotheses I formulated to authorize me to use particular analytical tropes. I have built heavily on the sources that talk particularly extensively about the spatial aspects of hiding. Let us just mention e.g. works by Landsberg, Stella Fidelseid, Maria Koper, Menachem Katz, Leokadia Silverstein, Florian Majewski, and Chaim Icel Goldstein. Other texts supplied me only with short fragments describing the areas that interest me.

In the sources, I was looking for narrations on the space of the hiding places that would allow me to decode the records of existential experience of the hiding people, i.e. descriptions of sheds, cupboards, basements, barns, and dugouts. The motto for that search can be a thought borrowed from Witold Rybczyński. In his book, The Most Beautiful House in the World ${ }^{68}$ the author wonders if it is worthwhile to write about small, inconspicuous, anonymous buildings. Perhaps, they are not that significant, if we do not know communications about them from olden centuries... he explains this omission with a theory by Daniel J. Boorstin, who claims that historical sources are selective by their very nature. They only transfer to the future the things that are the biggest, best, richest, and best documented in their presence. Rybczyński states: "The similar thing happens with buildings. There is a lot of data about important historical monuments such as

68 W. Rybczyński, Najpiękniejszy dom na świecie [The Most Beautiful House in the World], Cracow 2003. 
the cathedral in Lincoln, and about the people who erected them. [...] however, we do not know much about simple wood-carvers and carpenters who were the true constructors of cathedrals. Their homes, or rather hovels, were built around the cathedral, were made out of shabby materials and either crumbled over time or underwent many changes and modifications throughout centuries. Mud huts are not durable, and the scientists have only gotten interested in such humble abodes in the recent years. Their illiterate constructors did not leave any documentation behind and the few buildings that survive today are after all mute. Who built a giant medieval stone barn in Great Coxwell in Berkshire, England? We do not even know when it was created. [...] Historians only confirm that it was built in the $13^{\text {th }}$ century. They do not know anything else" ${ }^{69}$. We know just as little about Jewish hiding places from the time of the occupation, the places that became a space for salvation of thousands of people who were oppressed and sentenced to die. Despite the abundance of the sources - diaries, memoirs and testimonies - what interests me most, the space of a Jewish hiding place, remains poorly detailed, or even evades description.

When reading the sources, we can see a particular pattern. Memoirs and accounts of the survivors concentrate on their activeness: fighting, escaping, handling difficult matters. Hiding oneself is understood as a passive, stable state, with nothing worth noting going on. "However, we still do not know how to talk about the hours dragging on behind a wardrobe, about waiting for water in a basement under a barn, about everything that is not a history, story, anecdote. So there is no narrative, no empathetic listener, reader"70. That is why the texts do not say much about the place of hiding itself. In an extensive text by Calek Perechodnik ${ }^{71}$ description of MS. Hela's room has only a little over one page. Sometimes, for example in testimonies collected in the Archives of Jewish Historical Institute, there is just one sentence or a few words on the place of hiding. This is not a subject that people like to talk about, and this is why looking for batches of texts that would allow us to recreate fragments of those spaces is that big of a challenge. Krzysztof Szwajca claims that active people, who survived largely thanks to their endeavors, are doing better with coping with their past experiences. Such people are also more eager to talk about their experiences connected with hiding, their narratives are dynamic, because they were doing something themselves - looking

69 Ibid., p. 14.

70 K. Szwajca, Kłopotliwa "świętość" [Troublesome "Sanctity"], "Midrasz" 2007, No. 1.

71 C. Perechodnik, Spowiedź [Confession], Warsaw 2004. 
for a hiding place, building it, making it better, etc. Their texts are structured by verbs creating a history of their activity (I primarily use those texts in Chapter 4).

It would be worthwhile to say a few words about the materials used more and more eagerly by the authors of works on the Shoah and which are absent in my book. I am talking about the sources classified as oral history. Synthetic approach to the subject of employing such sources was presented by Piotr Filipkowski ${ }^{72}$. He writes that currently we understand oral history as recording, archiving and later analyzing interviews conducted with actors in events that interest a researcher. Materials obtained in such a manner are perhaps less valuable for sensu stricto historians, but are invaluable in social sciences, as they provide us with data that could not be accessed in any other manner. Lately oral history is in the scope of interest of numerous researchers. There are detailed works being created that systematize the methodology of conducting and analyzing interviews, as well as their usefulness in studying the history of the Shoah ${ }^{73}$. The most important Polish works on Holocaust entirely based on sources obtained via methods of oral history are Holocaust and Memory by Barbara Engelking ${ }^{74}$ and The Holocaust and Identity by Małgorzata Melchior ${ }^{75}$. I do not suppose we need to convince anybody that we can collect precious and unique materials by conducting interviews with witnesses of history.

When I was beginning to collect the materials, I planned that - like in case of above-mentioned works by Barbara Engelking and Małgorzata Melchior the interviews will be the main corpus of the sources. I have been conducting such interviews for a few years with Polish Jews saved from the Shoah. In the beginning those interviews were conducted under Central Europe Center for Research and Documentation program (Vienna-Budapest) entitled Witness to a Jewish Century. The project assumed that the interviews shall be conducted with

72 P. Filipkowski, Historia mówiona a wojna [Oral History and War], in: Wojna. Doświadczenie i zapis. Nowe źródła, problemy, metody badawcze [War. Experience and Records. New Sources, Problems, Research Methods], eds. S. Buryła, P. Rodak, Cracow 2006; see also A. Skibińska, Źrodła...

73 A. Portelli, Death of Luigi Trastulli and Other Stories: Form and Meaning in Oral History, Albany 1991; M. Frisch, A Shared Authority: Essays on the Craft and Meaning of Oral and Public History, Albany 1990; The Oral History Reader, eds. R. Perks, A. Thompson, London-New York 1998; H. Greenspan, On Listening to Holocaust Survivors. Recounting and Life History, Westport 1998; P. Summerfield, Reconstructing Women's Wartime Lives: Discourse and Subjectivity in Oral Histories of the Second World War, Manchester 1998.

74 B. Engelking, Zagłada...

75 M. Melchior, Zagłada a tożsamość... 
Polish Jews born no later than in 1930 (therefore, it concerned wartime experience of older children and adults). Thus, I have conducted ten several-hourslong in-depth interviews under this project. I have later transcribed and studied them. I have concluded another four interviews under a project of Museum of the History of Polish Jews - Writing Down the Jewish World in Poland.

Sadly, even though the hours spent with my interlocutors proved to be highly informative and often emotionally moving, and though they provided me with substantial knowledge on the fate of Polish Jews, it turned out that my research concept cannot be carried out solely based on those conversations. The interviews were conducted by a detailed list of questions that touched upon memories of prewar life and were to help create as precise description of wartime experiences as possible. For my purposes, I have extended the list with questions on hiding both in ghettos and on "the Aryan side" (this was experienced by all of my speakers to a greater or lesser degree). I wanted to know where and with whom they were hiding, how did their hiding places look like, how did they spend their time in a hiding place, how did they deal with everyday activities, who aided them and how, what were their immediate threats... Thus, the questions were not tapping into afterthoughts, but facts and experiences. However, it turned out that while the speakers were eager to talk in detail about living in a ghetto, partisans, and living in USSR after being deported east, the subject of hiding places was virtually not suitable for discussion. People I talked with used various strategies of avoiding the subject, not always consciously. Those included "forgetting" ("I don't know, I don't remember"), trivializing ("There is nothing to say, nothing to talk about"), omission (they would swiftly and smoothly change the subject) or even refusal to answer (alternatively they would ask me to turn off the recording device). It turned out that the speakers marginalize their experience of hiding or try to treat it as vaguely as possible when constructing their stories. In some cases, they were probably really unable to present detailed descriptions of their hiding places due to gaps in their memory. However, I was under the impression that just like the issue of Polish-Jewish relations in its broad understanding or questions about personal experience of anti-Semitism, the subject of hiding is in some sort of a vague and dangerous zone that is better left not touched. Aside from pain and sorrow inevitably induced by recalling wartime suffering and loss of the lovedones, memory of the hiding places was perhaps awakening other negative feelings in my subjects. Fear, uncertainty, shame? I can only speculate.

It is possible that experiences of hiding, despite being common, are somehow special in the whole of biography of the speakers, but special in a negative way - amongst other, perhaps objectively more tragic events, yet about which 
they talked without hesitation and restraints we see here. Maybe the reasons for that are similar to the ones that make the researchers avoid the subject of the hiding places, as I have written above (it was diagnosed by Paulsson) as well as reasons making the authors of diaries and other testimonies write so little about the hideouts (it was diagnosed by Szwajca). Barbara Engelking has also asked "why didn't they want to answer?"76, yet she was describing a broader phenomenon: refusal to talk about wartime experiences in general. The author lists possible reasons for that: desire to escape those traumatic events, fear of hurtful lack of understanding or of dismissal and depreciation of their experiences, fear of their wartime actions and attitudes being judged, fear of stereotyping the fate they talk about and inability to forgive. Which of those reasons can apply to reluctance to talk about wartime hiding places? I cannot answer that question.

Confronting my scientific curiosity with a wall of silence or a mist of vague answers was a very enlightening experience. It turned out that we cannot find an answer to every research question by using seemingly optimal methods. It was also a lesson in humility regarding the fate of those affected by the Shoah - I have once again learned that a researcher, even if equipped with the best tools, prepared for the conversation and with vast theoretical knowledge, can be simply not welcomed into some corners of experiences of another human being. We have to respect that. As a result of this stage of my research, I have ultimately given up using oral history sources and chosen to use preexisting sources instead of induced ones. Authors of such sources wanted to talk (or write) about their hiding places.

\section{Methodology}

This book was based on a qualitative analysis of source material with attempts to interpret that material. In Chapters 2-4, building on various concepts deriving from social sciences and anthropology, I perform a detailed analysis of selected texts. Anthropological perspective allows me to tap into hidden areas of meanings, which could have stayed hidden in a different approach. Searching for those meanings seems paramount to me. Such research approach is for example exhibited by Małgorzata Melchior: "Through the prism of biographical experience of individual survivors we can see a certain social and historical reality or some aspects thereof (for example the situation of the Jews hiding on 'the Aryan side', Polish-Jewish relations during German occupation, scale of support provided,

76 B. Engelking, Zagłada i pamięć..., pp. 271-299. 
and - to some extent - phenomenon of denunciation and szmalcownictwo) and some general issues (for example the problem of identity and changes in identity, memory and commemoration, emergence and perpetuation of stereotypes and prejudices or - on contrary - altruistic attitudes). For that purpose, it is worthwhile to penetrate and recreate meanings given to the then reality by its actors, the meanings they attribute to their experiences and their own personal experience, testifying to them even many years after those events" 77 .

All the sources I use are autobiographical texts. Philippe Lejeune, who coined a well-known sociological concept of "autobiographical pact"78 wrote that an autobiography assumes an identity of the author, narrator and protagonist of the story - hence the reader assumes that he or she is reading about the life of a person undersigned as the author of the testimony. The texts I study - testimonies of wartime - are specific. War is the central and key aspect of an autobiography. We can actually say that in majority of texts (e.g. in testimonies) the wartime experiences are a sole subject of an autobiography. War is also the reason why majority of those texts were created. If their authors were not struck by tragedy of Nazi occupation, they would probably have no reason to ever pick up a pen. For obvious reasons the texts of accounts deposited in archives after the war would not have been created either.

When studying such exceptional texts, one should look for theoretical inspiration in modern qualitative sociology. In the last few decades there were many valuable works created in Poland and all over the world, which presented well thought-out research strategies, starting from now classical approach of Fritz Schütze's biographical sociology approach. In Polish sociological literature, there are comprehensive works on methodology of qualitative research ${ }^{79}$, which is why here I will only briefly invoke the most inspiring concepts.

Researchers distinguish many methods of working with texts classified as autobiographical materials. Paul Thompson presents a synthetic approach and describes four methods of analyzing such materials (Thompson writes about

77 M. Melchior, Zagłada i stosunki..., p. 67.

78 P. Lejeune, Pakt autobiograficzny [Autobiographical Pact], “Teksty” 1975, No. 5.

79 A. Rokuszewska-Pawełek, Chaos i przymus. Trajektorie wojenne Polaków - analiza biograficzna [Chaos and Compulsion. Wartime Trajectories of Poles - Biographical Analysis], Łódź 2002; M. Czyżewski, Analiza jakościowa [Qualitative Analysis], in: Encyklopedia socjologii [Encyclopedia of Sociology], ed. W. Kwaśniewicz, Warsaw 1998; K. Kaźmierska, Holocaust w narracjach biograficznych ofiar, sprawców zbrodni oraz ich rodzin [Holocaust in Biographical Narratives of Victims, Perpetrators and their Families], "Kultura i Społeczeństwo" 1999, No. 1, and others. 
recorded interviews, but his typology can be also applied to analyzing other personal documents). Those include:

1) presentation of individual autobiographical story and analysis thereof in a broader historical and social context;

2) presentation of a collection of stories and grouping them around specific subjects;

3) narrative analysis of individual interview or a group of interviews, focused on language and particularities of a given document;

4) reconstructing cross analyzing, where, based on many accounts, we draw conclusions about the events, processes, patterns of behavior from the past ${ }^{80}$.

To meet my research assumptions - i.e. to delve into a particular phenomenon, which was present nearly everywhere on the territory of occupied Poland and which was pertained by many people, I have decided to choose an approach closest to the one described in item four. I did not want to choose just one or a few stories from such a plethora of materials and forego analyzing the rest. I still had to be selective about the texts I have ultimately decided to use (remind you, the collection of testimonies deposited in Jewish Historical Institute alone has more than 7 thousand items!). Another argument for choosing the method of analyzing many testimonies was their character. As I have already mentioned, in some texts the descriptions in which I am interested take up only a small fragment of the whole. There are extremely few testimonies to a greater extent devoted to the subject of hiding and with extended descriptions of the space of hiding places. Therefore, to get as close as possible to understanding the phenomenon of hiding places, I had to draw on numerous texts, looking for similarities, common threads, converging points of view, recurring motifs.

I was convinced about making the right choice by other theoretical approaches, for example the views of Daniel Bertaux, who advocates studying a saturated collection of autobiographies ${ }^{81}$. An example of such collection is a selection of few dozen testimonies and journals from archives of Jewish Historical Institute and Yad Vashem. Studying a number of texts describing individual, unique, and yet in a way similar experiences does not secure statistical representativeness, but gives a hope of phenomenological representativeness, and, in consequence, an empathetic and exhausting interpretation of the collected material. I have

80 P. Thompson, The Voice of the Past, Oxford 2000, pp. 269-271.

81 D. Bertaux, Funkcje wypowiedzi autobiograficznych [Functions of Autobiographical Statements], in: Metoda biograficzna w socjologii [Biographical Method in Sociology], eds. J. Włodarek, M. Ziółkowski, Warsaw-Poznań 1990. 
decided to adapt Bertaux's perspective only partially, as it assumes something that I believe to be inappropriate when studying personal documents on the experience of the Holocaust. Bertaux believes it to be important to objectify the analyzed texts, treats them as a documentary source of knowledge about reality, while disregarding subjective meanings attributed by individuals to their lives. I was only able to assume that perspective in Chapter 1, where, based on the texts I know (and studies by other authors), I have created a typology of hiding places according to objective criteria.

Theoreticians of qualitative research are keen on invoking the classic: The Children of Sanchez by Oscar Lewis ${ }^{82}$. This book is invoked by Norman Denzin and Daniel Bertaux as well. Denzin classifies Lewis's book to be a part of interpretive format school, calling this way of conducting research "from the subject point of view". It seems to me that it is impossible to assume a different perspective when researching the history of the Shoah. In this approach - and in the whole of qualitative research, in Poland lead by Florian Znaniecki - it is paramount to let the authors of the testimonies speak with their own voice. Znaniecki represents humanistic sociology and is an author of a postulate aimed at researchers of social phenomena: for them to take into account when analyzing that phenomena that they are a current or a potential object of operation of tangible, living, thinking and feeling people. This way Znaniecki has introduced a notion of humanistic coefficient into scientific circuits. It is a specific feature of every person and social construct: sense and meaning attributed to them in human understanding and experience. According to the then innovative methodological approach of Znaniecki, sociology has to turn to a subjective approach, so as to see the world through the eyes of the actors of the researched actions. It was Znaniecki who was a precursor of studying social phenomena through analyzing personal documents. The concept of humanistic coefficient is in general similar to the theory of understanding (Verstehen) by Max Weber and empathy (Einfühlung) by Wilhelm Dilthey. I am more akin to agree with Dilthey's views. He distinguished between natural and a social science, arguing that life scientist strives to discover the nature, while a humanist - to empathize with phenomena or understand them.

Looking at the world of hiding places through the eyes of the authors of the testimonies is the only way to touch the reality we wish to describe. We have to let them guide us into that world. We explore that reality through their autobiography, hence we see it as they did. We analyze meanings they have ascribed

82 O. Lewis, Sanchez i jego dzieci. Autobiografia rodziny meksykańskiej [The Children of Sanchez: Autobiography of a Mexican Family], Warsaw 1964. 
thereto $^{83}$. We can supplement this research strategy with other interpreting approaches described by Denzin. One of them is a sociological, psychological, and anthropological interpretation of autobiographies created by the subject without interference of the researcher (subject-produced autobiographies). I certainly use this approach, since I analyze texts that were created many years before I was born. Another element or interpreting approach according to Denzin is making sense of an individual's life.

Another methodological advice useful when analyzing texts from the times of the Shoah could be using the concept of rounded theory, authored by Anselm Strauss and Barney Glaser ${ }^{84}$. They emphasize the point of view of the actors involved in a social reality, admitting that those actors understand the phenomena they are engaged in best. Consequently, a researcher should not analyze social phenomena based on previously prepared hypotheses. The right way to understanding goes in the opposite direction: starting with collecting the research materials (e.g. texts of personal documents to be analyzed), a researcher does not assume what will be found in them. The researcher allows a theory on a particular social phenomenon to emerge from the collected and analyzed material ${ }^{85}$.

On the margin of those methodological notes I would like to point out that an approach of ethnologist- anthropologist can be very useful, as such a scientist observes a particular society and describes it without a presumption of collecting standardized and fully representative data. Such a scientist believes signs, symbols, human behavior, and senses we can find in them to be important. The things that are unclear and vague are at the same time essential: myth, belief, word, gesture, archetype preserved in speaking and acting.

I find Erving Goffman's approach to be kindred to mine. Jerzy Szacki, in the introduction to the Polish edition of The Presentation of Self in Everyday Life, described the study by Goffman to be "closer [...] to ethnographical monograph than to a standard sociological monograph. Goffman looks upon the simplest human actions under natural conditions, records them and tries to unveil their hidden sense cloaked for a superficial observer. [...] For him each human activity

83 N. Denzin, Interpretive Biography, London 1989; Interpretive Interactionism, London 1989.

84 B.G. Glaser, A.L. Strauss, The Discovery of Grounded Theory: Strategies for Qualitative Research, Chicago 1967.

85 K. Konecki, Studia z metodologii badań jakościowych. Teoria ugruntowana [Studies on Methodology of Qualitative Research. Grounded Theory], Warsaw 2000. 
seems filled with meaning" ${ }^{86}$. Goffman does not ascribe the power of proof to the examples he quotes, he uses them for the function of clarifying depictions. He does so knowing that his claims will not form universal theories that would later create a system clarifying patterns of functioning of society. He rather strives to present that some things occur "sometimes", "usually". Those examples allow us to look at the reality in a certain way, to describe it with certain language and, perhaps, make a part of it clearer. Goffman refuted accusations of non-representativeness of the sources or not choosing the sample carefully, saying: "Although many of these data are doubtful worth, and my interpretations - especially some of them - may certainly be questionable, but I assume that a loose speculative approach to a fundamental area of conduct is better than a rigorous blindness to it" ${ }^{\prime \prime}$.

Perhaps, we should bear Goffman's words in mind when studying such a sensitive and complicated matter as the experience of the Shah. When it is hard to compile a collection of homogeneous sources, it would be a waste to forego fascinating and important texts that we would have to discard e.g. because of the time they were created or their genre. Being conscious of methodological limitations we have to be open to all the voices reaching us from there. From the point of view of a researcher of the Shoah the most valuable thing is to carefully listen to those voices, make attempts, articulate intuitions, ask questions and make hypotheses, and to abandon all-clarifying answers.

86 J. Szacki, Przedmowa [Foreword], in: E. Goffman, Człowiek w teatrze życia codziennego [Presentation of Self in Everyday Life], Warsaw 1981, p. 17.

87 Ibid., p. 20. 


\section{An attempted typology of the hiding places}

All Jews who were hiding could tell their story of vagrancy and homelessness by describing the places where they were waiting for an improvement of their situation, the end of the war, the salvation. Each of those stories could be completely different, just as different and incomparable as the destinies of individuals are. Their hideouts are a whole spectrum of places clawed away from space. They were often absolutely unbelievable (e.g. a toilet in a yard of a town house described by Ignacy Bierzyński-Burnett or a well in which families of Koppel Holzmann and Wilhelm Dichter were hiding) and often quite ordinary, like a basement, a room behind a cabinet, a shed or a barn. However, to identify the phenomenon of a Jewish hiding place during the Second World War, we need to create at least a partial systematic categorization, as we are unable to examine and analyze each story individually.

Being aware of how difficult it is to create such taxonomy and of how openended and imprecise the proposed categories might turn out to be, I have still decided to create a typology of hiding places. I have abandoned a commonly used category: "ghetto - Aryan side". This division is used when analyzing all aspects of the experiences of Polish Jews during the Shoah. However, I believe that when depicting hiding places understood as places of hiding, dwelling, this category is not important from epistemic point of view. The following analysis will indicate that nearly all kinds of hiding places could have been equally common both on the "Aryan side" and within the ghettos. It also seems that this historical and political category falls within a different order than the categories I propose. The latter are strictly practical and apply to time, space and involvement of groups and individuals. While depicting given categories and listing specific examples, I indicate where the hiding place in question was located, as this often influences which category this case falls into, yet I do not incorporate "ghetto - Aryan side" category to my system. I spend more time deliberating some types of hiding places and approach other types quite briefly. It is not a resultant of a statistic frequency of one hiding place or another. To some extent it was influenced by number of available texts where descriptions of given hideouts were presented. Some types are simply more present in the discourse on the Shoah, as e.g. hiding places in the Warsaw Ghetto or in ghettos in other big cities. Other - such as hiding places in the countryside or on "no-man's-land" - are yet to be saved from the oblivion or ignorance. 
War-time hiding places of Jews can be systemized according to various criteria. I propose the following categories of division:

- Depending on planed and/or real time spent in a given place: temporary and long-term;

- Depending on presence or lack of outside help: independent and assisted;

- Depending on a location: in the city (small and big cities), in the country or in a forest;

- Depending on number of people hiding therein: solitary and collective.

I have also introduced a separate category "wandering - looking for a hiding place". I believe it is essential to compliment the picture emerging on the basis of characteristics of particular categories of hideouts. For one should realize how fragile and unstable was the reality of the people in hiding, even in long-term hideouts. At any time, a hiding place could have lost its virtues - it could have been uncovered, destroyed, lose its status due to a decision of its host or an owner of a given place. Numerous "moves", difficult times of living outside a hiding places and looking for an adequate space are an important, "dynamic" phase of the process of hiding - as important as the "static" periods of staying in relatively secure hiding places.

The categories I have listed to describe hiding places are not disjoint; in numerous cases, they intersect and overlap. Therefore, one and the same hiding place could have undergone transformation. The above approach is not to serve a rigid categorization, but is only to organize a set of characteristics helpful while describing a phenomenon of a hiding place. When familiar with such a typology we gain a tool allowing us to look into testimonies of the people in hiding from a different angle. While citing those testimonies I was trying to choose examples illustrating each category. It was not my ambition to classify all testimonies I know to a given category. I was rather hoping to map the scope of the study and to present the described phenomenon in all its diversity before attempting a sociological and anthropological analysis of a space of a hiding place.

\section{Temporary and long-term hiding places}

This category was created based on the criterion of planned time to be spent in a hiding place. First, we need to look closely at this criterion. By its own definition and due to external circumstances a hiding place could never be treated differently than as a temporary place of residence. "Temporary" means, for example, until the end of the war, i.e. a moment when hiding will no longer be a necessity. Nobody assumed they would spend their whole lives in hiding. 
However, the scope of this temporary nature is important. I have assumed that for the purposes of typology the following distinction will prove practical: a hiding place can be deemed temporary if it was used to hide in until an imminent threat passed and if it was chosen in the heat of the moment. They were not searched for in particular - they can be also referred to as improvised or coincidental, as it was often a coincidence that led people to given hideouts. Those hiding places were most often found intuitively. Word "momentary" can be used as a synonym of "temporary". Time spent in a temporary hiding place, waiting for it to be safe to come out could, of course, extend to over 24 hours, but my definition assumes that nobody planned an overnight stay in such a hideout. The stay is such hiding places lasted for hours rather than days.

In contrast, long-term hiding places, as I describe them, are places where people planned to stay for longer and spend a night. Time spent there could extend to months and even years. A plan of staying in a long-term hiding place was normally connected with setting rules, gathering supplies and adapting the premises.

\section{Temporary hiding places}

Examples of temporary hiding places primarily include the ones used during displacement actions in ghettos. A highest sample of them can be found in accounts and memories from the Warsaw Ghetto; those include descriptions of improvised hiding places during Gross-Action Warsaw.

The mass extermination of Jews from the Warsaw Ghetto started on $22^{\text {nd }}$ July 1942. The architecture of Warsaw tenements made this task easy for the Germans: it was simple to cover the exits from the house, check the floors and drag out resisting people from the apartments. Instinct pushed people to hide even if their hiding places of choice would not prove durable. Often nothing was changed in the rooms, people tried to make the most of that scrap of space where they found shelter against the blockade. At the sound of footsteps on the stairs a person who wished to escape death had no time to devise a strategy. First glance at a well-known space hinted at a way to save oneself. It was easy for the Germans to guess where people would hide from being forced away. However, sometimes a house would turn out to be a mysterious labyrinth and the space twisted, turned, shrank and led to previously unknown nooks and crannies: places in which nobody would be able to hide in different circumstances. Thus, the fundamental characteristic of nearly all of improvised hideouts is the "impossibility", which is supported by numerous examples. 
Such an incredible story is told e.g. by Ita Dimant, who was a twenty-something-year-old girl during the war: "Saturday, August $1^{\text {st }}[\ldots]$ Loads of policemen in the yard. Whistles and cries: 'out!'. Everybody down. You could already hear shots. I dash up the stairs to cover, to hide somewhere. [...] There is an attic, but there is no place to hide. Some hole in the wall. I go through that hole. A parcel slips out of my hands. I'm now at an identical attic. God, I don't have my leather bag with documents and money. Now I'm done. I jump through that same hole again. I look for the bag - it's not there. But wait, this is not where I was before, this is a different attic. Another hole in the wall, I go through and there's an identical attic again. Have I gone mad? I look around with wild eyes, I keep jumping through some hole and it would seem that I am still at the same attic. I get to some staircase thinking that it might lead to some other yard - I hear police whistles downstairs, their feet stomping on the stairs and them banging on closed doors. So I dash back, I jump through the hole in the wall again and I don't know what's going on with me anymore... I crouch in some corner, bite on my fingers till they bleed and franticly think: no, no, just don't go mad, don't lose consciousness, maybe they won't come here... suddenly, while hectically looking for a place to hide, I uncover large iron door. I drag them to the corner of the attic, put them against a beam sticking out about fifteen $\mathrm{cm}$ from the floor - and I stretch on the floor covering myself with that door. I also cover my head with some rags and trash and I'm lying there. [...] Somebody enters the attic... one came, another he is above me... [...] they haven't found me - they moved on. For someone to be under iron cast door placed almost on the floor - they couldn't suspect it" ${ }^{88}$.

No analysis could guarantee suitability of a hideout; as it was in Its case, it could all break down to a twist of fate, a coincident: will they look here or not? Sometimes they were in a hurry. Sometimes they had dogs. Sometimes a hiding person was able to wait a minute longer and survive. In July 1942, the following happened to Edward Reicher: "One day when I was at the office I suddenly heard: 'All Jews out!', the German thugs bellowed. I felt hot. When did they get here? I heard their heavy steps on the stairs. Where to hide? In the doctor's office. There was a tool cabinet in the corner. Sadly, it had high legs. I hid behind it. My legs were visible. I was scared. My colleague, doctor Goldlust, was shot in his apartment, where he was hiding. I was trying not to breathe. 'Open up!', they yelled outside the door. I did not move. They broke down the door with a rifle butt. Soldiers entered the hall. 'So, that's it', I thought. They got close to the cabinet. They were taking out tools and instruments, looking at them and cracking jokes. Within moments they

88 I. Dimant, Moja czastka życia [My Piece of Life], Warsaw 2001, pp. 58-59. 
left. I lied down on a settee and breathed deeply. I was shaking all over but they did not notice my legs. Generally speaking, cabinets played an important role in the rest of my life. With a bit of luck, they could save a life"s9.

In other ghettos, the pattern of mass displacement was generally similar, as were the salvation attempts. Sewers and gutters often became a temporary hiding place: Abraham Chomet ${ }^{90}$ writes about this way of hiding oneself during such an action in the Tarnów Ghetto, and in the Łódź Ghetto, during "szpera" ["rootle" translator's note] in October 1942, Sara Zyskind lied down in a gutter to wait out the manhunt ${ }^{91}$. In one of her short stories from Ebbing Garden Ida Fink narrated the following story: "When the cars arrived at the square in front of the bathhouse, I crouched in a corner between two houses and covered behind a broom. No one, neither SS nor Ordungsdienst haven't thought that somebody was there because of the broom. I was trembling so much that the broom was shaking. I heard everything, as first they locked them up in the bathhouse before they loaded them in the cars. [...] You know... somebody was running and tipped the broom. It fell over and if somebody was to look in the corner, it would be the end of me. I was afraid to put it back up, as they were now leading them to the cars"92.

Ida Fink describes another "impossible" improvised hiding place, paradoxically effective because it had no door: "We - seven people - hid in a building that used to be a pigsty, which, aside from other properties of a shelter, was lacking a door. There must have used to be some sturdy one there, as was indicated by an arched vault over the opening and by hooks and nails sticking out of it. Shelter with no door is clearly madness. However, among other things, we were saved then precisely because there was no door. When faced with a locked door, the Germans sweeping the yard and farm buildings would surely push them and therefore sentence to death seven people, who were sitting there in leftover hay from when there used to be pigs. However, since they saw a black gaping hole from kicked out door which was barely covered by a pile of dry, leafless branches, they skipped it with a clear conscious, not suspecting the existence of people hidden inside" ${ }^{\prime 93}$.

89 E. Reicher, W ostrym świetle dnia. Dziennik żydowskiego lekarza 1939-1945 [Country of Ash. A Jewish Doctor in Poland 1939-1945], London 1989, p. 47.

90 A. Chomet, Zagłada Żydów w Tarnowie [Holocaust in Tarnów], in: Zagłada tarnowskich Żydów [Holocaust of Tarnów Jews], eds. A. Pietrzykowa, P. Potępa, Tarnów 1990.

91 P. Zyskind, Skradzione lata [Stolen Years], Warsaw 1991.

92 I. Fink, Odpływający ogród [Ebbing Garden], Warsaw 2003, pp. 67-68.

93 Ibid., p. 101. 
Massively relying on temporary hiding places during displacements became somewhat of a genesis of subsequent construction of bunkers on the territory of the Warsaw Ghetto. In 1942 people found out that the simplest, the most obvious hideouts such as a closed room with a wardrobe covering its door were not enough. Sometimes this line of thought emerged even during Gross-Action: a story of Artur Ney can be an example of that. After spending a few hours in an improvised hideout at Umschlagplatz, he has decided to look for a more secure location: "At one point, me, mommy and two other convicts found ourselves in front of a guardrail separating us from a square leading up to the boxcars. I don't remember what I was thinking about at that point, when suddenly 'alles zurück', we were all sent to Umschlagplatz. So we were the first ones sent to the square to wait for the boxcars. Our first thought was to hide, to communicate with father and to try to find my sister, as well as try to break free from that prison. Mommy wanted to hide in a dumpster standing in a yard. I wouldn't agree, because Germans could have killed us there, as they kept throwing things in there. We hid in a room with corpses, furnaces and various clutter. We got into a closet in a big wall clock, covered ourselves with corpses and spent three hours in that position. Good thing we hid, because right after we did they rushed the rest of the people to the boxcars. There were not many people who did what we have. All those people, once they got to Umschlag, have given up and were not trying to hide or run. Another thing is that not everybody had a place to run to and means to do so. [...] So, after three hours of crouching, I have decided to do recon, exchange bread for water, stretch my legs and look for my sister. Mommy stayed in the locker. [...] After meeting up with mommy, we have started thinking about what we should do next, where we should spend the night and how would we escape from there. They didn't let us stay overnight in the hospital, so, without them knowing, we hid in the attic, where a few families were there already. We spent the whole night in that attic"94.

Numerous testimonies show that special hiding places were prepared for the time of an anticipated action - they were supposed to be temporary, just to lay low for a few hours. However, we cannot call them "improvised". Such hiding places were prepared in all of the ghettos, not only in Warsaw. Zofia Dulman described a hideout during an action in the Kovel Ghetto: "At Eda's place we, about 30 people, run into a small, cramped room. There was a window out to the hallway, boarded up from the outside and covered with a wardrobe on the side of that hallway, and the door, or rather just a door frame, [through] which we

94 A. Ney, Pamiętnik [Journal], "Biuletyn ŻIH” [Bulletin of Jewish Historical Institute] 1999, No. 189. 
entered, was also covered, but from the room's side, with another wardrobe. We sat there for 24 hours in one position; the room was stuffy, crowded, dark, we had no food (we didn't feel like eating anyway)" 95 .

People used temporary hiding places not only during ghetto actions. Very often such a hideout was a pit stop for escapees from a ghetto or a camp, looking for a permanent shelter or waiting to get Aryan papers. Therefore, it followed a pattern of wandering. Ignacy Bierzyński-Burnett, after escaping a camp in Bliżyn, came to Warsaw on $16^{\text {th }}$ December 1943 with a friend. Their acquaintance lived at 46 Solec Street and they were planning to contact him. This is what those two young men did: "When we got to the yard we saw a building in front of us, and on the other side of the yard a giant dumpster and a sign behind it indicating a restroom. It was a typical, big Warsaw tenement. We entered the restroom without a second thought. There was a urinal on the left, which was painted black a long time ago. There was a niche above the urinal, about 2 meters above the ground, with the only window in the restroom. Staszek spent his first night in Warsaw curled up in that niche. He would later use this place a few more times. [...] There were 4 stalls in the restroom, separated from each other with about 2-meter-high brick walls, each with cement floor. We locked ourselves in one of them. We had to devise our action strategy while sitting there. It was still too early to enter an unfamiliar flat in occupied Warsaw and start asking around about a friend. We have decided to keep switching stalls every few minutes, so as not to arouse suspicion about why one of them is constantly occupied. We kept quiet when there was somebody else in the restroom using the stalls or the urinal. [...] Time was passing. We must have switched stalls about 50 times without arising suspicion. Various people came and went. The evening came and it got dark. There was, of course, no light in the restroom"96.

Henryk Schönker mentions an even more uncertain and unstable hideout. When a carpenter's mother cast them out of a bunker near Wieliczka, the Schönker family began marching into the unknown, "as far away from this house as possible, the house that was supposed to be our shelter and now turned out to be our biggest threat"97. They found two female dead bodies in a meadow. They have decided to hide: "We couldn't stand there for too long, as there we were visible from afar. We went over to the bushes and father went to see if there's

95 Z. Dulman, Relacja [Testimony], in: Życie i zagłada... [Life and Holocaust...], p. 578.

96 I. Bierzyński-Burnett, Po śladach pamięci. Walka o przetrwanie czasu Wielkiej Zagłady [Tracking the Memory. Struggle to Survive the Great Shoah], Warsaw 1995, pp. 34-36.

97 H. Schönker, Dotknięcie anioła [The Touch of an Angel], Warsaw 2005, p. 123. 
anywhere to hide there. The bushes turned out not to be very thick and anyone who would came near would see us. We had no choice, though, and father decided we were to wait there until the evening came"98.

That day Henryk Schönker went to the town to get bread and used improvised hiding places twice more. First in actor Gottowt's apartment: "I was standing there with a sausage in my hand and just like that I jumped under the bed just as Gottowt lied down in it. I have only managed to hide my legs when a few Germans entered the room. I didn't see their legs, I was facing the other side. I was lying there lifelessly, but I heard them talking"99. When he left the killed actor's apartment, he had to hide once more along the way, this time in a shed filled with hey.

Among temporary hiding places - although not necessarily spontaneously improvised - we have to list a special category of "a hideout within a hideout". This phenomenon was most often functioning in case of people hiding "on the Aryan side". When there was danger, e.g. unexpected guests, there was a need to hide even deeper. Experience of Sabina Rachel Kałowska could serve as an example here. After escaping a ghetto in Jędrzejów, she found shelter at her friend's Tola place. In her memoirs, she mentions two examples of "a hideout within a hideout": first, when Tola's friend was visiting, she had to stay in a closet. Another example is another time when guests were visiting. This time Rachel was hiding in a bed: "Rafał and Heniek covered me with some linen and put it along the bed against the wall, as people would, covering it with some bedspread [...] and those guests would sit at the edge of that bed"100.

Marian Berland and his family's situation was similar. They were hiding in an apartment at 40 Sienna Street in Warsaw, at Zdziś and Halina Krzyczkowski's place. The hosts gave the hiding people one room, but that was not always enough. "Both Zdzisio and we agree that we need a cubbyhole. Even if we never use it. Without it none of us will ever be at peace. [...] We have to completely brick up the entrance to the apartment from the devastated stairwell's side. Next, we have to make the second room smaller, divide it all the way from the window to the back wall. We have to build a giant wall across the whole room, so that there will be a narrow room between the bricked-up door and the newly erected wall. It will be one meter wide at best. This way we will get something like a third room, one meter wide, but six meters long"101.

98 Ibid., p. 123.

99 Ibid., p. 130.

100 P.R. Kałowska, Uciekać, aby żyć [Run to Live], Lublin 2000, p. 87.

101 M. Berland, Dni długie jak wieki [Days Like Centuries], Warsaw 1992, p. 309. 
Another specific form of a hiding place was a "half" hideout, where e.g. one would spend only days to go back to one's own apartment at night. It is hard to classify this hiding place according to temporal category, but it has more tangents with a temporary hiding place - a real home, which is abandoned for a part of a day, stays in its place and is a reference point, people could take food and necessary items from their home. It was a relatively common model on the territory of ghettos, since even though there was an imminent threat during actions and blockades, people still kept some freedom of movement. A story of a girl from the Łódź Ghetto is an example of that: "We took a pot of soup and a quarter of loaf of bread and snuck out of the house. [...] All the stairs were broken down in the abandoned house. Dad made a makeshift ladder from a chair and a few boards. We used it to climb up to the attic and pulled the ladder up on every floor. Half the way up the soup spilled. After getting to the attic we sat down huddled together. The wind was whistling and howling around us. [...] The first day in hiding just wouldn't end. We ate the bread and the rest of the soup, but the hunger was still twisting our insides. At the dusk, we snuck back home. Next day in the morning we came back to the hiding place with another quarter of loaf of bread and a pot of soup from the other half of rutabaga and leftover flour. Dad brought a hammer and nails and made a proper ladder. It was the fifth day of szpera and we kept on hiding, hungry, terrified and trembling from the cold. On the sixth day, there was no more soup. We cut another quarter from half a loaf of bread and left the last piece home. If we had taken it, we would have eaten it and have nothing left. The hours were dragging on. Now we were able to clearly hear hoof beats, Germans talking, screams and rattling sound of rifle shots. [...] The next day we took the quarter loaf of bread with us. Father took the prayer shawl, phylacteries and The Book of Psalms"102.

It seems that temporary hiding places were a fairly popular phenomenon. It can be concluded that they were most common in ghettos, where people would protect themselves from displacements. Those were places which were found instinctively, upon great fear, nervousness, in state of heightened attention. Those places were often unbelievable, uncomfortable, not suited to shield a living person. Sometimes a place that was not even hidden from the eyes of others functioned as a temporary hiding place - the only one possible at a given moment. After leaving a ghetto, while looking for a permanent place to stay, the temporary hiding places also functioned as a pit stop along the way to a target destination.

102 P. Zyskind, Skradzione... [Stolen...], p. 86. 


\section{Long-term hiding places}

Nevertheless, long-term hiding places were a basic and common phenomenon. They were supposed to provide shelter for an unspecified period of time, but, in contrast to temporary hiding places, the time spent inside of them lasted for months rather than days or hours. Those hiding spots, vis-à-vis the previously presented ones, had to comply with a number of conditions. First of all, they had to be more spacious, so that one could spend more than just a few tense hours there. The tension made it possible to withstand an uncomfortable position. Securing food and water was essential - either by stockpiling on the premises, steady supplementation connected with going outside or with a help from somebody from the outside. The same went for physiological needs: an issue of taking out buckets of excrements had to be dealt with or an alternative had to be worked out. Those are just some matters one had to consider when planning to hide somewhere for a longer time. They were easier to handle when hiding in somebody's home or at a farmyard; bunker and dugout constructors or residents of ruins had to exhibit imagination specific to architects and engineers to plan everything successfully (I write more on the subject in Chapter 4).

Long-term hiding places were prepared under various circumstances. Sooner or later some Jews escaped ghettos to "the Aryan side" and were looking for a permanent place of residence. People who run away from trains taking them to camps or from camps themselves were looking for shelter as well. In some towns ghettos were never created and people were comparatively free there before the displacements started. When it became apparent that a given town was to come to be Judenrein, hiding places were prepared for people to survive the period of the Final Solution, but also to hide when, according to the Germans, no Jew was allowed to be around.

It often happened that a stay in a hiding place planned as a temporary would prolong and in time a hideout would change its status. In autumn of 1944, after Warsaw uprising, Chaim Icel Goldstein's group went down to a basement without sufficient food and water provisions: "during the first five days, we thought we would not stay there long"103. Over time it turned out that there was no other way - the hiding place became long-term and they had to go out to find food and a spring or a well. A resident of Lubaczów, Eugeniusz Szajowski, recalled a similar situation. His family was sheltering a Jewish neighbor for almost one and a half year: "At the end of 1942 and in the beginning of 1943, when there were rumors of liquidation of the ghetto, Szulim Szwarc arranged to be hidden by

103 C.I. Goldstein, Bunkier [Bunker], Warsaw 2006, p. 21. 
somebody who lived at Kościuszki Street (in the barracks district). Meanwhile, for reasons beyond his control, the situation took a different turn. He was unable to use the promised hiding place. Being in a critical situation, he begged Rozalia and Marian Kościelski for shelter and rescue. [...] Not without fear (as they were risking their own and their children's life), but with Samaritan, catholic conviction that they had to help, the Kościelskis agreed and began to prepare a shelter. In the beginning, they used a small basement, later a shed in their backyard. Chopped wood was arranged in there to create a fake wall. Szulim Szwarc's hideout was located behind this wall. He was supposed to stay there just for a few days. That was not the case. Liquidation of the ghetto was swift and ended in two days. There was nothing to which one could go back and resurfacing hastily could result in death. And so that hiding place went from being temporary to sheltering Szulim for 16 months, i.e. from $8^{\text {th }}$ January 1943 to $27^{\text {th }}$ April $1944^{\text {"104 }}$.

However, temporary hiding places were usually not prepared well enough to allow for a longer stay. As I have previously mentioned, their ineffectiveness during displacement actions encouraged many people to prepare more dependable hideouts in case of any future actions. Some started building shelters as soon as they heard about the danger. I shall use another example from the Warsaw Ghetto. Anna Meroz described a situation in the summer of 1942, during Gross-Action as follows: "During that time people were constructing hiding spots wherever they could to hide during roundups. By chance I have once heard my neighbors talking about a hiding spot in our apartment building. There was a double roof in the attic and one could hide there during a raid. When we were going to work one day, somebody warned us not to go downstairs, as there were Germans outside. I felt all my blood rushing down to my legs, stood there stunned for a while and later said to my husband: 'Come, there is a hideout on the roof, they have to let us in, because we know'. There was an unwritten low saying that whoever knew about a hiding place had a right to use it, because if somebody was not let in and would get captured by the Gestapo, that distraught person could expose the ones that wouldn't let them in"105.

Marian Berland shared the sentiments of the builders of that hiding place. He later wrote in his journal: "During that war it turned out that a man who is unseen and unheard can feel the most secure about his life. With this truth in

104 http://www.zydzi.lubaczow.pl/index.php?kat=wspomnienia\&id=1

105 A. Meroz, $W$ murach i poza murami getta. Zapiski lekarki warszawskiej $z$ lat 19391945 [In and Out of the Ghetto Walls. Notes of Doctor from Warsaw 1939-1945], Warsaw 1988, p. 27. 
mind, after moving to Muranowska, we have started thinking about setting up hiding places for our families"106. However, those hastily prepared shelters were in fact often treated as temporary. Henryk Hoffman from Drohobych wrote: "We moved into a small flat at Garbarska Street and when people started talking about an upcoming big action targeting unemployed people and the elderly, we have decided to turn one of the cellars into a hideout. Every day after I came back from work, I, the son of the owner of the house and father would wall in one of the niches in the basement with bricks and old boards. We would create something like a wall with shelves, on which we would put jars of pickles and empty stone pots, as one would in a typical basement. This way we were covering fresh plaster and an entrance, through which we had to crawl. Inside the shelter we put two wooden benches, two chairs and a bucket. We could hide there for a short time only"107.

Bunkers and other shelters were commonly built, not only in Warsaw, but - as we can assume from what is written in memoirs of people from distant towns almost in every ghetto in Poland. It often happened that people spent a few or even a dozen or so months in hiding, despite extremely difficult conditions. Therefore, I put all the hiding places "at the Aryan side", in which people planned to hide until the end of the war, in the long-term category. Those include hideouts at somebody's home, in a pen on a farm, and dugouts constructed individually in the woods. On "the Aryan side" people would also build bunkers, there was a big number of them in Warsaw alone ${ }^{108}$. What could they look line? A construction under Koźmiński family house in Wawer is described by Halina Frydman like so: "I remember when that bunker of ours was being built. Buckets of dirt were taken out by human chain at nights. We built a cellar supported with pit props. Next to a tile furnace heater there was a copper cover. Underneath that cover there was an entrance to the bunker, accessible by a ladder. During the day, when we were upstairs, there was always somebody keeping guard" 109 .

Similar constructions appeared in other towns and in the countryside as well. An example here could be a hiding place of Rut Leisner and her family. They

106 M. Berland, Dni długie jak wieki [Days Like Centuries], Warsaw 1992, p. 10.

107 H. Hoffman, Z Drohobycza do Ziemi Obiecanej [From Drohobych to Promissed Land], Lublin 1999, p. 70.

108 See e.g. Archives of Jewish Historical Institute (AJHI), 302/103, Journal of Irena Grocher; AJHI, 302/161, Journal of Helena Midner; O. Jagur (I. Grodzińska), Bunkier "Krysia" ["Krysia” Bunker], Łódź 1997.

109 H. Frydman, W getcie i w ukryciu [In Ghetto and in Hiding], "Kwartalnik Historii Żydów" [Jewish History Quarterly] 2004, No. 209, p. 80. 
were Jews from Będzin, who used to live in Godulin near Vilnius. From February 1944, they were hiding at a farmer's place near Godulin. Rut wrote: "He's agreed to hide us on condition that the hiding place would not be located in any of the buildings. He dug a pit, not much larger than a grave, behind the barn with a small opening in the wall, through which we could enter. From the side of the barn that opening was covered with a sheaf of hay and from the outside with a pile of lumber, branches and other clutter. We would stay in that pit day and night. When it was raining - it was wet until the water soaked into the ground. The peasant would bring us some food every few days, just enough to keep us from starving to death"110.

Dugouts built in the woods were popular long-term hiding places as well. In many respects, they were similar to the city bunkers. First of all, almost the same technology was used to build them, but the constructors of bunkers embedded into the city tissue usually had a little easier task. They usually had cellars and construction materials from ruins of buildings at their disposal. In the woods, one had to erect the construction completely from scratch. Aleksandra Bańkowska wrote: "An ability to construct a bunker was connected with knowledge of where to look for good soil, how to dispose of several dozen cube meters of dirt, expertise in carpentry and woodworking, as well as with a necessity of finding tools. [...] If somebody couldn't build a bunker, they would buy a ready one or hire people to build it. People would not only actively buy and sell bunkers, but also spots inside of them"111. Henryk Hoffman and his family were hiding in a forest dugout near Drohobych for a long time. He wrote the following about his experience: "There were eight people in a dugout in a wooded area. It was supported with wooden pit props, like in a mine. It was about three or four meters big and two meters high. There were four bedbug-ridden bunks inlaid with straw and hay, a small tin cooker and one oil lamp. Leveled earth made for the floor. It was an incredible shock for my parents"112.

Hiding in a city or in the country could have various level of "intensity of conspiracy". There were "total" hideouts, from which people would not come out at all. In other cases, when a few people were hiding together, they were segregated:

110 R. Leisner, A jednak cud się zdarzyt [The Miracle Happened After All], in: Losy

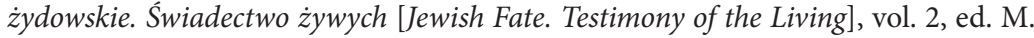
Turski, Warsaw 1999, p. 222.

111 A. Bańkowska, Leśne kryjówki Żydów w okolicach Borysławia w okresie okupacji niemieckiej [Woodland Hiding Places of Jews near Boryslav during German Occupation], mps, p. 6.

112 H. Hoffman, Z Drohobycza... [From Drohobycz...], pp. 81-82. 
members of the group with "better" look, who spoke better Polish and had documents, could go outside, bring food, work. Most often, but not always, those were women, as they were not in such imminent danger of being identified as - usually circumcised - men. Stefan Chaskielewicz wrote about hiding at Mrs. Maria's apartment at Koszykowa Street in Warsaw: "Father never went out. Mother did it relatively rarely. I didn't go out to often either. I had to go out, however, as our financial situation was getting worse and worse. [...] I didn't dare [...] to put myself to any other paid work"113. Deep conspiracy was probably the most frequent model of long-term hiding. Children were often hidden like that, as them going out would bring no benefits, but could be highly risky.

It is noteworthy that a long-term hiding place was dynamic; some solutions were often modified due to various reasons. For example, and intensification of German terror in a neighborhood could lead to making the rigor of conspiracy more severe. Władysław Dov Kornblum was hiding in Targówek district of Warsaw and at the beginning, he could even play with the host's children as a "relative", but later the situation has changed. String of Włodek’s hideouts in one household shows an evolution of a long-term hiding place, which they were trying to adjust to changing conditions: "After the liquidation of the ghetto, a tough period of loneliness and complete descent 'underground' has started. Nobody could know that I'm there, that I exist. The ones who were once told that this relative came to visit from Warsaw, were now told that I went back to my family for good. A period of hiding, mostly under the bed, form morning to evening has begun. [...] Over time the systems of hiding were changed and perfected. For some time, I was hiding in a cellar under a trailer floor, as it turned out that it wasn't so safe under the bed. [...] As long as a visit of a kin or a friend was announced, going down the cellar was not much trouble. [...] I would sit in the cellar when the house was empty too, that is when uncle was at work, aunt at the market and children at school. When they came back, they would release me from the cellar, but as time went by, I have started spending almost the whole days there, even when the family was home. [...] The time of hiding in the cellar was not very long, albeit it was the best place of all to hide during winter. Uncle and aunt came to the conclusion that hiding me home was too dangerous, especially in the atmosphere of horrid terror rampaging in Warsaw in 1943 after liquidation of the ghetto. [...] This is why it was decided that from then on, meaning from summer of 1943, I would start hiding outside the trailer where the whole family lived. In the summer, I used to stay in the so-called burnt rubble. That rubble used to be a

113 P. Chaskielewicz, Ukrywatem się... [I Was Hiding...], p. 56. 
home where 'my' family and other ones lived before the war. It burned down during bombings of 1939 and the family was forced to move to that trailer located 50 meters from the house. [...] This spot was indeed good, but only in the summer and when it wasn't raining. I had to find another spot when autumn set. This new hiding place, the most dependable one, and the one where I have stayed the longest, was located in one of the sheds from a short row perpendicularly adjoining a gate in the fence"114.

Gitla Gerwic from Volodymyr-Volynskyi depicts a similar experience. Gitla was hiding in a shelter in the Volodymyr Ghetto from $13^{\text {th }}$ December 1943 to $2^{\text {nd }}$ January 1944. Later, she has decided to seek help with a Pole she knew. Evolution of her hiding place lead to the state of total conspiracy in extremely hard conditions. "He dug a hole in a room. It was a one-story house. I stayed in this hole with two other people till July. In the first two months, we were going up to the apartment in the evenings, but later, when the Germans were sweeping the apartments more vigorously, our host covered the hole altogether, leaving just a small mouth to breathe through, where he would sometimes put a piece of bread or some water. We stayed in one position the whole time and dealt with our bodily functions like that"115.

When classifying hiding places from the perspective of the planned time spent therein, we have to remember that fortuitous cases of being saved in the firstchoice hideout were scarce. It was also rarely possible to truly plan for something in war-time reality. Usually the subsequent families on whose doors the wanderers knocked would simply refuse to accommodate them for a long period of time. Wacław Iglicki, who jumped out of a train to Treblinka near Łuków, tells the following story: "Indeed, the people were helping out. I have to objectively say that they were not skimping on bread or things like that. But there was a problem with spending the night. People were afraid. They wouldn't really give one a place to sleep or stay for a long time. [...] That's what we did: at night, when everybody was sleeping, we would sneak in somewhere, to a pen, a barn, and somehow waited it out in there. Just to keep the owner in the dark. Or maybe he knew and just looked the other way?" 116 . Instead of hiding in the desired longterm hiding places, people had to make do looking for one temporary hideout after the other. I will try to describe such an experience in more detail in the Wandering - looking for a hiding place part of this book.

114 W.D. Kornblum, Ostatnia latorośl [The Last Offspring], Warsaw 2000, pp. 61-64.

115 G. Gerwic, Relacja [Testimony], in: Życie i zagłada... [Life and Holocaust...], p. 611.

116 Interview with Wacław Iglicki, mps. 
Keeping a long-term hiding place - either an independent or assisted one depended on a vast number of factors. Organizing everything so that one could spend a long period of time in a hiding place, required an enormous effort, ingenuity and luck. The human factor was the most important. It often happened that just one ill-disposed person, one surprise visit or one instance of reckless behavior put the hiding place in jeopardy. Regina Kenigswein was hiding with her children at Jan Żabiński's place in Warsaw. She gave an account of such an event: "Seamstresses, washwomen and other people kept coming there. The door would never close. When I was already downstairs, somebody would walk around at night and talk, I didn't really know what was going on. Maybe those were Jews, maybe not Jews, I don't know. Anyway, I was watching the children like a hawk. But I'm only human and one time my little Stefcia bolted out of the room. A seamstress who knew us was there and asked the director 'What is Sobol's granddaughter doing here?' and then, sadly, I have blown my cover. The director came to me and said: 'My child, unfortunately you were not careful and you will have to leave this house. But he said it in such a way that I felt he would do anything for that to not have happened"117.

Often the reason to expel the residents of a hiding place was a conflict with the owners of an apartment. Sometimes the owners did not want to hide Jews anymore, for example for economic reasons (they estimated that the money paid by the people in hiding do not compensate inconveniences and threats connected with their presence home). Michał Głowiński wrote about such a situation. His father was staying for some time with a certain farmer "After some time, the farmer realized that hiding a Jew at his place in 1943 puts him in grave danger and he demanded a higher payment. But it did not end there. He had - grant it - a pretty rational idea. He told my father that, as a Jew, he will surely be exterminated anyway, but it would be bad if he [the farmer] would suffer along the way or even lose his life. The consequence of this disillusioned outlook on reality was not an eviction notice, however. [...] The farmer announced that it would not make sense if the father would simply die just like that, since he has to be killed anyways. The best solution would be if the farmer brought him to the Germans, namely to the nearest military police station. Admittedly, the father will be killed, but nothing will happen to the farmer, even more, he will make a profit, as they will give him a reward. [...] The father had no illusions and no other choice: he had to take to flight, even if it meant running into the void"118.

117 Archives of Yad Vashem (AYV), 03/2888, Regina Kenigswein.

118 M. Głowiński, Czarne sezony [Dark Seasons], Warsaw 2002, pp. 89-90. 
Other, less serious dangers and difficulties awaited the residents of bunkers, for example those hiding on the territory of the Warsaw Ghetto after the collapse of the Warsaw Uprising in 1943. Diminishing food supply and water shortages often made the desperate people in hiding, who were on the verge of starvation, to leave their sanctuary. Consequently, any hiding place intended as a long-term one could in reality turn out to be just a temporary hideout, a pit stop. Worst case scenario - it could turn out to be the last refuge, from which there was no escape or rescue anymore.

\section{Independent-assisted hiding places}

Another category I believe to be essential was distinguished based on a criterion of presence or lack of outside aid. To precisely describe this category, one has to realize the complexity of the phenomenon of helping the hiding Jews. Barbara Engelking wrote: "A decision to help Jews was not easy either. Even though it was punishable by death, there were Poles who were courageous enough to shelter Jews. Some did it for humanitarian or religious reasons, some - for profit. Harboring a Jew required not only bravery, but also patience, tactfulness, helping them with little things, which sometimes turned out to be insoluble problems such as a toothache or a need to see a doctor. Sometimes an impulsive decision to help someone turned into being forced to spend months and years with someone who turned out to be plainly unpleasant, boring or stupid"119.

First, we should acknowledge graduation of assistance provided to the people in hiding. Szymon Datner distinguished two forms of help: ad hoc aid (feeding someone once, lending clothes etc.) and sustainable aid (long-term care) ${ }^{120}$. We can expand this classification. It is impossible to identify all possible forms of helping. I will enumerate only the most obvious ones, which were mentioned by authors of testimonies most often. At one end, we can place kind tolerance for a person trying to hide on their own, not noticing this person's hideout and therefore enabling it to continue existing. Forms of help requiring an increasing level of involvement are: one-time feeding, providing overnight accommodation, financial aid, helping with trading or selling things, assistance in finding or building a shelter, obtaining forged documents, regular feedings, up to providing someone with a place to stay in one's own home and completely supporting someone.

119 B. Engelking, J. Leociak, Getto warszawskie... [Warsaw Ghetto...], pp. 699-700.

120 P. Datner, Las sprawiedliwych. Karta $z$ dziejów ratownictwa Żydów w okupowanej Polsce [A Forest of the Righteous. Page from History of Saving Jews in Occupied Poland], Warsaw 1968. 
Such an approach to the issue, however, requires a strict criterion of division between the victims, i.e. hiding Jews, and the helpers - usually Poles, generally non-Jews. This distinction is a simplification. Majority of cases most likely fallows this pattern. However, not everybody in hiding was indifferent to the fate of their companions or other Jews. Jews in hiding were helping each other as well. The simplest form of such help was letting somebody into one's hideout. Such situations occurred e.g. in woodland dugouts or bunkers on the territory of ghettos, where there was no non-Jewish owner of a flat, home or property who would have a final say concerning the number of people in a hiding place. There have been times that a person operating with "Aryan papers" or simply reasonably freely moving on the outside would support the other members of the group.

Story of Leon Guz, who was hiding in Warsaw in a tenement at 64 Targowa Street ${ }^{121}$, could serve as one of the examples here. His wife, Alicja, after getting a kennkarte, rented a flat herself, in which four more people hid along with Leon. In the flat they have built "a hideout within a hideout" in case of an intrusion by uninvited guests. Alicja would take care of everything, which required leaving the house: she would buy food for five people, get firewood and water, as well as empty the bucket with excrements. Here is the outlook of a situation of Rut Leisner and her parents, who were hiding with farmers in the countryside: "Sylwester and his family were so poor, that even a piece of bread and watery soup they shared with us were a heavy burden for them. Father was trying to help by going out at night, especially when it was dark, to farmers leaving far away, as far as possible, so as not to compromise our shelter, and begging for any food, for anything they could give him, but also to get information on what was happening outside" 122 . The situation was similar when some families split, each person was hiding at a different spot and they needed a "connection", but also when people located in a safe place were helping other members of their family find a hideout.

Family camps and other forms of surviving in groups in the woods were a special case of such aid. "According to Encyclopedia of the Holocaust, family camps mean groups of Jews hiding in a forest, comprising of few to a dozen or so families, with a unit of armed men supplying the camp with food and protecting it from danger. The definition is stressing strong connections of the camps with Jewish partisans"123. Such camps were most often located in forests of central

121 L. Guz, Targowa 64 [64 Targowa Street], Warsaw 1990.

122 R. Leisner, A jednak... [The Miracle...], p. 217.

123 A. Bańkowska, Leśne kryjówki... [Woodland...], p. 1; see Y. Arad, Family Camps, in: Encyclopedia of the Holocaust, ed. Y. Gutman, Jerusalem-Tel Aviv-New YorkLondon 1990. 
and eastern Poland and in the Borderland. The biggest family camp, led by Shalom Zorin in Naliboki Forest, consisted of 800 people $^{124}$. Other concentrations of Jews in forests, which we cannot call family camps, were characterized by a highly developed network of internal help as well. For example, in Boryslav forests "people were walking about the forest, getting to know each other, selling, trading hiding places, going out to the town and to the camp. There was a small but constant traffic between the forest and the town. Blima Haberman recalls being a connection between family members where some were in the forest and some in the camp, as she herself was an inmate in the camp, but had a pass to go in an out to the town"125.

When it comes to long-term hiding places, a broadly understood psychological help was an important issue. It was intangible, immeasurable, yet indispensable. It could come either form a fellow person hiding or from the outside. It is a question of helping one to persevere in a hideout: on the one hand, easing the stress, improving emotional condition of the hiding person, and on the other hand, breaking the insufferable monotony of hours that all looked the same. Everything counted: companionship, kindness, conversations, keeping busy. Motif of information connection with the world is very frequent in the testimonies: news "from the city", gossips and rumors, news from the front, i.e. supplying newspapers or communicating the content of radio transmissions.

As we can see, the scope of help provided to the people in hiding is especially broad, and, as it is not my main topic, I shall refrain from systematic and detail description thereof. To allow for a fairly clear division, I propose to recognize the assisted hiding places to be the ones the existence and operations of which required involvement of a third party that was not hiding in a given place. Therefore, hiding places were individual only if they were created by the hiding people themselves, where the hiding people took care of their needs on their own, and, depending on the circumstances, to a large extent decided their fate themselves.

We can therefore formulate the following hypothesis: majority of long-term hiding places were assisted. Aside from particular cases, it was generally impossible to survive in hiding for months without contact with the outside world. In the number of independent hiding places, we can mainly list the temporary hiding places (although not all of them) and long-term hiding places in unpopulated

124 Polski słownik judaistyczny. Dzieje, kultura, religia, ludzie [Polish Judaism Dictionary. History, Culture, Religion, People], prepared by Z. Borzymińska, R. Żebrowski, Warsaw 2003.

125 AJHI, 301/1091, Testimony of Blima Haberman; A. Bańkowska, Leśne kryjówki... [Woodland...], p. 8. 
areas, where outside help simply could not arrive for objective reasons. Such hideouts included e.g. locations of Robinson Crusoes of Warsaw on the territory of the demolished ghetto, or hiding places in ruins during the Warsaw Uprising and after it was suppressed.

\section{Individual hiding places (independent)}

The majority of hiding places improvised in face of a sudden risk can be classified as independent. An attempt to hide from Germans, who unexpectedly showed up in a forest is described by S. Arońska, citizen of Zofiówka (before the war in the Volhynian Voivodship). Arońska was hiding in a shelter she prepared herself in a forest along with her mother and sister. They would sometimes come out of their hideout. "Thus, the winter was slowly passing. The forest was turning green again and who knows, maybe all three of us would have lived to see liberation, if it wasn't for two Germans, who suddenly drove up to us when we were picking up twigs. I saw them first and that's why I managed to climb up a heavily branched fir $[\ldots]$. I sat there for three days before I finally had to go down. I dragged my dead mother to the shelter and went wherever my feet would take me"126.

A great number of testimonies gives descriptions of various ways of hiding in ghettos during displacement actions. I shall give only one example - testimony of Izaak Rozenberg from Łódź who survived "szpera" along with his family in September of 1942 thanks to a series of temporary hiding places: "We were in despair at home; we had an 8 years-old brother. When they got to our district, we heard a Jewish policeman shouting 'Alle herunter' at the gate. Mother was so scared that she didn't even take off her coat and went downstairs like that. In the last moment, I got an idea and hid my brother under a straw mattress with a help from my sister. [...] On the street, we saw that there were only Jewish policemen there, no Germans. The thought that they had no guns gave me strength. I left my sister and started running towards another street, where they were already done with the roundups. I hid in some yard. [...] The Germans [...] started repeating rounds in the districts. [We] were expecting them to come for us again. We have decided to hide on the roof. We quietly went to the attic before the dawn, so the neighbors wouldn't hear us. You had to use a ladder to get to the attic, there was a flap in the attic ceiling, and we pulled up the ladder after we went up. At 10 the second shakeout took place in our building. Neither Jewish police, nor Gestapo was suspecting that there was any attic and that somebody was hiding there. We

126 P. Arońska, Relacja [Testimony], in: Życie i zagłada... [Life and Holocaust...], p. 613. 
wouldn't go down the whole day, because we didn't want the neighbors to suspect that we have a hideout. We came down from the attic when it got dark"127.

Some forest-based hiding places can be classified as independent. People who escaped ghettos, transports to camps or places of mass execution, would often look for a permanent hiding place for a long time, hiding in forests or other uninhabited areas on their own. They would find food on their own, not counting on help from anybody, as nobody knew they existed. For example, this situation was described by Rywka Potasz, citizen of Zofiówka: "We were hiding in the forest for a few days. We had nothing to eat, we barely escaped with our lives, barefoot. It was so cold that we couldn't sleep, we were huddling together. I was holding my children, they were holding me, but we couldn't sleep. We picked up leftover blueberries and huckleberries. Not very nutritious food. Nobody is complaining, but I see that my children are dying of hunger and at nights of cold"128. This situation could not last long; a few days in a forest are rather an overly prolonged time spent in a temporary hiding place. Rywka's husband was soon sent to a nearby village to get in touch with Poles they knew. Later, when the Potasz family was preparing a proper dugout for winter, regular outside help turned out to be indispensable.

Long-term hiding places on a territory of a ghetto (or a devastated city) should be classified as independent. This especially concerns big cities. The highest number of accounts describes bunkers in Warsaw. People living in bunkers, hideouts in tenements or ruins were cut off from the world and thus from any kind of help. They could contact people living in other hiding places located nearby, but they were often not even aware of their existence. As it was stated by Jacek Leociak: "The first period of living in ruins lasted from the beginning of the Ghetto Uprising to the beginning of 1944, and the second period - from the fall of the Warsaw Uprising to liberation. In the first period, the ruins of the closed off district were inhabited by a dozen or so thousands of Jews. [...] In many cases these were armed groups of the so-called gruzowcy [ruin troopers] who would foray against Germans or resist formations raiding the ghetto with force. Sporadic fighting continued in June and in the beginning of July of 1943. In the second period, few hundreds of people remained not only on the territory of the former ghetto, but in the ruins, all across the capital. [...] The name of 'Warsaw's Robinson Crusoes' stuck to them" ${ }^{29}$. Hiding places of "gruzowcy" and

127 Account by Izak Rozenberg, "Kwartalnik Historii Żydów” [Jewish History Quarterly] 2004, No. 211.

128 R. Potasz, Relacja [Testimony], in: Życie i zagłada... [Life and Holocaust...], p. 616.

129 B. Engelking, J. Leociak, Getto warszawskie... [Warsaw Ghetto...], p. 760. 
"Robinson Cruzoes" were essentially similar. In fact, the only difference was the district they hid in - which, after the uprising fell, wasn't of that much significance anymore, as the devastated city became similar to the ghetto, which was destroyed just one and a half year earlier. I shall cite passages from testimonies of "Robinson Cruzoes" in Chapter 2. I will only mention here that those were probably residents of hiding places characterized by the most extreme conditions. They used bunkers prepared beforehand, but also ruin crevices, basements and remaining buildings. Some were relatively lucky to stay in normal apartments, as was the case of Bronisława Markiewicz-Boraks who lived with a few members of her family at Helena and Wacław Dutkiewicz's place at 55 Aleje Jerozolimskie Avenue since the beginning of 1943. She recalls: "The Uprising in Warsaw broke out on $1^{\text {st }}$ August 1944. Mrs. Helena was at a summer resort in Swider at the time. Mr. Dutkiewicz brought us a pitcher of water and a loaf of bread and said: It will all blow over in two or three days. He left the flat and went to Swider too. We were in a new type of hell. The home was close to the Central Railway Station which was under constant bombing. We wouldn't go out, we were still trapped, because there was a Soldatenheim next to us and there were Germans everywhere. The whole neighborhood was swept clean off Poles. [...] During the days, we were laying there motionless and at nights went looting apartments looking for food. There was no light or water. [...] Houses were burning down next to us and we wouldn't go out"130. This group of Jews stayed in the apartment at Aleje Avenue until $17^{\text {th }}$ January 1945.

After the Warsaw Uprising, in the destroyed Warsaw alone, according to various calculations, there were few hundreds of people hiding, majority of them Jewish. Many of them died in ruin cave-ins, other died of diseases, exhaustion, cold, and hunger or got killed. Aside from extremely harsh living conditions in the ruins, constantly searching for food and water, the "Robinson Cruzoes" would also experience loneliness, not being aware of events in the world (e.g. they did not know what happened after the uprising failed, what was going on at the front, or even what was transpiring in the same city, in a different district). The situation of people hiding on their own was the most severe, just like the one of Władysław Szpilman, the most famous "Robinson Crusoe". They could only rely on themselves with practical aspects of everyday life, and had to, for example, somehow fill the endless oceans of time.

130 AYV, 03/2818, Bronisława Markiewicz-Boraks. 


\section{Assisted hiding places}

When describing assisted hiding places, we have to introduce a division between organized and individual help.

There are many studies addressing the subject of organized help for Jews ${ }^{131}$, thus I shall refrain from elaborating on that subject here. We have to also note the sadly limited outreach of organizations, which would not reach all the regions of occupied Poland. Organizations helping in finding a hideout and sustaining it further were making the lives of people in hiding easier to a large extent, but their impact was not far reaching enough to change some constant conditions and experiences connected with the phenomenon. In a sense, the organized help can be understood as a support for individual aid. Despite an increase of sense of security guaranteed by the protection of an organization, the Jews provided with addresses and money were still marching into individual people's lives, taking space in their homes and interacting with their hosts just like the ones who found and sustained their hiding places on their own, or with help of neighbors or friends.

Hiding children in monasteries and orphanages was a separate issue. They would usually stay there with "Aryan papers". There were cases, especially in Borderland monasteries, when the nuns decided to keep a child with a new surname, but with no papers. Therefore, monasteries were not hiding places as defined for the purposes of this book. But in this long-term hiding of Jewish identity there also were moments when one had to hide in a physical way as well, descend to "a hideout within a hideout": "Each house had their own system in place in case of German searches: putting on bandages, walks, quick games, lockers. Marysia in Przemyśl got a key to a nearby church from sister Bernadeta. She was to hide in a closet in the altar if the Germans came searching"132. Eva Kurek cites testimony of Zofia Szymańska who describes how the nuns hid a few girls in a closet with habits, as well as a memory of Leia Balint, who was hid as a little baby in a woven basket and covered with eggs.

131 See e.g. T. Prekerowa, Konspiracyjna... [Conspiracy...]; K. Iranek-Osmecki, Kto ratuje jedno życie... Polacy i Żydzi 1939-1945 [Who Saves one Life... Poles and Jews 1939-1945], London 1968; D. Stola, Nadzieja i zagłada. Ignacy Schwarzbart $\dot{z} y$ dowskiprzedstawiciel w Radzie Narodowej RP (1940-1945) [Hope and Holocaust. Ignacy Schwarzbart - Jewish Representative on the Polish National Council (19401945)], Warsaw 1995.

132 E. Kurek, Dzieci żydowskie w klasztorach. Udział żeńskich zgromadzeń zakonnych w akcji ratowania dzieci żydowskich $w$ Polsce $w$ latach 1939-1945 [Jewish Children in Monasteries. Participation of Female Assemblies in Saving Jewish Children in Poland], Lublin 2001, p. 58. 
Among temporary hiding places there are, of course, examples of assisted hideouts. Teresa Prekerowa wrote extensively on "transition places" supported by conspiracy Council to Aid Jews in Warsaw ${ }^{133}$. There are many examples of individual help mentioned in the testimonies. Those could mean showing someone a place to hide for a while, feeding someone or giving them a place to stay for one night. The first case can be illustrated by words of Ita Dimant, who found a hiding place in a basement during a blockade of a home in the Warsaw Ghetto thanks to a random person. "Jump into that basement, miss - the doctor said. [...] I slither in through some narrow hole to a half-caved-in cellar - and I hear whispers coming from somewhere. I grab on the walls in the dark and find a door - the whispers go silent. I fear I'll scare somebody hiding and go back to a hole making for a window"134.

Anna Federbusch-Ophir told a story of how she was trying to hide with her sister after escaping Rokity labor camp in Tarnopol. They found a place in a nearby garden and then tried to sneak into a farmer's home. "In the meantime, we have noticed a few youngsters advancing on us. This time I lost hope fearing that we will be exposed after being tracked down by children. How happy we were when the children approaching us shouted: - Miss! They can see you from far away. We were touched when the children brought huge leaves called 'plantago' and covered our faces themselves"135. Estera Michalson-Choniak, in turn, describes her escape during a liquidation action of a small-town ghetto. She was helped by another Jewish woman who was temporarily in a better situation. "I went down the street and run into a young Jewish girl, Basia Abramowicz, when I was leaving the ghetto. She worked for Germans and had an 'attestation'. - Estera, what are you doing here? Hurry and come to my place! - she said emotionally. That night I safely slept in her bed"136.

A vast majority of long-term hiding places are examples of shelters which were assisted to some extent. To clarify that, I have chosen one criterion to determine two types of assisted hiding places. It is a criterion of physical (but also emotional) distance between the hiding and the helping people. We will separately examine hideouts prepared in somebody's home, flat, or on a farm. I have called them "under the same roof". (Naturally, people hiding at somebody's place

133 T. Prekerowa, Konspiracyjna... [Conspiracy...].

134 I. Dimant, Moja czastka... [My Piece...], p. 56.

135 A. Federbusch-Ophir, Relacja [Testimony], in: Życie i zagłada... [Life and Holocaust...], p. 367.

136 E. Michalson, Relacja [Testimony], in: Księga Żydów ostrołęckich [Book of Ostrołęka Jews], Ostrołęka-Tel Aviv 2002, p. 417. 
would often be aided by third parties and not only by their hosts). The second type of hiding places are the ones organized comparatively on one's own, in an "independent" spot - in a forest, ruins; their operations were based on outside assistance of variable intensity. I call this type of a hiding place "at a distance". The help did not mean sharing all life aspects; the relations would be generally less tight and less committed. In case of the hideout being exposed, the person helping was not risking as much as in the case of hiding places "under the same roof".

\section{Hiding places "under the same roof"}

They can be divided according to a place that was provided for the hiding people in a given household. Those included separate rooms or permission to move about the whole apartment (with "a hideout within a hideout" in case of guests or neighbors arriving), permanent hiding places on attics, in basements, under floors, from where the hiding people would be let out only occasionally, in farm buildings (sheds, barns), or arranged in a pen (for example "bunkers" dug out in a yard). Depending on a place, the people hiding were more or less involved in the hosts' lives. They could spend whole nights and days in direct proximity to their hosts or see them just once a day, for example when the food was delivered. As I wrote in the part on long-term hiding places, a place of a hideout could have been subject to change. This change would usually be for the worse, leading the fugitive into more cramped and limited spaces.

A temporary hideout "under the same roof" is a separate topic - it would mean offering someone one-time overnight stay at home or on a farm. Such a hiding place would not interfere with the life of a family to a big extent, would not require special preparations, and would only be just a pit stop for a hiding person. Therefore, I shall further concentrate only on issues connected with long-term hiding places.

Help involving hiding someone in one's own home is one of the hardest experiences, both for the host and the hidden person. The situation was surely made easier by bonds of friendship between the two sides, but even the most harmonious relationship could deteriorate over time when functioning in such a delicate and risky arrangement. Fear was the most important element of the experience of a hideout "under the same roof". Both sides feared the same things - the hiding place being compromised and the death penalty connected thereto. However, it was usually the host who had the initiative and the final say. The hosts could throw "the guests" out of their homes at any moment (or even denounce them to Germans) and thus reinstate the home's status quo from before the Jews looking for shelter showed up. There was no escape from the fear for the hiding people, 
it was accompanying them everywhere they went, regardless of a hideout. While in a situation of a conflict with the host, bad conditions or any other hardship, the person hiding could theoretically always leave as well, but it would entail a need to find another hideout. It was not an easy decision to make and that is why it often happened that people would for months stay in stalemate, terrible conditions, knowing that they are being cheated, used and treated badly. Disproportion of power and means forced a hierarchical link of dependence, sometimes leading to situations in which the people hiding would find themselves at the mercy of their hosts. Being vulnerable like they were, they could end up on the bottom of domestic hierarchy and become a scapegoat for the family.

A lot played out on the scene of economics. Emanuel Ringelblum has already introduced a distinction between "idealists" and people hiding Jews in exchange for money. I shall follow Teresa Prekerowa in differentiating between hosts "who could simply not afford such selflessness [...] and would not take more from their Jewish tenants more than they had to" and those who demanded increasingly steep fees. "There were, however, cases when people wanted to make a fortune on keeping Jews, whose compulsory situation of granted shelter was exploited. These people demanded enormous amounts of money and ruthlessly executed the dues. It is hard to determine the extent of this phenomenon"137. However, even with relatively small sums of money, a potential for abuse easily arose, as well as for exploiting the situation, raising the price of "rent", cheating on shopping, intercepting money or things delivered from the outside for the people in hiding. Most of all an arrangement based solely on finances would inexorably fall apart when the money runs out.

But there is more just than fear, power and money. The phenomenon of living in somebody else's home and being a part of that somebody's life was aptly analyzed by Janina Bauman: "Hiding in people's homes meant not only loosing contact with the outside world, a necessity to obey cumbersome rules, and constant danger. Being trapped in four walls, condemned to idleness, we were also deprived of our own lives. Men and women, who gave us shelter, or even their children, had their everyday business to attend, problems to fix, little trouble and serious worries, some achievements and failures, moments of joy and sadness. Our existence was empty. We simply went on biding our time. Stripped of our own lives, we vicariously lived through others. We shared other people's joys and sorrows. We cared about completely different things in each home, depending on what was important for our subsequent hosts. I needed a long time and a few

137 T. Prekerowa, Konspiracyjna... [Conspiracy...], p. 184. 
hiding places to find out that our presence was something more than a great danger, everyday inconvenience and a source of extra income for our hosts. The fact that we lived with them was influencing their moods and behavior as well, amplifying their noble or vile side. Sometimes it drove a wedge between the family, and sometimes it brought it together in common effort to help and to endure"138.

When people are taking strangers or acquaintances under their roof, they have to accept changes, breaking of routine, and imbalance in a once stable system it entails. Presence of those people at home or on a farm was connected with numerous unforeseen circumstances, complications of technical (how to set up a hiding place, buy more produce without drawing attention to oneself, organize everyday life), but also emotional nature: "affairs and threesomes, which had dramatic finales for everybody. Pregnancies and children born in hiding occurred as well"139. In turn, when adapting to living conditions in a given home, the person hiding had to accept the rules set by the host, toe the line, pay an agreed upon sum for the stay or work for the host, abandon previous habits... And most of all, become as little visible and disruptive element of the domestic system as possible, get on the host's good side and thus aim to survive another day in relative safety.

Staying in one hiding place for a long time was not always possible. Etka Żółtak, an escapee from the Czyżew Ghetto, reported: "When I heard the sound of shooting in the evening of November $1^{\text {st }}$, I realized that the Germans were clearly coming back to take out the Jews. At that point, I have decided to run. [...] I went towards a village which was 9 kilometers outside the city. It was Helenów, the Wysokie Mazowieckie County, the Białystok Voivodship. I went to a home of a farmer I knew, Franciszek Świątkiewicz. I asked him to hide me for a few days. He didn't want to do it because he feared the consequences for himself. When I came to him, he let me stay until November $12^{\text {th }}$. He would help me until then. I was very happy and wasn't thinking about the longer run at that point. I went down a basement and sat out those days in there. In the evenings, I would go out and enjoy the street and fresh air. There were no windows in the basement and there was straw everywhere. I was fed at 4 in the morning and 10 in the evening, when there were no strangers wandering about. On November $12^{\text {th }}$, the good man told me to leave. Fearing Germans, I went to another farmer from the same village. He was called Jan Bogucki. I knew there was an empty room in that home. It had a lock and a double wall. I begged the goodwife of that home to hide me, to

138 J. Bauman, Zima o poranku [Winter in the Morning], Cracow 1989, p. 184.

139 B. Engelking, J. Leociak, Getto warszawskie... [Warsaw Ghetto], p. 701. 
let me stay. I told her that if she wishes so I could knit anything she wants. Only then she said that I could stay a month at theirs" ${ }^{140}$. Sadly, the woman showed Etka the door ten days later, so she had to look for shelter in a forest, and later, after a failed attempt to return to Boguckis, she's decided to change her hiding strategy: "I have walked away, started wandering the villages. Having nowhere to go, I have decided to go to Warsaw and try and get Polish papers"141.

Sometimes accepting somebody under family roof was conspired twofold: when one member of a family offered help, without telling the others. Then the hideout would become that member's secret as well, it had to be protected not only from a potential outside threat, but also from "their own people". Rajzel Gerstenman was in hiding in Lublin at Fabryczna Street: "My brother went back to the Christian woman's place, where I have previously slept. After a long predicament, she's decided to keep us in a shed in her yard. We stayed with this lady for 18 months. Not even her daughter knew that we were at her mother's. Our good lady gave us food through ajar door"142. A group of female escapees from a camp hid in a farm lady's barn without her knowing: "We're running our feet off and suddenly we see a house with a barn behind it. We make a swift decision, jump into the barn, climb up a heap, and crawl under hay and hide there. After diving into the hay, unseen by anyone, we stay like that for two days. We have food - maggoty peas from the provisions packed beforehand for the road. It's dawning and the third day of our tragic freedom is upon us. Suddenly one of the girls says in Polish: 'Łejke, we can't just lie here doing nothing, we are going to starve, and that's a bad deal'. Those words were a signal to dress up and get out of the hay. We clean ourselves up, sew up red patches, so that nobody would figure out where we were from, and quietly come out of the barn. Polish woman, the owner of the house and the barn, had no idea we were in her barn"143. When the farm woman found the girls, she fed them and let them stay.

The bonds that used to formulate between the people in hiding and the hosts in a hideout "under the same roof" could become very strong, especially when the Jews' stay would prolong in somebody's home. Those relations were rarely conflict-free and entirely positive. Staying together on limited space, sharing fear and often poverty, people had countless excuses for strife and quarrel. A hiding place like that could also be a scene for physical or psychological violence, domination, economic exploitation. Simultaneously it was the simplest

140 AJHI, 301/545, Testimony of Etka Żółtak.

141 Ibid.

142 AJHI, 301/487, Testimony of Rajzel Gerstenman.

143 AJHI, 301/701, Testimony of [Łejke] Kopilewicz. 
and greatest good deed one person can do for another - to directly save a life. A ravel of conflicting feelings, sensations, and relations that was a hideout "under the same roof" is a topic for another study. After reading many texts describing relations between the people hiding and the hosts I can risk one generalization (or rather an intuitive conclusion): being hidden by someone, despite better living conditions and more certainty in existential issues - could have often been more psychologically difficult to bear than a relative independence of people benefiting from help in an assisted hiding place "at a distance". The latter, which can be called "people who hid" (using active, instead of passive voice: "were hidden"), perhaps had a sense of having more of a say when it came to their fate, a greater sense of being the causative ones (I write more on the subject in Chapter 4). Perhaps they were also more afflicted with loneliness, uncertainty of tomorrow; looking for help "at a distance" was also a tough challenge compared with aid present on daily basis in a hideout "under the same roof". I do not wish to compare the extent to which hiding in one type of a hideout was harder than in the other, as it depended on too many factors. However, it seems that by having a more casual relationship with the people helping, diversifying the sources of aid, not putting themselves in a situation of absolute dependence from just one person or family, a person hiding "at a distance" had more maneuverability. Looking for an explanation, we can reference a classical exchange network analysis by Richard Emerson ${ }^{144}$, who identifies the basic processes of social exchange to be using power and compensation. In a situation where one person is clearly dependent on another, the second person has an advantage of power - this is how an attitude of the helping toward the hidden looks. This creates potential for abuse, when the helping person might demand and increase of costs in exchange from the hidden person. A person entangled in such a relation of subordination tries to balance out the exchange process. One of the balancing operations is expanding alternative sources of necessary supplies - this is how the monopoly of a helping person is broken. This operation was probably easier in case of people hiding "at a distance". Of course, it did not mean that their lives were easier or safer, but the circumstances and threats were slightly different.

\section{Hiding places "at a distance"}

A hiding place "at a distance" is a model of help that requires less commitment from both sides and is therefore less risky. It was comparatively easy to extricate

144 See. J. Turner, The Structure of Sociological Theory, Homewood 1978, pp. 283-290. 
one from relationships developed in such cases - a helping person could simply stop coming and disappear from the lives of the hiding people. They could, in turn, theoretically seek help from someone else. But preeminently the people living in such a hiding place, despite being more on their own, had more freedom to operate and make decisions. A person helping them, most often by bringing food, could be remembered as a positive character, a guardian angel or a kind soul. Because the field of common action and conflicts of interest was much smaller than in case of hiding places "under the same roof", the potential for conflict was smaller as well. A person helping was merely a guest in the space of a hiding place, of which the actual landlords were the hiding people themselves.

Hideouts in a forest are a classical pattern of assistance "at a distance": people looking for shelter join a group of other hiding Jews or prepare a dugout themselves. Locals from a nearby village, town, khutor or settlement deliver food to them on more or less regular bases. Sara Najter, who used to live in Przemyszew near Ostroh in the Volhynian Voivodship used to hide this way: "An old Ukrainian married couple lived near the forest in khutor. They took pity on us and often gave us a bit of hot food for my children. Good, God-fearing old people. Till this day I feel bad that I don't know their names. I used to call them grandpa and granny. We survived a good part of winter that way"145.

Zofia Dulman, who lived on Aryan papers, among other places, in a Polish settlement of Adamówka in Volyn, helped other Jews herself: "Jews, who were hiding in a forest, came to us one day. Away from cities they would sometimes dare to visit Polish villages, where they would get some field work and food. My hosts, decent people, fed them and I kept putting butter, milk and cream onto the table, happy to see Jewish faces. After going back to the forest, they told their companions about me, saying that some decent Polish woman fed them"146. In this case the help was reciprocated: "When they came the second time, I told them, that I was Jewish and made a deal with them that if it gets dangerous, I will run away to them, to the forest. They took me to their hiding places in the forest, underground, and showed me a way leading to them"147. Zofia was in danger not only because of being Jewish, but also because she was a Pole. When armed Ukrainians came to the settlement to shoot Zofia, she fled "to the forest, to Jews", where she would hide for the next two months.

145 P. Najter, Relacja [Testimony], in: Życie i zagłada... [Life and Holocaust...], p. 596.

146 Z. Dulman, Relacja [Testimony], in: Życie i zagłada... [Life and Holocaust...], p. 578. 147 Ibid. 
At times help in organizing a hideout was invaluable. Mosze Gildenman mentions a group, who was planning to escape from a ghetto in Korc (the Volhynian Voivodship) in autumn of 1942: "Gilderman was able to assemble a group of eighteen people, who started preparing for an escape to the forest. They have contacted a farmer, Vasilij Kowalec, who lived at the edge of the city, near the road to Rivne, and who helped the Jews a lot. He confided in him about the plan. The group held meetings at Kowalec's place. They have decided to escape the city in a critical moment and their rendezvous point would be the home of Vasilij Kowalec"148. Only 12 people got to the agreed upon place and went to a forest from there. After some time, the hiding Jews formed a partisan group.

A story of Szewach Weiss and his family is a unique example. It is, in a way, a combination of both types of assisted hiding places. The Weiss family was hiding in their shop, in a cubbyhole built by Szewach's father. To stay alive, however, they needed to ask for help. They survived in the care of Mrs. Lasotowa, who moved in to the same home, therefore transforming an "at a distance" hiding place into "under the same roof" kind. Weiss said: "Then we moved to a new hiding place prepared by my father. He's created a room no wider than $60 \mathrm{~cm}$, but very tall, all the way up to the ceiling. It was between the wall of our shop and the storage, behind the cupboards. We hid in there. There were nine of us: parents, sister, brother and me, my mother's sister with her husband and son, and our neighbor, Bachman. [...] My father prepared it well. First of all, he made bunk beds on top of each other, going all the way up. We would practically spend all days lying down. We asked Mrs. Lasotowa to move into our home; she would prepare food for us and serve it through a sort of small secret doors, it was a kind of cupboard, you'd crack open its door - and that was an entrance to our hideout. Many years later, when I was in the Netherlands and visited Anne Frank's home I saw that her father came up with the same idea with a double wall. Literally, the same design! But Anne Frank didn't survive, and we did. Mostly thanks to Mrs. Lasotowa. She gave us bread, sometimes a bit of some soup, tea, potatoes. But we are talking about an ordinary, everyday life, after all; excrements were the biggest issue in that situation. We had a bucked and Tadek Potężny, son of our other neighbor, a young lad, would take it out every three days and rinse it in the river. It was a true sacrifice and bravery on his part! He had to do it early in the

148 M. Gildenman, Relacja [Testimony], in: Życie i zagłada... [Life and Holocaust...], p. 574. 
morning, so that nobody would see him, because the Germans would immediately figure it out"149.

\section{City, countryside, no man's land}

Decree of $12^{\text {th }}$ October 1939 resulted in creation of General Government (Districts of Cracow, Lublin, Radom, Warsaw, and later the District of Galicia). This is where ghettos were created the earliest. Western territories of Poland were incorporated into the Third Reich by a decree of $8^{\text {th }}$ October 1939 (Białystok district, Upper Silesia Katowice Regierungsbezirk, Reichsgau Wartheland Łódź Regierungsbezirk). By order of Himmler from $30^{\text {th }}$ October 1939 a majority of local Jewish population was deported to cities and towns outside the Reich. After the beginning of German-Soviet war, Eastern Borderlands were occupied by Germans as well, namely Reichskommissariat Ostland and Reichskommissariat Ukraine. Each new administrative district had a different political and economic situation, as well as the occupant's individual legislation. However, I shall not analyze those differences, as they fall outside the scope of my interests. Albeit it is important to note, that the socio-economic structure of Second Polish Republic remained highly diverse, even after being changed by the occupant's ordinances. Civilization and demographic differences between province in its broad meaning (villages and small towns) and big cities seem the most far-reaching. There was an enormous difference between Warsaw and a small town in the Subcarpathia region or a khutor in the Borderlands. It applied to all aspects of life: economic conditions, severity of the occupation regime, characteristics of a community. Big cities were islands of relative wealth and higher civilization standards in the landscape of Polish province.

Czesław Miłosz wrote the following on Polish province: "Poland, meaning its villages and small towns, there was nothing cheerful about it [...]. Crooked cabbies, women with their bare feet flattened out by the firmness of the paths, melancholic hens on piles of manure, a kind of numbness of existence, not life [...]. The impression of poverty (I do not care about statistics here, but say as it was, more or less) was intensifying when getting closer to Warsaw, and even a visitor from destitute Vilnius Region would become gloom on Masovian Plain"150. We know, however, that the cities were internally diversified as well; impoverished neighborhoods, which we would now even call slums, stretched next to villas, palaces, and elegant streets contrasting with them.

149 P. Weiss, Ziemia i chmury [Life and Clouds], Sejny 2002, pp. 24-25.

150 C. Miłosz, Zaczynajac od moich ulic [Starting with My Streets], Cracow 2006, p. 259. 
Great movement of people was characteristic for living under occupation. It included migrations, displacements, transports, fleeing, but also trade, business and conspiracy ${ }^{151}$. Masses of people would travel cross country due to ordinances of the occupier, because of their homes being destroyed in the course of warfare, or for other reasons. Krystyna Kersten in an essay with a characteristic title Ludzie na drogach [People on Roads] estimated that the number of "people brutally expelled from the scope of their existence" amounted to six million ${ }^{152}$. Piotr Łukasiewicz wrote: "In September of 1939 multitude of people was heading east, fleeing from the German army. The first years of occupation generated a mass refugee problem and mass displacement from the territories annexed to the Reich to the territories of General Government. After the Warsaw Uprising, the people driven out from the capital were looking for refuge in other cities"153. The same happened to Jews looking for shelter, who would often travel many kilometers to find a hideout far away from their home towns, in a completely different place. It was often decided by fate and not by conscious choice.

Hiding places in cities, villages and forests differed from one another significantly, which was connected both with the physical and social environment, and with political conditions. The level of isolation of Jews, going through their tragedy, from Poles, was relevant as well. It relates to all the events affecting Jews, hence also the phenomenon of hiding oneself. Feliks Tych, when writing about the image of the Shoah in Polish journals, stressed: "In general there is one clear distinction in the memoirs - the perception of the Shoah in the eyes of the witnesses is different in big cities and in the small towns and villages, where the Shoah would usually happen before the eyes of local Polish people and it was impossible not to notice. In that second case the approach to Jews varies, but there is no silence about the Shoah. In big cities, on the other hand, where the Jews were rushed from the ghettos straight to the death transports, a person who would not ask questions about the fate of the Jews, would not have to be confronted with this problem on daily bases. The division meant more than just a physical wall"154.

151 See C. Madajczyk, Polityka III Rzeszy w okupowanej Polsce [Policy of Third Reich in Occupied Poland], Warsaw 1970.

152 K. Kersten, Ludzie na drogach. O przesiedleniach ludności w Polsce 1939-1948 [People on Roads. On Displacements in Poland 1939-1945], "Res Publica" 1987, No. 4.

153 P. Łukasiewicz, Funkcje domu w okresie okupacji niemieckiej [Functions of Home during German Occupation], "Kultura i Społeczeństwo" [Culture and Society] 1989, No. 33(2).

154 F. Tych, Długi cień Zagłady [Long Shadow of the Shoah], Warsaw 1999, p. 24. 
As the majority of aforementioned examples of hiding places came from urban areas, I shall now describe them in a fairly concise manner, only stressing their most important characteristics. I shall rather focus on rural areas and areas located outside the populated territories. They are not analyzed in much detail, despite there being plenty of source material on that type of a hiding place.

\section{Hiding places in cities}

Prewar Poland was not a highly urbanized country. Cities used to stand out in a landscape dominated by "fields and forests". Those very cities were the areas where the forced concentrations of Jews, i.e. ghettos, would be usually built. Before the creation of the ghettos, during their existence, and especially after their liquidation, the cities became the space where the people sentenced to death would look for shelter. Hiding places in ghettos, often in one's own home or in a bunker, which were created in fear of mass displacement, and about which I wrote above, were situated in the urban landscape. From the point of view of people leaving a ghetto or escaping during displacement, a city offered a multitude of potential hideouts, some more accessible than the others, the pros and cons of which were hard to calmly consider in a crisis. A choice of a hiding spot in a city outside the walls of a ghetto was in a way obvious for locals from the said city. Both on the territory of a ghetto and after escaping it, using their knowledge of topography, links with non-Jewish population, relationships and connections, they had higher chances of finding lodgings. Yet Jews used to be sent to cities they did not know as well: displaced during creation of a ghetto, looking for family or friends, escaping transports, or simply changing their location as a result of confluence of events. In such cases their situation was more difficult. Many believed that it would be easier to find a hideout in a big city. That is why many people would make their way e.g. to Warsaw. Those people were yet to find their bearings in the city's labyrinth with no foothold in its physical or social structure, and in the case of people relocated from rural areas - also with no experience of functioning in this other environment. Looking for a place and fixing it up, as well as all the "survival strategies" they undertook called for acquiring special knowledge in a city. That knowledge concerned know-how of getting about in a more complicated, multidimensional reality with different rules than the countryside.

Hiding places in urban areas divided into:

- hiding places in one's own home;

- hiding places in somebody else's home; also in a tenement, in a yard, in outbuildings; 
- hiding places in non-residential buildings (factory, church, shop, warehouse, etc.);

- hiding places in specially prepared bunkers;

- hiding places in city ruins, in a destroyed building.

It goes without saying that small and big cities had some common features, as far as topography is concerned. They differed, however, when it came to a level of urbanization and concentration of certain elements, such as number of streets and buildings, their appearance, heterogeneousness, size, presence of other elements of urban infrastructure. The differences were present also on the social, political and economic levels, making for various conditions for the Jews in hiding.

\section{Big cities}

Before the war, a fourth of Polish Jews (24.6\%) lived in one of the following big cities: Warsaw, Łódź, Lviv, Cracow or Vilnius ${ }^{155}$. In those cities, the Jews made up for more than $30 \%$ of citizens. During the war, a dozen or so of big Polish cities (including Warsaw, Łódź, Lublin, Białystok, Cracow, Lviv, Grodno, Vilnius) provided shelter for many thousands of Jews. The situation in cities was quite challenging, mostly due to the existence of ghettos and constant presence of numerous Germans. On the other hand - the specificity of big cities means some anonymity and enormous space, and thus - almost endless hiding opportunities. Anonymity decreasing a risk of exposure was, however, limiting the number of friends and relatives who could help.

As there are studies on the Shoah in big Polish cities ${ }^{156}$ and the highest number of testimonies covers those areas as well, I believe this issue to be relatively well described and present in scientific discourse. Similar, with due proportion, is the case of the narrow scope of the subject of Jewish hiding places. The only studies addressing solely this subject published to date are connected with Warsaw ${ }^{157}$. I too, when describing the aforementioned types of hiding places, take from the collection of "urban" testimonies by the handful. Thus, in order not to repeat the already mentioned thoughts, I allocate comparatively little space for this type of hiding places, believing that characteristic features thereof have already been

155 Historia i kultura Żydów polskich. Słownik [History and culture of Polish Jews. Dictionary], eds. A. Cała, H. Węgrzynek, G. Zalewska, Warsaw 2000.

156 See e.g. K. Zimmerer, Zamordowany... [Murdered...]; A. Biberstein, Zagłada... [Holocaust]; B. Engelking, J. Leociak, Getto warszawskie... [Warsaw Ghetto].

157 Cf. G.P. Paulsson, Secret City...; Utajone miasto...; J. Nalewajko-Kulikov, Strategie przetrwania... [Strategies of...]. 
properly specified above. I shall only mention that the types of hideouts occurring in the cities are essentially all of the hiding places I have listed, of course except of those characteristic for wooded areas.

\section{Small and medium-sized cities}

Small and medium-sized cities (shtetlekh), excluded from the area of so-called provinces were a natural living environment for a great number of Jews before the war. Detailed information on demography in the pre-war Poland can be found in HIstoria i kultura Żydów polskich [History and Culture of Polish Jews] dictionary ${ }^{158}$. Jewish population lived mainly in cities and towns of eastern and central Voivodships; a total of $76.4 \%$ of Jews lived in cities (while for the rest of the citizens of Poland the ratio of populating cities and towns was exactly opposite). The highest percentage of Jews in population of cities was noted in eastern Voivodships (the Polesie Voivodship - $49.2 \%$, the Volhynian Voivodship $49.1 \%$, the Lublin Voivodship - $42.9 \%$, the Nowogródek Voivodship - $42.6 \%$, the Białystok Voivodship - $38.7 \%$, the Stanisławów Voivodship - $34.8 \%$, the Tarnopol Voivodship - $34.7 \%$ ) and the Warsaw Voivodship (over $34 \%$ as well).

The Jews usually used to represent several tens of per cent of the population (in many cities and towns the percentage of Jews would exceed half of the overall number of citizens, e.g. in Jędrzejów - 73.1 \%, in Pińsk - 63.4 \%, in Węgrów 60.45 , Kobryn $-55.6 \%$ ), hence the changes induced by occupation repressions sanctioned against them were exceptionally substantial and completely changed the shape of the social space.

Sometimes, in small towns there were no clearly separated ghettos, but e.g. designated houses or streets. Instead of a wall there could have been a barbedwire or other fence. Not every ghetto was locked down right away. Sometimes the suburbs were earmarked for a ghetto and the Jews were removed from the city centers. In many towns, there were never any ghettos and the Jews living there were relocated to ghettos in other towns. Looking at the small-town ghettos, one has to especially remember about the small size and claustrophobic space, where it was not easy to find a hiding place. As Eva Hoffman writes in a book on the town of Brańsk: "I'm trying to imagine it now: a scrap of town, no bigger than a village, densely built-up with short homes, now cluttered with smaller barracks, which were erected after relocating the old residents to the other ghetto. Everything is so small, so much displayed to the public, so transparent. How could

158 Historia i kultura Żydów polskich... [History and Culture of Polish Jews...]. 
anyone hope to hide, escape the surveillance by the guards, who would turn on the searchlights in the evenings to track every move of the inhabitants of this miserable cluster of people?" 159 On the limited, tiny space, in the face of lack of buildings securing a possible shelter, and in a big city (tenements, warehouses, factories etc.), people would simply escape the ghettos during displacements and try to look for a hideout outside the city limits. Icchak Aron wrote the following on liquidation action of the town of Miory (the Vilnius Voivodship): “Tuesday, $2^{\text {nd }}$ June 1942. A whole town was slaughtered like sheep in a morbid carnage. Only few of us survived. I have escaped with the others (mostly young people) from the city square. We were shot at. Many died trying to get away, only few managed to get out alive. I was lying in butcher Icchak's house till the night came. Then I left the town"160. The types of hiding places occurring in small towns include almost all the hideouts mentioned above, except of those characteristic for wooded areas.

In many respects, shtetlekh were more similar to the surrounding villages than to big cities. This applies to social phenomena as well. Eva Hoffman put it this way: "Shtetl was an area where the Polish-Jewish relations would get extreme. In villages and small towns both Jews and Poles were the most endangered and vulnerable, and the political conflicts would have the most heated character there"161.

\section{Hiding places in the countryside}

While the documents from the Warsaw Ghetto are considered to be canonical, there are many texts describing the fate of Jews who tried to find salvation in the countryside. In many respects, this experience was different from the trials of people hiding e.g. in Warsaw; those differences were especially noticeable for those Jews, who previously spent their lives in a city and did not know the countryside. They were just getting to know it after the fate put them there while they were searching for a hiding place.

Jacek Leociak stated: "Countryside's topography lacks elements of urban scenery. Cobblestones, pavements, tenements with rows of windows and balconies locking a perspective of the street, everything is traded for the open space of fields and forests intersected by ribbon-like roads" ${ }^{\prime 62}$. It is important to stress that

159 E. Hoffman, Sztetl [Shtetl], Warsaw 2001, p. 197.

160 I. Aron, Relacja [Testimony], in: Życie i zagłada... [Life and Holocaust...], p. 509.

161 E. Hoffman, Sztetl... [Shtetl], p. 19.

162 J. Leociak, Wizerunek Polaków w zapisach Żydów z dystryktu warszawskiego [Image of Poles in Notes of Jews from Warsaw District], in: Prowincja noc... [Province of...], p. 395. 
the fundamental issues of hideouts in the countryside and in wooded areas (and outside the limits of a shtetl) were the topographical conditions: terrain, density of forestation and population of a given areas. In realizing the importance of those elements on effectiveness of a hiding place, a journalist-like point of view of Anna Bikont, who watched the surrounding fields with the eyes of a person looking for shelter on her way to Jedwabne (the area has not changed greatly since the times of the occupation), can be helpful: "Kilometers of open space, scarce tufts of trees here and there - flat Mazovian landscape makes me realize how slim the chance to hide from the attackers must have been. Admittedly, now it's winter and then [when the Jews were massacred in Jedwabne in 1941] it was July, the crops have not been harvested yet"163.

So, on the one hand there were less people, meaning less threats. But on the other hand, fewer buildings meant that the people hiding could rely only on themselves and on the nature, sometimes inhospitable. When considering the pros and cons of hiding places in the countryside, one has to have in mind the considerable differences between the urban and rural environments in the 40s. There were no ghettos in the countryside, representatives of occupation authorities were virtually absent there, which allowed for greater freedom ${ }^{164}$. The rigor would get stricter in certain moments, e.g. when the frontline advanced. The representatives of local authorities, in turn, the soltys and the blue policeman played an important role.

The attitude of a village's locals toward the Jews was another issue ${ }^{165}$. Zofia Dulman wrote: "People would scare the children with stories about Jews, just like they used to do with Gypsies. I once heard Ukrainians talking in some shack. They said that it is dangerous to walk into the woods, as the Jews are hiding in bushes and jump out at the sight of a passers-by to bite off their noses"166. Cases of not only reluctance, but also denunciation and even aggravated assaults against Jews, destroying their hideouts or taking their lives were not uncommon in Polish

163 A. Bikont, Myz Jedwabnego [Us from Jedwabne], Warsaw 2004, p. 26.

164 C. Madajczyk, Polityka... [Policy...]; A. Skibińska, J. Petelewicz, Udział Polaków w zbrodniach na Żydach na prowincji regionu świętokrzyskiego [Participation of Poles in Crimes Against Jews in Countryside of Świętokrzyski District], "Zagłada Żydów" 2005, No. 1.

165 See A. Cała, Wizerunek Żyda w polskiej kulturze ludowej [Image of a Jew in Polish Folk Culture], Warsaw 2005.

166 Z. Dulman, Relacja... [Testimony], p. 583. 
villages ${ }^{167}$. Ringelblum has diagnosed the situation of Jews in Polish countryside already during the war. His perspective was very pessimistic, yet probably quite realistic: "The attitude of the rural population towards Jews depended on the prewar sentiments in a given area towards the Jewish population. Where there was a deep-seated Jew-consuming anti-Semitism, the attitude of the rural population towards the Jews who were escaping the Hitler's knife was not proper. In such neighborhoods, the rural population would catch the Jewish escapees from ghettos and turn them in to the Germans for thirty pieces of silver. 'Village guards' who were supposed to fight the partisans played a tragic role, as they specialized in hunting Jews who escaped during displacement actions"168. Bańkowska wrote about the same as well: "A presence of even a small group of people in the same place in a forest for a long period of time could not go unnoticed by the locals, even if the Jews would get supplies from just one farmer. To be sure, this knowledge could stay unused: in the accounts, there are assertions about solidarity of silence of all the local inhabitants about the Jews hiding. However, using this knowledge for profit, to serve German authorities, and to settle private scores or to unload one's own aggression is a fact present in many testimonies"169.

One can hypothesize (as Bańkowska did) that in the light of simpler living conditions, less complicated social structure and general living conditions in the countryside, szmalcownictwo and blackmail were a fairly uncommon threat. Crimes, if they occurred, were "simpler" and definitive. Skibińska and Petlewicz enumerate: "1) robbery, 2) denunciation, 3) personally participating in hunting the hiding Jews, 4) personally participating in murder, 5) acts of physical and psychological abuse of the apprehended people, 6) denunciation of Poles aiding Jews" ${ }^{\prime 170}$. Barbara Engelking ${ }^{171}$ and Jan Grabowski ${ }^{172}$, when writing about the fate of the Jews hiding in the countryside, were also greatly stressing presenting the

167 A. Skibińska, J. Petelewicz, Udział Polaków... [Participation of Poles]; A. Żbikowski, U genezy Jedwabnego... [The Genesis of Jedwabne...].

168 E. Ringelblum, Stosunki polsko-żydowskie w czasie drugiej wojny światowej. Uwagi $i$ spostrzeżenia [Polish-Jewish Relations during the Second World War. Notes and Observations], Warsaw 1988, p. 15.

169 A. Bańkowska, Las jako miejsce przetrwania... [Forest as a Place of Surviving...], p. 70.

170 A. Skibińska, J. Petelewicz, Udział Polaków... [Participation of Poles...].

171 B. Engelking, Jest taki piękny słoneczny dzień... Losy Żydów szukających ratunku na wsi polskiej 1942-1945 [Such a Beautiful Sunny Day... - Jews Seeking Refuge in the Polish Countryside, 1942-1945], Warsaw 2011.

172 J. Grabowski, Judenjagd. Polowanie na Żydów 1942-1945. Studium dziejów pewnego powiatu [Hunt for the Jews: Betrayal and Murder in German-occupied Poland], Warsaw 2011. 
documented acts of aggression, denunciation and murder, for which the rural (or small-town) environment was a setting completely different to the one of the space of a big city.

The issue is presented in the source materials in wide varieties. Insofar as the author of the testimony is considered, his or her assessment of the situation always depended on personal experiences. For some, who miraculously survived from actions in their home city or town, the countryside could have meant the salvation. For others - it was a place where it was impossible to hide. The two following quotes show how fragile and ambiguous everything was. Chaim Icchak Wohlegelernter, a resident of Działoszyce (the Kielce Voivodship), had positive things to say about the people in the village, with a reservation of a corrupting role of the materialistic agent - the farmers wanted to seize the things that belonged to Jews. "It was easier to save oneself in the countryside. A simple farmer had no hatred towards us - on contrary, he was always eager to contact a Jew, believed him in every respect. If a Jaw had not entrusted him with his possessions for safekeeping, there was no reason to harm that Jew or do something bad to him. The farmers sympathized with our sorrows and misery. They showed it by treating us to bread and water. They were admittedly afraid to welcome us to their homes, as announcements were posted in every village saying that a person who opens a home to a Jew or gives one a piece of bread will pay with his or her life. In spite of this, when the things calmed down a bit, they let us sleep in barns and even received women and children at homes"173.

Florian Majewski (Mosze Aron Lajbcygier) saw the issue of hiding in the countryside differently. A friend hid him in Siucice, a village near Żarnów. While still hiding, he was supposed to work as a carpenter and his friend was to organize tools for him "- Look what I have got - he said. He seemed upset. - Whenever you ask for something, they immediately want to know what for, for whom and why. It seems like they have sniffed you out. I knew very well that the people in the village can sniff out anything. One look at the clouds will tell you what the weather is going to be tomorrow. The smallest track in the moss will give away what kind of animal went through there. And when a carpenter's borrowing tools, it means he has a worker at home"174.

When considering a threat of an exposure of a hiding place and a risk connected thereof, a shortened distance between the hiding person and the locals, which was typical for villages, is important. In a city, especially a big one,

173 AJHI, 302/46, Testimony of Chaim Icchak Wohlegelernter.

174 F. Majewski, Pustelnik [Hermit], Warsaw 2002, p. 41. 
non-Jewish residents could more easily keep a neutral detachment from the hiding Jews, with whom they could have even not had physical contact in the vast and complicated urban space. In a microcosm of a village such an avoidance of direct interactions was a lot harder, if not impossible. For one thing, it was caused by the confined and scarce space, where everybody was closer together. The second thing was the strictly limited, tight circle of social interactions between few neighbors who knew each other very well and where everybody was in some way dependent on everybody else. Thirdly, there was a closed and tight circuit of information, where no news could go undetected. The fourth factor was the simplicity and monotony of rural life, where any event in any way diverging from the routine was first arousing comments, and later reactions.

A common pattern of hiding in the countryside was living "partially on the surface", but with no fake papers. Jews were not constantly sitting in hiding, but were helping around the farm and were trying to go unnoticed by the neighbors and the authorities. They were therefore falling under a stereotype of a "travelling shepherd" or other people who turn up in a village, and so they inconspicuously inserted themselves into the rural community. They often managed to survive like that for many months. The uncertainty of the situation made for the status of such a person to be fluent, it could to go in either direction. Hence going "underground" and "back to the surface" was possible without any additional measures. Dwojra Frymet, who was hiding in a borderland village, took over a farm of her employers, when they were in danger: "One Polish lady took me in. [...] Since my good man killed some Ukrainians with a few other people from that village, they had to run. I stayed on the farm by myself. I would feed the cow, milk it, make cheese and butter and trade it for sugar. Farmers from the village were envious and mad at me"175.

Poverty shared with the farmers was the basic experience of the Jews hiding in Polish countryside. Material conditions, but also staggering civilization underdevelopment of Polish villages made up for this poverty. Czesław Miłosz wrote about Polish villages that "not only the foreigners got an impression of a strangely backward world, actually reduced to an animalistic level"176. The direct accounts by the writer are confirmed by works of sociologists interested in poverty. Elżbieta Tarkowska wrote in a text on past and present poverty in Poland: "Poverty and misery to a large extent affected the rural population in

175 D. Frymet, Relacja [Testimony], in: Życie i zagłada... [Life and Holocaust...], p. 609.

176 C. Miłosz, Wyprawa w dwudziestolecie [Journey into Two Decades], Cracow 1999, p. 342 . 
the interwar period as well. The peak of poverty occurred in two periods: immediately after the wartime destructions of the First World War and during the Great Depression"177. The author presents estimates (after Janusz Żarnowski), according to which in the most economically trying interwar period there were four million poor people living in villages, a million of whom lived in extreme poverty. The Second World War did not eliminate rural poverty. Despite various new economical phenomena that arrived along with the occupation (in the first place we have to enumerate the illegal food market, thanks to which the villages - food suppliers for the hungry cities - would get an influx of money and industrial products $\left.{ }^{178}\right)$, the countryside remained extremely poor.

For some (especially those better-off before the war) escapees from cities the life in the countryside - backwardness in respect to hygiene, lack of basic appliances known from urban homes, would even cause culture and civilization shock. The previously quoted Rut Leisner was hiding with her family from spring of 1943 to February 1944 in Osinówka village at farmers Sylweter and Zuzanna's place. "Their cottage was small and primitive, even for that area. It consisted of one chamber with earthen floor instead of a normal one, with thatched roof over pig pen and a little barn - everything under one roof. Inside there was a flat-topped brick furnace with a place to sleep. The bricks were made by hand form clay and stone and the furnace was used as a kind of partition separating the room where they wood cook and do laundry, and where they placed a bed behind a discolored curtain, a table made out of untreated wood, benches, a few simplest pots, wooden plates and cutlery, basically - all their worldly possessions. Sylwester dug a pit under the furnace, not bigger than a small table, with a big entrance on the back, so that an adult person could squeeze through. The entrance was later covered by a board and a bunch of garbage was thrown on top of it with old clothes and whatever was lying around, and on top of all that a bed was placed as an ultimate disguise. The four of us would squeeze inside one by one and sit: two at the back and two at the front, with our legs huddled between one another's, motionless and in complete darkness. The shelter could not have been dug deeper, as it would take in water. We would sit like this whole days, in

177 E. Tarkowska, O dawnej i obecnej biedzie w Polsce [On Former and Present Poverty in Poland], in: Zrozumieć biednego [To Understand the Poor], ed. E. Tarkowska, Warsaw 2000, p. 52.

178 C. Madajczyk, Polityka... [Policy...]. 
dampness and darkness, going out only at nights. We were allowed to sleep atop of the furnace only when it was deemed safe" ${ }^{\prime 79}$.

Sometimes, with knowledge and consent from the good man, a shelter was built away from the house. The conditions in those shelters were extremely difficult as well. Mendel Cienki, who was hiding in a village near Międzyrzec, wrote: "Some of the Jews, the ones who had the money, built bunkers at the villager's places. It was believed that they won't have to stay there for long, as the Russians would come soon (it was, of course, in the winter of 1942-1943). Mendel was in a bunker in a field. In a barn with a wooden floor a hole was dug. It was only a square meter big and there were twenty people inside, stack on top of each other. It was dreadfully stuffy, giant flees were slouching around, there was no water, as people were afraid to go out to get it, as the villagers could see them"180.

There were also cases when the Jews were trying to act on their own and seek shelter exploiting the hosts' obliviousness. Lipa Wołkowicz, who was hiding near Żyrardów, says: "While being alone and not being able to continue working as a tailor, I was doing everything to get by in this twisted life, not always with honest means. Many times, have I stole from a pig, a dog, a goat who were given food in a trough, some mashed potatoes. Many times, have I snuck into homes of the farmers I knew or didn't know to steal bread, potatoes etc. Many knew that the milk gone from the pitcher and emptied udders of their cows were my doing. I would not incur any consequences of that. [...] This is how I was hiding with the farmers with them knowing and not knowing, with their consent and without it, in forests, fields, cereal, in pits, outhouses, haystacks, straw, ruins. Many times,

179 R. Leisner, A jednak... [The Miracle...], pp. 216-217. The problem of relatively wealthy hiding townspeople clashing into terrifying lack of resources (mainly cash and manufactured articles) of villagers when "under one roof" is described in economic categories by Barbara Engelking in Dolary skupuje, koty przechowuje [I buy dollars and keep cats] (Barbara Engelking interwieved by Anna Bikont), "Gazeta Wyborcza Swiąteczna" 2008, No. 40: "Clash of social classes is another big subject, whch was well presented e.g. in journal of Fela Fischbein from Krosno. She was from the city, from upper middle class. [...] In the countryside she saw horrid poverty, lack of things and money - rural economy was non-monetary. Everything was appealing for the people there: old Jewish rugs, broken furniture. The countryside really needed the money - and the hiding Jews were introducing open currency to circulation". This event could have had various social consequences. A sort of market for hiding Jews was created, and not only in the countryside. The demand was shaping a steady increase of prices. A chance to welcome well-paying "tenant" under one's roof could tempt people to various immoral acts.

180 AJHI, 301/1437, Testimony of Rywka Wajnberg and Mendel Cienki. 
have I escaped death, who was reaching for my neck, until $6^{\text {th }}$ January $1945^{\prime \prime 181}$. Similar was the case of the above-mentioned Mendel Cienki, who was hiding at a farmer's place, calling it "at the uncle's" ("uncle took Mendel to his place, to a barn”, meaning he's invited him into a hiding place). In Mendel's story the sentence: "The farmer had no idea" 182 comes back like a chorus.

Małgorzata Melchior cites numerous examples of the accounts of the Jews hiding in the villages of Warsaw District, concluding that a strategy of living with the farmers and working for them at the same time is often repeated in the testimonies, but is not the only model. "Individual elements of the existence of the ghettos' escapees on 'the Aryan side' were interconnected. Finding some place to stay - a roof over one's head and food - could have been conditioned by having some means to live or connected with simultaneously doing some works or getting a job. Some would hide in the fields, in haystacks, in demolished buildings, in buildings located far away from human abodes, in mounds, on barges, cemeteries, but primarily in forests"183. I shall describe that path of looking for a shelter away from people later.

\section{No man's land}

The areas to which I refer as "no man's land" are a sort of a borderland: neither countryside nor city, a place seemingly better to hide in, because of it being free from an enormous amount of threats connected with close proximity of human abodes. In reality - a place in which it was extremely hard to settle. Hiding places in the areas I am calling "no man's land" were therefore relatively safe on the one hand, but on the other required an immense determination, knowledge, physical strength and skills to survive in inhospitable conditions with no conveniences of civilization and a limited access to outside help.

In this section, I shall describe the hiding places "in a forest", which benefited from the protection of wild nature, and the ones in "excluded places": camps, demolished ghettos, places of execution, in other words the places, where regular life had no access due to the occupant's regulations.

181 AJHI, 301/6792, Testimony of Lipa Wołkowicz.

182 AJHI, 301/1437, Testimony of Rywka Wajnberg and Mendel Cienki.

183 M. Melchior, Uciekinierzy z gett... [Escapees...], p. 346. 


\section{Woodland hiding places}

Aleksandra Bańkowska wrote two studies on the subject of Jewish hiding places in forests: an article on hiding near Boryslav ${ }^{184}$ and a monograph about the general issue of hiding on the territory of occupied Poland ${ }^{185}$. Małgorzata Melchior wrote about Jews from the countryside in Warsaw District hiding in forests as well ${ }^{186}$. The following findings derive from those very texts. Bańkowska drew attention to the specificity of the issue and wrote: "Woodland hiding places as a place of surviving the Shoah are one of the less studied threads of the history of the survivors. Sometimes it seems to me that this phenomenon was more common than it is commonly believed. This issue is marginalized in historiography, it is often presented in the context of Jewish guerilla"187. A theme of shorter or longer period of hiding in the woods is present in nearly all of the reports from Eastern Borderlands. It can be explained in the simplest way possible - the prewar (and wartime) Poland was a primarily forested country. Eastern territories had an especially small density of population; except for sparsely scattered district towns, there were mostly villages, which were also separated with stretches of woods. Looking for shelter there was the most natural instinct.

Family camps, which I have already wrote about, are one of the best described ways of hiding in a forest. However, this is certainly not the only model of a woodland hideout. When analyzing the testimonies of hiding people, I was able to distinguish the following types of hiding places in a forest:

- temporary - a single overnight stay in a forest,

- wandering without a permanent hiding place (I shall write more on the subject in an appropriate subchapter),

- dugouts - singular or clusters,

- hiding in woodland settlements.

In her work Bańkowska also gives an example of hiding in natural caves, high cereals or grass, in bushes, on islands, i.e. attempts to make use of the circumstances created by nature itself. Due to the provisional nature of such shelters they were usually used as short term hiding places.

The Jewish guerilla is an important issue. This phenomenon certainly should not be analyzed solely as a way of hiding and saving oneself, but to some extent

184 A. Bańkowska, Leśne kryjówki... [Woodland...].

185 Eadem, Las jako miejsce przetrwania... [Forest as a Place of Surviving...].

186 M. Melchior, Uciekinierzy z gett... [Escapees...].

187 A. Bańkowska, Leśne kryjówki... [Woodland...], p. 1. 
the camps of partisans were a form of physical hideout. The partisans - Jewish, Polish, Soviet or other - were in a specific situation. In fact, from the point of view of the occupant, they were outlawed, just like the Jews. Their place of residence had to remain a secret. However, due to them being armed, having received military training and being a part of a military structure, they felt more confident than the "civilian" hiding Jews. In a part of this chapter devoted to assisted hiding places, I have mentioned a specific form of hiding, i.e. the family camps. As they were situated in forests, I shall quote one testimony to give a gist of how such a camp fitted into the woodland surroundings. Josif Szwarc and Josif Kogan said: "On the $12^{\text {th }}$ May [1942] we came to the Bełski’s division, which was stationed near Nejman Works in Vselyub municipality, the Nowogródek County and Voivodship. Bełski's was a family division. When I asked Bełski, he said there were 700 people in the division, which later grew [to] 1200. Among this huge number of people there were 97 children. The whole thing was divided into family groupings, where women with children would stay. In the fighter's area, where there were weapons and they went to fight in diversion actions, they lived separately. We used to live in huts (palatkas) [from Russian word палатка, meaning tent - translator's note] made out of branches. When the winter came, somewhere around October, dugouts were dug, each of them 8 meters long, 5 meters wide and about one meter high. They could not dig out deeper ones, as the area was muddy. The dugouts were floored with boards on the inside and each of them had windows and one exit. They were well disguised with branches. The division had: cobblers, carpenters, tailors, a bathhouse, a disinfecting room, a dentist, a hospital chamber. A bit later, already in 1944, gravediggers, tinsmiths, blacksmiths, furriers, barbers, watchmakers, weapon-assembly specialists, a baker, and we even had a mill came to us. The mill was designed to work with horses, which were cutting and milling the cereal. You needed special stones for that and we had them. This way we were getting 300 [to] 400 kilograms of flour a day. The workshops were located in a separate dugout, which we called a cooperative. This cooperative dugout was long, had fitted windows as well and was perfectly cloaked. The workshops were producing items not only for our purposes, but for the surrounding divisions too. This division was in contact with all the partisans located in the nearby forests"188.

Residents of woodland hiding places often lived in a characteristic symbiosis with the people from the nearby villages. The villages were primarily a source of food - Bańkowska distinguishes three ways of obtaining it: purchase (often

188 AJHI, 301/505, Testimony of Josif Szwarc and Josif Kogan. 
barter), "begging or benefiting from selfless help" and theft - form farms, fields or orchards. The people in hiding used the help of farmers to build shelters. They were receiving or buying items vital for setting up those shelters from the farmers. Contacts with the villagers were also a way of getting information about the world outside the forest. In extreme situations, it was also possible to spend some time on a farm, to warm up, get a condition treated. However, local people were also the main threat - hiding people were afraid of robberies, denunciations and murders; using caution and intuition when coming into contact with a village, so as not to disturb the fragile balance allowing for survival, required major talent.

Hiding places in a forest, even those prepared very carefully, were characterized by simplicity and stringent conditions, to which one had to adapt in order to survive. It was the price of having more liberty. Zofia Dulman wrote: "I have spent two months in a hideout among Jews. [...] We used to sleep in a cramped pit and cook nearby in a pot hanging on a wire over a fire. At nights, the men would go to deserted Polish shacks to get food and water. I used to wash the child in basins, in a liter of water. I used to strip her naked in the forest and she didn't even catch a cold, even though it was October. We could relax for a while. The Germans didn't know about us yet and the Ukrainians were busy killing Poles, so they have apparently not been paying attention to the remaining Jews"189. Much depended on the seasons and weather. Rain, snow or freezing temperatures were a deadly thereat to the people hiding in the woods. Winter was the worst. Bańkowska sums up the struggle of the residents of woodland hiding places against winter conditions: "Winter was the hardest for the residents of forests. Winter, thanks to the snowfall, would cut the hideout off from the world, which was good for safety purposes, but also bad, as it was making any contact difficult. Winter limited activities, forced people to sit in a dugout all the time, from one hand because of the frosts, and on the other - because of leaving tracks in the snow. Each time somebody would go out, they would leave footprints and therefore make discovery of the bunker possible. To limit going out, the people would frantically drag provisions of food and firewood to a hideout in the fall. It would limit the need to go out, but not eliminate it: it was necessary to take out the night soil, ventilate the bunker and shovel snow off the roof, so it would not collapse and the snow would not block vents and exits. Also, despite wishing to do so, it was not always possible to gather enough food. Therefore, people would come up with various ways of masking tracks. They would sweep the ground with a branch, walk on stilts, jump from one shrub to another, shake the snow

189 Z. Dulman, Relacja... [Testimony...], pp. 581-582. 
off the trees, make fake tracks, and go out only during a blizzard. Moreover - the soil warmed up inside the bunker would thaw and the walls could start melting down. Losing a bunker during a winter would practically make it impossible to build another one before spring, as the soil was frozen. Getting water was a problem as well: Florian Majewski used to melt snow and filter it with a cloth. Inability to move about, the necessity to sit or lie down in one position was very burdensome. The dampness of a dugout had an adverse effect on health: people would develop skin and eye conditions and limb paresis"190.

Hiding place in a forest demanded the people in hiding to have a lot of physical strength, wit, durability and resilience against Spartan conditions. Only healthy and resourceful people ready to face the many challenges of living in a forest were able to survive there for a prolonged time. Those mainly included assisted hiding places "at a distance" connected with more self-reliance, but, in turn, allowing for some physical liberty, contact with nature, fresh air. They are extremely different from e.g. urban hideouts: traps of double walls, stuffy bunkers, cramped rooms behind closets. Forest, with all their austerity and poverty, provided the hiding people with some fresh air, clean water, peace and quiet. Other people infiltrating the woodland world were the biggest threat. The biggest hardship was enduring the extreme poverty in cold burrows, bringing to mind a completely primitive level of civilization.

\section{Concentration camps, labor camps, death camps, places of execution and other "excluded areas"}

The areas I am referring to as excluded areas usually include extreme places, with their own special sets of rules. They are not uniform, but they are connected by being excluded from the normal social order, a unique construct of space, particular intensification of violence, omnipresence of death and extremely severe conditions of those hanging on to life. Such places mainly include German camps. I will not go into detail on the specificity of camps, as there are many studies on the subject ${ }^{191}$. I shall only stress the enormous difficulties in organizing

190 A. Bańkowska, Las jako miejsce przetrwania... [Forest as a Place of Surviving...], pp. 56-57.

191 See J. Marszałek, Majdanek, obóz koncentracyjny w Lublinie [Majdanek, Concentration Camp in Lublin], Warsaw 1987; Obozy pracyw Generalnym Gubernatorstwie w latach 1939-1945 [Labor Camps in General Government 1939-1945], Lublin 1998; A. Pawełczyńska, Wartości a przemoc. Zarys socjologicznej problematyki Oświęcimia [Values and Violence. Overview of Sociological Issues of Auschwitz], Warsaw 2004; 
hiding places in camps - when it comes to the conditions and chances of getting outside help.

Various situations could have led to looking for a hideout in a camp. I will only describe searching for a hiding place as a part of an escape plan. A hideout was necessary to peacefully wait until the time was right to escape. It would also save an escapee in case of a pursuit. Space of the camps was usually organized and strictly devoted to the tasks of a given facility and was not providing as many opportunities for finding a hiding place as the space of a city or a forest. The last chance to undertake a relatively successful attempt to escape was the moment of being transported to a camp. The number of such escapes grew as information about the camps spread. It was usually harder to break out from a camp itself and there were less places fit for a temporary hideout. Michał Maranda cites Yitzhak Arad who mentions two examples of breakouts from the Bełżec camp: "The first known case was an escape of two women, Mina Astman and Malka Talenfeld, who arrived in March 1942 on a transport from Zhovkva: 'taking advantage of the chaos, ruckus and inexperience of the Germans (it was one of the first transports arriving to Bełżec), Astman and Talenfeld jumped into a nearby dig and stayed there until it got dark. They have escaped the camp under the cover of darkness and got back home after a few days. The second case was an escape of dentist Buchner, who came on a transport from Cracow in the beginning of October 1942. He managed to hide in a latrine, where he stayed for a few days in a pit with excrements. Eventually he was able to escape the camp one night and go back to Cracow"192.

The space and structure of labor camps, densely spread across the territory of occupied Poland, were probably providing more opportunities. The camps were not as isolated from human abodes as the death camps were. Often the districts of towns with factory compounds were earmarked to become such camps etc. The strictness of the regime in those camps was less severe as well. Tamara Diamant used to live in Boryslav, and after the ghetto was liquidated, she was sent to the local labor camp (which she refers to as "the barracks" in her text). In 1943, camp authorities gave an order to evacuate to the Płaszów camp. It was tragic news for the prisoners. However, it turned out that the drivers were turning a blind eye to escapes from the camp and they did not want to obey the order to move as well - they had hiding places prepared for such an occasion. "People

R. Kuwałek, Obóz zagłady w Bełżcu [Bełżec Death Camp], Lublin-Bełżec 2005; M. Maranda, Nazistowskie obozy zagłady. Opis i próba analizy zjawiska [Nazi Death Camps. Description and Analysis Attempt of the Phenomenon], Warsaw 2002.

192 M. Maranda, Nazistowskie obozy... [Nazi camps...], p. 101. 
were escaping the barracks, there was less of them every day. There came a moment when the head of the barracks, Flaks, wanted to breakout too. Wishing to walk away with a clear conscience, he's decided to give one of the hideouts he prepared to the orphans. I was one of them. There were eight of us. They have told us to pack our things. [...] The road was horrible. [...] We go down through a small, half a meter big square. I was the last one in. It was dark inside and I couldn't see anything. We were placed on two bunks. The boards were wet and I have started flipping them over, but it didn't help a thing, as they were soaked. We fell asleep curled up on hard and wet boards"193. The Germans found that hideout, however, and sent the children back to "the barracks". When the transport day came, Tamara hid with the others: "We went out to the corridor. People were standing there, not knowing what to do, not thinking straight. Suddenly everybody started pushing into one room. I have pushed through as well, pulling Rutka by the arm. There was a hideout in a furnace. Over 30 of us went there into a narrow hole. We held our breath. Some German kept coming into the flat and yelling - Raus! - but he didn't see the hole. We have suffered like that for over 5 hours. Suddenly Szenbach brakes down the boards and flashes light into our eyes. He's hitting us with a rubber cat on the head, back and chases us out to the yard. [...] They kept coming up with new people. They have pulled two of them from a latrine, three from feather duvets, they looked terribly, feathers were flying all around the yard"194. Luckily, Tamara was able to get separated from the column going to a train and escape.

The report of Maks Resler, who was in a camp in Rozwadów near the end of the war, is completely different, but also incredible. He was planning to escape with his friends during Soviet air strikes in 1944. The camp was guarded by Germans and Ukrainians. "Because of the gunfight I was unable to get out of the factory site surrounded by the wire. The camp was in the middle of a factory area. [...] Seeing that I'm trapped, I run to an old iron scrap yard and hid there. [...] They were looking for me for half a day in those iron scraps and couldn't find me. One Nazi who was searching not far away from me got killed, when I hit him with a piece of iron. The rest of them started looking for him as well, but couldn't find him, I have covered him with iron. 8 days I was lying there hidden, with no food, no water, no air. I couldn't go out of there, as there were Germans on guard day and night. I was certain that I would not make it out of there, that I was going

193 T. Diamant, Relacja [Testimony], in: Życie i zagłada... [Life and Holocaust], pp. 294-295.

194 Ibid., p. 295. 
to die. I was trying to note my feelings and experiences in very faint light. First of all, to shoo away the boredom, impatience and nervousness. Secondly to preserve the memory, provided that somebody finds it (I had my journal with me). There were thousands of tons of iron there. It turns out that the dogs couldn't find me either. Perhaps the iron covers the tracks. I was covered with a car body. I had a knife on me and a handy piece of iron. I was ready to kill every Nazi who'd want to kill me at all times" ${ }^{195}$.

I classify the ghettos as excluded areas as well - especially the Warsaw Ghetto during the uprising of 1943 and after it was silenced. On the one hand, it is a district of a big city, with partially preserved urban tissue, but it is at the same time a territory engulfed by war, ruled by laws separate to those of the rest of the town, closed off for the outside visitors. After the collapse of the Warsaw Ghetto Uprising, it was impossible to find traces of normal life there. The district was ultimately cut off from the city. Thereby the people hiding in there obtained some room to maneuver; the deserted city was like a giant granary, a treasury of things. "Each deserted house was full of scattered clothes. We would change overly frequently" ${ }^{196}$. On the other hand, it was an enormous cemetery, where one would constantly stumble upon bodies of people who died or were killed, a cursed and frightening area.

Last but not least, a few words on hideouts in places of execution, made using the bodies of people killed as a cover from the hostile eyes. In the book entitled Tekst wobec zagłady [Text regarding the Shoah] Jacek Leociak mentions a recurring motif of corpses in accounts from the Warsaw Ghetto. There are texts regarding dead bodies, which could give a temporary shelter to other, still alive bodies.

This is probably the most shocking and ultimate form of shelter. "A stack of bodies where the dead and alive are mixed and piling up seems to only be a creation of a refined or even perverse imagination. Nonetheless, this was a completely real picture, and, for a certain period of 'final solution' it was even a usual one. Scenes of throwing live people into death pits, scenes of burying people alive in mass graves or finally scenes of the ones who survived the execution escaping from a heap of corpses, have been often confirmed in the texts of the survivors. It all seems like the non- crossable line between the life and death has been lifted in the world where the authors of the texts operate and where the events they describe take place. The reality available for everyday experience begins to take an

195 AŻIH, 301/36, Testimony of Maks Resler.

196 L. Silverstein, Tak właśnie było [That's What Happened], Warsaw 2002, p. 190. 
eschatological character" ${ }^{197}$. Among others, the author cites a testimony of Leon Najberg, who, during the Warsaw Ghetto Uprising, talked with a girl pinned down by bodies during an execution of residents of a bunker at 38 Świętojerska Street. Henryk Bryskier, another resident of the Warsaw Ghetto, survived an execution of management of Brauer's shop at Nalewki Street the same way. The girl from Najberg's text, Irka, was pinned under a corpse of her own mother and was conscious the whole time: "I held my breath and kept quiet"198. Bryskier's body was visible - he did not hide under the corpses, he fainted. Motionless, splattered with blood and brain of the murdered neighbor, he resembled the dead bodies. "The heroes of those [...] stories were executed, but [...] took refuge among the corpses and found salvation there. They have all shared an experience of crossing the line between life and death. They have in a way walked a mythological route to the land of the dead and returned to earth from the underworld"199.

The events described above took place in a city - Warsaw, in a Jewish district consumed by the uprising. However, I cite only parts of them, the ones talking about hiding places in the excluded areas, as similar events were occurring in places of mass executions as well: in suburban groves, forests, camps. One can conclude that a city street where a pile of bodies is a normal sight, becomes an excluded area, similar to the one in the space of an extermination camp. Here is an account of Jechudit Trojak, a girl from Vilnius, who survived the Ponary massacre on the $10^{\text {th }}$ September 1942: "When we got out of the truck, they took us to a forest over dunes and left us there. We have been hearing gunshots all day. At 5.00 in the evening they have selected and took ten of us and made us walk through the forest for a few minutes. They have blindfolded us and made us stand on the edge of the pits... I have moved the handkerchief so that I could see everything. There were many corpses in the pit. A layer on a layer. The Lithuanians told us to kneel down. And started shooting right away. I felt some pain in my arm and fainted. When I came to I saw that I was lying next to my shot mother. The pit was full of corpses. I have started crying from the pain. I have suddenly noticed that somebody was holding my hand and I got really scared. But I have heard a voice of some woman who whispered to me to stop crying, because they could come back and finish us off. The woman told me that we would escape together when it would get dark. So I was lying there quietly. I stayed like that for a few hours. In the evening, when we couldn't hear the Lithuanians

197 J. Leociak, Tekst... [Text...], p. 233.

198 L. Najberg, Ostatni powstańcy getta [Last Ghetto Insurgents], Warsaw 1993, p. 91.

199 J. Leociak, Tekst... [Text...], p. 236. 
swearing anymore, the woman gave me a sign. We have started crawling towards the forest" ${ }^{200}$. Tima Kac and I. Kogan saved themselves from Ponary in a similar way $^{201}$. A study by Andrzej Żbikowski on the accounts of the female escapees from a mass grave in Poniatowa - Ludwika Fiszerowa and Estera Rubinszte$\mathrm{jn}^{202}$ - lets us treat such cases not as isolated and extraordinary, but rather as a separate category of a hiding place.

\section{Solitary - collective hiding places}

The notion of "solitude" should be treated literally here, in the sense of physical presence of lack of other people hiding. When reading the accounts, one can notice that in an extreme situation - in an experience of a hiding place - a human being is always alone. It mainly concerns the psychological sense of loneliness, missing the loved ones, awareness of the fact that one cannot expect comfort and support from the fellow hiding people, since they are in an equally bad situation. It is also a matter of lack of solidarity, as exhibited by throwing somebody out of the hideout, harassment, or even, in drastic cases, murdering people posing an actual or imaginary threat. If the hiding people were a family or a group of close friends, it was possible to avoid that feeling of alienation. The story of Henryk Schönker may serve as an example. He often stressed that all the members of the family provided support for each other and showed love toward one another. However, a group composed of strangers, often randomly assembled, was typically a platform of severe antagonisms.

However, I have decided to focus on the "physical" comprehension of loneliness and simply identify as "solitary" those hiding places, where only one person would hide.

\section{Solitary hiding places}

Solitary hiding places are a common occurrence amongst the temporary hideouts - presence of others was not indispensable to survive in hiding for a short period of time. Moreover, a single person was less under threat of being exposed because of the actions of the fellow people hiding: them making noise or their reckless moves. Sometimes it was impossible to hide a whole family, while even a small piece of space, literally measured in centimeters, was enough for a single

200 R. Korczak, Płamia nad piepłom, in: Życie i zagłada... [Life and Holocaust...], p. 541.

201 Ibid., pp. 542-544.

202 A. Żbikowski, Teksty pogrzebane... [Texts buried...]. 
person to hide for a short time. Therefore, it often happened that just one person from a family was left after an action, just like Genia from the Lviv Ghetto, who told Janina Masłowska: "They took my mom, my little brother and everybody else, and I hid in a bush and they have looked me over, and then the action stopped"203.

When it comes to long term hiding places, the cases of staying in a solitary hideout without outside help are extremely rare. In fact, they can be found only among the "Robinson Crusoes" described above. They were able to come up with food and water themselves instead of getting help from other people; they would explore the space around them on their own (e.g. ruins of Warsaw destroyed after the Uprising), searching for the items they needed. There were, by contrast, aided solitary hiding places. Woodland bunker of Florian Majewski, who survived a few months alone in a forest, with a help of his friends from a nearby village, can be an example of that. A separate, very frequently occurring model is a solitary hideout "under the same roof", where a family had a space for one person only. In such cases people were not technically alone, as they lived on the premises of one farm or household with their hosts. However, their hideout can be treated as solitary, as they were the only people with a status of a fugitive in the group to which they belonged. In case of there being a "hideout within a hideout" prepared in a home just in case, only they had to descend there and wait out the danger.

On the one hand, the solitary hiding places are free from many difficulties of collective hideouts, but on the other hand, they seem to be a very difficult existential experience. After all, the residents of collective hiding places felt socially alone, experienced isolation and exclusion, yet they had each other - and in difficult times even the physical presence of another human being could prove invaluable. It is true that there is no issue of overcrowding in a solitary hiding place (although the problem of scarcity of space might be present there), the person hiding has the whole space and all the collected goods at his or her disposal. There are no conflicts of interests, authorities or rules regulating the collective life. However, there are still the loneliness and awareness of being on one's own.

\section{Collective hiding places}

A group of people hiding together could have been formed completely by chance, it could have also been intentionally created in order to find a hiding place and to support each other. It could have consisted of friends, neighbors from one tenement or village, members of a family or strangers. Such a group would function

203 J. Masłowska, Relacja [Testimony], in: Życie i zagłada... [Life and Holocaust...], p. 280. 
differently each time. One could enumerate many differentiating factors, but the most important ones seem to be:

- conditions of hiding, especially the tightness of space in a hideout;

- external conditions, i.e. whether the hideout was located e.g. in a ghetto during an action or in some more peaceful place;

- the level of internal differentiation of the members of the group (e.g. as regards the wealth);

- in case of aided hiding places: potential relations with the helping person, who could favor one person from the group or not tolerate another.

A specific situation could arise if a person from the outside joined an already existing hideout. If it was, for example, a member of the family who was missing or believed to have been killed, that person's showing up would bring joy. However, if that person was a random person, the situation was much more difficult: the group in hiding would begin to fear exposure, to feel animosity toward another person in an overcrowded shelter, which could have even lead to aggression toward the newcomer. Collective hiding places took various forms:

- bunkers (e.g. within a ghetto)

- woodland dugouts,

- shelters prepared for the duration of displacement actions,

- shelters at people's homes (homestead).

Presence of several people always triggers the mechanisms of power, inequities arise and generate conflicts. A collective hideout is harder to set up and easier to expose. Yet even if no conflict arose, simply being cramped on a tight surface, in difficult conditions, in a claustrophobic space, without being able to go out, lead people to become bundles of nerves and overreact to minor incidents. Cases of killing cohabitants of hiding places, both children and adults, to minimize a risk of unwanted noises (cough, baby crying) could be an example of the above statement. Descriptions of such cases are present in a relatively large amount of testimonies. I am now citing Stella Fidelseid ${ }^{204}$, who was hiding in a bunker at Wołyńska Street in the first days of the Warsaw Ghetto Uprising: "We hear Fred's infant mewling, it must be very hungry or wet. People are whispering curses 'the baby will doom us', 'we have to strangle it'. Some shuffle, struggle. After a few minutes, it's completely quiet..." When the German footsteps in the street above

204 S. Fidelseid, Pozostatam w gruzach... [I have stayed in the rubble...], "Nasze Słowo" 1947, No. 19 (31); 1948, No. 1 (32), 2 (33), 3 (34), 4 (35); other issue: "Kwartalnik Historii Żydów" [Jewish History Quarterly] 2003, No. 2 (206), No. 4 (408). 
the bunker taper off, somebody has to get rid of the baby's body. "When one of the neighbors saw me getting ready to go out, she passed me some bundle. I looked at it and recognized Fred's baby. It's dead, it has to be taken out of here. I put it under my arm - it's strangely light - and start to climb the ladder towards the exit. [...] I have thrown the little corpse into some burning basement".

Putting up with other people's insanities was especially difficult. Such a situation (when the co-residents of a hiding place have killed somebody as well) is described by Masza Groll from Brest on the Bug River. During an action in the Brest Ghetto, $15^{\text {th }}$ October 1942, Masza and her family were hiding in a shelter. "We had a shelter under a pig pen, we'd go inside there from the apartment. The shelter was calculated to accommodate 6 people, but after a short time from the beginning of the action, 17 got inside. We couldn't do anything about it, as, just after we hid, the Nazis were already in our yard and took away the people who were there. We have spent the first day without a drop of water. At night my father went out, he managed to find some water. Each person could have one sip. Everybody was making sure that the drinking people were not exceeding their norm; it is hard to describe the fights, the horrid scenes that happened then. One mother passed on her sip to give it to her 3-years-old daughter. On the third day, everybody was showing signs of madness. 50-years-old Chawa Mans was screaming so badly, that they had to strangle her, or she would blow everybody's cover. Others were stripping naked. My brother started tugging my hair, he thought it was a cat. I came out of that shelter at night and went to a Pole I knew, Janina Grzegrzółka from Brest, who then kept me safe for a few days" 205 . Hardships often intensified as the number of the hiding people grew. Crowds, stuffiness, problems with the discipline, orderliness, and establishing rules that would apply to everybody occurred both in bunkers and in hideouts in somebody's flat.

Collective hiding places, which were often being constructed for months through efforts of many people, were able to achieve the highest level of technical rationalization. Accounts are known of ingeniously constructed bunkers for a hundred of people, with additional rooms and all possible amenities. Here is how doctor Polisiuk described a hospital bunker on the day before the breakout of the Warsaw Ghetto Uprising: "From the very morning there was a great unrest in the district. Disturbing rumors are spreading that there is going to be a displacement action and 400 MPs having been mobilized on Monday for that purpose. [...] Final preparations to getting 'walled in'. [...] In the last months, the employees

205 M. Groll, Relacja [Testimony], in: Życie i zagłada... [Life and Holocaust...], pp. 556-557. 
have created six hiding places in the underground of the hospital. 400 people found a place for them in those so-called shelters (hospital's employees, their families and friends). Our group, consisting of 130 people, occupied a shelter which was considered to be model. Mr. Górwicz was its leader and, at the same time, its creator. [...] Our actual shelter was located under ruins of a home at 3 Gęsia Street (a home, which was bombed during military actions in 1939), i.e. behind the inner wall which went through the middle of Gęsia Street. [...] The shelter consisted of 16 unearthed basements connected in a corridor system. Each basement was calculated to accommodate 10 people, there were also a food storage unit, pharmacy, kitchen, two restrooms with running water, electric light, gas and water were connected from the main pipes under the roadway. 2-people bunks in the 'rooms'. 4-lamp radio and 2 'broomsticks' in the hands of the management. Hygiene conditions are generally passable"206. The author of the account spent almost a month in the shelter (on $13^{\text {th }}$ May 1943, he decided to get through to the "Aryan side"). During that time those "passable" conditions deteriorated, maintaining hygiene became impossible, but the efforts of the designers of the shelter, who adapted such a large number of rooms to serve as a shelter, are awe-inspiring.

\section{Wandering - looking for a hiding place}

A hiding place, the various characteristics of which I have presented above, was never an obvious, predetermined thing. Such a place was desired, yet hard to obtain. There were a lot people who wanted to hide, and good - safe, cheap, comfortable hiding places - not that many. There have been times that people already had prearranged places to go and addresses when they were getting out of ghettos. However, it also often happened that, when escaping death, one would go wandering, not knowing where to spend the next night. I have distinguished a separate category "wandering - looking for a hiding place" to stress how big of a part of the experience of hiding oneself had those exact intervals, being so difficult to describe, so frustrating and terrifying. A hideout, even the least secure one, was still giving a minimum of stability, could become someone's ersatz of their own place on Earth. A person wandering around in search for a hiding place, have not had such a place yet; that person had no guarantee of finding it and saving his or her life.

Very young Dwojra Frymet from Volodymyr-Volynskyi described her experience of wandering in search of a permanent place to stay: "I was going through a

206 AJHI, 301/5061, Testimony of Polisiuk. 
horrible time in my life after the pogroms. I lived in atrocious conditions. I had to hide from the Ukrainians in pits, potato fields. At nights, the Poles would give me food. I got all lousy from all that wandering. I once hid in a barn, so they wouldn't find me. I have almost poked out my eyes out with blades of straw, I once hid in a field full of lupine. There was a handful of Jews hiding there. Somebody said that some Pole has told on us. The Jews ran from that field to a forest. I have stayed alone, I didn't want to run with them, because I thought I would be better off hiding by myself" 207 .

Countless hiding places: with farmers, using Aryan papers, in a forest, in a country barn, in a ghetto - were saving life of the previously cited Zofia Dulman. In December of 1943, it turned out that a house in Trościanka near VolodymyrVolynskyi, where she was staying, got surrounded by the Germans. Instead of hiding and waiting out the danger, Zofia has instinctively chosen wandering. "Without a second thought, I took the kid by the hand and got on moving. Penniless, in torn men's shoes on my feet and in a patched-up jacket on my back. I didn't know where we were going myself. We were wading through the snow the whole day. We were walking down the road to Volodymyr, so a dangerous road, since they have conducted the final liquidation of the ghetto and it was full of Germans and Ukrainians everywhere. They were tracking the few Jews who were still hiding" ${ }^{208}$. Zofia and her daughter were hiding for seven days in a barn of farmers in Kolendowo, but soon had to get out of there as well. "There was no place for us among the people. The good man gave me an old jacked, which I put on the child and wrapped it with a rope instead of a belt, and a half of loaf of bread and a piece of lard. [...] I have picked up a stick and again went off into the world with Dana on a December night. The moon was shining, the frost was icy. That night it was 30 degrees below zero and I and my child had nowhere to go. [...] The villagers feared us like ghouls"209. In the quoted testimony, one could discern an anthropological topos of the Holy Family looking for a shelter at night...

A similar fate has befallen countless other people escaping ghettos, liquidation actions in towns, places of execution, transports or camps ${ }^{210}$. Wandering could have been ended with a promise of salvation when finding a long term hiding place, acquiring "Aryan papers", getting out of the territory of occupied Poland (heading east to USSR). There were times that wanderers distraught by a series of failures would come back to ghettos they left with a hope of improving

207 D. Frymet, Relacja... [Testimony...], p. 608.

208 Z. Dulman, Relacja... [Testimony...], p. 583.

209 Ibid.

210 M. Melchior, Uciekinierzy z gett... [Escapees...]. 
their lot. The wanderers would often die from the hands of the Germans or local people, would be sent to a concentration or a labor camp. Wandering was an interim stage, which could lead to miscellaneous situations.

A culture archetype perfectly fit to describe this phenomenon was brought up by Baruch Milch in his text. He described the situation in his town on the day before an "action": "Nobody could get anything out from Judenrat thugs. I have immediately informed the people I knew, hid the most important things from home, and left before the evening with a small bundle of the most important things. We all had one like that prepared in those days, just like the Wandering Jew"211. During the war, nearly every Polish Jew was exactly such a wanderer looking for a shelter.

In this experience, I see the most powerful allegory of homelessness and social exclusion of the Jews. I shall write more on the subject in Chapter 4. Here I wanted to signalize how certain concepts became relative in the most trying conditions. For the people looking for shelter a hiding place which they could not find was a promise of a home, respite, peace. Even though the conditions of sojourning in a hideout could have been penurious and precarious, it was not the person in a hiding place that was at rock bottom, but a homeless wanderer, with no place for oneself and excluded from all social structures.

\section{Summary}

Chapter 1 had an introductory and descriptive character - I wanted to present the conceivably wide spectrum of the described issue using a large number of diversified examples. It is true that each hiding place was different, but I hope that I was able to choose basic, objective criteria which allowed a typology to emerge from this multitude of examples. I differentiate the types of hiding places with regard to time spent in there, number of people, provided assistance and location in space. These features are easy to identify and find in a description presented by an author of a testimony. Each of those hiding places, aside from those abovementioned objective properties, has a set of more elusive and ambiguous features as well. In the following chapters I would like to analyze substances and meanings that lie within the space of a hiding place. Therefore, in Chapter 2, I shall describe a hiding place as a social space and the individual experience of the space of a hiding place.

211 B. Milch, Testament [Testament], Warsaw 2001, p. 131. 



\section{Hiding place as a space. Perspective of social and individual experience}

It is equally hard for the researchers of the Shoah and those of ancient cities to look into the world they are trying to describe. Despite significantly smaller time distance, and in case of Polish scientists - spatial proximity, the reality experienced by authors of wartime testimonies and memoirs is as distant to us as the antiquity. It is also harder to understand. Therefore, the scientists find support in various disciplines of humanities suggesting tools for analyses, categories and concepts.

In the introduction, I have invoked primary concepts of social sciences describing space. I have concluded that the humanistic perspective is the most valuable from the cognitive perspective, as it covers relations between human beings and space, and influence of shape of that space on relations between them. We should transpose this exact way of perceiving space to the wartime situation and attempt to analyze the space of a hiding place as a social space (the first part of this chapter) and a hiding place as a space in an individual experience (second part of the chapter).

Therefore, in the first part I am presenting the space of a hiding place from various perspectives, trying to describe its place in a social space. To recreate it, I am making use of Jewish testimonies and fragments of Polish memoirs and journals, which I counterbalance with extracts from a report by Friedrich Katzmann. The second part is an attempt to get out of a hiding place: a depiction of individually experiencing its space, solely from the hiding people's point of view. I back this analysis with theories of environmental psychology. I am presenting the two main elements of experiencing the space of a hiding place: spatial perception and environmental stress (violation of personal space, adverse environmental conditions). This part of the book is concluded with deliberations on the functioning of a body in the space of a hiding place and a reflection on the role of a biological compulsion in shaping of the social behaviors and individual experiences.

\section{Part I. Hiding place as a social space}

Distrust is the idea behind stashes. [...] I am talking about trinkets, but they are enough to understand the idea of a stash and I do not have to mention hiding places, which save a life of a human or an animal in an extremely dangerous situation. We build stashes 
in a hostile world. After all, they are always to protect something, no matter how great is the danger.

Jolanta Brach-Czaina ${ }^{212}$

The war and occupation are a time of chaos and violence, of imposed and dangerous power. The German authorities, according to Leszek Kołakowski, introduced (at least partially) a totalitarian system on Polish territories: "I am using the word 'totalitarian' in its commonly used sense, meaning a political system, in which all social connections were completely replaced by a government organization, and where all communities and all individuals have to function solely for purposes, which are both the purposes of the government and that are set by the government itself. In other words, a perfect totalitarian system would mean a complete destruction of civil society, making the government and its organizational units the only forms of social life; all kinds of human activity - economic, cultural, political, and intellectual - are permitted and mandatory (the distinction between what is permitted and what is mandatory is heading toward disintegration) only in the extent to which they are serving the purposes of the government (I reiterate: the purposes set by the government itself). Each individual, including the rulers themselves, is considered to be the property of the government" ${ }^{213}$. In this system, the Jews had a special place designated for them, in a figurative and literal sense. One can analyze the hiding places as a social space on two levels. On the first level, it is a construct of a social structure, which was shaped in a specific historical moment: during the rule of a totalitarian system imposed by the occupant. A need to create a hiding place is connected with there being a situation of endangerment of a social group "designated" by the Germans. Therefore, hiding places are being created as a product of the reality of the Shoah and this is, at the same time, their broad social and historical context.

On the second level a hiding place is a creation of particular people. We can use the following classification here:

- a hiding place as a creation of people hiding, who chose a given place and decide that it would serve as their shelter from that moment on;

- a hiding place as a creation of people hiding, who create it in a literal, physical sense, building it from the ground level up or significantly transforming a preexisting construction;

212 Brach-Czaina J., Błony umysłu [Mind Membranes], Warsaw 2003, p. 53.

213 L. Kołakowski, Czy diabeł może być zbawiony i 27 innych kazań [Can the Devil Be Saved and 27 Other Sermons], London 1984, p. 246. 
- a hiding place as a creation of people helping by building or transforming a space for somebody (those two perspectives connected with building a hideout will be presented in Chapter 4);

- a hiding place as a creation of people helping, who decide to let in a person looking for shelter into their space and therefore to change that space's meaning;

- a hiding place as a creation of people helping by pointing to a preexisting place, which is, however, not owned by them, and therefore they are not including the person hiding into their world ("Go hide there, you'll be able to spend a night there").

War (and the Shoah) is a terrifying kind of social transformation, which is a shock in a life of the society. It has all the makings of a traumatogenic transformation: it is sudden, has a broad scope, it is profound, radical, unexpected ${ }^{214}$. A hiding place as a social space understood in a broad sense is in a sense channeling the tension created in the society by the dramatic experiences of the Shoah. Witnesses of the Shoah have watched how the hiding Jews were vanishing from the face of the Earth on their won, they did not have to look at their horrid fate, as their lives were moving to a hidden sphere. They seize functioning openly, thus resolving the issues the witnesses had: their guilt, helplessness against the harm done to their fellow citizens, conflicted conscience or fear of the consequences for helping somebody. They disappear in a way allowing others to be indifferent. The process of the tormented people descending into hiding places caused a temporal "cover up" of the social trauma experienced by the witnesses of the Holocaust. However, it was not an effective solution, and that is why, according to a number of authors ${ }^{215}$, an unhealed trauma can keep resurfacing for decades to come.

A hiding place is on a different level of a socially created space - because it is located "somewhere": in the countryside, in a city, in a forest. It is on a territory of a given country, in an administrative unit. It is a piece of a wider area, created in a process of human activity. It is a social space also in a sense that it is characterized by a specific kind of human activities. It has its place in the functional division of space, it serves people. Those functions can be divided into primary and secondary. The primary function is to save life, to hide during an emergency. It is a function which is to satisfy the most primal human need ${ }^{216}-$ a need for

214 L. Kołakowski, Czy diabeł może być zbawiony i 27 innych kazań [Can the Devil Be Saved and 27 Other Sermons], London 1984, p. 246.

215 J. Tokarska $\neg$ Bakir, Rzeczy mgliste [Misty Things], Sejny 2004.

216 A.H. Maslow, Motivation and Personality, New York 1954, especially pp. 95-105. 
safety. If a hiding place performs that function, the secondary, more complex issues emerge. In almost every text on a long term hiding place, which is not an utterly extreme experience, there are mentions of various human activities performed in a hideout. First of all, this includes homemaking, i.e. preparing meals, tidying up. Another issue is connected with personal hygiene - shaving, cutting hair, bathing, doing laundry, and even exercising. In case of one resident of a hideout falling ill, it was necessary to nurse that person back to health, sometimes a doctor was called to see the patient (however, in the texts there are testimonies of killing sick people, who were a potential risk for the others). People, even strangers, bond with each other in hiding places, romantic attraction is not uncommon. People become couples, have sex, children are born (and die). In face of the vastness of time, boredom becomes a serious problem. An example of endearing innocence in face of this affliction can be a case of an elderly grandmother of Julian Aleksandrowicz. She was hiding in a shelter for the elderly "not realizing the gravity of the situation, she would send us notes saying, more or less: 'Get me out of here, I'm bored' [...] So the granny had to be bored for a few long months and wait till the war was over"217. Work was a way to be delivered from boredom. Some people hiding had a chance to get a job in cottage industry. For example, Leon Guz was manufacturing paper bags when in hiding, Guta Trokenheim-Szynowłoga and her daughter made brooms. Aleksandra Bańkowska wrote the following on how people used to earn a living while hiding in the woods: "It was not very common, but some Jews hiding in the woods were able to support themselves with work. Sometimes it would happen that the farmers, from whom the forest collective was getting food, would order an applicable service from a member of the group who was a tailor, shoemaker, furrier or a tanner. [...] Shoemakers and tailors were employed in partisan divisions as well. Sometimes they would become important figures, like Lejzor Port, who was the only tailor in Frunze division of Kirow brigade and was carefully protected by the soldiers from any dangers. Various services were an important task and sometimes even the purpose of there being civilian camps around the partisans. In Bielski's camp, people worked in various shops. There were shoemakers, tailors, carpenters, blacksmiths, tanners, cold cuts makers, and even weapon repairmen. People were also able to work as cooks, physicians, nurses and even secretaries with the partisans or in the civilian camps"218. Sometimes it was also

217 J. Aleksandrowicz, Kartki z dziennika Doktora Twardego [Pages from Doctor Twardy's Journal], Cracow-Wrocław 1983, p. 61.

218 A. Bańkowska, Las jako miejsce przetrwania... [Forest as a Place of Surviving...], p. 55. 
possible to study while in hiding, to read (newspapers with current news were especially in demand), many people wrote journals and even, in better conditions, people would engage in scientific work (Emanuel Ringelblum or Julian Aleksandrowicz). Playing cards (mentioned by e.g. Menachem Katz, Chaim Icel Goldstein) were a basic, safe, and easy entertainment, as well as other games (people in Ignacy Chiger's hideout used to play City-Country-River). A bondforming social activity and a good way to pass the time the people would engage in was telling stories - but only when it was not necessary to keep quiet. People would also simply talk, reminisce. There were also more sophisticated ways to kill time, one of which is mentioned by Leokadia Silverstein: "The idea was simple and brilliant - from that moment forward the time between the meals was filled with lectures, which were prepared by somebody else each time. We could choose any subject - and tell true or made up stories"219.

A hiding place is a piece of the world that has to contain the whole world inside itself. It is a part taking up the role of the whole. People sentenced to death, postponing the execution date by locking themselves in a hideout, lose their entire world. They are losing all the other places and spaces. There is an infinite number of places where they cannot go. The one place, those people are in is also branded with "I can't, I'm not allowed". I am not allowed here, I am not allowed to live at all. And yet, for some reason those people assume that this particular place can be exempt from that general prohibition. It can be detached from the system, where the prohibition is in force, and transferred to an alternative reality. To the underground. That is what a hiding place is. It is a paradox, if we assume the point of view of the executioner, the legislator who's sentencing a whole group of people to non-existence, to be binding. A hiding place allows for existence, even though it should not exist itself. It is prohibited as well. It is a scratch on an armor of repression, a hole in the system of total control. It exists through denial - thanks to the fact that people do not know about it, and until they find out. A hiding place is doomed to be destroyed if it is no longer invisible. Due to its fragile status, it is not a guarantee; it is just an attempt and a possibility. It is an attempt to sneak away. A grab for freedom. "Granting a person the right to be present in some space becomes a part of that person's social status", wrote Florian Znaniecki in 1938. The Jews were initially granted a right to be present in ghettos. That right was later revoked. Their social status disappeared, as they were destined to die. Jews choosing a hiding place were granting themselves a right to be in there or were sometimes given such a right from their "Aryan" guardians. That

219 L. Silverstein, Tak właśnie było... [That's What Happened], p. 168. 
right was contradicting the occupant's laws. For Znaniecki a space has value, it is an element of a wider system of values. In this understanding, a hiding place has a value as a protest against the Germans, an attempt to take away a fragment of a space from their jurisdiction. It is a part of an illegal, excluded, and, in some way, free world. The people hiding were resisting by choosing a hiding place. A person giving somebody shelter was joining that fight as well.

And yet a hiding place is so very limiting. Basic physical categories are not allowing performance of majority of tasks. Even if a hiding place, which should not exist at all, is exempt from the occupant's prohibitions, we should note that for safety reasons an internal list of prohibitions and restrictions has to be created. Keeping the state of invisibility is a crucial issue - the state of existence without anybody knowing it is there. A hiding place should be actually located "nowhere", that would be an ideal position. A person hiding is a Nobody. "No living thing dares to know about Nobody. No man, no authority, not even a good old dog"220. To make it so, a lot more things are prohibited than allowed. That is the first limitation. Above all a hiding place is limiting by itself, as one has to be inside it and cannot go out. That is the second limitation. Therefore, there is no more home, work, street, temple, bathhouse, market or forest for a person in a hiding place. A hiding place becomes that person's whole world. It has to assume the function of all the other, now inaccessible, places. The functions that cannot be assumed have to be suspended or be carried out in the psyche, in one's mind. A hideout as a place can be described using various categories. By analyzing location, direction and availability ${ }^{221}$, we will see that not all of them will be equally useful when applied to the phenomenon of hiding places. Some will clarify a lot, some are not connected with this specific space at all, as they seem to belong to a different order. Only the category of distance will be described in relation to a sociological perspective. It seems that the other ones correspond more smoothly with an anthropological perspective and will be therefore described in Chapter 3 .

Location is determining the distance; it is always presented with respect to something else. One can measure that distance in the simplest physical units. It can have a social character. In such a case, regardless of physical proximity, the distance between groups or individuals in a given space can be enormous. "A sense of distance is closely related to an ability to traverse it, which, in turn, depends both on biological and social characteristics of an individual. [...] For people with an important position in a social hierarchy traversing [...] a few

220 J. Aleksandrowicz, Kartki z dziennika... [Pages from Doctor Twardy's...], p. 54.

221 See B. Jałowiecki, M. Szczepański, Miasto i przestrzeń... [City and Space in...]. 
thousands of kilometers is not a big deal. Spatial mobility depends not only on social position, but also on other characteristics of an individual, such as gender, age and profession"222. The distance between closed off hiding places and the outside reality was therefore immeasurable. It was not falling into the scope of social status so much, as it was into incomparably sharper categories. One can say that from the Germans' point of view a Jew sentenced to death had no social status at all. Therefore, abandoning a lawlessly chosen "niche in the system", where a person had a chance to survive, and going even the smallest physical distance was possible, yet carrying a risk of death. When it comes to individual characteristics, from a rational standpoint, young people, women and those who were not externally "alike", surely had a bigger chance of safely traversing such a distance. However, even the best set of characteristics was not guaranteeing safety. Therefore - in practice - every distance was infinite for those in hiding.

Isolation of the people in hiding was one of the most difficult elements of their experience. They were not able to freely cross a physical border, but there were ways to cross it in a figurative way. First of all, these included visits of people from the outside, who would bring news about the world and a breath of freedom. Secondly - letters. Chanina Malachi ${ }^{223}$, who was hiding in a small house outside of Warsaw, described impatiently looking forward to a visit or a letter from his wife Hindzia, who had Aryan papers, or other people he knew and with whom he was able to corresponding for the whole time when he was hiding. Thirdly - reading, especially press, which would make the farthest expanses seem a lot closer. News from the front were especially popular. Books were also helping to forget the tightness of the walls of a hiding place. A universal measure that was available when one could not rely on company or reading, was transcending the limits of a hiding place with one's mind, trying to remember about what is still there on the outside. Chaim Icel Goldstein said the following in his memoirs: "We were cut off from the world in that hideout... [...] What should we do? [...] Hold on with all our might to the world which exists outside of our hiding place and over ruins of Warsaw. Imagine that there is a vibrant world that is worth living"224. Such a therapeutic role could have been performed both by stories of fellow people in a hiding place, which would open up spaces unknown to the others, by memories of life before the war, and by plans for the future, which were also exceeding the scope of a particular space.

222 Ibid., p. 310.

223 AYV 03/3379, Journal of Hinda and Chanina Malachi.

224 C.I. Goldstein, Bunkier... [Bunker], p. 28. 
One can also perceive a hiding place as a territory. The idea of territoriality derived from biological sciences has functioned in social sciences from around the 60s. "The term of 'territory', according to the most representative definition proposed by Sommer, means a geographical area, which, by personalization (personal marking) and physical flagging becomes secured from a breach. As it can be seen from that, a territory is a space that is constant and independent from a human completely, but having influence on behaviors. Both the previously mentioned definition and a number of other ones have a common constant element, which is connected with a defensive behavior. An essence of a territory is therefore an idea of protective separation that is determining specific territorial behavior in a given area (territory)"225. A hiding place is, however, a specific type of a territory - it is a deficient. It is represented by a person's limited sense of control over the hiding place. In majority of cases the hideouts are defenseless against external threats (partisan camps and hiding places of insurgents are an exception here).

What is more, people occupying a hideout had no rights to such a place. Even if it was built by their own hands and paid for with their money, created in their home or if they were invited to a hiding place by a friend or a family member. It is so because a hideout exists in a scope of illegality. Any potential rights can have a low-level and informal character: the person hiding was granted a right to stay in a hiding place by the owners of a place (Poles) or fellow people hiding (other Jews). This person would not get such a right from the authorities, who were in fact running the whole space of the occupied Poland (the Germans). This is why a hiding place is a space of distrust, as a person occupying it cannot permanently believe in any guarantees or promises.

A hiding place can be viewed as a space for social interactions. In general, choosing to hide meant opting to disappear from the social world. A person hiding cannot by definition, get in touch with other people. That person is pretending to not exist. Such people are excluding themselves from interactions as if they were dead or were never born. They do not want to be considered, wish to be forgotten and unnoticed. A category of invisibility becomes an agent here. It is selective, as situations, in which a person survived as a complete hermit, without contacting anybody, were very rare. Therefore, there were exceptions from invisibility. Obviously, a person was visible for potential co-residents of a hiding place. For the guardians, who were helping such people, who provided them with food and invited them into their home. Yet this was not always the case, as it could

225 A. Bańka, Społeczna psychologia... [Social Psychology...], p. 161; reference to: R. Sommer, Personal Space..., p. 33. 
have happened that a guardian was aware of only some of the residents of a hiding place, and the others would hide from that guardian as well. Some visitors from the outside: a doctor, relative or a friend, a member of an organization could see the hiding people, but they had to be invisible for everybody else. Potentially dangerous interactions had to be postponed to some unspecified "later" - when everything changes.

Moreover, a hiding place is a social definition of a hiding Jew. It determines the Jew's position in the social structure precisely as this "Nobody" who should disappear, but does not; the unwanted, unsafe, endangering others with his or her presence. From the minute of descending into the space of a hiding place, people lose their previous characteristics. They are no longer workers, as they do not have a job anymore. They are not family members, if their family has not arrived to the same place. Their appearance, personality, interests, talents - everything that defined them as human beings is no longer important. The technical aspects become relevant - do they cough? Are they strong, durable, patient? Questions of metaphysical order, which are unverifiable, but significant - are they lucky or a jinx? The peoples' past does not matter anymore. From that moment forward the present and the future will consist of waiting and reducing oneself to vita minima ${ }^{226}$. Hiding becomes the nature of people in a hiding place. And they still remain Jewish. Convicts with postponed sentences. This mechanism is perfectly illustrated in an account by a Pole, Helena Grabarek, who was sheltering Abram Grinbaum (Jan Abram Grymbał wrote about him) in her farmyard in a village near Gąbin. Grinbaum stayed with her from 1942 till the end of the war. He had a hideout in a barn. Here is how the author of the account is describing the sudden change in Grinbaum's status when the war ended: "Then in the morning of $18^{\text {th }}$ January 1945, at 10 o'clock in the morning, we saw Russian tanks. We were really happy that we lived to be free and Jan Grymbał rejoiced too that the sun shone for him as well, as he was not allowed to even see the sun for three years. And now he's somebody, just like everybody else, and he can walk about this world"227. In this simple woman's intuitive perception of social reality, "Grymbał" staying in a hiding place had no rights, and became "somebody" equal to other members of the society only after he came out.

One can wonder to what extent the specifics of a hiding place were influencing the scarce interactions taking place inside. "In direct interactions, not only the distance can be of importance, but also the spatial constraints, shape, form

226 See J. Aleksandrowicz, Kartki z dziennika... [Pages from...].

227 AJHI, 301/5149, Testimony of Helena Grabarek. 
of the surroundings, in which those interactions take place. Sometimes those characteristics expedite or, on the contrary, impede contact; they increase or decrease chances for establishing interactions, give them a particular form"228. It is not easy to draw conclusions leading to some rules from analysis of individual testimonies. However, we can note some general observations.

The majority of interactions belongs to the category of direct ones, which require simultaneous presence of their participants in time and space. The exception includes handing over letters, news and items by third parties. Inside a hiding place the interactions are subject to a tense atmosphere stemming from danger and having no way out. Density of the space causes a behavioral sink to form between the people (I shall write more on the issue in the second part of the chapter). Co-residents are keeping each other in check, they are all in the same boat, but somebody can get fed up, stop caring and do something that will endanger everybody. There are also the typical relations within a group, conflicts regarding money, power and so on. In turn, a dependency is created in relation to the outside world (potential people helping). Not being able to fully decide for one can cause a hiding person to become a part of a dominance-subordination relationship with the helping person (I wrote about it in Chapter 1, in the section on assisted hiding places).

From a sociological perspective, a hiding place can be understood as a space for everyday life - in its paradoxical, wartime variety. A place to live in on a daily basis, to face practical everyday challenges, and carry out one's social roles in extraordinary conditions and circumstances. One could also see a hiding place as falling into a contradictory category, as a space for extreme, boundary ${ }^{229}$ situations, which rip a person away from normal everyday life. Among boundary situations Jaspers lists suffering, struggle, death, chance and guilt. After all, a hiding place is a space of suffering, death and fear of death. It is an experience of chance - due to its frailty and precarious security, the situation inside it gets out of control. It is an experience of guilt - as the thoughts in a hiding place often circle back to those who were unable to hide. Jacek Leociak in a text on bombings analyzed as boundary situations ${ }^{230}$ brings up other theoreticians

228 P. Sztompka, Socjologia... [Sociology...], pp. 70-71.

229 See K. Jaspers, Philosophy of Existence, trans. R.F. Grabay, Philadelphia 1971.

230 J. Leociak, Bombardowania miast jako doświadczenie graniczne [City Bombings as a Border Experience], in: Wojna. Doświadczenie i zapis. Nowe źródła, problemy, metody badawcze [War. Experience and Records. New Sources, Issues, Research Methods], eds. S. Buryła, P. Rodak, Cracow 2006. 
working within this area. He mentions Bruno Bettelheim ${ }^{231}$, who uses a concept of extreme (boundary) situation. In such a situation, a helpless person is highly vulnerable. Such an experience has a devastating effect on a person's psyche. Another author cited by Leociak, Dominick LaCapra ${ }^{232}$, calls the Shoah a limit event, filled with violence, making it impossible for old values and structures to survive. In conclusion Leociak, invoking Jan Strzelecki, formulates his own definition: "a boundary experience occurs when a person is unable to bear some situation anymore, but has no other choice - and bears it" ${ }^{233}$. It would seem that a hiding place has to be perceived as a potentially extreme space. After all, there were various kinds of hiding places, also ones where it was relatively peaceful, where people experienced positive feelings, care, good conditions. However, we have to remember that a wartime reality was characterized by substantial dynamism and a place which was peaceful one minute could suddenly become dangerous, filled with terror and uncertainty. The distance between space of everyday life and the space of boundary situations was therefore very short in wartime conditions; this concerns not only the hiding places, but other places as well.

In wartime reality, a hiding place functions as a new element of social space, as it generates previously unknown opportunities for relations between individual people and social groups. Jacek Kaczmarek wrote: "Changes in ways of life cause transformations in organization of space, and the reorganization of space influences transformations of social reality" ${ }^{234}$. Even though nobody was supposed to know that hiding places existed, everybody knew. Despite the fact that the majority of society was probably indifferent to the fate of Jews, information about them were generally circulated. Hiding places were ascribed to the category of unwanted space, marked as negative and problematic. Those were the places ascribed to a stigmatized social group and at the same time another transitional phase between prewar presence of the Jews in social space and their complete disappearance. Theoretically, upon going "underground", the Jews were vanishing out of sight of not only Germans, but their Polish neighbors as well. However, people knew they were there, even often knew where the hiding places were. The hiding people had an unstable status of being illegal, in need of help, deprived of rights and resources, which would constitute their influence and position in the

231 B. Bettelheim, Individual and Mass Behavior in Extreme Situations, "Journal of Abnormal and Social Psychology" 1943, No. 38; Surviving, and Other Essays, New York 1979.

232 D. LaCapra, Writing History, Writing Trauma, Baltimore 2001.

233 J. Leociak, Bombardowania miast..., [City Bombings...] p. 183.

234 J. Kaczmarek, Podejście geobiograficzne..., [Geobiographical Approach...] p. 49. 
social hierarchy. This status would open various perspectives, which were often negative for people living in hiding places.

The issue of German perspective, which could not but have an effect on Polish perspective, is worth deliberating. A hiding place seen from the outside by the Germans had to appear not as something that should be pondered, but simply as a place that had to be destroyed. The hiding places should not exist at all in the German order. Since they already existed, destroying them was another task to perform, which was difficult, unrewarding, and even dangerous for them. In order to do it, aside from engaging their own troops, they were employing local people, by not only threatening to punish them for helping the Jews, but also by enticing them with rewards for discovering Jewish hideouts. A sample of the German perspective on the hiding places is a report by Friedrich Katzmann, a co-orchestrator of operation "Reinhardt", SS and police Commander in Galicia district. A fragment of that report is worth quoting, as it gives an idea of how objectified the hiding places were and how task oriented were the Germans in regard to them - they saw it as a sign of reprehensible and incomprehensive Jewish resistance. Katzmann wrote the following on liquidation of ghettos in Rava-Ruska and Rohatyn: "The troops taking part in the operation were constantly exposed to physical and psychological exertion. To get inside the Jewish hiding places, cradles of filth and disease, they had to overcome their disgust. [...] During the operation, there were truly unbelievable difficulties, as the Jews were trying to avoid displacement with all the means they had. They were trying to escape, and even hid in the most unbelievable recesses, in drainage channels, chimneys, septic tanks and so on. They would barricade themselves in underground passages, basements converted into bunkers, dugouts, elaborate hiding places under floors, in sheds, furniture etc." ${ }^{235}$. Later in the report Katzmann describes bunkers "with masterfully masked entrances" and, in much detail, three giant shelters in Rohatyn, which he writes about using qualitative expressions as well ("expertly stamped"). The report is complimented by a large number of photographs documenting the appearance of the uncovered hiding places. The description ends with a statement that at the end of the operation "fire was set [to one of the bunkers] and they [the Jews] were smoked out"236.

In connection to the penalties imposed by the occupant for helping the Jews hide and because of the common animosity of the community, non-Jewish

235 F. Katzmann, Rozwiązanie kwestii żydowskiej w dystrykcie Galicja. Lösung der Judenfrage im Distrikt Galizien [Solution to the Jewish Question in Galicia District], Warsaw 2001, pp. 43, 50.

236 Ibid., p. 60. 
caretakers of the hiding places had to see them through the prism of the danger connected thereto, as something like a bomb with a delayed fuse. It would therefore happen that people would suddenly decide to defuse that bomb by getting rid of its residents from the closest proximity, even though the assisted hiding places were often a steady and beneficial source of income. Hence, a hiding place is a space for a relationship of exchange, always more advantageous for the nonJewish side, which, by having an infinitely more room for maneuver, has control over the situation and dictates the terms, due to having a power over the people hiding. (I wrote in more detail about the aid and various issues connected with assisted hiding places in Chapter 1). It is also a space of risk, fear, potential death, just as many other forbidden and illegal spaces. For others, who were not contributing to helping the hiding people, knowing about a hideout could become a trump card, it could allow one to gain an advantage useful for the purposes of blackmail. Finally, a hiding place was often the space of crime. Article by Alina Skibińska and Jakub Petelewicz entitled Udział Polaków w zbrodniach na Żydach na prowincji 167 ccomp świętokrzyskiego [The Role of Poles in Crimes against Jews in the Province of Świętokrzyski Region] ${ }^{237}$ sheds some light on this tabooed layer of the past. The authors were primarily drawing on the source material consisting of the trial files of the so-called August decree (from 1944, ordering to punish inter alia "fascist-Nazi criminals guilty of murdering and abusing civilians and prisoners of war"). Among the crimes punishable under this decree the most important ones included denouncing Jewish hiding places, direct and personal participation in hunting the hiding people, direct and personal participation in a murder and denouncing Poles who were helping the Jews. People who committed such crimes were sometimes inspired or even compelled by the Germans, blue police, or simply a certain group which, for some reason, would take initiative. The authors point the motives to include profits (or envy in case of somebody else profiting), scores between neighbors, compliance with the authorities, anti-Semitism, fear for one's own life.

While analyzing such crimes case-by-case, the authors are trying to decipher their social mechanism. The hiding Jews would often unknowingly get caught in conflicts between villagers and fall victims to them. It would seem that the key aspect was not keeping the existence of a hiding place a secret, but a sort of conspiracy of silence. As long as everybody knew about a hiding place, but not talked about it and pretended not to know, helping the people inside it was not a problem. A hiding place was not affecting the balance of a society as long as it stayed "in its

237 A. Skibińska, J. Petelewicz, Udział Polaków... [Participation of Poles...]. 
place", i.e. in the realm of secrecy. In contrast, a fact of publicly revealing this inconvenient knowledge would trigger an avalanche of irreversible events, during which even the people initially helping the Jews would cross to the side of the executioners. "A kind of psychological 'binding' of the participants of such events would occur. Compelled by fear for their own life, they would give in to blackmail with little resistance and not object to the people initiating actions to apprehend the Jews, rob them and finally take their lives. They would become contributors to those criminal acts themselves. A fear of mutual denunciation or even future blackmail because of defying the orders of the occupant was often a sufficient condition for the people, even the ones who were casual witnesses of revealing the presence of the Jews in a village, to become participants in the events that would play out afterwards" 238 . Such crimes are social matters; they are almost never committed by individuals. A crowd takes part in them - it is sinister, but still not anonymous. Everybody knows each other in a village, so in a sense everybody is keeping everybody else as a hostage. The authors of the text point to the circumstances enabling committing a crime to be, among other things, the commonly known psychological properties of the crowd (referring to e.g. the classical findings of Le Bon).

Probably, the majority of people not connected with hiding places in any personal way were treating them with the same indifference as they would treat the fate of the Jews in general. It is present in literature - after researching Polish journals and memoirs, Feliks Tych concluded: "We will probably never know in how many cases the disappearance of the Jewish subject from a large amount of wartime memoirs stemmed from complete indifference to Jewish fate, and in how many from a desire to suppress some traumatic experience or from moral discomfort. The silence is in general - in the light of the journals read for the purposes of this research - the most capacious category of attitudes of non-Jewish witnesses of the Shoah $[\ldots]^{{ }^{239}}$. The author enumerates the texts positively standing out from this indifferent model - testimonies of Monika Żeromska ${ }^{240}$, Tadeusz Pankiewicz ${ }^{241}$, or the texts included in Bartoszewski’s and Lewinówna's repertory ${ }^{242}$.

238 Ibid.

239 F. Tych, Dtugi cień... [Long Shadow...], p. 27.

240 M. Żeromska, Wspomnień ciagg dalszy [Memoirs Continued], Warsaw 1994.

241 T. Pankiewicz, Apteka w getcie krakowskim [Pharmacy in Cracow Ghetto], Cracow 2003.

242 Ten jest $z$ ojczyzny mojej. Polacy z pomoca Żydom 1939-1945 [This One Is from My Homeland. Poles Helping Jews 1939-1945], prepared by W. Bartoszewski, Z. Lewinówna, Cracow 1969, Warsaw 2007. 
Until this day, the subjects connected to the Shoah are perceived as perplexing, even tabooed. This is mentioned by Skibińska and Petelewicz in their summary of research conducted as part of the project of oral history carried out through interviews with villagers who remembered the wartime. This phenomenon is common and noticed by almost every researcher. Probably, in a course of time, the hiding places were perceived as a natural part of the landscape and were not especially noticed. In Polish accounts and memoirs from the war, the issue of Jewish hiding places is not usually discussed at length, being simplified and perceived only from the perspective of personal participation in some event. I believe that an example from an interview with a Pole, Jadwiga Mach, a resident of Basznia Dolna near Lubaczów, is a classic sample of this way of perceiving the issue. In her story, the whole history of the Jews hiding in the area was concluded literally in a few sentences: "The ones who decided to hide would usually not end up well, i.e. with a bullet in the head in a roadside ditch. [...] A friend of my father's managed to sneak out. He was hiding in the woods. One evening he came to us and asked for something to eat. My father gave him a loaf of bread and something for the road. He would not come inside, he was afraid to bring harm to us. He set off to Piaski outpost and that was the last time we saw him. Later we found out that Haskiel was murdered. [...] We had no undertaker in the village or anybody who could take care of the dead bodies. The soldiers would usually pick just anybody who had a horse and carriage. It so happened that they told my father to take Haskiel to his resting place"243.

To conclude these considerations, an issue of Jewish hiding places as a part of the whole gray area present in the occupied Poland is worth mentioning. From the perspective of non-Jewish neighbors, the hiding places did not appear suddenly and out of thin air. For the people of that time they were not a strange, unusual or surprising phenomenon, but - as one could suspect - another variety of something already known. The war, time of confusion, new legal regulations and ever-present danger forced various groups and categories of people, not only Jews, to hide. The concept of hiding can be very broadly understood - the whole conspired activity of Polish citizens was, after all, called an underground state, numerous people (not only Jews) assumed different identities, all activities prohibited by the occupant would to some extent go on in hiding. We can enumerate the following categories of hiding places used by the other citizens of occupied Poland:

243 http://www.zydzi.lubaczow.pl/index.php?kat=wspomnienia\&id=3. 
a) universal hiding places:

- during bombings in 1939 and at the end of the war, when the front line was moving;

- during roundups, after curfew, during transports on the territories occupied by USSR;

- in special moments in history (the Warsaw Uprising, Volhynia);

b) hiding places of particular categories of people:

- partisans of all groupings;

- members of Polish Underground State, emissaries from allied countries, people wanted by the occupant for some reason;

c) hiding places for objects (commodities for illegal trade; everyday objects under seizure, such as skies and furs; radio receivers; agricultural products hidden from the quota or partisans; objects connected with underground activities - documents and printing machinery, weapons; objects of national culture protected from being exported).

Placing Jewish hiding places against this back drop is once again calling to mind a thought of them being marginalized and excluded from the generally accepted order. A fragment of Jan Tomasz Gross's reflections is worth citing. He considers the biggest threat to Jewish hiding places to lie in the evil eyes of Poles: "a doorman, neighbor, a child playing ball in the yard or any passerby could tip the police"244. Later in his reasoning, Gross has even drawn the following hypothesis: "It might be enlightening to analyze in this respect the differences in reactions of the people to the fact of one being involved in conspiracy and reactions to being involved in helping the Jews. An underground operative was at risk of being denounced as well, the conspiracy also had to operate in the shadows. We probably convey the spirit of the age when we say that aside from Gestapo agents and collaborators, a vast majority of the society, if not directly involved, was at least supportive of the conspiracy. The exact opposite is true for helping the Jews: aside from the people who were actually involved in such activity, a vast majority of the society was against it or even hostile toward it. And so, for ex ample, in the occupation folklore there is plenty of stories and jokes about amateurish conspirators, stories about how youngsters in jackboots and girls with stuffed bags would go to the wrong floor, knock on the wrong door and mumble absurd passwords only for the initially amused $[\ldots]$ neighbor to walk them to the den, the existence of which should have been unknown to him at all. But he knew, and he was not the only

244 J.T. Gross, Upiorna dekada [Ghastly Decade], Cracow 2001, p. 49. 
one, and he was covering for it. I cannot recall from the literature I have read but one anecdote with the same pattern about hiding the Jews".

Similarly, while friends would boast their participation - either real or made up to impress somebody - in conspiracy operations, and therefore boost their image, nobody boasted sheltering the Jews. What is more, the people helping the Jews were expecting the worst from their neighbors even after the war and often their expectations would prove to be valid ${ }^{245}$. Gross states that the conspiracy was something to be proud of, a testimony to bravery, invention and panache, therefore was an activity that was positively evaluated by the society. Conversely, hiding the Jews, limited by equally strict sanctions by the occupant, was not commanding respect and the people involved in such activities were completely denied support from the society. Gross concluded: "that helping the Jews required exceptional heroism (in other words, that helping the Jews was so efficiently and brutally punished), and partially this is why the ban on helping the Jews - in contrast to other prohibitions, violation of which was punishable by death - was observed and only violated by relatively small amount of people. [...] Brutal repressions are easiest to use against a small a small group of people which is isolated in their own society" ${ }^{246}$. Consequently, a Jewish hiding place existed not only in spite of the norms imposed by the occupant. The existence of a hiding place was also not complying with the unspoken Polish social norms, was not carrying any positive values that accompanied other hiding places. From all of the forbidden spaces, this was probably the least socially attractive, repulsive even, marginalized in the generally positively assessed grey area, almost pushed into oblivion. Not being able to function on the surface, it was unwanted underground as well, which exacerbated the exclusion and the negative assessment weighing over it.

While discussing this subject, I would like to note, in addition, that some places, strategies and situations were not following this pattern and were functioning in a multiplied role. A hiding place did not have to have a "national identity" ascribed thereto; it would then serve not only its creators or discoverers, but people who needed it for a different reason and who were in a different situation. An example of such could be hiding places used by both Poles and Jews who happened to be in the same position, e.g. during bombings in September of 1939. The ruins of Warsaw destroyed in 1944 were a similar hiding place, where both Poles and Jews remained and were equally at risk of being killed by the Germans

245 See A. Bikont, My z Jedwabnego... [Us from Jedwabne] - The Story of Antonina Wyrzykowska.

246 J.T. Gross, Upiorna... [Ghastly...], p. 51. 
(order by general Smilo von Lüttwitz gave the Germans an excuse to kill every person hiding in Warsaw). I consider an example of a woodland bunker built by a "hermit" Moshe Aron Lajbcygier from Sulejów, later known as Florian Majew$\mathrm{ski}^{247}$, to be more interesting. When Moshe obtained Aryan papers, he joined the partisans, started moving around freely, spending nights in villages and not only in the bunker. Soon he became responsible for four Polish boys from Piotrków. Later there were more of them. From that moment forward, the bunker in which Moshe-Florian spent many solitary months became a camp of the partisans. Similarly, a house in Warsaw at 2 Brzozowa Street, where Monika and Anna Żeromski lived during the war with Pola Gojawiczyńska, had numerous types of hiding places inside. "The house at Brzozowa Street was truly a strange anthill. Because it had to entrances, from Brzozowa and Bugaj Streets, it was convenient in many situations. Something different would go on in all of the apartments on three floors. Secret complines, military points of contact, dens of escapees from prisons and camps, hiding Jews and tiny printing works for fake documents, everything was operating smoothly. [...] Sometimes somebody would get everything confused and would for example go to Pola Gojawiczyńska to buy light bulbs, which meant there was a meeting of conspirators upstairs"248.

\section{Part II. Individual perception of space}

They had to deal not only with fear, risk of losing their life, sense of extreme helplessness, but also with isolation, monotony of existence, need to be silent, weariness, exhaustion, hunger, cold, confined space, pain and physiological needs. Can we imagine what a person depending on others to take out the waste bucket, bring food and water feels? Can we surmise what does such a person feel when the rescuer "forgets" about him or is running late? That dreadful, ravaging boredom? What does a person crammed in a dugout with a few other people feels, haunted by his own entrails, nerves, vertebrae, joints, deprived of his own boundaries, fused together with his partners in misery?

Krzysztof Szwajca ${ }^{249}$

Using various theoretical angles of environmental psychology, shortly presented in the introduction, I shall attempt to analyze human experience in the space of a hiding place. First, we have to realize to what extent a situation of a hiding place was depriving people of their uniqueness. Defined space is such a powerful dimension of human life that it is virtually impossible not to submit to it. Henryk

247 F. Majewski, Pustelnik... [Hermit].

248 M. Żeromska, Wspomnień... [Memoirs...], p. 37.

249 K. Szwajca, Kłopotliwa "świętośćc [Troublesome "Sanctity"], "Midrasz" 2007, No. 1. 
Ogryzko-Wiewiórkowski wrote: "Ecological psychology research indicates that space has a stimulating effect on human behavior. People act in a similar manner in the same space conditions, regardless of their personality traits and life situation. In social life conditions there are places, which, thanks to their characteristics, enable or even provoke some behaviors, tolerate others, allow them, or exclude or even prohibit others" ${ }^{250}$. The author gives the simplest of examples: it is clear that nobody would dance in a museum or eat dinner in a church. And what about the space of a hiding place? An extreme space with exceptional influence? Above all, it controls people physically, as they have to adapt their actions to the dimensions of the hideout. They have to fit, adapt their bodies to the number of square centimeters given. After stating this fact, one has to perceive a hiding place primarily from the angle of human body. "Human being, irrespective of the epoch, is still a body, the boundaries of which separate the inner and outer spaces. Perceiving space from an anthropocentric perspective comes to mind naturally: space is understood as a basic and most primal cognitive and existential human category"251.

\section{Perception of space}

Perception is a human window to the world, a tool, or rather a process, allowing people to be connected with the outside environment, pick up and understand information, and to move in space ${ }^{252}$. There are a few theories explaining links between physical environment and the processes of perceiving it that take place in a human mind, e.g. theory of James J. Gibson's Gestalt school, which I am going to present below. Gibson stresses the role of physical qualities of an environment, placing the meaning on a stimulus, which affects human senses in the process of perception. An ecological analysis of physical human environment proposed by Gibson is interesting as well. It makes it possible to structure even the most complex spaces using three categories. Gibson claims that people experience environment as a medium, substance and space. The mediums are objects in liquid and gas states, so for people that would be water and air. The latter can be characterized

250 H. Ogryzko-Wiewiórkowski, Od proksemiki do socjometrii [From Proxemics to Sociometry], in: Przestrzeń we współczesnej nauce [Space in Modern Science], eds. W.A. Kamiński, G. Nowak, S. Symotiuk, Zamość 2003, p. 172. (K. Koffka, W. Köhler and M. Wertheimer), or "New Outlook" (E. Brunswik). The theory of perception by James is the most interesting from my point of view.

251 J. Gądecki, Architektura i tożsamość... [Architecture and Identity...], p. 13.

252 To understand physical and biological aspects of perception and senses - see R.L. Gregory, A.M. Colman (eds.), Sensation and Perception, London-New York 1995. 
in the following manner: it is transparent, transmits light, and makes it possible to see. It also transfers vibrations and pressure, making it possible to hear sounds. The air transfers the smells as well. People can move in a medium, and receiving the information it is transmitting makes it possible to effectively steer the movement process. By changing a place people also change their observational potential, as different sensorial stimuli are affecting them in each point of the medium. There are no clear borders between various kinds of gas and liquid mediums. Substances are solids, which obstruct the light, movement, and smells, and do not transmit vibrations that well. Substances can have miscellaneous properties, as Bańka listed while citing Gibson: "They vary in chemical composition, biochemical, physical, and behavioral activity. Some are edible, some are poisonous. Some are identifiable at close range, some, like aromatic ones, from a distance. Some are plastic, some elastic. Environmental substances are subject to chemical and structural changes. They can disappear, tarnish, rot, decompose, rust, and harden. Some substances undergo quick changes, some undergo slower ones, and some don not change at all. [...] As substances are formations, the components of which are usually connected in a complicated manner, they do not tend to become as homogeneous as mediums. Particular properties of substances give people various opportunities and create different obstacles"253. Surfaces make for boundaries between a medium and a substance, and their existence depends on the existence of a substance. Surfaces are places of direct absorption or reflection of light, they can be touched and they transmit vibrations from the substance to the medium as well. All substances have surfaces. Each surface is located in space, has a given tolerance to deformation and disintegration, specific texture, shape and some level of absorption and reflection of light. According to Gibson, a human living in an environment discovers its meanings as a sort of capacity (affordance) and uses it. For example, when looking at tree limbs, a child sees a ladder hidden therein, leading to the top and can make use of that discovery by climbing a tree.

Environmental psychology points to certain factors influencing perception of environment: attention and cognitive attitude. Attention is an internal pattern allowing people to choose stimuli from an infinite number of information generated by an environment and to concentrate on them. Large, intensive, unusually shaped, colored or sequenced objects attract attention. In monotonous systems, where there are no distinctive objects, the attention fades. Cognitive attitude means being prepared to receive particular information from an environment

253 A. Bańka, Społeczna psychologia... [Social Environmental Psychology], p. 64. 
even before they present themselves. A person's knowledge and experience, as well as the context and personal characteristics influence the perception. David C. McClelland and John W. Atkinson proved in the 1950s that the person's needs and desires influence the perception as well. People describe objects they need or desire as bigger than they really are. Perception is also shaped by a culture, in which a given person lives, and especially the language used to identify objects. This is the root of cultural differences in perceiving the same objects. Modern experimental research (e.g. Herman's experiment) indicates that the perception is connected with emotional states as well.

People experience space, i.e. also buildings, rooms, mostly via sensory experience. This observation was not always obvious, and entered the scientific discourse only in the middle of the $20^{\text {th }}$ century thanks to Steen Eiler Rasmussen. In the introduction to the Polish edition of Experiencing Architecture, a work first published in the source language in 1959, Ewa Kuryłowicz wrote: "The 'experience' of architecture signaled in the title is interpreted here according to an almost colloquial understanding of the word 'experience' - to experience something first hand, really, by touching. Whilst 'feeling' the architecture, i.e. only the emotional element, functioned as a conscious element of shaping its expression from the very beginning, legalizing its 'experience' had a lot more difficult road to come. The Ancients are at fault. The authors of the first prioritizations of human senses were putting some on a pedestal and ignoring the others. The later philosophers, who contributing to the shape of the contemporary idea of beauty - were emphasizing its intellectual, not sensory reception, and treated the senses as a source of lesser knowledge, are to blame here as well"254. The above statements concern the architecture of the time of peace, even talk about "beauty", completely inadequate when thinking about bunkers and dugouts. How can we adjust the thesis of sensory experience of every space to an analysis of the experience of a hiding place?

In hiding, the senses were not oriented toward aesthetic experience. Sensory experience in a hiding place is rather an attempt to survive in a strange, compulsory space, which is perceived by every nerve ending. People experience not only "the architecture", i.e. the construction of a hiding place itself, but also the whole physical environment of a hiding person. Particular design solutions in a hiding place, its physical parameters are determining the characteristics of that environment, which mean access to oxygen, light, presence of various smells, humidity,

254 E. Kuryłowicz, introduction to the Polish edition, in: S.E. Rasmussen, Odczuwanie architektury [Experiencing Architecture], Warsaw 1999. [For an English edition of the book, see S. E. Rasmussen, Experiencing Architecture, Cambridge, Mass 1982 translator's note]. 
temperature, noise. The accessibility of the world outside a hiding place and a way in which the information from the outside were reaching the people hiding are important as well.

\section{Sight}

Sight is the basic sense in the process of perceiving a space. James Gibson, when studying vision, systemized intuitive knowledge on the subject. One of his observations was that the sight primarily detects the arrangement of the surroundings, changes, sequences and movement. People perceive three dimensions of the environment thanks to the sight. They look at particular objects, and not "sensory qualities", so they see objects with specific characteristics, and not those characteristics in isolation from the object. There are laws conditioning perceiving an object: consistency of color brightness, consistency of shape, size, and location. Perceiving those characteristics can be distorted (e.g. by colored light), and the consistency limited, however, in general those laws cause the perceived world to be relatively unchanging, despite variability of conditions, and the objects create specific and meaningful systems in a human mind.

In the space of a hiding place, the sight was often not able to function as it would in normal surroundings. The first problem arose from a limited perspective (connected with confined space, but also with inability to change a position of observation, when stillness was required for safety reasons or was necessary due to the limited space). Consequently, the number of objects one could look at was limited. People could observe their companions, walls of the hiding place, sometimes look outside through a window (in exceptionally favorable cases), through a crack in a wall, etc.

There have also been instances when those scarce views were limited. Janusz Włodarczyk ${ }^{255}$ noticed that both excess and deficiency of light in a room can make life harder to a great extent. Inside hiding places people would more often face scarcity of light. After spending a long time in twilight or even complete darkness, people would get used to it. This was the case of the hiding place of Klara Falk and her son Michał in Miedzeszyn. They had a very primitive stash that was completely unfit to stay in for an extended period of time. A Polish woman they knew hid them in a shed, where they occupied a corner hidden behind a pile of firewood. When they were visited by Władka Meed (then Fajga Peltel), who was helping the hiding Jews, it turned out that they had not seen

255 J.A. Włodarczyk, Żyć znaczy mieszkać. Dom mieszkalny na granicy stuleci [To Live Is to Dwell. Residential Building on Turn of the Centuries], Tychy 2004. 
the sunlight for a long time. "First they asked me to close the door. The daylight was blinding them"256. When conditions were allowing for it, the hiding people were trying to deal with this problem by getting some light (Landsberg - electric, Goldstein - an oil lamp). The light made active ways of spending time, such as reading, possible, which was a blessing in a hiding place.

The dichotomy of light and darkness, highly saturated with cultural meanings, was often provoking reflections on the exceptional situation of a hiding place. Włodarczyk defines the basis for such deliberations: "The stereotype of conviction of the undisputed benefits of light is still present in our subconscious. There is a myth of the good light and bad darkness" ${ }^{257}$. Reflections on the subject were e.g. conjured by Goldstein, who would leave the bunker at night to see the city, but instinctively hide from headlights: "I used to think then that here, in the ruins of Warsaw, it is the opposite - the brightness can attract wicked spirits to me, manifested by Nazi thugs, but the darkness envelops me and delivers from evil"258.

\section{Hearing}

When it is impossible to make the full use of the sense most basic to a human, the vision, the function of this sense is partially taken over by other senses. The sense of hearing seems to be the most important of them. It allowed for having conversations, feeling other people's presence, and in a case of solitary hiding places - talking to oneself to at least occasionally hear human voice. There are also unpleasant feelings connected with this sense - for example being forced to hear other people argue, listening to screams and moans of sick or deranged people, and fear, that accompanies a sound inviting disaster despite an order to keep quiet because of the danger. "When I write about knocking, I am thinking about the world of sounds, in which the Jews lived in the bleak seasons. One can say that there were sound signals which were characteristic for the executioners. I do not even mean the slamming of hobnailed boots on the pavement, heralding that the troops are coming to the ghetto to chase the people to the Umschlagplatz, the slamming as sinister, as the marching songs they used to sing. I am thinking about the sounds that seem neutral as such and are not connected with anything in particular in normal times, they are not associated with fear. When I and Mother were hiding in the countryside, a roar of an approaching car would cause a great

256 W. Meed, Po obu stronach muru. Wspomnienia $z$ warszawskiego getta [On Both Sides of the Wall. Memoirs from the Warsaw Ghetto], Warsaw 2003, p. 236.

257 J.A. Włodarczyk, Żyć znaczy mieszkać... [To Live...], p. 151.

258 C.I. Goldstein, Bunkier... [Bunker], p. 178. 
fear, which is hard to imagine. In a way, it meant just one thing, the passing cars were rare, only Germans had them. When a car appeared on a puny back road, it was never a good sign. The sounds of a car could have been beacons of death"259.

First of all, the hearing was transferring the information from the outsider. There were not many hiding places muffled to such an extent that no sounds from the outside world would reach them. Those were both warnings about danger (sounds of people approaching) ${ }^{260}$, and neutral information which were slightly counteracting the barrier separating the world from a hiding place. A bulk of such information would originate in an apartment of the hosts in case of hiding places "under the same roof". Those were not only news about what was going on in the apartment. The aural stimuli would also transfer the moods and emotions. Interpretation of the sounds from the outside could have exacerbated the feeling of isolation and loneliness, or, alternatively, make the hiding people forget about their fate for a while.

Here are two twin situations, in which a sound of a party coming through a wall or from above causes extremely diverse feelings, depending on the behavior of the hosts. The first situation is described by Menachem Katz (a hiding place under the floor, Christmas 1943). The hosts gave the hiding people some holiday treats and thanks to that friendly gesture and the sounds, the people below were in a way taking part in the celebration: "The party in the house above started with the guests stomping their feet, the sound of the chairs being pulled, and kids running about. The noises were fading as the guests sat by the table and started singing carols. Through a rock slightly pushed to the side we could sometimes hear the songs of the dressed-up carolers walking door to door. The bunch of us in a hiding place at Kmiećs, stuffed after a Christmas Eve feast and with slightly lifted spirits, slept lightly with the melodies coming from afar"261. A completely different situation happened to the family of Marian Berland, who, in case of

259 M. Głowiński, Czarne sezony [Black Seasons], Warsaw 2002, p. 87.

260 Stella Fidelseid described voices and footsteps of German soldiers, "Kwartalnik Historii Żydów" [Jewish History Quarterly] 2003, No. 2(206). She was hiding in a bunker during Warsaw Ghetto Uprising: "In silent tension, huddled together, we were listening to the footsteps of thugs walking above our heads. We clearly heard them shouting, talking. Suddenly we hear shuffling from the side of the yard, hollow bangs against the pavement, rocks being thrown. God, don't let them find us. [...] Hours are dragging. [...] We can still hear the Germans searching the yard. We finally hear steady footsteps underneath, march off, shouts and voices trail off, it's quiet, they are probably gone".

261 M. Katz, Na ścieżkach nadziei [On Paths of Hope], Warsaw 2003, p. 192. 
emergency, hid behind a wall that was put up in a room. An opportunity to use the hiding place presented itself on Easter of 1944, when the hosts, Krzeczkowski family, invited a friend. "She won't stay long, a few hours at best [...]. In the meantime, we'll stay in the stash"262. Sadly, the ill-fated visit stretched to two days, and so the people hiding had to spend a lot more time than expected in a hiding place not suited for that purpose.

The aural sensations repeated multiple times in the same way were making up for a constant of sorts, a permanent arrangement of data allowing figuring out the environment despite the limited perception. A change in some element in this arrangement would cause disorientation. Landsberg describes such a situation. When the snow fell and started muffling people's footsteps, which were perfectly audible before and which were giving a sense of being a part of the outside life, the residents of an underground hiding place felt cut off from the world.

\section{Smell}

The sense of smell is also very important in a hiding place. Sometimes it is the only sense that could be fully utilized when faced with limited potential for using eyesight, moving and lack of aural sensations. Wilhelm Dichter reminisced: "I have been sheltered for a few years during the occupation - I was five-nine years old - in Polish or Ukrainian homes: under a bed, in the attic or in a niche dug in a well. I would sit there and wonder when they would come and get me. I lived on my memory. It was dark and only the smell was carrying the signals from the world. This way - if I may say so - I have learnt many interesting smells. It was like regressing to an animalistic state - the world of creatures who know no grammar or language, who are additionally alone, since even a dog will always find another dog to sniff around the world together"263.

In a hiding place, where it is hard to stay hygienic, an overall combination of smells is unbearable. It is the smell of unwashed bodies, sometimes rotting, festering wounds, bucket with excrements, dirty clothes. Sometimes there were different, unusual smells. Menachem Katz ${ }^{264}$ described a conflict that arose in a collective hiding place, when one of the men staying there wanted to smoke a cigarette. On the one hand, everybody thought about the safety precautions, as somebody could see the smoke coming out of the vent. On the other hand, the

262 M. Berland, Dni długie jak wieki [Days Like Centuries], Warsaw 1992, p. 383.

263 K. Janowska, P. Mucharski, Rozmowy na nowy wiek [Conversations for the New Century], vol. 1, Cracow 2001, p. 71.

264 M. Katz, Na ścieżkach... [On Paths...]. 
smoke in a stuffy place would additionally decrease the level of oxygen available. Residents of a hiding place at 64 Targowa Street in Warsaw have created an almost humorous situation, when they had decided to eradicate the fleas that were bugging them. Sadly, the mixture of ammonia and chlorine they have prepared for that purpose became a source of fumes so suffocating, that they were forced to open a window and ventilate the room. Leon Guz commented on it jokingly: "I think we were close to falling victims of this disinfection"265.

Of course, one has to acknowledge that the people hiding were not condemned only to foul and repulsive smells. Sometimes the outside world would manifest itself in a pleasant manner. For example, the nature in May got inside the walls of Maria Koper's hiding place: "And so the darling May came. But it is not for me, for I am stripped of everything, all is blooming in exaltation and smells, the lilacs, the pansies, the fruit trees, basically the world is as beautiful as it is in May"266. A tomato turned out to be a wonderful gift for Stella Fidelseid. It came to the bunker with bountiful smells of freedom: "Mojsze gave me a small tomato. I sniffed it from every side, it smelled like the sun and the air"267. In turn, a severe, prolonged hunger could cause gustatory and olfactory hallucinations, causing the people to reminisce about delightful flavors and smells, as was the case of Lila Chuwis-Thau: "When we meet other hiding people, the conversation always winds up being about food. Usually somebody starts with 'Remember how the table was set before the war? And how each dinner had a few courses?' And suddenly you see the baked geese and other delicacies. You can smell the enticing smell of the meat being cooked"268.

The sense of smell is associated with breathing. One can go without eating for some time, without movement, for a short time - without water, but without air people die in a matter of minutes. The Germans knew about it, and that is why the gas pumped into the hiding places during liquidations of the ghettos (the socalled "smoking out" of a hiding place) was such a formidable weapon. Allowing breathing is the most basic function that a space earmarked for a hiding place should fulfill. It is not that easy, as huddling human bodies use up the oxygen, release carbon dioxide and water vapor. After a few hours, the humidity rises in a locked up hiding place. Lack of air and a feeling of suffocation cause distress and later panic. Hiding places from which one can get out to get some air are much easier to bear. This experience is repeated in many descriptions. I shall cite

265 L. Guz, Targowa 64... [64 Targowa Street], p. 158.

266 AYV, 033/334, Testimony of Maria Koper.

267 S. Fidelseid, Pozostałam w gruzach... [I have stayed in the rubble...]

268 L. Chuwis-Thau, A jeśli Cię zapomnę [And if I forget you], Warsaw 2002, pp. 66-67. 
Leokadia Silverstein here: "It was so stuffy that you could see the air. We were breathing in each other's effluences. The air was dense from too much of carbon dioxide - no wonder we were all having headaches. We felt we were suffocating [...] we just couldn't stay there anymore. We got out of there like if it was a bathhouse. What a delight it was to inhale fresh air again!"269.

\section{Touch}

I think that from the point of view of the space of a hiding place, the touch is the most important of senses. That is why I am going to devote the majority of these deliberations to that sense. As Jolanta Brach-Czaina noted ${ }^{270}$, it is hard to write about the touch. Nevertheless, when trying to describe experiencing space of a hiding place by people, it has to be done, even if we have to take the long way. For the touch explains the existence of a human being. "Thanks to the touch our presence is not manifested in the void, but against another, close reality. [...] Touching means the most direct communion"271. People experiencing a hiding place with the sense of touch are condemned to a whole gamut of sensations from which there's no escape. The touch told them in the most detail how inevitable and limited was the spatial situation in which their bodies happened to be. Among those sensations, the majority was negative. Hiding places were often connected with extremely bad conditions. People huddled in a dugout, a bunker, shed, barn, pig pen, on a small space, were forced to have direct contact with matter that they would probably avoid in a "normal" situation. "The world touches us when we touch it", said Brach-Czaina ${ }^{272}$. What constituted that world in the vilest hiding places (in this description I am leaving out the "luxurious" hiding places at homes, close to regular conditions, in which the surfaces in contact with human body were close to everyday experiences furniture, clean bedding, carpet, floor)? Its substance could have been the walls damp from condensed breaths (or worse - covered with mold because of that dampness, like the walls in Landsberg's and Rudy's hiding places. Soil filled with worms and roots, clay and mud. Rotten and carious boards. Excrements, one's own or somebody else's. "The cubbyhole was located in a home they live in, at Kosynierska Street (next to Czysta). They have spent two weeks hiding there in horrible conditions. They had nowhere and no way to go out to the toilet, so

269 L. Silverstein, Tak właśnie było... [That's What Happened], pp. 155-156.

270 J. Brach-Czaina, Błony umysłu [Mind Membranes], Warsaw 2003.

271 Ibid., pp. 68-71.

272 Ibid., p. 59. 
they were soiling themselves" - says Dina Wajnsztajn about her hiding place in Białystok ${ }^{273}$. Various objects, which were no longer useful, were accompanying the residents of attics and basements in their "afterlife": old furniture, rags, potatoes with very peculiar scent, hay, splinter-filled wood, and messy coal. The surfaces were dusty, slimy, wet. The list goes on. The objects, surfaces, especially in "space-effective" hiding places, seem to dominate, push onto the human body, which is now all made out of touch, it has nowhere to pull back, no way to take a break from the physical contact with the tissue of a hiding place. In majority of cases the body has to adapt to the objects, not the other way around. Landsberg wrote down: "I'm still sitting on lime in a barrel. Only my legs and the head are sticking out. The barrel is oval, it used to stand in a shop and there used to be ice-cream in it. [...] I wake up with pain in my back and under my knees - sharp edges of the have barrel sunk into my body" ${ }^{274}$. Gail Hersz, who was hiding in Drohiczyn, wrote about "struggling" with potatoes: "My hideout was under a basement floor. There was a tunnel leading there. The basement was filled with potatoes, which they were generously giving out before the liquidation. I have managed to move back the potatoes with great difficulties. I have pushed my legs into the tunnel and covered myself again with my hands"275. Hay, straw - those were other aggressive substances filling up the hiding places in the countryside. Dwojra Frymet reported: "I once hid in a barn, so they wouldn't find me. I have almost poked my eyes out with blades of straw"276. "There were no windows in the basement and it was full of straw" - Etka Żółtak mentioned ${ }^{277}$. Rywka Wajnberg talked about hiding places at forest ranger Mikulski’s in Duża Wola village: "The ranger made a cubby in a barn behind the cow trough, it was covered with that trough and manure. The children would climb into the cubby and cover themselves with hay. [...] Mikulski made a hiding place under the hay for the three remaining Jews" ${ }^{\prime 278}$. One can try to imagine the pervasive hay, like a vegetal force of nature, which may smell pleasantly right after being harvested, but later, overflowing with dust and mites, it appears to be choking and viciously biting the people trapped inside it. This sensation is accompanied by the temperature but not only the air, but also the objects. When a hiding place is located in the attic, the tin warmed up on a hot day burns the body. In the winter, the damp walls

\footnotetext{
273 AJHI, 301/1472, Testimony of Dina Wajnsztajn.

274 AYV, 033/1099, Journal of M. Landsberg.

275 AJHI, 301/6640, Testimony of Hersz Gail.

276 D. Frymet, Relacja... [Testimony...], p. 608.

277 AJHI, 301/545, Testimony of Etka Żółtak.

278 AJHI, 301/1437 I, Testimony of Rywka Wajnberg.
} 
become freezing cold, and when they are also leaking (as they were e.g. in Maria Koper's hiding place), the cold becomes unbearable.

Clothes, which usually protect human body from constant direct contact with the world, were no longer fulfilling their function in many hiding places. What was it like in woodland hiding places, where the escapees had to survive on a finite number of items they took to the forest with them or bartered with villages, which did not have many items either? Aleksandra Bańkowska wrote: "The lack of clothing items and the clothes and shoes quickly getting worn out was a big problem. People were selling every last bit of clothing to get food. Shoes, clothes and even undergarments were often stolen from the Jews wandering the forests. Lack of clothing was especially affecting the people who slept in the open air. Residents of dugouts were exchanging clothes, giving them to people going out to the village to get food. Sometimes people were able to get (or buy, but it happened less often due to not having much money) clothes from the local farmers, especially from permanent guardians. It would seem, at least in some cases, that this help was significant. One farmer even donated leather coats. Maria Mikułdowa gave the people she was caring for everything from her late mother's closet. People were also trying to get by differently: if they were able to obtain fabrics they needed, they would sew clothes and knit sweaters and socks in their hiding places. Fejga Frejnkman reported that some people dealt with the lack of shoes thanks to homemade clogs and footwraps. However, in many cases lack of shoes could not stop people from going out to get food, which ended badly - with frostbites.

Clothes would get worn out quickly due to dampness of dugouts or from getting wet in the rain, from walking in a dense forest. Another important reason of their ephemeral nature was using various methods to get rid of lice. "Lice were present in a dugout from the very beginning. It was inevitable when a few people were crammed together in a confined space. Fighting them was necessary, but hopeless"279. The author wrote about problems with hygiene - bathing and laundry were a rare privilege. Those observations can be extended to many other hiding places, not only the ones in forests. The comfort of the sense of touch was the last thing people considered. In the hierarchy of needs the cleanliness and fabrics pleasant to the touch were far behind the needs of security and satisfying the hunger. Although, as the testimonies indicate, one's own unwashed body wrapped in dirty rags and constantly irritated by touching unpleasant surfaces made for an intolerable torment. This is why some authors of the accounts attentively mention a seemingly unimportant detail such as an even symbolic barrier between

279 A. Bańkowska, Las jako miejsce... [Forest as a Place...], pp. 52-53. 
"me" and "the world" offering an illusion of comfort. Israel Herc, who was hiding near Garwolin, recalls one of the hiding places: "The hideout was in the attic, there were 6 of us there. We had bed linens there"280. Menachem Katz and Florian Majewski also took care of putting clean sheets on mattresses and in lying areas, when they were searching for a place to hide. Katz talked at length about the issue of bed linen and concluded: "The conditions seamed bearable from the perspective of lying on a clean sheet"281. Majewski stole sheets as an article indispensable in his "household" from a farmer from Siucice. In the new bunker, he carefully prepared the "bed": "I have covered the lying area with leaves and moss to serve as a mattress. I have thrown a linen sheet on it. I have covered myself with another piece of cloth and slept comfortably, happy about my accomplishment"282.

It sometimes happened that the unpleasant, yet harmless touch of the matter would transform into its literal offensive - e.g. a crumbling ceiling could have attacked the inhabitants of a hiding place. Katz described such a situation: "The heat of the fire and our bodies was melting the frozen soil of the bunker walls further and further, until it became a soggy mud. Just before the dawn the silence of the night was shattered by a terrified scream coming out of the corner where Rywka slept. [...] At the exact same moment, the roof shook. We could hear the rattle of the land sliding and the creak of the beams grinding against the wall next to the fire. [...] - I'm not dreaming, the soil covered my legs! [..] The roof fell on my legs, look, you can see the sky, and my left leg is trapped. Help, help me!"283. Another massive attack of the matter could come from a flood in a hiding place, just like the one Landsberg survived: "Today an incredible thing happened, we almost died. We were sleeping during the day, as we used to do, since we were getting out to the chest at nights, and an awful slosh woke us up at 1.00 PM. Just when I turned on the light I understood that water was pouring out of the chest. Rudy grabbed a trowel and a light bulb and went to the dig, but a wave suddenly crashed in and threw him back to the locker. At the same time the water drowned the bulb and the wire, and a current with $220 \mathrm{~V}$ tossed him against the wall. The locker started literally filling up with water. Rudy was pale as death and yelled: 'We're dead!'. The falling water was sloshing so much that we were barely able to hear one another. I called out to R. to try and open a dirt box that was covering the entrance to the basement. Rudy dived in, chocked up on the water, got back up and calling out: 'I can't'. I shouted: 'Try again - that's our

280 AJHI, 301/1496, Testimony of Izrael Herc.

281 M. Katz, Na ścieżkach... [On Paths of Hope], p. 127.

282 F. Majewski, Pustelnik... [Hermit], p. 68.

283 M. Katz, Na ścieżkach... [On Paths of Hope], pp. 161-162. 
only hope'. Rudy dived again. Water's pouring. I'm trying to push back the floating bulb, which is still on. Water's up to our necks, Rudy's not back, it's high time! [...] If the hatch hadn't been opened, the water would have filled the locker up to the ceiling a long time ago. [...] We're waist-deep in water. Everything is floating in the basement. [...] Our place is flooded and we don't know if it's ever going to be fit to use. [...] a cloud burst"284.

The second aspect of the touch in a hiding place is the presence of other people, who, at that point, are treated like additional objects - they are also unpleasant to the body, hot, not budging, and constricting. I shall later discuss overcrowding and its psychological and physical consequences. Here, I am only presenting one short quote showing the hardship of being forced to touch strangers. Stella Fidelseid ${ }^{285}$ wrote: "It's really hard to take it in a hideout. It's cramped, stuffy, dark. People are so tired that they are leaning on one another. Bickering, hissing".

Ever-present alive bodies are hard to put up with. And the dead bodies? Leokadia Silverstein wrote: "We were struck by a morbid stench. At some point, I have stepped on something mushy"286. It was a corpse that one had to simply step over and keep going. All was well when there was a place to go and people did not have to touch corpses for hours on end. (I write more on dead bodies in hiding places in Chapter 3).

Yet, sometimes the physical presence of the bodies of other people was salutary - for example when the body of the companion was the only available heat source. Menachem Katz talked about a cold October night he spent in a forest, in thickness of the woods, before the bunker was built: "We lay down, clinging to one another, on bedding made of dry leaves, covered with clothes and rags we had. [...] Despite the cold, snuggling and warming each other up, we survived the first night in the forest easier than we suspected"287. The touch of another human being was also helping in the most terrifying moments - Stella Fidelseid described how the people crowding in a hiding place, fed up with the presence of others, were clinging to each other when they heard the Germans' footsteps upstairs. The mothers would tightly hold their children, and Stella herself would clasp "tightly to Ryśka Wi[e]nerowa". In a situation like that the touch is an instinctive human defense, the deepest human need.

284 AYV, 033/1099, Journal of M. Landsberg.

285 S. Fidelseid, Pozostałam $w$ gruzach... [I have stayed in the rubble...].

286 L. Silverstein, Tak właśnie było... [That's...], p. 177.

287 M. Katz, Na ścieżkach... [On Paths of Hope], p. 145. 


\section{Personal space and environmental stress}

Personal space is a notion consistently present in environmental psychology. There are two types of personal space:

- Robert Sommer's definition (based on clinical observations) stresses the defensive function. A personal space is an unchangeable "air bubble" with fixed dimensions that nobody can cross;

- in Heini Hediger's definition (animal observations: a distance of combat or escape appear depending on the proximity to another animal), and later in Hall's - there is a linear space, variable interpersonal distance.

Personal space is perceived by touch, smell, and hearing. A human being is also able to perceive space by sensory proprioception. Interpersonal distance varies for every life function. Categories of density and crowding are closely connected with the notion of personal space. Those categories were used for example by Daniel Stokols and Allan W. Wicker (the latter is an author of a concept of overmanning, which is useful in social sciences and which means a spatial situation where there is more people than there are available social roles).

Density is an objective accumulation of people on a given space and crowding is its subjective reception. It causes a sense of stress - the available space is smaller than desired. A predisposing factor conditioning the feeling of crowding is a set of internalized cultural norms (the sense of interpersonal distance looks different e.g. for a northern European and for an Arab ${ }^{288}$. Another factor is the previous experience of density - for somebody who grew up in one room with a few siblings, it is easier to withstand the tightness of a hiding place than it is for a pre-war resident of their own room. The third factor is the motivation. When people have to save their own lives, the instinct for self-preservation is stronger than a feeling of discomfort. As a stay in a hiding place is prolonged, the crowding of the space becomes peskier. External characteristics of the space conditioning the feeling of crowding are the spatial structure of the system of behavior (i.e. the construction of a hiding place) and its organization. When the community of hiding place's residents is able to work out functional rules of making use of the small space, the feeling of overcrowding becomes less trying. That is also the case when the stay in a hiding place is regulated by some temporal rhythm - for example when a group of people spending whole days cramped in a bunker can go out at nights: "The evening came. It was already completely dark outside, as

288 See E.T. Hall, The Hidden Dimension, New York 1990. 
seen through a crack. People in the bunker got invigorated. They were getting up to stretch their tired limbs"289.

In environmental psychology, the conditions of crowding are illustrated by Daniel Stokols's model ${ }^{290}$. According to this model, the crowding is caused by an overload of stimuli, limitation of freedom of choice of behavior and scarcity of resources in relation to the number of people wanting to have an access to them. Hence the crowding means too many stimuli generated by other people (their presence, sounds, heat, touch); an imperative of forcibly staying with them in a confined space, in a situation where there is no escaping or remedying that state; and, of course, the scarcity of free space. In his animal studies John Calhoun ${ }^{291}$ described a concept used henceforth in environmental psychology to analyze people's behavior in harsh spatial conditions: a behavioral sink. The specimens crowd together in a pre-learned fashion, despite having enough room, creating a secondary density, and, as a result, some react in hyperactivity and some in passivity when faced with difficult conditions. Crowding results in nullifying personal space, which is vital for proper functioning of a human being. Environmental psychology calls the feelings of a person in such a situation a feeling of losing control over access to oneself. When staying in a crowded place, people are constantly exposed to others, even if they do not want it. Therefore, they no longer have their personal space at their disposal.

All the above-mentioned factors could, of course, arise only in collective hiding places.

Aside from fear and tension caused by traumatic experiences and constant danger, people hiding would also exhibit environmental stress connected with a place in which they found themselves. Augustyn Bańka ${ }^{292}$ distinguishes a stress caused by the parameter of the space and connected with presence of other people. I shall shortly address two models of environmental stress. The first one is the physiological model. Hans Selye describes it as a "general adaptation syndrome". It is a universal reaction of an organism to environmental distractions, i.e. all the elements of an environment which are in any way irritating and uncomfortable to a person. Those elements are called the stressors. First the organism goes

289 S. Fidelseid, Pozostałam w gruzach... [I have stayed in the rubble...].

290 D. Stokols, The Experience of Crowding in Primary and Secondary Environments, "Environment and Behavior" 1976.

291 J. Calhoun, Population Density and Social Pathology, "Scientific American" 1962, No. 206.

292 A. Bańka, Społeczna psychologia środowiskowa [Social Environmental Psychology], Warsaw 2002. 
through a phase of adaptation, trying to reduce the stress to a tolerable level. When it is unsuccessful despite the efforts, the organism goes into an exhaustion phase, which, in extreme cases, results in death. There are only two solutions in a state of severe environmental stress - escaping a situation causing the stress or adapting to it. When no solution proves effective, the organism reacts in a loss of physical and mental health. The second model is connected with human psychology. Since people are capable of an assessment of situations, they are able to handle stress on levels other than physiological. Cognitive processes and judgments are moderating body's response to the environmental factors. People owe the ability to survive even in the harshest environmental conditions to the defensive mechanisms of the mind.

Let us briefly list the environmental parameters that can act as stressors (majority of them was mentioned in the subsection on perception). Thus, those are lighting (to little or too much, poor quality), noise (or vexing silence), trembles and vibrations, temperature (ranging from scorching to freezing). All those factors were, with various intensity, present in the hiding places, despite the fact that, when choosing a place, the people were often trying to reduce the risk to the minimum. Protecting oneself from extreme temperatures was one of the most popular measures (lining the walls of a dugout with wood, finding covers, other insulation methods), along with installing sources of light. However, it would often happen that, especially in impromptu hiding places, which were not prepared beforehand, those stressors, especially in case of long-term exposure, were taking their toll. The most extreme form of environmental stress would even lead to insanity.

I shall mention another element causing unpleasant sensations - lack of orientation in space. A hideout, as a place connected with experiencing severe stress, a place with which a person does not identify, especially if it is changed frequently, causes a peculiar state of mind - people can forget where they really are. This feeling can be compared to the situation of a morning confusion we know from everyday life. Stella Fidelseid said: "It was completely dark when I woke up. At first, I couldn't recognize where I was, the candles were out, I could only hear the sighs of the sleeping" ${ }^{293}$. I have not, however, came across any testimony, in which the author would talk about getting lost in a hiding place (presumably due to the small size of a majority of the shelters) or losing a hiding place itself after getting out of it. One could imagine that such situations could have happened in a forests or city rubble, where a hiding place would blend in with the homogeneous labyrinth-like surroundings.

293 S. Fidelseid, Pozostałam w gruzach... [I have stayed in the rubble...]. 
Another important parameter of space generating stress would be its physical size. A person trapped in one place feels discomfort, stillness, tightness, claustrophobia. Hiding places present the whole spectrum of sizes. At one end, there are extremely tight stashes, where it was impossible to move at all (those mostly include temporary hiding places or "hideouts within hideouts"). Those could include a closet, cubbyhole, double wall. Later there are hiding places where people were at least able to change positions from sitting to recumbent, or at least have space for some limited movement; however, the dimensions of such hiding places would usually fall within one cube meter. Landsberg and Rudy, for ex ample, had such a hiding place: "I'm sitting in a den shaped like a cuboid, about 1 meter high, 1 meter wide and 1.6 meter long"294. Next, we can list hiding places in which it was possible to comfortably stand up, walk a few steps, regular-sized rooms or attics, or even great spaces of abandoned tenements and labyrinths of basements. There were also more complex options, like a warehouse, where Baruch Milch was hiding during an action in Tłuste: it was, as he said, "huge, 40 meters long, 10 meters wide". However, Milch was looking for a secluded little place to hide within this great area - as a result he's spent over 24 hours in an attic corner, motionless and covered with hay.

\section{Body in a hiding place}

The space with unnatural parameters has a powerful effect on the psyche. People in confinement experience ambivalent feelings. Of course, they want to get out, feel that there are other free meters of floors, ground, and pavement, and not only the half a square meter they occupy. They want to feel that there are other rooms than this tight and uncomfortable body case. Perhaps, they dream of solitude, intimacy, wish for walls to appear inside the hiding place to protect them against enemies and to protect them against the intrusive presence of the neighbors. In a normal home, there are two types of walls. Some separate the inside from the outside, the world from home. They let us feel safe. There are also walls determining the internal order of the rooms, separating their functions, sorting them. They allow for another level of separation: an inertial one. We can close the doors to a room, hide in a kitchen or on a staircase, or lock ourselves up in a bathroom. Just to be alone for a short while, to remind oneself about our physical distinctness. It is not a luxury, even residents of tiny apartments can do it. Additionally, the number of the housemates changes throughout the day. They go to work, school, shopping, for a walk, they vacate the piece of space they

294 AYV, 033/1099, Journal of M. Landsberg. 
were previously occupying. In the free space obtained in such a manner we have a chance to stretch mentally.

Such a situation could rarely occur in a hiding place. There is a forced stillness. People have to be quiet, they cannot move about. Even if a hiding place has inner walls, everybody gets a permanent place. The luxury of solitude is unknown. There is no choice. We are exposed to a gaze of numerous people in every nook and cranny.

So, if there is a chance to go out, even just for a little bit, people eagerly jump at it to be back shortly. A connection is established between people who spend time together. Perhaps, it is easier to stay and be comforted by the human presence than to look for a better place alone.

We have to note that the biological imperative is the most basic existential experience in the conditions of a hiding place. Alicja Rokuszewska-Pawełek made such an observation when analyzing the trajectory of the fate of Poles after the Second World War. When describing the experience of a concentration camp, she noted that aside from the physical violence and constant danger, the prisoners were severely experiencing "the inability to satisfy the basic biological needs and their simultaneous persistence"295. The author also noted that the prisoners were then realizing the power of biology, which was stronger than their own will and which was stripping them from being able to decide for themselves.

That experience, familiar to the residents of the hiding places as well, in their case closely related to the available space and constant danger, was causing a specific attitude toward their own body to be formed. As it was imperative to hide, the body was treated like an object. It suddenly becomes the most important, it is constantly in the center of attention, the majority of actions concentrate around its needs and risks it generates. A hiding place requires discipline and self-control. "As every human abode, our room also had its own daily rhythm, its own individual life. From 6 AM to 4 PM the life froze in there. The hosts where at work then, so nobody was there, since there couldn't be. If you have to exist in such a room, you have to in a way renounce your body and your physiological functions. Then you have to become like a motionless object. In that first 9-hour daily phase, our hands, legs and internal organs would freeze. Only the brain and the heart would go on"296. It was a mixed type of a hiding place - "intermittent", where the people hiding could lead a relatively "normal" life compared to those who were not allowed to live. Only during the hours when the apartment

295 A. Rokuszewska-Pawełek, Chaos i przymus... [Chaos and Compulsion...], p. 185.

296 J. Aleksandrowicz, Kartki z dziennika... [Pages...], p. 54. 
was just an apartment, the life of the people hiding could freely mix with the activities of those who were legally living there. It was possible as long it was undetected. However, there were continuous hidings, where people could not afford moving freely even for a second. Stillness of the body, similar to death, yet with retention of residual life, brings coma to mind. "A coma is a horrible cage. The extent of suffering of somebody in a coma, who retained or gained consciousness, is unimaginable. All the information is getting in, but nothing will come out. A person is trapped, captured by own body, suddenly rebellious and unfamiliar. The pain is unbearable"297. A person hiding, aware of the lost opportunities, everything, that he or she cannot do, is also in such torment. That person's body becomes that "self", a burden reduced to its physical size. The act of "hiding oneself" can be seen as a separation of a mind and a body. The mind has to see the body as a package that has to be stored. The mind cannot count on the cooperation with the package - it cannot be compressed, its dimensions cannot be changed. It is hard to control; it can play a dangerous prank. Despite being an object, it has its biological needs, so aside from hiding it from sight, hearing and smell, one has to take care of it, even at very minimum (air, food, water, temperature, excretion). In a hiding place, a human being remains as an integrated whole, but also as his or her own enemy. The person has to save something that is not cooperating, which makes for harsh conditions.

It is hard to say how the residents of hiding places felt about their bodies. The situation was probably dynamic, varying in time and dependent on various circumstances. I will, however, attempt to list a few possible ways of perceiving a body in a hiding place:

- something to care about - it has to be hidden;

- a nuisance - it has its demands, dimensions, and needs;

- a threat - it generates sounds, heat, noises, so it can be a giveaway;

- a currency - people would often pay with sex for help;

- a burden and source of suffering - illness in a hiding place;

- a prison - imperative to hide the body, which cannot be "dressed up" as a non-Jewish. A body is to blame for everything, this is why the texts are full of dreams of e.g. becoming an animal, who is not threatened by anybody and can go wherever it pleases;

297 E. Błaszczyk, K. Strączek, Wejść tam nie można [You Can’t Go in There], Cracow 2005, pp. $180-181$. 
- a blessing - the idea of Kiddush Ha-hayyim, the sanctification of life, i.e. protecting the body, the gift from God, at all costs, is still present in the hiding places;

- a helper - when it is in a working condition, healthy, not making any trouble, strong, then people could e.g. manage to remodel of a hiding place or escape; the stronger person can take charge in a group;

- a problem - when the natural issues connected with physicality arise. Sex, pregnancy, birth, death - all of that would generate unimaginable problems and practical complications in conditions of a hiding place.

All those limitations are basically impossible to understand for people who have never gone through something like this. To illustrate a profound astonishment of such a complete and prolonged objectification of a body, I shall cite a fragment of an account of the aforementioned Helena Grabarek. She was quoting a conversation between Abram Grinbaum, who was hiding at her farm for three years and her son-in-law, a "Varsovian", which they had when they could already see Russian tanks heralding the liberation. "Who's that, that man. Ya clean [sic!] here? Well, yeah, it's three years since I'ma here, ya been here just five months, youze been here just a year. That's it, right. How could ya'll been here, I've been here the whole year and haven't seen ya ever. Ya were not a piece of wood, have ya, to lay ya down and let ya stay there, I was getting eat three times a day, only our housekeep could keep somthin' like that. Oh, yeah, true. So weird I would never weirded [sic!] ever, such a secret in our home"298. The metaphor of a "piece of wood" used by one of the speakers is accurate and cruel in its simplicity. (The fragment demonstrates a perfect secrecy of the hiding place, since even the housemates kept in the dark had no idea about its existence).

\section{Summary}

This chapter was fully dedicated to social and individual perception of a hiding place. In the beginning, I was trying to establish the place in the structure of social space which was taken up by this new, unusual construct of a Jewish shelter. How its existence is received by individual social actors? That analysis led me to conclude that a Jewish hiding place was isolated and marginalized on the map of underground Poland. It can be therefore described as an unwanted, dangerous, cursed space. The subsequent part of the chapter presents deliberations on the space of a hiding place from another point of view.

298 AJHI 301/5149, Testimony of Helena Grabarek. 
Thus, I describe sensory experiences of the hiding people, troubles of a body trapped in a cramped, uncomfortable place, often filled with other bodies. A thought about objectification, and at the same time of absolute domination of a body in a hiding place, brings me to the Chapter 3. Not deviating from the perspective of the authors of the testimonies, so an "inside" look, I write about senses and meanings ascribed to hiding places by the authors of testimonies. The metaphors recurring in the texts allow us to notice other characteristics of hiding places and to reflect on to what extent the way in which the people hiding see the place they are in is shaping their sense of identity. 



\section{Meanings in a space of a hiding place}

A meaning is a key concept in an understanding of space I find relevant. The classical approach of Yi-Fu Tuan gives us an opposition of space and place as a tool for analysis. The tension between the untamed, wide space and a place, which is labeled and inhabited by human beings, is used as a category explaining the notions, such as a phenomenon of local patriotism, feeling nostalgic for the identity of childhood places, anthropology of a home.

Dictionary of psychology of architecture gives the following definition of a place: "Place (lieu, Ort) - a result of relations between physical attributes of a given space and activities and concepts (notions) connected with it [...]. A place is always limited, man-made and adapted to specific intentions [...]. A place is a basic element of human existential space [... $]^{299}$. Phenomenology of space by Noeberg-Schulz is based on an otherwise known concept of genius loci, "protective spirit of a place". While being mostly interested in landscapes, the researcher emphasizes the neutral power of a place and a destructive force of human activity, which often leads to losing the initial genius loci. A place is characterized by five dimensions: items, order, character, light and time.

Tuan, in turn, wrote the following: "What is a place? What gives a place its identity [...]? These questions came to minds of the physicists Niels Bohr and Werner Heisenberg when they visited Kronberg Castle in Denmark. Bohr said to Heisenberg: 'Isn't it strange how this castle changes as soon as one imagines that Hamlet lived here? As scientists, we believe that a castle consists only of stones, and admire the way the architect put them together. The stones, the green roof with its patina, the wood carvings in the church, constitute the whole castle. None of this should be changed by the fact that Hamlet lived here, and yet it is changed completely. Suddenly the walls and the ramparts speak a quite different language. The courtyard becomes an entire world, a dark corner reminds us of the darkness in the human soul [...]. Yet, all we really know about Hamlet is that his name appears in a $13^{\text {th }}$-century chronicle. No one can prove that he really lived, let alone that he lived here. But everyone knows the questions Shakespeare had him ask, the human depth he was made to reveal, and so he, too, had to be found a place on earth, here in Kronberg. And once we know that, Kronberg becomes quite a different castle for us"'300.

299 Lenartowicz, Słownik... [Dictionary...], p. 68.

300 Y.F. Tuan, Space and Place, London-Minnesota, 2001, p. 4. 
We can characterize this approach in the following way: I am looking at a place where somebody used to be, used to live. Since I know this person's name and history, I can see that place from another perspective. I see it more fully and experience differently than I would if that place was anonymous. The long-gone presence of a human being gave this place a meaning, which I can now indirectly perceive.

It is different for Jewish hiding places that I am going to write about. It is impossible to locate a majority of those places. Some physically disappeared, like the shelters buried in city rubble, woodland dugouts that caved in and got taken over by weeds, stashes that were disassembled, and ruins that got toppled. Some disappeared after the war, because their context changed: ducts, tombs, and various buildings regained their primary functions and now nobody would have guessed that they used to be somebody's shelter. Some were used as a hiding place for such a short time, that the meaning given to them by somebody's instinctive gesture immediately vanished into thin air. It is extremely hard to track down the name and history of a person who lived in a particular place. From thousands of people hiding, only few left texts behind and wrote down their addresses. It can happen that even if we know a person and his or her story, looking for their hiding place will prove unsuccessful. Sometimes the person and a place meet in a symbolical space, as some hiding places were officially commemorated, such as the one on 4 Kopernika Street, apt. 21 in Warsaw. In 1989 the front wall of the building was decorated with a plaque that reads: "A specially built cloaked compartment is located in this building. During the occupation, Polish Jews hunted by Nazis were hiding here: a mother, a son and a daughter-in-law. The survivors commemorate this place for the posterity, Leon and Anna Joselzon vel Jolson". This way that place was elevated to a level of an official monument, a memorial site, just like the other ones scattered across Warsaw. It is labeled, yet still not many people know about its existence and reflected on it even in passing.

Therefore, this chapter is dedicated to a search for those hidden meanings. I begin with describing a hiding place by using the notions of: center and peripheries, oppositions of directions, sacred and profane, availability and boundaries (Space of a hiding place - in search for meanings). In the subchapter entitled Symbolical spaces of hiding places, archetypes and meanings encapsulated in texts, I analyze metaphors from the testimonies: desert island, Noah's ark, burrow, a besieged fortress, grave. In the last subchapter, I take time to give more attention to a universal metaphor of a prison. 


\section{Space of a hiding place - in search for meanings}

Let us start with the not yet listed basic categories characterizing space, the ones filled with meanings by human thought an experience. Everybody perceives those meanings instinctively, as the code of space is universal. Without it we would be unable to navigate the world. "People living in different cultures vary in a way they see the world, values they attribute to its parts, ways they measure them. [...] There are, however, some fundamental similarities transcending the cultural barriers. They derive from the fact that the man is the measure of all things" 301 . Taun draws this universality from the structure and value of human body, since a human being always perceives space in reference to oneself and assesses it accordingly.

\section{Center and peripheries, oppositions of directions, the sacred and the profane}

The notion of center and peripheries, present in all primal belief systems and ways of understanding the world ${ }^{302}$ has the previously discussed parameter of location and distance ascribed thereto. The center means authority, power, and accumulation of goods, being visible and important. Peripheries exist as a backdrop for the center, just like the subjects are a backdrop for the ruler. In this understanding, the hiding places are not just on the peripheries of the world, there are actually outside of the world. They are an area belonging to the least significant, most invisible people who have the least. The word "belonging" is not even entirely appropriate here, as those people give themselves a right to those areas, and nobody except for them intends to respect it. For the people hiding, the hiding places are a center of everything, the hub of their world, a point of reference. A hiding place is some kind of "here". To find one's "here" is the basic determinant of presence, a prerequisite of existence. "I am always here" ${ }^{\text {" } 03}$. A hideout is a place that accommodated my body, and even if I can transcend it with my thought, I will start every journey in a hiding place. I have to measure each distance starting from myself. If I leave my "here", its promises and limitations will come with me.

301 Ibid., p. 51.

302 M. Eliade, The Sacred and The Profane. The Nature of Religion, trans. W.R. Trask, New York 1957.

303 Y.F. Tuan, Space..., p. 47. 
When looking for another hiding place, I carry my "here" through successive stages of my wandering - until I find another place to be mine even for a short while. This understanding of center has tangents with the philosophical concept of Martin Heidegger, for whom "man is Dasein, and the Dasein's essence lies in its existence" 304 . Małgorzata Opoczyńska explains this formulation as "a human is a here-and-now-being"305. However, we do not know whether this category can adhere to the phenomena of a hiding place. A hiding place will remain a mystery for philosophers as well. A paradox, since it is a strain between the existence and the oblivion. A power play, a confrontation of the will of the weaker - the person hiding, and of the stronger - the executioner.

Let us look at space from the perspective of the category of direction. Out of the basic oppositions: up-down, left-right, front-back, the first one seems to be the most important in relation to the hiding places. The vertical category, which organizes and prioritizes the social world, is a qualitative category. What is up is good, sacred, God lives in the skies; at the bottom there is hell, Hades, Tartar. This opposition is connected with access to light and air, which are valuable. In the soil the insects live, blind moles digging tunnels never see the light, plants left in a basement produce pale, damaged sprouts. The inferior, lesser things stay in a dungeon. This opposition seems very useful when describing a postwar reality. However, it functions therein in a complicated and ambiguous way.

The war, as the cursed sacred time, rearranges, bends and even eliminates some hierarchies. The official system imposed from the outside is a synonym of evil. The people, who were previously treating some place as a home, are now called the Untermenschen. Underneath, at the bottom of the official, tainted reality, an alternative emerges.

Better world goes to the underground. The underground state is born to fight for the old values and to preserve goodness. The Germans have placed themselves at the top of a pyramid, yet they are an incarnation of evil. The order and hierarchy of the time of peace are inverted. It would seem that everything that was underground, illegal, invisible, would be unequivocally affirmed. Yet a Jewish hideout has no place in this new order. It is excluded. For the Jews it is a salvation, but for the Poles it is often something inconvenient, which is better not noticed, which one should not boast, or even something that one can use in an undignified way. Underground Jewish bunker and underground Poland are not

304 M. Heidegger, "Introduction to What is Meaphysics?", trans. W. Kaufmann, in: Pathmarks, ed. M. Heidegger, Cambridge 1998, p. 283.

305 Wprowadzenie do psychologii egzystencjalnej [Introduction to Existential Psychology], ed. M. Opoczyńska, Cracow 2004, p. 47. 
elements of the same order. This is why the reversal of the up-down hierarchy is only partial. From an alternative route, I came to the same conclusions as I did in Chapter 2, when, inspired by Gross, I contemplated the place of a Jewish hiding place in the system of Polish grey area.

In another, more narrow meaning, this hierarchy, which is deeply embedded into human subconscious, was useful in selecting a hiding place. Choosing places located "at the bottom" was a common tactic, especially when it came to temporary hiding places. People moved to a basement, cesspool or a hole with garbage, gutter, or a tomb. Finally - they would dig dugouts and bunkers underground. They moved to the underground. These places were usually disgusting in one way or another. They were repulsive or frightening, and that is why they were located so low. This repulsion was supposed to repel people, deter them, increase a chance of not being seen.

This category is strictly connected with another opposition: erect-reclined. Upright position is the measure of humanity ${ }^{306}$. Homo erectus is almost a homo sapiens. Only a helpless, incapacitated people unable to act are lying down: the sick, children, body in a coffin. Subordinate people without their own will crawl or curtsey. Humiliation connected with an inability to stand up is a part of the experience of a hiding place. Its construction can create a need of lying down, i.e. compulsory inactivity. At the same time a recumbent body position is assumed when going to sleep. It means relaxation, a sense of security in which we trustingly give our bodies to the custody of the night. Thus, a hiding place, where there is no room to lie down, where one has to nap squatting or sitting down, can also be humiliating and unspeakably tiring.

The opposition of sacred-profane is parallel to the up-down opposition. When looking at the living conditions, the whole context of formation of such places, one can assume that a hiding place is exclusively a part of the profane area. No death, no birth, no prayer will make that area filled with a biological smell of fear sacred. In the following part of the chapter I am writing about the idea of Kiddush Ha-hayyim, the sanctification of life, according to which a hiding place, as a place where the divine order to protect a living being is observed, acquires qualities of a higher order.

306 Y.F. Tuan, Space..., p. 35. 


\section{Availability and boundaries}

There are important categories connected with availability of space. It is one of the key concepts in the case of a hiding place. The essence of a hiding place is embodied by a state of "translucency", it is a kind of magical place, opened only with a spell. It is available to the people who need it and is presumed to be impregnable to anyone who could prove to be a threat. This understanding of a hiding place falls within the concept of boundaries. Boundaries are there to separate one thing from another, sometimes similar areas, to tell them apart, sometimes different ones, to keep them from permeating one another. Boundaries are there to make the access more difficult, but also to establish the end of something. They serve security, integrity and orientation. They can be formal and informal, physical and conventional. Sometimes all one has to do to cross a border is to find an entrance. However, if the people occupying given space are still resisting, not letting somebody in, one has to use force or a trick. Sometimes, it is enough to know a password, "a spell". A password allows people to tell the difference between a friend and a foe, although it is not guaranteeing a foolproof selection of the newcomers: it can be easily intercepted.

"An area can be also controlled by the supernatural, and then it sometimes happens that crossing borders at particular times can expose a reckless visitor to danger" 307 . Traditionally a cemetery is such a place. It is scary to go there at night. Anna Zadrożyńska lists other such places: swamps outside a village, forests, marshes, fallow lands, and places generally known as "no-man's-land". In a city landscape those places can include deserted factories, empty "hunted" homes, rail yards, bushes on the side of a road ${ }^{308}$. For example, during the war the ruins of the demolished Warsaw Ghetto, which were later used by the Germans as places of execution, were referred to as a "hunted" area with negative connotations. Some places would not automatically get a negative status. Depending on the context, they could have become an impromptu monument to martyrdom, where people would light candles and demonstrate a spiritual resistance. The role of a literary symbol of such elevation can be played by a place of death of a character in Andrzej Szczypiorski's novel entitled Poczatek [The Beginning], a tailor named Kujawski, who was shot "against a tenement wall, and when the executioners thrown his body onto a platform and drove away, some woman

307 B. Jałowiecki, M. Szczepański, Miasto i przestrzeń... [City and Space...], p. 314.

308 A. Zadrożyńska, Homo faber, homo ludens. Etnologiczny szkic o pracy w kulturach tradycyjnej i współczesnej [Homo Faber, Homo Ludens. Ethnological Study on Work in Traditional and Contemporary Cultures], Warsaw 1983. 
dipped a handkerchief in the tailor's blood, which clotting on the pavement, and took it with her as a seal of human martyrdom" 309 . They can also become a frightening, strange space, which attracts evil and is better left alone. By contrast, a villain from the same book, a Jewish szmalcownik, Bronek Blutman ${ }^{310}$, dies in such a space, in "the ghetto ruins". Here it also happens, like in the up-down opposition, that the cursed places, no-man's-lands, ruled by the bogeymen of collective imagination, are consciously selected as hiding place. They are less available, scarier, and thus safer.

A passage is a spatial category closely related to the border. It can be embodied by a door, gate, doorstep, and - in a slightly different meaning - a bridge. The continuity of space is interrupted by a door or a doorstep ${ }^{311}$. Looking from the inside of a hiding place, all discontinuity means not only a chance to go outside, but primarily a gate through which someone can enter. You can never know if the one who enters will turn out to be a friend or an enemy. Even simple intruders, uninvited guests, surprise visitors, are not simply unwanted. They could be harbingers of death.

When exiting a hiding place, literally and figuratively crossing the threshold, people chose their fate. They choose it not completely consciously, as no collection of experiences and information gives anybody any guarantees. Nothing is certain but fear and danger. When talking about exiting a hiding place, a rite of passage comes to $\operatorname{mind}^{312}$. Like a majority of anthropological topoi, in respect to a hiding place, it is unveiling new complicated meanings. Marzena Gregier writes about the rite of passage in connection to children from the Warsaw Ghetto getting out to the Aryan side. She analyzes the stage of severing ties (forgetting one's identity, getting separated from one's family) and the moment of exclusion, being suspended in a void between two worlds. Now, according to Gennep's pattern, there should be a ritual of inclusion to a new community. Meanwhile Gregier notes that in this particular situation "there is no rite of passage, a child is in a way left in the liminal period. [...] This passage is unsuccessful, unfulfilled, even though the child is physically on the other side. The passage is incomplete, it is [...] a constant state of transition, adjusting to new situations, maneuvering, disappearing,

309 A. Szczypiorski, Początek [Beginning], Poznań, no date, p. 121.

310 Ibid., p. 217.

311 See M. Eliade, The Sacred and The Profane...

312 See A. van Gennep, Rites of Passage, M.B. Vizedom, G.L. Caffee, London and Henley 1977. 
immersing into the space, "becoming invisible"'313. The last stage of the ritual, being included into a new status, is also not fulfilled. An interrupted ritual is not performing its function, a person is still an intruder. The fiasco of the rite of passage can be similarly described on a different, more general platform, in relation to all hiding people. A man sentenced to death wishes to get to the side of life. $\mathrm{He}$ abandons a dangerous place, full of people just like him, where the executioners can show up any moment. His desire is to become a member of a community of the people who are allowed to live. He knows, however, that this community will reject him on principle, at best offering him a place on the outside, in hiding. A place where, perhaps, a tacit agreement not to notice will be concluded; a place that will survive, if nobody breaks that agreement. A crevice. Hence that person tries to find a place for himself, wishing to decide at least one matter, to carry out his will in this final narrow field, which was left to him perhaps due to an oversight. In the hiding place that person immerses into a liminal period, still alive, yet expecting death at any given moment. Breaking the irreversibility of a ritual he can go back to the community of the condemned - all he has to do is to get out of the hiding place and give himself into the hands of the executioners. Wishing to at least reach the end of the liminal period, he waits. He waits for an end to some period, end of a reign of a system that sentenced him to death. We are unable to trace a life of a hiding person to find out whether or not the rite of passage was completed. We can, however, describe a hiding place as a limbo.

Formation of hiding places has transformed the primary, most basic meaning of simple places. Anything could have become a hiding place: a basement, where one would normally keep coal and vegetables; a closet, where clothes should be; a chimney, accommodating only smoke, or maybe a place where some reckless crows build their nests; attic - a junk room; a barn filled with hay; forest inhabited by wild animals and figments of folk imagination... How did the meanings of those places change when they became hiding places? The primary meanings were joined by an element of secrecy, hidden agenda, and an invisible layer. On the one hand, their primary function was pushed into the background as compared to their new basic function of sheltering human beings. On the other hand, it gained a special meaning as a mask, sham, façade ${ }^{314}$. While not being only a closet, a simple basement, just an attic, those places were still supposed to

313 M. Gregier, “Zniewolone dzieciństwo". Sytuacja dzieci żydowskich w getcie warszawskim i po aryjskiej stronie ["Enslaved Childhood". Situation of Jewish Children in Warsaw Ghetto and on the Aryan Side], master's thesis, Warsaw 2004, p. 48.

314 E. Goffman, Człowiek $w$ teatrze... [Presentation of Self...]. 
keep appearances of normality and stability in order to perform their new function as efficiently as possible.

\section{Symbolical spaces of hiding places, archetypes and meanings encapsulated in texts}

If a space has an attribute of infinity, it is not reflected by its expansion, but in its reduction. If for no other reason, then because reducing space turns out to be, surprisingly, more logical. It is more organized and has more names: cell, toilet, grave. The spaces only make big gestures.

Iosif Brodski $\mathrm{i}^{315}$

"A safe place" saving from the Shoah is the most basic meaning of a hiding place. However, authors of the texts who used to stay in such places, found other indirect or additional meanings in them. A hiding place is a confined space that is reduced and locked. When looked at from the outside it was compared to many other places. The authors of the texts themselves use the following expressions, either consciously or not, ascribing a hiding place into the models and structures already functioning in society and culture. Of course, those metaphors are not disjunctive; one text describing one hiding place can use several of them. Each of them is emphasizing some aspects of living in a hiding place. I have gathered those expressions primarily from longer texts, such as memoirs and journals. There usually is no place for them in shorter testimonies. I have chosen those metaphors, which come up in numerous texts, therefore seem to be the most accurate in describing the space of a hiding place. In the beginning, I shall present two models borrowed from a treasure trove of cultural motifs: desert island of Robinson Crusoe and the biblical Noah's ark. The next two metaphors are based on phenomena that require no cultural references, and each of them brings up certain characteristics of a hiding place. Those are a burrow and a besieged fortress. I discuss the metaphor of grave in more detail. A separate subchapter is dedicated to the metaphor of a prison. It is easy to notice a common tangent of all those metaphors - each of them is telling a tale of exclusion, isolation, and loneliness of the hiding people, even if the tale is a bit different each time.

Before I start discussing the individual metaphors, I would like to highlight their particular status. Just like the hiding place itself is determining a person located inside, who is hereinafter referred to as "hiding", almost every following metaphor is automatically extended to the residents of a hiding place. Therefore,

315 J. Brodski, W półtora pokoju [In one and a half room], in: J. Brodski, Mniej niż ktoś. Eseje [Less than Somebody. Essays], Cracow 2006, p. 330. 
the people who live "like on a desert island" are now Robinsons, and the ones who stay "in a burrow" compare themselves to animals. The authors defining their hideout as a grave write that they themselves are "buried alive". The metaphor of a prison also makes people inclined to call themselves prisoners. Therefore, a description of a space of a hiding place cannot be separated from attempts to define one's own existential experience, referring to one's fate with models and metaphors available.

\section{Motif of a "Robinson" and a desert island}

Dawid Fogelman wrote the following about his hiding place in Warsaw: "We live here just like Robinson Crusoe. The only difference is that he was free, could move freely, and we have to live in hiding. We are just like on an island, there are mines around us"316. The metaphor used by Fogelman entered the vernacular, even though it was not directly thanks to his text ${ }^{317}$. Władysław Szpilman was the most famous "Robinson". He was hiding for weeks in Warsaw, which was desolate after the uprising. The term "Robinson Crusoes" became customary in reference to the group of people similar to him, who were hiding in the ruins of a deserted city. It is most commonly used in reference to Warsaw. The description of an experience of "Robinson Crusoes" is presented in Chapter 1.

Here we are probably faced with an almost total exclusion from society and an almost complete form of isolation. A model of a desert island assumes lack of outside help (even though Szpilman has met his savior in the end) caused by the fact that there were practically no other people in the city except for the people hiding there. "Robinson Crusoes" become witnesses of the transformation of a living city organism into lifeless ashes. The moment they realize it means adapting to the new model of life. Strength, ingenuity and creativity in making a place for themselves from nothing are the most important here. The "Robinsons" experience includes exploring the space around them, looking for water and food, transforming spaces and objects depending on their needs. It often means living in extreme poverty, hunger, a return to the most basic techniques of dealing with everyday life.

316 D. Fogelman, Pamiętnik pisany w bunkrze [A Journal Written in a Bunker], "Biuletyn ŻIH” [Bulletin of Jewish Historical Institute] 1964, No. 52.

317 Later "cavemen" term was used as well. It first appeared in a bulletin of Jewish Press Agency on $26^{\text {th }}$ January 1945 (See Dzieje Żydów w Polsce 1944-1968. Teksty źródłowe [History of Jews in Poland 1944-1968. Source Materials], prepared by A. Cała, H. Datner-Śpiewak, Warsaw 1997). 
Feature emphasized by choosing this metaphor is independence of the hiding people, their loneliness and lack of contact with the outside world. It seems that the "Robinsons" have to some extent achieved a utopian project of living outside a society, alienation. For this is not only marginalization, but a literal departure from the world and social space. Such a state could not last very long. The authors of the texts who use those metaphors have keenly deciphered their status of hiding people that nobody knows about. There is no contact with them, so nobody can help. What is more -the space in which their hiding places are located is also uninhabited ("excluded areas" from Chapter 1).

\section{Noah's ark}

Noah's ark is an archetype of a place saving people from a cataclysm. It is excluded from the hostile surrounding area, it transports people on its deck to a better, safer world. A thought of Noah's ark is raised by a motif of "the sole survivors" repeated in the testimonies. When hiding in isolation from the world, with no information about their loved ones or neighbors, some people probably assumed that nobody else from their town stayed alive, that there were no other Jews left. A story of young Szajk Nussenbaum from Nowa Wola near Kozienice is an illustration of such an attitude. The boy born in 1934, after years of hiding "sometimes [...] on some attic, sometimes in a barn, sometimes in some dungeon" and years of wandering from one pen to another, admits in his account: "After the liberation in [19]45 I had no idea that there were any Jews left, I thought they were all killed"318.

An association with Noah's ark is an emphasis on understanding a hideout as a place that saves lives. This motif is literally present in some of the stories. Czesława Fater wrote: "A sudden wind picked up. [...] I thought to myself: let our cottage get transformed into a Noah's ark, sail somewhere far away and make it to some land where the Jews would be allowed to live... I remembered the legend about Moses, who begged the Lord to see the Promised Land before he died"319. Jan Kostański has also described a hiding place as a ship, referring to nautical superstitions: "Mice were keeping us company, they were nocturnal as well. They were petite, since it was the wartime, but lively, we had something to look at. They cheered us up. Just like the sailors, we believed that our ship won't sink as long as they are here with us"320.

\footnotetext{
318 AJHI, 301/3003, Testimony of Szajk Nussenbaum.

319 C. Fater, Aniołowie bez skrzydet [Angels without Wings], Warsaw 1995, p. 97.

320 J. Kostański, H. Grynberg, Szmuglerzy [Smugglers], Warsaw 2001, p. 126.
} 
There is also an indirectly expressed turn toward the future in this model of a hiding place. Firstly, it is writing a journal as a memento for the posterity. If there are no more Jews, the survivors' duty is to bear witness. The perspective of a witness creates a tension between an illusory security inside a boat and the awareness of the frailty of its construction. A tension between active and passive attitudes of people looking for help on their own and a feeling of powerlessness in face of the elements. Jacek Leociak wrote about the character of such texts, also referring to similar metaphors: "There is something that accompanies authors of the Ghetto texts. Something incredible joins the ordinary state of being locked in the preset - it is being locked in the scope of developments that one cannot influence, yet to which one is completely subjected. The chain of events completing the horizon of textual 'here and now' turns out to be a catastrophe consuming not only the writer, but a whole collective. A diarist from the ghetto is not so much carried by the waves of time and - not knowing what the future might bring - captures the fleeting today, but is rather drowning in the overflowing terror of the present" 321 . In such an understanding of a hiding place a holistic vision of the world stricken with war is important. It is just like a deluge, a homogeneous, gigantic threat that cannot be stopped by one person. The constructors of hiding places (or kind-hearted people who would take the hiding people under their own roof) are like carpenters building a ship. There is no way to fight the deluge, the only strategy is to wait out the cataclysm in a safe place. A boat on a troubled ocean on the cover of Kurt Lewin's book entitled Przeżyłem [I Survived $]^{322}$ is an accurate and literal illustration of that motif. The editors have chosen a reproduction of a fragment of a trim of an interior of the synagogue at Braci Michnowskich Street in Lviv: a ship with a Star of David on its sails ripping through the waves. A feature emphasized by this metaphor is the faith and persistence. A hiding place - Noah's ark - is therefore a place directly facing the future. It is an optimistic metaphor. It is so because it assumes existence of a supernatural force that can be of assistance in a hopeless situation. Resorting to a divine intervention can obviously be a proof of religious attitudes of the authors, but also of their feeling of being separated from this world. Hence the motifs of isolation and alienation from the society emerge once more, but the strategies assumed here are completely different from the ones of the "Robinsons". They could only count on themselves, their hiding place-island was an area of freedom

321 J. Leociak, Tekst... [Text...], p. 24.

322 K.I. Lewin, Przeżyłem. Saga Świętego Jura spisana w roku 1946 [I Survived. A Saga of Saint Yur Written in 1946], Warsaw 2006. 
of action and independence in solving all their problems, without counting on the outside help. People who stayed in a hiding place-ark were not completely entrusting in the rest of the society as well, as they were pushed to that society's margin; they do not count only on themselves either, but have faith in God who will save them, if that is His will

\section{Burrow - cave}

Comparing a hiding place to an animal burrow immediately implies comparing the hiding person to an animal. Animals are lower in hierarchy than humans; no other animal species has created a civilization comparable to the man-made one. Hence comparing people to animals is negatively characterized, means primitive conditions, exclusion from human society, extreme poverty, not having any rights. In many texts, this motif is actually in general extended to the German terror which caused the Jews not to be perceived and treated like people. It was a process spread out in time, and culminated in displacement actions and liquidations of the ghettos. Stefan Ernest wrote: "In the Jewish district of the second period there are various mutual conflicts, which are understandable against the backdrop of living conditions created by the Beast. They would usually end in an amicable mutual compromise: 'Give it a rest, we are only human'. Yes, we were still people then, after all. But soon we were transformed into hounded animals, we were chased, caught, hunted" ${ }^{23}$. Baruch Milch also compares the tortured Jews to animals when describing a situation in Tłuste: "One Jewish neighborhood after another was disappearing from the horizon. They had to reduce five neighborhoods in our kreis to two. Just like the poisoned mice before their lair is destroyed, desperate convicts were running around looking for a window to escape, a crevice to hide in, but all in vein" 324 .

Comparing a hiding place to a burrow was especially common for the residents of hiding places in the countryside and in forests. Dugouts, the holes dug in the ground, are physically identical to the animal burrows. The fate of a person hiding in such a place brings to mind an association with the wild game. An example of a literal infiltration of the testimonies by this association is the title of Artur Schneider's book Jak ścigane zwierze [Like a Hunted Animal]. Schneider

323 P. Ernest, O wojnie wielkich Niemiec z Żydami Warszawy 1939-1943 [About the War of Greater Germany and the Jews of Warsaw 1939-1943], Warsaw 2003, p. 356.

324 B. Milch, Testament... [Testament...], p. 145. 
wrote down the following thought: "Hiding makes sense only when it is shrouded in mystery, otherwise it is no longer hiding, it can become a trap"325.

There are many animal species - some passive and supine, created to become pray for the stronger ones (like the gentle sheep or deer), some are wretched and disgusting, eradicated by people and causing them avert their gaze (like rats or insects), some strong and independent, who can survive the worst, not backing away from a fight for life (like wolves). It depended on the situation and the context to which of those categories the hiding people would symbolically ascribe themselves. However, comparing themselves to animals usually meant stressing their passivity and helplessness consistent with aforementioned pattern of the chase, in which an animal does not have a chance against the armed hunter and the hunt. Hence negative expressions were the most common. Jan Kostański, a Pole who lived in a bunker in Warsaw with four of his Jewish friends, wrote: "We spent the first night lying on coal, quiet like whipped dogs, pretending to sleep" ${ }^{\text {"32 }}$. Kostański used another negative "animalistic" comparison when complaining about terrible hygiene: "We had plenty of soap but there was no way we could wash up and we

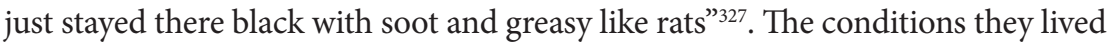
in made the author of the text compare them to animals practically in every situation: "We would drink straight from the bucket like horses - there is nothing better in this world than fresh cool water" 328 . Jochwed Kantorowicz used an animal analogy in her account to stress the sorrowful fate of homeless girls wandering and looking for a shelter to no avail: "We had nowhere to hide when it was raining. We were wandering the forest like stray dogs" 329 . Those negative comparisons bring the German anti-Semitic propaganda to mind (for example the famous "Jews - lice - spotted typhus" poster). Nonetheless, it is hard to determine, if the authors of the testimonies have in fact internalized the German propaganda comparing themselves to animals, or if it was simply a metaphor that seemed the most obvious to them, given the circumstances in which they were.

Animals act instinctively, they are a part of nature, know secret passages and have their ways of surviving. Kantorowicz highlighted the fact that the people can actually envy some of the animals' competences, but living in a forest they have to overcome their limitations. When the two girls from Warsaw (Jochwed was hiding with her sister) attempted with huge difficulties to create a dugout

325 A. Schneider, Jak ścigane zwierzę [Like a Hunted Animal], Lublin 1993, p. 188.

326 J. Kostański, H. Grynberg, Szmuglerzy... [Smugglers], p. 123.

327 Ibid., p. 123.

328 Ibid., p. 124.

329 AJHI, 301/2493, Testimony of Jochwed Kantorowicz. 
for themselves, it turned out that they are incapable of doing something that any animal can do. This made them determined to finish what they have started: "Sister told me: 'Hares dig holes too. Are we worse than hares?"”330. Their attempt was successful in the end. The sisters made a few more dugouts, gradually mastering the skill and measuring up to the animals. After an extended period of living in hiding, the residents of woodland hiding places, trying to coexist with the nature, and also the people hiding in city ruins, often compared to a forest or a jungle, would become as capable as wild animals. Irena Grocher, who was hiding with a group of people in the ruins of Warsaw, wrote the following on $13^{\text {th }}$ January 1945: "In the attic. [...] meanwhile, every morning, when it is still dark, we had to climb to the second floor like cats"331.

By comparing themselves to animals, the people hiding had to endure the physical presence of the real animals as well. It would often happen that uninvited, sometimes even dangerous guests would came - the rats. Dawid Fogelman wrote: "I have to say that we got new tenants. Rats moved in with us. They are as big as cats and won't let us sleep at nights. Well, there's nothing we can do, we have to get used to them. Nobody knows what might happen next"332. Fleas and lice were a common experience in long-term hiding places, along with other vermin. Eventually it was possible to even create a comparatively conflict-free "ecosystem" with them. Landsberg notes: "Fleas started bugging us again. We have to start our campaign anew. Those beasts! Not cold, nor humidity, nor any other bloody thing can get rid of them. We live in peace with centipedes, good old things, they are just a bit ugly and unpleasant to the touch"333. Another comparison in the scope of negative characteristics is a "cave". When looking at themselves and their efforts in searching for shelter, authors of the texts see prehistoric people. This theme emerged in Menachem Katz's story as well. He called his hiding place "a cave of a prehistoric man" ${ }^{334}$. Landsberg has also ironically noted when the light got installed in his hiding place: "The light, at last! A light bulb hanging from a nail stuck into clay looks ridiculous. What a paradox! Primitive cavemen are reading German newspapers... by electric light" ${ }^{\prime 35}$.

Both living in a burrow and in a cave mean reversing the course of history. Animals, prehistoric men, children: each of those categories comes to mind of

330 Ibid.

331 AJHI, 302/103, Journal of Irena Grocher.

332 D. Fogelman, Pamiętnik... [A Journal...].

333 AYV, 033/1099, Journal of M. Landsberg.

334 M. Katz, Na ścieżkach... [On Paths...], p. 248.

335 AYV, 033/1099, Journal of M. Landsberg. 
the hiding people describing their lives. Common characteristics of the three groups are summed up by psychology of architecture: "At some point in development majority of children wants to create some sort of a shelter for themselves. It could be a real cavern dug in a turbot or a primitive shack put together out of untreated boards. It is often just a secret inch of shrubbery or a tent made out of a rug hanging between two chairs. 'Playing cavemen' can have thousands of varieties, but the varieties have one thing in common: locking the space for the exclusive use of a child. Many animals can create shelters for themselves as well by digging a hole in the ground or by building some sort of a home above ground. Each species always does it in the same way"336.

The feature emphasized by choice of this metaphor is the exclusion from the human society. Therefore, it is also a metaphor which clearly shows that the hiding people were aware that they are placed outside the society. That exclusion is so strong that it even extends to being a member of the humankind itself.

\section{Besieged fortress}

Essence of this model of a hiding place is not only the hiding itself, but also active opposition. The hiding people have a completely different attitude toward the outside world. They are not only avoiding unnecessary contacts, they are isolating themselves and even trying to painfully bite the enemy. We can see a truculent, offensive orientation here. This combination means a high level of confidence, primarily stemming from possessing weapons, which changed the status of a hiding person. People who have a gun are not helpless victims. They can not only counter the attack, but even attack themselves, be active, make their own rules. In that sense, this model is best complimented by the places inhabited by the people who chose to fight - military bases of insurgents, forest camps of partisans $s^{337}$.

Similar situations occurred in urban hiding places as well, but they clearly had a much smaller scope. Cases of Warsaw's "Robinson Cruzoes" having a gun were quite frequent. Stefan Chaskielewicz describes the following situation: after the surrender of the Warsaw Uprising, he was hiding in ruins of a building at 131 Marszałkowska Street. From there he and his friend Skwirski would go to the nearby homes looking for food. One day in a booth on a corner of Sienna Street they found, among other things, a sniper rifle. The find made Chaskielewicz

336 P.E. Rasmussen, Odczuwanie... [Experiencing...], p. 33.

337 See N. Tec, Defiance. The Bielski Partisans. The Story of the Largest Armed Rescue of Jews by Jews during World War II, New York-Oxford 1993. 
ecstatic. In his conversation with Skwirski he said that they had to use it: "we have to shot at Germans from somewhere they wouldn't see us to give them a sense of insecurity when penetrating this area of Warsaw. This way they will be too afraid to proceed and will not bother us anymore. I knew that this logic was a bit far-fetched, and it was essentially not the point. I think I just wanted to get revenge for all the evil"338. Finally, Skwirski and he went "to action" twice, each time firing thrice. During the third attempt "we lost the rifle when climbing, it fell into the darkness from the second floor at a pile of rubble. We couldn't see it. This is how our military action ended"339.

A fortress-hiding place is also a place which, for some reason, is considered impregnable. It is surrounded by walls that are especially hard to storm or just give a subjective sense of security. This term was used e.g. by Baruch Milch, who was describing a hiding place in a warehouse attic: "yet I felt safer than at home", and later: "me and my wife left our fortress"

Another role of a hiding place as a fortress is the importance of civil resistance. Hiding in itself has a value, as it is a refusal to die which can be interpreted as a form of fighting back, a desire to disrupt the oppressor's plan. Numerous studies $^{341}$ place the subject of hiding, crossing to the Aryan side, escaping transportations or refusing deportation in chapters on Jewish resistance against the Germans. It seems justified, especially in the context of defying the popular theory on the passivity of the victims.

Another motif we can address is the religious idea of Kiddush Ha-hayyim the sanctification of life ${ }^{342}$. "There is another religious category, closely connected with sanctification of God's name. It is Kiddush Ha-hayyim - sanctification of life. It emerged when the Jews were threatened by unconditional death, regardless of their creed, what where their views and whose subjects they were" ${ }^{\prime 34}$. This term was popularized in 1940 by a Rabbi from Warsaw, Icchak Nissenbaum. In his

338 P. Chaskielewicz, Ukrywałem się... [I was Hiding...], p. 85.

339 Ibid., p. 86.

340 B. Milch, Testament... [Testament...], p. 159, 163.

341 Ruch podziemny w ghettach i obozach (materiały i dokumenty) [Underground in Ghettos and Camps (Materials and Documents)], prepared by B. Ajzensztajn, WarsawŁódź-Cracow 1946; M. Fuks, Z dziejów... [The history...]; P. Krakowski, Żydowski opór w Generalnym Gubernatorstwie [Jewish Resistance in General Government], in: Akcja Reinhardt... [Reinhardt Action...]; M. Grynberg, Żydzi... [Jews...]

342 See I.J. Rosenbaum, The Holocaust and Halakhah, New York 1976.

343 A. Wąsowicz, Życia nie starczy... [Life is not enough...] (A. Wąsowicz interviewed by Piotr Paziński), "Midrasz" 2007, No. 4(120). 
response, he wrote: "The hour has come not of Kiddush Ha-shem, but of Kiddush Ha-hayyim, sanctification of life. So far our enemies demanded only the Jewish soul, and a Jew, sacrificing his body, was sanctifying the God's name. Now the enemy is demanding the Jewish body. This, in turn, makes it the Jew's duty to protect $i t^{\text {"344 }}$. From there on the sanctification of life was variously interpreted: as a dignified behavior giving others courage, as refusing risky behavior, which could unnecessarily endanger human life. In this context choosing a hiding place appears to be an ambivalent action. In case of e.g. displacement actions, when the people were still not aware that being displaced in fact meant a death sentence, obeying orders seemed to be a wiser choice. Hiding meant a risk - people found in hiding places were risking death. With a rise of the awareness of the inevitability of the Shoah, which would come whether or not the Jews would obey German orders, the thought of hiding became compliant with the idea of Kiddush Ha-hayyim. I have found no testimonies with this sentiment (probably because of the fact that we practically have no accounts from religious Jews). I believe, however, that looking at a hiding place from the perspective of Kiddush Ha-hayyim idea is justified: it is a sacred place where the life is protected according to God's will.

\section{Grave}

In Polish culture, there are metaphors of a grave as a homeland. Continuity of tradition requires access to land with graves of the ancestors. Funeral ceremonies and worship of burial grounds of heroic members of the community are parts of a process of preserving national identity. As a result, the territory of a cemetery is important as a memorial site. BY contrast, in folk culture a cemetery is a borderland, a sacred space, which is at the same time frightening, as it is ruled by spirits $^{345}$. A cemetery as a whole was always respected, even if a burial site of individual people did not use to have much significance. Graves were not marked in any special way, after burials people would simply create mounds which gradually faded away. Name plates appeared on village cemeteries in the interwar period. People could pray for their loved ones everywhere at the cemetery, not necessarily at "their" grave. "Generations had a short memory. Graves of at most two generations were preserved. A village cemetery was literally expressing the

344 Ibid.

345 See A. Spiss, Wiejskie cmentarze w Polsce [Jewish Village Cemeteries], in: Śmierć, przestrzeń, czas, tożsamość [Death, Space, Time, Identity], eds. K. Grodziska, J. Purchla, Cracow 2002. 
impermanence on this earth, so the graves were also disappearing to make room for the new ones"346.

Significance of a tomb and cemetery in Jewish culture is addressed e.g. by Leszek Hońdo ${ }^{347}$, who stresses how closely those two places are associated with home in Judaism. In the Bible, there are metaphors presenting a cemetery as a: house of life, sacred place, house of graves, good place, departed's yard. Religion is precisely stipulating burial methods and ways of handling the remains. Burying a body intact is an important religious obligation. Genesis commands to bury a body in the ground. Aleksander Wąsowicz explained the sanctity and the eternal character of a cemetery specific to Judaism: "A cemetery is eternal, even if there are no matzevahs in it. [...] Grave is more important than a headstone. [...] For the Jews knowing where the bones are laid, their actual place in the ground, is the most important. A grave is treated literally. It is not a matter of a grave in a symbolical sense, a memorial site, but a physical presence of the bones" ${ }^{\text {"34 }}$. A grave can be disturbed only in exceptional circumstances: in a case of a temporary wartime cemetery, when the deceased is to be buried in Israel or when the cemetery is in danger of being washed out by a river.

The remains must not be disrespected. There is a whole list of things one is forbidden at a cemetery, including eating, drinking, attending to physiological needs. In fact, the living should limit their presence on the cemetery grounds to essential minimum. "Halakha specifies that nothing should be done within 7 and a half feet from a grave, as this territory belongs to the grave, to the deceased. Other rules and prohibitions stem from that. Even old trees belong to the dead, as their roots are touching upon their bones, and therefore should be respected as well. Generally everything happening on a cemetery, e.g. each prayer should be somehow connected with the dead. We don't eat or drink at a cemetery not only because it is rude. There is a deeper meaning to that. In the presence of the deceased one should not do things connected with any mitzvah, as the dead cannot obey its rules. After eating we say an appropriate blessing - since the dead cannot say blessings, we abstain from eating"349. In a way, a space of a Jewish cemetery and the space of a grave is more sacred than the space of a synagogue.

Graves in context of Jewish hiding places have to first appear not as a metaphor, but as a real place - real cemeteries and tombs, where people looking for

346 Ibid., p. 221.

347 L. Hońdo, Przestrzeń żydowskiego cmentarza [Space of a Jewish Cemetery], in: Śmierć, przestrzeń... [Death, Space...].

348 A. Wąsowicz, Życia nie starczy... [Life is not enough...]

349 Ibid. 
a safe place to hide would often end up. Aleksandra Bańkowska wrote the following on the subject: "Cemeteries were peculiar areas where the refugees would often hide. They lived in buildings by a cemetery, in dugouts and tombs. Samuel Rosen's family prepared a place for them in a tomb, they built bunks, shelves, gathered candles from graves for interior lighting and, preparing for the winter months, dug a shelter underneath the floor" 350 . We have to remember, that this was probably not the case of cemeteries of all faiths. The above-mentioned Samuel Rosen's shelter was located "at a Catholic cemetery, in family tomb of priest Fiałkowski" 351 . Jochwed Kantorowicz remembered where she and her sister were looking for a shelter: "On the day of the manhunt we went to a Jewish cemetery near Tarczyn. The cemetery looked awful. Numerous graves were dug up, many tombstones turned. The cemetery was like an empty field. There was a Rabbi's grave at this cemetery and we wanted to hide there. We didn't stay there long" ${ }^{\text {"352 }}$. In both cases different strategies were employed. The girls, probably treating the tomb like a quick stop on the way from one hiding place to the other - in her accounts Kantorowicz describes a dozen or so of hiding places - spent some time next to the body of the buried Rabbi, not even thinking (there is nothing about in the account) about emptying the grave. In contrast, Rosen, preparing a long time "apartment" (as he called it), took coffins of the priests out of the tomb with a help of a Polish undertaker and buried them somewhere else.

A quote from a modern autobiographical novel by a Ukrainian writer shows that a grave as a hiding place is a motif present not just in the history of the Shoah in Poland. Marina Lewycka writes about her father, a soldier in the Ukrainian army, who was hiding from the Germans (or NKVD, various versions of the family legend are not consistent) in 1941: "In the end father did not ran along with the army. He snuck out from the ranks of his regiment and found a hideout. He hid in a ruined tomb in an old Jewish graveyard in a quiet and green part of the town. He shoved back the stones behind him and hid just under the nose of death. Sometimes, when he was crouching like that in the dark, he would hear the voices of grief-stricken Jews mourning their loved ones right above his head. He stayed in the cold, damp silence for over a month. He ate what he had on him, but when the supplies had run out, he started eating grubs, snails and frogs. $\mathrm{He}$ drank the water that soaked inside when it was raining and created little puddles on the ground. He contemplated the proximity of death, and his eyes were

350 A. Bańkowska, Las jako miejsce... [Forest as a Place...], p. 42.

351 AJHI, 301/1935, Testimony of Samuel Rosen.

352 AJHI, 301/2493, Testimony of Jochwed Kantorowicz. 
getting more and more adjusted to the dark. It wasn't totally dark in the tomb. There was a gap between the stones, letting in the sunlight at a certain time of the day. When he stuck his eye to that gap, he could see the outside world. He saw the tombstones, partially overgrown with roses, and behind them a cherry tree, heavy with ripe fruit. He got obsessed with that tree. He would watch the ripe fruit all day long while he had to prey on the grubs in the darkness" ${ }^{353}$.

Let us try to look at a grave, a tomb, as a metaphor. It is very frequently used by the authors of the texts. The first thing that comes to mind when we hear this comparison is a thought that staying in a hiding place is no longer treated as life. People in "a tomb" see themselves as if they were dead. Going into a hiding place brings to mind descending to hell (Irena Grocher: " $24^{\text {th }}$ December. Christmas. We went to the sewer at 8.00 AM. It is hard to describe what a person feels when going down to that hellhole, which, however, saved our lives (24 people)"354), or to the mythical Hades (Ignacy Chiger: "The first time we went to Poltva River gave us an eerie feeling of being lost in an underground world, similar to the time when Orpheus descended to Hades"355). There is another reference to the social exclusion of the hiding Jews. There is no place for them in the world "on the surface", the world of the living, so they are looking for it under the ground, where, perhaps, the cruel rule and laws of this inhospitable reality have no power.

Hiding places which were not necessarily located underground, but which were tight, lacking air and light, were also called graves. Those two elements are especially making one think about a grave. An account by Leokadia Silverstein from the Warsaw Ghetto can be an example of that: "It was dark in our stash. It was lit by a faint ray of light from a window located just under the ceiling and almost completely covered with bags of sand. We saw the specks of dust dancing in the air in this streak of light. Our faces had a strange pale aura to them. One could think that a group of people was buried alive here. The lack of air was especially tormenting"356. Dawid Fogelman, "Robinson Crusoe" who lived in a bunker in Warsaw would often use the grave metaphor: "We are buried alive" (when a grenade fell into the bunker and buried the entrance), "after five weeks in that grave..." 357 . Cheim Icel Goldstein used phrases connected with a grave

353 M. Lewycka, Zarys dziejów traktora po ukraińsku [A Short History of Tractors in Ukrainian], Warsaw 2006, pp. 244-245.

354 AJHI, 302/103, Journal of Irena Grocher.

355 AYV, 033/3059, Ignacy Chiger, Świat w mroku. Przebieg zmagań o życie [World of Darkness. Course of Struggle for Survival].

356 L. Silverstein, Tak właśnie było... [That's What Happened], p. 155.

357 D. Fogelman, Pamiętnik... [A Journal...]. 
twice. This is how he summed up the first moment spent in a bunker in ruins of Franciszkańska Street in Warsaw at the end of the Warsaw Uprising: "We felt that the last tie with the world was severed, we fell into the abyss. We felt tremendous yearning, even for those who were now chased with butts of German riffles; at least they feel that they are alive and we are buried alive here" ${ }^{358}$. When the home in the basement of which the bunker was dug caved in, the hiding people were in despair. The arising metaphor of a grave is a premonition of death. "We're doomed... there's no way out... we are in a grave... we'll die here and nobody will even know it... [...] We all envisioned ourselves growing ever weaker, with no food, no water, shivering in creeping agony amongst the sewer rats, which will start eating a man before he draws his last breath..."359. Digging up a crevice that let in the fresh air and let the people see the sky was their salvation. Landsberg, when his caregivers lock up and cover the hiding place after delivering the food, notes: "We hear hollow bangs of beetroots they use to cover the board. We think that this is the sound of dirt falling at the lid of our coffin" ${ }^{360}$. The sensation of being in a grave is imposed here by the fact that somebody else is closing the hiding place from the outside. Man - like a body in a coffin - remains inside, passive, motionless, locked. There is no way out from the grave. We have to note here, that similar associations came to minds of the residents of the Warsaw Ghetto when a wall was being built around the shut-down district. Wanda Lubelska wrote these words before the ghetto got closed: "They want to wall us in alive in here" 361 . We can imagine the string of ever tighter spaces for the Jews: the ghetto closed off with a wall, tightness of a hiding place, and, in the end, the inevitable prospect of a grave.

Henryk Neugebauer described a hiding place in the Sosnowiec Ghetto. People were one by one leaving a basement covered with a wardrobe, not being able to take the tension and lack of air anymore ("we were practically poisoned with our own exhausts"). Finally, when a hiding place is emptied out, despite reasonable basis to be glad ("It was simple. The less people were in the basement, the better it was for the ones left in there"), the people left feel even more uneasy: "Our basement became a real family tomb - only four of us were left, me and 'my' women: Basia, Róża and their mother". Comparison with a tomb comes to mind because the starved and parched people find it harder and harder to believe that they will

358 C.I. Goldstein, Bunkier... [Bunker...], p. 10.

359 Ibid., p. 14.

360 AYV, 033/1099, Journal of M. Landsberg.

361 Dziesięć listów $\mathrm{z}$ warszawskiego getta [Ten Letters from Warsaw Ghetto], ed. Z. Borzymińska, “Biuletyn ŻIH” 1984, No. 129-130. 
come out of it alive. With no prospect of resupplying or any improvement of the situation, they would sometimes think: "we would be better off dead than suffering like that day in, day out"362. Guta Szynowłoga-Trokenheim has also called her hiding place a tomb (she even entitled her memoire as Życie w grobowcu [Life in a Tomb]). In fact, it was a small cellar reinforced with gravestones. To get some air, they would come out of there to a cemetery. "I would look around the cemetery and ask God: Where are we, me and my child? Is it life or death? We are surrounded by graves and headstones, we live in a prison of a tomb"363.

Sometimes a hiding place would literally become a grave. In the beginning, it was something like a morgue: when somebody died (or was killed) in a hiding place, the others were trying to find a solution to that situation, somehow get rid of the body. However, for the time being, they were forced to keep it in. It was also a mysterious tomb, when it turned out that there was already a body of a stranger or a friend in a place selected to be a hiding place. It was also simply a grave, when underneath "the floor" of a dugout or a basement a person who died in a hiding place was really buried. From that moment on the people who stayed alive were stuck staying guard at the grave, they were sentenced to coexistence. The last, extreme example of the proximity of the motif of a grave and the phenomenon of a hiding place, are the cases I wrote about in Chapter 1 - living people hiding in piles of dead bodies during executions.

The first situation can be illustrated by Landsberg's thought: "Me and Rudy often think that in case of a serious illness we are almost sentenced to death, as, naturally, there's no way we can get any medical help in our conditions. Rudy claims that a corpse is incredibly stiff and if one of us were to die, we wouldn't be able to pull the dead man out through the hatch. We'd have to cut the body and deliver it upstairs piece by piece. A pretty prospect for a dead living man"364. Wilhelm Dichter reconstructed the reasoning of the terminally ill father who wanted to leave a shared hiding place before he died: "Father said that she [mother] mustn't shatter lives - the child's and her own. 'Just accept that I'm dying. What would you do with my body? I have to go back to the barracks"'365.

A sudden "rendezvous with a dead man" was a common experience for the "Robinson Crusoes" living in the deserted city. Leokadia Silverstein found a dead body not directly in a hiding place, but in a basement of one of the tenements of

362 Ibid., pp. 109-111.

363 G. Szynowłoga-Trokenheim, Życie w grobowcu [Life in a Tomb], Warsaw 2002, p. 75.

364 AYV, 033/1099, Journal of M. Landsberg.

365 W. Dichter, Koń Pana Boga. Szkoła bezbożników [God's Horse. The Atheists' School], Cracow 2003, p. 42. 
the Warsaw Ghetto where she went looking for food. "The flame twinkled and we saw a terrifying sight. We just stood there, frozen. Rotting human corpse was lying there in a crummy basement kip. Startled rats were hiding in dark corners. [...] I was very frightened, but I thought: 'The dead are here? And so what? What can they do? It's the living that you should be scared of'. We cooled off enough to take care of the jar of flour that we saw next to the body. Marysia went up to the dead man, took the jar from the bench and gave it to me. [...] I kept it together while still in the basement, but then, when we were walking up the stairs, I felt that I couldn't take it anymore. Why is Marysia walking so slowly? - I was quietly getting angry. I couldn't shake the feeling that the dead man is looking at us reproachfully for taking away his food"366. Dawid Fogelman has partaken in a similar event, yet he wrote about it unemotionally: "We wanted to get in the staircase, but there was a charred dead body there. At first, we pull back, but, well, we have to go, can't do anything about it"367. Chaim Icel Goldstein and his companion, Daniel, attempted to bury bodies found during their expedition to the next door's basement: "Without saying a word, we both took a piece of wood and started showing the human limbs deeper into the dirt floor and shoveling the dirt. That was all that we could do for them..." ${ }^{368}$

The third situation - living literally "on" a grave, was probably the most difficult and not many people were able to psychically handle such a burden. Władka Meed describes a situation like that: a small group of people was hiding in a wooden home of Poles, in Warsaw at 53 Radzymińska Street. Four people were occupying one small room, which was permanently locked. Due to constantly deteriorating situation of the hiding people (no money, conflict with their hostess), one of the residents of the hiding place, Klara Hechtman, spiraled into insanity. Because she was screaming in Yiddish during her fits, she was a threat for the whole hideout. Meed wrote: "After some time I found out that the other residents of the home asked the son of the hosts to poison Klara Hechtman. She was buried under the clay floor in the same room where the Jews were hiding. Soon it turned out that they are unable to stay there any longer. [...] You could see that, soon enough, the three remaining people will have a share of the same madness that doomed their companion"369.

366 L. Silverstein, Tak właśnie było... [That’s What Happened], p. 177.

367 D. Fogelman, Pamiętnik... [Journal...].

368 C.I. Goldstein, Bunkier... [Bunker], p. 39.

369 W. Meed, Po obu stronach... [On Both Sides...], pp. 234-235. 
A dead man's body arouses dread. Ryszard Witold Gryglewski calls the death a "breaking point" and goes on to say: "From the time of demise a human being goes from being 'a living person' to 'a dead person"” 370 . The body of a dead person is seen as alien. Its transformations are especially appalling: "Rotting of the body, late and absolute sign of death, begins the most dramatic phase of the thanatotic process, becoming a specific phenomenon, attracting the most inexpugnable phantasms"371. Authors such as Anna Wieczorkiewicz ${ }^{372}$ and Alain Corbin ${ }^{373}$ wrote on the subject of the harrowing reek of the rotting body.

A funeral is a ritual of taming the death and the emotions it induces, easing the transition of the deceased to the next world ${ }^{374}$. Gryglewski continued: "For the dead man [...] is a serious problem, which needs to be efficiently dealt with on the cultural ground. The corpse, despite the deformations it goes through, is a constant reminder of the deceased person. The departed cannot, however, remain in a community under the same conditions as a living person. He has to go, even if not all ties have to be severed. This is why new relations have to be established. This is what the rituals (ceremonies) of disconnection are for" ${ }^{\prime 375}$.

Therefore, an unburied body is the most frightening, as it is in a liminal period - already excluded from the world of the living, but not yet included to the world of the dead. It is hard to classify, as at the same time it is a human being and a thing. According to Thomas, a corpse is "impure and barred" ${ }^{376}$, "outside of the discourse" 377 , so the living protect themselves from a contact with it, which would make them at risk of contamination. Aside from the cultural taboo, the medical harmfulness of the corpses is also relevant: their toxicity, ptomaine,

370 R.W. Gryglewski, Mumifikacja ciała ludzkiego w świetle historii obyczajów i nauk medycznych [Mumification of Human Body in History of Customs and Medical Sciences], Cracow 2005, p. 57.

371 L.V. Thomas, Trup. Od biologii do antropologii [The Corpse. From Biology to Anthropology], Łódź 1991, p. 19.

372 A. Wieczorkiewicz, Muzeum ludzkich ciał [Museum of Human Bodies], Gdańsk 2000.

373 A. Corbin, We władzy wstrętu. Społeczna historia poznania przez węch. Od odrazy do snu ekologicznego [The Foul and the Fragrant: Odor and the French Social Imagination], Warsaw 1998.

374 A. van Gennep, Rites of Passage, M.B. Vizedom, G.L. Caffee, London and Henley 1977.

375 R.W. Gryglewski, Mumifikacja ciała ludzkiego... [Mumification of Human Body...], p. 59.

376 L.V. Thomas, Trup... [The Corpse...], p. 85.

377 Ibid., p. 52. 
accumulation of gases and liquids from decomposition in a grave, possibility of contamination of groundwater.

Pushing this dreadful "human thing" away from oneself can be done by destroying the body (cremation), abandoning it (in a swamp, in the wilderness), hiding it (burial in the ground) or by halting the putrefaction (mummification). Digging a grave precedes giving the body to the ground. Mircea Eliade links this process to agriculture ${ }^{378}$. One of the oldest concepts of what happens after we die includes comparing the dead to a seed and the grave to a fertile soil that will give new life. The vision of Mother Earth derivates from this concept: the grave is an abdomen, where the deceased is hidden like an unborn child. In this scenario, the cycle and the ritual are completed, the reality, which was disrupted by death, regains equilibrium.

Jacek Leociak wrote: "Contemporary western culture is characterized by an increased tabooing of death. [...] There is even a more restrictive taboo of the corpse ${ }^{379}$. Nevertheless, during the Shoah, the residents of ghettos were getting used to sites of corpses disrespectfully abandoned in the streets for months. Funerals slowly became signs of the previous, "civilized" era, and the people were witnessing devalued, increasingly massive death. Gruesome images, which in fact have their counterparts in European culture ${ }^{380}$, became an everyday occurrence in the wartime reality. They were also present in the texts of the testimonies, the form of which were allowing for reification of the dead and stripping the death of dignity.

Therefore, we can assume that, under the pressure of the reality, the cultural taboos connected with corpses and graves lost their power. "The natural distance between the life and death is broken"381. To save life it was then possible to hide in a grave, to discuss what to do with a body of a dead companion, to get across a dead body that was in a way to a desired basement stacked with provisions... But even in those morbid times there was still a place for taboos. It is impossible to have a funeral in a hiding place; one cannot earmark a separate place for a cemetery. This apparent confusion of orders, mixing of fundamentally separate spaces, was still causing high level of psychological discomfort, even for people, who have seen a lot and were able to take a lot as well. As long as everything occurred on a level of a discourse, the situation was easier to control. Describing a

378 M. Eliade, A History of Religious Ideas, Chicago 1981.

379 J. Leociak, Tekst... [Text], p. 216.

380 P. Ariès, Images of Man and Death, Cambridge 1985; J. Delumeau, Sin and Fear: The Emergence of the Western Guilt Culture, $13^{\text {th }}-18^{\text {th }}$ Centuries, New York 1991.

381 J. Leociak, Tekst... [Text], p. 218. 
hiding place as a grave was just another example of gruesome motifs present in the texts of the testimonies. However, an actual dead body and a real-life grave were not so susceptible to word spells.

\section{Metacategory - prison}

Prison is a separate and an incredibly capacious metaphor of a hiding place. We can call it a metacategory, as its semantic scope and analytical potential are bigger than of the models proposed above. In a way, one can describe every locked hiding place through the metaphor of a prison. This is why I shall dedicate more space to this concept. The hiding people often use it in their texts and testimonies to describe their situation by relating to the most basic associations. The first ones are confinement and constraint - prison as a place that one cannot leave. Additionally, there was the monotony of endless days, crummy surroundings, meaning limited stimuli, often being separated from the loved ones, company of random people. We can therefore perceive the prison as a metaphor of a hiding place from two levels. The first one is the perspective of the authors of the testimonies, who, when describing a strange reality which was non-yielding to narration, draw on stereotypes to clarify the things that they cannot describe in a different fashion. The second level is an analysis of an abstract model of a prison, not only based on the texts of the hiding people, but also the prisoners - from completely different contexts and a different reality, but presenting the essence of prison, its "ideal type". The second level is included into my deliberations for the same purpose that guided the hiding people to use the metaphor of prison - to get to the gist of something that is so hard to describe directly. I shall try to look for features in the anatomy of prison that make the writers inclined to use this metaphor, and, in the context of those features, describe a few aspects of hiding place's space.

In the words of Andrzej Stasiuk, an archetypical prison is "an ambivalent, disgusting and obscene" thing, characterized by "filth, stench, debasement, loneliness and a curse" 382 . The model of a prison evolved side by side with the history of humanity, to get from a waiting area before the capital punishment and a permanent place of execution to a punishment in itself. Leaving aside its history and details of its evolution ${ }^{383}$, I shall analyze the model of (fairly) modern times, let us say - of the $20^{\text {th }}$ century. I do not mean to compare a hiding place to a specific prison, as in various times and places the prisons had a variety of

382 A. Stasiuk, Fado [Fado], Wołowiec 2006, p. 101.

383 See M. Foucault, Nadzorować i karać [Discipline and Punish], Warsaw 1998; M. Ciosek, Psychologia sądowa i penitencjarna [Forensic Psychology], Warsaw 2001. 
forms. However, in the prisons of the Soviet Union, Poland, Romania or Albania, or even English Reading, we can see some common characteristics, which will allow us to isolate an "ideal model" usable for an analysis. It is an abstract, a personification of prison, which allows us to use data from a plethora of testimonies, various dates and countries.

It does not seem to be very helpful within the context of various types of prisons to present it solely as a place for common criminals, where prison cant and violence reign. The model of a prison from totalitarian times seems to be more appropriate here - as a place where the political prisoners are separated from the world, i.e. the people who somehow do not fit the society imagined by the authorities. These people have not, according to common sense, done anything wrong. They are guilty of being who they are, but also of what they are thinking and doing against the will of the authorities. The sole desire for freedom is sentencing them to captivity. Similarly, the Jews in occupied Poland ruled by the totalitarian authorities, not even desiring freedom, but simply a life, according to the logic of the system, were sentencing themselves to live "under the surface", to go to the prison of a hiding place. Majority of the thoughts on the subject of a prison quoted here actually comes from texts by political prisoners, dissidents living (and serving time in prison) in countries of Eastern Europe in the second half of the $20^{\text {th }}$ century.

Those prisons are no longer the cold, dark dungeons known in the pre-modern times, but they are a far cry from contemporary prisons, where, to exaggerate a little, the inmates have a TV-set and a gym at their disposal in a penitentiary institution. Those prisons are, however, not free from suffering and fear. A man locked in there is exposed to physical inconveniences, which, in a long run, become a torture. He is frightened, because the law, and especially the human rights, cannot penetrate the murky structure of this institution. Respect for the dignity of the prisoners is not a basic concern of the prison personnel and a convict cannot necessarily rely on the courts to treat him fairly. A prison of the totalitarian times was a dark well, where a human being could disappear irrecoverably and without a trace. He could, however, also serve the sentence and just get out of there, and return to his life in the outside world. This is also bringing us back to a wartime hiding place, which was not giving any guarantees (and was certainly not protecting people from violence, suffering and injustice), but was giving people a chance to survive for some time in relatively peaceful and quiet conditions. Of course, some characteristics of ordinary prisons fit my model due to their universality. This is why I draw upon the findings of Marek M. Kamiński or Paweł Moczydłowski, who were exploring the world of Polish prisons in the 1980s. The data they have collected and the notes on the essence of prisons are 
excellently complementing the images remembered by political prisoners, for the physical aspects of the places are similar. However, the specific character of the inmates' experiences and the depths of their afterthoughts are important here as well. I believe that an image of a "political" prison, the one the authors of the memoirs saw, is the closest to the abstract model of a prison I am looking for, the one that an analysis of the space of a hiding place is bringing to mind.

I shall also note that the metaphor of prison is present in Jewish testimonies in another context as well. This association was obvious for the people located in ghettos, who, even before the time of being imprisoned in the hiding places came, were painfully experiencing the isolation, oppression, limited space and the control. Those feelings were exacerbated by the walls that separated some of the ghettos (or by barbed-wire or picket fences, etc.). I shall use the words of Wanda Lubelska as an example here, who wrote her friend from the Warsaw Ghetto in December of 1940: "Walls everywhere, police, guards, terrible prison, everything combined, and that feeling of being in a prison do horrible things to a human mind"384. In a broader sense the metaphor of a prison can be extended to the whole of occupation, stressing its features such as its oppressive nature and the sense of being limited.

A prison and a hiding place are constituted by the phrase: "do not". Do not enter, do not act in a certain way. Do not do many things, or a hiding place will stop being one (it will be seen, heard, uncovered, and its residents will die), and a prison will stop being a prison (without discipline and a system of prohibitions the prisoners will scurry into the world and the sentence will not be served). A prohibition is therefore a sine qua non condition for the existence of those two places. Both determine themselves through negation, as a reverse of the normal life. Depending on what is prohibited there, what is the person entering such a place deprived of, we can tell if this is a hiding place, or a prison.

In Polish legal jargon, a prison sentence is referred to as "a penalty of depravation of liberty". Imprisoned people have less power over self than they would wish to have. First of all, they cannot leave a prison, but are instead sentenced to stay there for as long as it was adjudged. They have no choice and cannot decide for themselves - they are condemned to conditions, schedule and rules of the prison that were designed for them by somebody else. They can only use a space that was carefully allocated for them; they can only perform some particular activities. If they wish to do something else, they take a risk of being punished;

384 Dziesięć listów... [Ten Letters...]. 
they can try to perform some forbidden activities, but that requires wit, courage, and help of inmates or bribing the guards.

In a hiding place, much like in a prison, people are locked up, deprived of their liberty. They cannot leave as well and are not allowed to do things that free people do. The essence of this limitation, however, is different. Hiding people are not guarded by other people or limited by walls. They are hostages of the situation in which they are. Their freedom is limited by the awareness of what is awaiting them on the outside, by the pressure from other people hiding and by physical conditions of a hideout. After some time, a situation of hiding causes people to become passive, the hiding place appears to be incapacitating the people inside, depriving them of a will to decide anything. Normally innocent elements of the space acquire different meanings. Thoughts on the subject can be found e.g. in texts by Chaim Icel Goldstein, who wrote: "We were ceaselessly watching the exit of the hiding place, as if there was some invisible guard there, who has our fate in his hands, while we can only passively await whatever it is that he decides to do with us. - I was watching the door in a similar way at my dear old lady's place that was the name given by Ignac to a woman, who was hiding him. - For many reasons, it was my biggest enemy... Sometimes I thought that gunmen will barge in through that door and drag me out of the hiding place along with my old lady. At the same time watching that door was awfully tormenting for me. Nobody was guarding it and all it took was to open it to get outside, to freedom... But, mind you - you can't! sometimes, in the evenings, when it was so humid in the room, that I couldn't catch my breath, I would look at the door and get awfully tempted to open it and breath in at least a bit of clean air... Chaim, you were in a camp, you saw the barbed-wire fences, SS-men, kapo, saw the people who were keeping you prisoner, the ones who were torturing you... But me? I thought that I was torturing myself. When I heard people walking outside the window, children playing, women laughing, it seemed to me that I'd tied up myself and I was keeping myself captive"385.

Imprisonment is a punishment, it is in fact a tool of the social system established just for that purpose - to punish somebody for something in an orderly manner under state control. But is a hiding place a punishment? It is, in a way, just like a ghetto or a camp were a punishment as well. Germans are indirectly throwing Jews into hiding places, prohibiting them from being anywhere else. They are forcing them to build hiding places or look for them and are not giving them any choice. Hence a hiding place is a product of the system, which convicted the Jews

385 C.I. Goldstein, Bunkier... [Bunker], p. 160. 
for the crimes made up by Nazis. Components of that punishment include denying people normal life, taking away their homes, jobs, position in a society, causing impoverishment, threatening with death, separating them from their loved ones, making them uncertain about their future... A hiding place is one of the options of the destiny that befalls a Jew, a place where people experience some bad things, but avoid other. In a way people remove themselves from the mainstream, want to wait something out, and pretend not to exist, cheat the fate.

Imprisonment is rarely voluntary. People usually go to prison lead by guards, handcuffed, not willingly. There are, however, people, who turn themselves in to confess to the crimes they did or did not commit. For some reason, they want to go to prison. It can stem from higher reasons - guilty conscience, remorse, or simple calculation, like for the homeless people, who hope for a roof over their heads and food in a prison. The situation is more complicated in case of a hiding place. Nobody is hiding because they really want to get into a bunker, basement, a walled in room. However, in particular situations, an alternative of a hiding place is death. Then the choice is only apparent. A hideout is a chance prompted by a survival instinct. It is true both for a temporary hiding place, found when faced with imminent threat quickly, as if unwittingly, and for a bunker that had been being prepared for a long time. One does not go into such a shelter because it seems to be the best place to be. It is the only option, if one wants to live.

It is worth noting that a prison and a hiding place are two sides of the same reality in a totalitarian state. For people, who were for some reasons of interest for law enforcement authorities, hiding oneself was often the only alternative to prison. Therefore, some would willingly limit their freedom by "locking themselves up", lying low in a safe place, not letting the authorities to limit that freedom in their own way.

A hiding place is also a place of isolation that is compulsory as a consequence of the acts committed. Staying in a hiding place is in itself punishable by a paramount punishment - death. Just like being anywhere else for a Jew... And here is the fundamental difference between a prison and a hiding place, which is based on the element of secrecy, illegality, a wish to disappear from the face of the Earth, which constituted a hiding place. Staying in a prison is, in turn, legal; it is in fact an expression and culmination of the state's legalism. After all, it is a place proper and intended for a specific category of people, connected with hardships and often suffering. But since it is the system that determines it for the prisoners, they do not have to hide their existence there.

However, from some perspective, a hiding place can be treated as a reward in the sea of punishments - a patch of the world where the cruel outside rules do not apply. A haven on a dangerous route. A good hiding place is a treasure worth 
every penny. It simply means life, so it can be seen as the most valuable reward in the given conditions. When going into a hiding place, people make a sort of a deal - there is no way out, no alternative, so we accept the place we get, but we do so in hope of surviving in this manner. A stay in a hiding place is connected with a whole array of hardships and suffering, but they are of inferior nature when compared to the goal. In return for all the limitations stemming from being in a hiding place, people expect the ultimate reward - salvation. Without that hope and anticipation, the deal would not make any sense and there would be no place for a hideout itself.

Captivity in a prison does not only mean limited freedom of actions. The system's objective is also to break the inmates, to take away their dignity. This is characteristic of totalitarian prisons. Often the discipline in a prison was enough, along with interrogation and losing hope for freedom, but there were also more cruel methods. Adam Bodor wrote about Organization of Prisoners with Communist Beliefs inspired by the authorities in a Romanian prison where he was sent in the 50s: "They extorted confessions with torture [...], to forward them to Securitate, but the final goal of their procedures was to eliminate individuals. Tortures consisting of various stages lasted until the chosen person completely broken down, dismissed his past, family, principles, faith, i.e. until the moment when he was - as they called it - reeducated [...]. Then the recent victim was trusted with taking care of reeducating one of the inmates [...]. The feeling of simultaneously being the executioner and a victim was causing a complete personality breakdown, decline of any solidarity, and probably even capacity for moral assessment" ${ }^{\prime 386}$.

Still, both prison and a hiding place can become spaces of freedom. Karolina Lanckorońska, who was sent to the Stanisławów prison by the Gestapo, despite her fear and being exhausted from the interrogations, was able to maintain calm and control over her thoughts and actions over the whole time she was imprisoned. She stayed optimistic the whole time, rating her living conditions "superb", the food "tolerable" and the time in solitude - even relaxing. Lanckorońska wrote: "Violently dragged away from the everyday life, from everyday tasks that used to absorb me completely, I, in a way, went through something probably similar to a sudden serious illness. I have never been sick and I knew I was lacking a lot in my development because of that. This is why I have decided to use this new situation to gather my strength, feelings, thoughts and will"387. Even being

386 A. Bodor, Zapach więzienia [The Smell of Prison], Wołowiec 2004, p. 91.

387 K. Lanckorońska, Wspomnienia wojenne [Wartime Memories], Cracow 2001, p. 157. 
confined in the darkness was met with calm on her side: "I stayed there in the dark, but I was alone and it was nice. [...] I soon got used to the new situation and found a pleasant way to spend the day. Every day I was traveling in my mind to one of the great European galleries to see the paintings. [...] I was once again in the world that used to be mine and I was fine" ${ }^{\text {"388 }}$. In this case the space of freedom was in her imagination, in the memory of past life, in the opulence of the world, that she was able to experience before. Deteriorating conditions, hunger, and even the thought of the probably approaching execution did not change the Lenckorońska's state of mind too much. When the guard called her name, she was, as she wrote "completely certain of death and calm"389. Vladimir Bukovsky stayed free in spirit in a soviet prison, where he would constantly organize actions among his inmates, read books, gather strength for the next short interval of freedom. He was somehow able to insert the periodically recurring prison sentences into his life plan and not to lose spirit, dignity, and a will to fight ${ }^{390}$.

Similarly, it is possible to keep some part of personal freedom in a hiding place. One of the ways to achieve that was writing. There are extensive analyses on the topic of documents of the Holocaust times ${ }^{391}$. I will only limit myself here to signal the fact that the act of writing in extremely harsh conditions of a hiding place is an attempt to go beyond the framework imposed by a hideout. By making a creative effort a hiding place becomes something more than a compartment for a body that has to be kept alive by having its basic needs satisfied. Along with the decision to write, a sort of spiritual dimension opens up in there. Writing can be seen as a luxury, but for the countless hiding people it was in a way a necessity, since they found the strength to do it. Many texts were created in hiding. Let us quote Stefan Ernest, who wrote the following words on $28^{\text {th }}$ May 1943: "Even though I clearly see that, in the system of my personal conditions, I am a very last of those 'candidates for survival', that due to my 'appearance', means, physical and psychological strength, I have no chance in this final battle on this side - I write. [...] I am hiding in a dungeon, with no air, without sufficient and regular nutrition, without adequate sanitation, with no prospect of changing those vegetative conditions, which make every living hour precious. I distinctly feel that I'm getting weaker, I'm starting to suffocate... Fighting for personal salvation becomes hopeless... that is on this side of the wall. But it does not matter, for

388 Ibid., pp. 161-162.

389 Ibid., p. 172.

390 V. Bukovsky, I powraca wiatr... [And the Wind Returns...], Cracow 1999.

391 See J. Leociak, Tekst... [Text]. 
I can finish my report and I believe that it will reach the public in due time"392. The author of those words wrote down 306 pages in a hiding place. His text is raw, precise, ruthless. He does not talk about himself much, he rather wishes to give testimony from the wartime. Thereby, by devoting himself to the task and the mission, he carves out a space of freedom from his hiding place - freedom of speech and untamed assessments.

When we look at the issue more broadly, the space of freedom in a hiding place is determined by almost any activity that is more than just sheer biology. Playing cards, friendly conversations, human kindness, developing feelings, reading, interest in news from the frontlines, political discussions, care about personal hygiene - those are all expressions of a will to live and of preserving one's dignity despite the circumstances. Characters from Chaim Icel Goldstein's memoires would even joke about unpleasant situations, such as struggling with wretched flies: "As you can see, there is no disaster that you can't laugh about, which was definitely precious to us. We needed the laughter almost as much as we needed the food and water" ${ }^{393}$. A specific kind of hiding places - civilian camps by partisan divisions - allowed developing a vast array of behaviors that made the stay in a forest highly akin to normal life. Such camps were not only economically self-sufficient, but people of the camps were also concerned with such cultural activities as running a school, theatre or a choir (e.g. in Hersz Posesorski's division $)^{394}$. Aleksandra Bańkowska, when writing about woodland hiding places, mentioned another area of life associated with freedom - religion. "Accounts describing religiousness of the hiding people are very rare, but worth noting. In two cases families who lived as beggars were still trying to observe the basic rules of kashrut. In one case the protagonist observes Sabbath. Jews who pray regularly appear several times. We know about a synagogue that was functioning in Bielski's camp. Marek Lessing recalled a ritual funeral of a comrade murdered during a manhunt" 395 . Religious activity was present in other testimonies as well - I will only cite the memories of Sara Zyskind, who was hiding in an abandoned house with her father in the Łódź ghetto. They would go there every day from their own apartment with food supplies. One day "father also took a prayer shawl, phylacteries and the Book of Psalms"396. Not bringing up any more examples, but continuing this line of thought, it can be concluded that a hiding

392 P. Ernest, O wojnie... [About the War...], pp. 353-354.

393 C.I. Goldstein, Bunkier... [Bunker...], p. 64.

394 See AJHI, 301/563.

395 A. Bańkowska, Las jako miejsce... [Forest as a Place...], p. 57.

396 P. Zyskind, Skradzione... [Stolen...], p. 86. 
place itself is a space of freedom. It was limited - as there are no enclaves of absolute freedom in a society - but was probably the only one left in the occupied Poland. Even though many things are prohibited in a hiding place, the life goes on right inside of it - even if it is so hard that some would rather call it vegetation.

Paweł Moczydłowski wrote that "The institution of prison primarily serves the implementation of control functions of a social system" 397 . A hiding place, however, is not an institution. If it fits into the social system, it is a part of its grey area. As I wrote before, a hiding place is rather a loophole in the system, a search for an illegal, uncontrolled space for illegal people. Similarities between an institution of prison and a hiding place can be, however, found in secrecy, which is an aspect of both those places. A hiding place is secretive by nature. It would be ideal if nobody knew it existed or what mechanisms are behind its functioning. An institution of prison is officially visible, but its inner mechanisms are classified. Just like other institutions at the authorities' disposal (e.g. military or special forces), a prison is a place covered with professional secrecy, excluded from social control, literally and figuratively isolated from the world ${ }^{398}$. Totalitarian state prisons can be compared to a black hole - people who were sent there (often disregarding official procedures, without trials and sentences) could disappear off the radar of their loved ones for a long time, even forever, and getting any information from the administration at least on their whereabouts was impossible. Another aspect of the secrecy of a prison is the subculture developed inside (so called second life), as a natural self-defense against pervasive control over the life of the prisoners. A prison has countless hiding places, where people would hide e.g. prohibited items, letters, books. Inmates create an informal structure, patterns of behavior, strict procedures of transferring information. Thus, we can say that a prison is a secretive place. Moczydłowski presents an anatomy of a secret: "The thing about a secret is that it hides some state of affairs aimed against somebody or something. Therefore, there is one or many 'addressees' whom the secret-holder would not wish the information about a particular state of affairs to reach. 'Addressees', for many reasons, known to the secret-holders, could react in a way that the perpetrators are afraid of and this is why they are keeping the source of those concerns in secret. They can share that secret only with the ones

397 P. Moczydłowski, O sposobach wglądu w sekrety stosunków międzyludzkich. Przypadek insty $\neg$ tucji totalnych [On the Ways of Looking into Secrets of Interpersonal Relations. Case of Total Institutions], "Kultura i Społeczeństwo" [Culture and Society] 1990, No. 1 .

398 Ibid. 
they trust, i.e. with whom they share other secrets as well" ${ }^{399}$. In a prison those wrong addressees include the wardens and indirectly the ones who are not inside the group of the perpetrators, the "snitches". In a hiding place a collection of unwanted addressees is vast, covers nearly the whole outside world, excluding potential helping people, the hosts. Even the residents of other hiding places, who, in theory, have the same status, can become a part of the group of unwanted addressees due to fear of treason. Needless to say, the stake of the secret getting out is incomparable in those two cases.

In principle, a prison is the only appropriate place for a convict. It is a place that person is ascribed to, he or she has no right to be outside of a prison, unless an appropriate pardon has been issued. An escaped convict is in danger, much like the Jews who abandoned a hiding place. However, a convict (naturally depending on the political system and context) is usually not risking death, but simply going back to the big house or possibly a harsher punishment. A hiding person, just like a prisoner, is excluded from the society, stigmatized just by being in a particular place, by hiding. People in a hiding place are, for some reason, considered bad, damaged, dangerous. But it is easier for an escaped convict to survive than it is for a Jew without a hiding place. The oppressive nature of the situation in the outside world is hard to compare in those two cases.

I think the most important thing in finding an appropriate model of prison for an analysis of a hiding place is the emphasis on negative experiences, emotions, changes in the psyche connected with confinement. A prison is a cursed, despised, shameful place that people are reluctant to reminisce about. With an exception of desperately poor people who prefer to survive a winter in a prison, where they can count on a roof over their heads and food, rather than freeze to death on the streets, probably nobody wants to go there willingly. Why is that? To describe it precisely I shall invoke findings of criminology and psychology, which describe prison in an exhausting manner. Mieczysław Ciosek ${ }^{400}$ presented isolation of a prison as a difficult situation in a life of a human being. Isolation is defined as a system of relations between a human being and such an enclosed environment which, by means of physical and social barriers, causes severing ties between a person and that person's previous environment. Erving Goffman's definition of total institutions ${ }^{401}$ can be useful to describe a situation of isolation.

399 Ibid.

400 M. Ciosek, Psychologia sądowa... [Forensic Psychology...].

401 E. Goffman, Charakterystyka instytucji totalnych [Characteristic of Total Institutions], in: Elementy teorii socjologicznych [Elements of Sociological Theories], eds. W. Derczyński, A. Jasińska-Kania, J. Szacki, Warsaw 1975. 
It assumes that in places like that the typically separate areas of life are merged: sleep, play, and work; all human activity is planned and takes place publically, there is no privacy. Aside from prisons, there are other total institutions in a society: hospitals, various camps, military, submarines etc. They are all characterized by some features, which are listed by Ciosek, who quotes Ellenberger. Inside of them there is a physical barrier separating a closed institution from an open society. By crossing it an individual carries out experiences, which make future adaptation easier or harder. The barrier makes the movement impossible in both directions: entering and exiting, minimizing contact with the outside world. A human being is to spend some time in isolation. That period is or is not specified. When that time passes, the return to the outside world shall take place. It is impeded by the experience gained during isolation.

A prison, in its functional aspect, limits activities of the inmates, controls them and has an almost total power over them. People are "doing time" in prison. This idiom suggests that this is all that people do inside, it emphasizes the lack of motion typical in this situation. The defining characteristic of a prison is deprivation of the inmates of freedom of movement, action and contact with others. Secondly, a prison reduces material and service goods of all the inmates to an identical level. Everybody eats the same things, dresses in the same uniforms, has limited consumer opportunities. It is also consistent with reduction of living conditions, lack of own space that one would organize by oneself, with its furniture, appliances and conveniences. The stress levels connected with those limitations depend on the conditions that an inmate had on the outside. Additionally, a prisoner is stripped of his autonomy, even the smallest mundane things are decided for him. He is not regarded to as a sovereign entity, but as a "passive and powerless object impacted by others - also due to the fact that he is not informed about the reasons of particular decisions"

This is why apathy is common among prisoners. It is a defense mechanism. "People can get used to anything and slowly grow a kind of thick, callous shell. One has to learn not to notice anything, not to think about home, not to wait for freedom. And adapt to this life so that it passes you by. Everything that is happening becomes unreal and is instantly forgotten. I have gradually developed that indifference. I just could not get used to one thing. In the evenings, I could distinctly hear the tires of Leningrad's buses sliding on the tarmac outside of the fence, and that sound was like a shock to me. Suddenly everything around me

402 M. Ciosek, Psychologia sądowa... [Forensic Psychology...], p. 300. 
was becoming vivid and real, so much that it hurt. Nay, not every life is better than death" ${ }^{303}$.

Certainly, a hiding place can be also seen as a situation of isolation and a difficult situation. The level of stress experienced by the hiding people depends on many circumstances: context of the situation, location of a hiding place, expected threat, chance for an outside help, physical conditions inside. According to psychologists (Steven Hobfoll) ${ }^{404}$, the factors that cause extreme stress have the following characteristics: "they attack the most basic human values, such as life, shelter; they make extremely high demands that are impossible to meet by applying the already existing strategies of using the available resources; they often come without a warning [...]"405. Such factors emerge in boundary situations, such as an unexpected loss of the previous hiding place, a necessity to find an improvised hiding place in a situation of sudden danger, violent conflict of the people inside of a hideout, sudden outside threat. A prolonged stay even in a relatively safe hiding place causes a chronic stress typical for a situation of isolation. The main factors of such stress include: limitation of quantity and diversity of stimuli, available space, social contacts, lack of privacy and isolation from the group, and deprivation of needs.

Yet it is hard to classify a hiding place as a compulsory situation of isolation. As I wrote above, a hiding place is not voluntary in a sense that when given a free choice nobody would like to reside in there. People themselves make a decision to hide, but they decide under pressure, in a situation when the alternative is death. Thus, it is a false choice. One can, however, decide between various ways to survive (hideout, Aryan papers), between various hiding places, or even whether one will try to survive or not. There are testimonies describing people who, for various reasons, refused going into hiding or escaping a ghetto. Sometimes those were people who did not completely believe in the inevitability of death, but also people aware of the consequences of their choice. When it comes to the people who decided to stay in a hiding place, often the choice of a place occurred outside of their conscious choice (especially in case of temporary hiding places). However, there were instances when people voluntarily left a hiding place to look for a better alternative themselves. It could have had functional grounds, i.e. they were looking for a better, safer hiding place, but could have also been caused by severe discomfort experienced in the previous place. Such attempts to resolve a

403 V. Bukovsky, I powraca wiatr... [And the Wind Returns...], pp. 207-208.

404 Psychologia. Podręcznik akademicki [Psychology. Textbook], ed. J. Strelau, Gdańsk 2002.

405 Ibid., p. 474. 
stressful situation are impossible in case of prisoners, who are almost completely stripped from the ability to decide their fate. To escape the loathed space of a cell they could only commit suicide or resort to self-harm to be hospitalized. In the second case the action would probably only lead to a break in serving a sentence, after which the prisoner would return to the same place.

We have to note that whilst the institutionalized structure of prison is constant, rigid and highly empowered, a collective hiding place is an improvised community, which is unsustainable and easily destroyable, since there is no authority of power on its base, but rather a grassroots initiative, conflicting interests and dispute-inducing situation. A solitary hiding place, in turn, is similar to a single cell. A person inside is left alone with his thoughts, akin to a hermit. The substantial difference between a single cell or a hermitage and a hiding place is the sense of danger that is always accompanying the hiding person. Hermits and prisoners are free from that, and even if the space of a cell is a limitation to them, it is not, as in the case of a hiding person, the only possible space available in a hostile world.

Josif Brodski has aptly identified the most significant features of a prison. $\mathrm{He}$ wrote: "Speaking about enemies: you have the closest one in the cell, and it is the lack of space. A recipe for a prison is a lack of space balanced with surplus of time. A prison is a lack of alternative, and the past, distanced like in a telescope, drives one mad" 406 . Let us therefore try to take a closer look at the category I believe is key in both the space of a prison and of a hiding place by saying a few words on the category of time.

Both a hiding place and a prison are places of isolation, cut off from the real world and its plentiful opportunities. It is a sort of a waiting room, an intermission in the normal life course, place where people wait for something - the end of the sentence or war. Adam Bador was surprised to notice how rapid the process of isolation progresses: "As soon as after a few days the rhythm of the prison life, tightness of the hostile space marked by walls and bars were telling us that we are outside of time, in a world with its own rules [...]. Even for me, who knew this atmospheric town well, the whole area suddenly got detached from the geographical space, it landed outside of the real world and became completely unfamiliar to me. [...] Whatever was outside the walls was becoming more and more abstract and unreal. We came here confident, believing that it will all be

406 J. Brodski, Mniej niż ktoś [Less than Somebody. Essays], in: J. Brodski, Mniej niż ktoś. Eseje [Less than Somebody. Essays], Cracow 2006, p. 23. 
OK [...]. We've finally concluded that we're in a prison" ${ }^{307}$. In this respect, the situation of a hiding place is not that unambiguous. Residents of properly locked long-term hiding places, who never or almost never went outside, could have felt a similar "interruption of continuity" of space, detachment from the real world. However, majority of hiding places was connected with the outside world with a network of relations, ranging from sensorial experiences (looking through the cracks, listening to footsteps and other sounds), through contact with a helping person, and to going out by oneself, e.g. to get food. Therefore, on the one hand, a hiding place was a place dipped into another dimension, where the time moves quite differently and the normal life seems distant and unreal, and on the other hand, it is a part of this world, especially in case of close spatial proximity of other people (hiding places in urban areas, in tenements, at somebody's apartment, etc.). It sometimes happened that the outside world was literally at hand's reach - behind a thin wall - and yet distant, as this precise border of a thin wall was sacrosanct. The sensation of it being inaccessible was in a sense similar to the Bador's sense of isolation in a Romanian prison.

Monotony is a common feature of a prison and a long-term hiding place. A person inside one of those places starts to have trouble with time and stops thinking about it due to a high number of things to do every day. This is what Vladimir Bukovsky, a Russian dissident, wrote about that experience: "With complete isolation, lack of sunlight, the monotony of life, constant hunger and cold one gets into a strange state bordering on lethargy and hallucination. [...] Something strange starts happening with time. On the one hand, it races like crazy stunning your imagination in the process. That whole not-so-elaborate day schedule with mundane, steadily repeating events [...] fades into some drab yellow smudge, leaving behind no memories and no hook for consciousness. In the evening, when going to bed, a man cannot remember for the life of his what was it that he was doing the whole day, what did he have for breakfast or dinner. What is more, the following days are no different from one another, get cloudy in the memory and suddenly you notice, as if somebody poked you [...], that seven or even ten days had flown by. [...] And on the other hand, the same time is dragging astonishingly slowly: one could think that the whole year has passed - but no, that is still the same month that is stretching forever. At the same time, man gets awfully touchy when anything interrupts the monotony of his life. For example, suddenly, starting next month they take you out for a walk not after breakfast, but after dinner. You would think - that makes no difference, but

407 A. Bodor, Zapach... [The Smell...], p. 87. 
it makes you angry, almost mad. [...] Or you get a card from home, a pied one, and you keep staring at it like an idiot, nonstop [... ${ }^{3408}$.

The Jews hiding for months on end were experiencing the same thing. Leokadia Silverstein, when talking about her hiding place, was herself comparing the situation of the hiding people to the one of the prisoners. "The days were like two peas in a pod, lingering according to an old, well-known order: three meals a day, and between the meals - long hours of forced idleness. Waiting, waiting, and once again waiting. I think only the prisoners know how such idleness kills" ${ }^{409}$. The basic difference was that a prisoner has a crippling certainty of how the rest of his days is going to look like until the end of the sentence. There is a prison machine behind him, organizing everything for him, every day, lifting the responsibility for the everyday life off his shoulders. A hiding person is alone, between the complete responsibility for self (and sometimes others) and helplessness against the threats. The gap between what the situation requires and the capabilities creates tension and fear. Prisoners are also scared of many things - including violence from inmates or the personnel, theft of their possessions; they fear what they will find in their world after leaving the prison. However, it is hard to compare with a constant life-threatening situation experienced by the hiding people. For a prisoner, such a threat may only come in a form of fear of tortures during an interrogation or even an unexpected execution. Lili Chuwis-Thau wrote: "Long, idle hours are going on forever. It's as if the time stopped. [...] The roof is sizzling, the feelings of loneliness and danger are insufferable" ${ }^{310}$. In a prison, the time is perceived as a term of the punishment, the end of a defined period means regaining freedom, thus the thoughts of the prisoners concentrate on the end of a sentence. A prisoner specifically knows how long's the sentence going to last, he can count down the days till freedom by checking them in his calendar. Marking such stretches of time is a strategy helping one cope with its abundance. A hiding person is stripped of that privilege. A hiding place is like a dungeon, where the convict "rots" waiting for years for a death penalty, and nobody's going to inform him about the date of the execution. (This expression is present in one of the testimonies, verbatim: "We're alone. Back on the death row"411). Sometimes, hopeless against this ocean of time that is impossible to divide, conceive, tame, hiding people were setting "deadlines" them. It was irrational and not motivated

408 V. Bukovsky, I powraca wiatr... [And the Wind Returns...], pp. 14-15.

409 L. Silverstein, Tak właśnie było... [That's What Happened...], p. 167.

410 L. Chuwis-Thau, A jeśli... [And if...], p. 61.

411 J. Kostański, H. Grynberg, Szmuglerzy... [Smugglers], p. 122. 
by anything, but helped the people maintain equilibrium. Stefan Chaskielewicz, who was hiding in ruins after the surrender of the Warsaw Uprising, said: "When I was hiding in that spot I thought to myself that I can last 100 days tops. It was, of course, idiotic, but that thought kept coming back to me" ${ }^{\text {"12 }}$.

Mieczysław Ciosek wrote that one of the reasons why a long prison sentence is terrifying is that, compared to the dynamics of the life outside, nothing changes there for years: "the years spent in a prison usually mean the same or a similar place, the same clothes, the same events day-by-day, month-by-month, always similar memories and the same obsessive thoughts" ${ }^{413}$. Too few stimuli stem, among other things, from the specificity of prison architecture: its basic feature is to be functional, which means safety and locked space. Architecture in itself is not providing too many stimuli, as the aesthetics are far down on the list of its functional priorities. The cells and corridors are gray, with almost no furniture. Tall walls, bars, tiny windows with just a glimpse of the view of the sky one instantly associates with a prison... The inflow of the stimuli from the outside is also severely limited. Spending many days in the same room, looking out the window at the same view, having no other option, a person saturates this small fragment of the given space with a whole opulence of thoughts, feelings and meanings. Thus, a tension between the grayness of the undifferentiated reality and details filled with emotions and meanings is created. Marek M. Kamiński described "physical variables" of a typical Polish prison from the 1980s (this spatial model can serve as a sort of matrix, unchanged for decades): " $1-1.5 \mathrm{~m}^{2}$ surface per person. Typical cells have a surface are of around $8-14.5 \mathrm{~m}^{2}$ and it hold 6-9 prisoners. It forces people to control their movements more and to make a greater use of the vertical dimension of the space (bunk beds, double bunk beds). In some cells, the way of moving on the floor or between multi-story beds is strictly formalized. Reports of a possibility to 'walk' in a cell are almost everywhere. It was limited to a sequence of 3 steps - turn - 3 steps etc. In bigger cells, it was possible to do 5 or 7 steps: odd numbers prevent vertigo. The prisoners often 'walk' in twos or threes, getting a real knack for coordinating moves. [...] Grayness of the surroundings induces hallucinations in contact with the reality outside the pen. Shutdown of the stimuli received from the outside causes a state in which a tea essence ('czajura') has an effect of a drug. People make use of 'natural' power sources (light bulbs). A small number of available items leads to various ingenious ways of using them. Such items include: bread, plastic bags,

412 P. Chaskielewicz, Ukrywałem się... [I Was Hiding...], p. 90.

413 M. Ciosek, Psychologia sądowa... [Forensic Psychology...], p. 182. 
cardboard, chips from the floor, newspapers, dust bunnies, towels, pen refills, and rubber from the clogs' soles. They are used to make dice, cards, toys, primitive cutlery, oil lamps, tattoo guns, coil water heaters, and even electric pans"414.

A solitary and a hole are extreme examples of places where the lack of stimuli is especially pesky for the convicts. The complete impoverishment of such space resembles solitary hiding places in ruins, dugouts, places impossible to furnish or brighten up. We are nearing here at a boundary situation where in a long run a human being loses in confrontation with relentless, still and unchanging space: "Lack of books, newspapers, paper, pencil. They won't let you go out for a walk or to a bathhouse, feed you every other day, there're practically no windows, bulb is simmering in some niche under the ceiling, barely lighting it. The only ledge in the wall is your table, the second one is the chair. You can't last more than ten minutes on that chair. At nights, they issue a sheer wooden plank instead of the bed. You are not eligible for warm clothes. In the corner, there is a toilet or a simple hole in the ground, it stinks whole day long. Basically a cement sack. [...] It's here that you start going underwater, to the very bottom, right into the mud"415. In such a place, where it is impossible to settle in, "the sense of reality slowly whittles away, the body goes numb, moves become automatic. The further you go, the more you turn into a dead object" 416 .

When one is not crippled by hunger or the cold and can sit down relatively comfortably, needs of a slightly different level could have had their say. In gray, poor and ugly surroundings the longing for beauty emerges. The only way to satisfy it is escaping into dreams. Bukovsky recalls: "The whole time spent in the hole I was drawing on bits of newspapers or even the floor or the wall. Castles. I would not only draw their general outlines, but I made a point of building the whole castle, starting with the foundations, floors, walls, I would install the parquets and tile the floors with stone, furnish the chambers, hang pictures and tapestry, light the candles in the candlesticks along with the tarry, smoking torches in the endless corridors. [...] When I close my eyes I can still draw that castle with all of its details"417. One can miss the sky, the beauty of a landscape, the open space or happy past.

I have encountered a similarly intensive experience connected with space in memoirs of the hiding Menachem Katz. The author wrote about the long

414 M.M. Kamiński, Subkultura aresztów śledczych [Subculture of Holding Facilities], "Studia Socjologiczne" [Sociological Studies] 1993, Nos. 3-4.

415 V. Bukovsky, I powraca wiatr... [And the Wind Returns...], p. 17.

416 Ibid., p. 18.

417 Ibid., pp. 22-23. 
hours he spent in a bunker, when he was trying to occupy himself, focusing his thoughts on what was available. "I would fix my open eyes on the floor of the passageway. It was riddled with tiny rocks fitted into the beaten dirt. I gazed at each rock separately, from round ones to sharp pieces of granite, and searched for some intertwining patterns in this infinite mosaic. My eyes were looking for some picture or a figure in those patterns melting into one another. I used to smile faintly upon finding something: a sight of happy occurrences from the distant past, foggy and obscured, hidden behind a curtain of cruel experiences from the ghetto" 418 . The stone floor was the only thing he was able to lay his eyes upon, and the rhythm of the rocks stuck into the ground had a power to possess Menachem's thoughts. This property of the rhythm of architecture in its broad sense was noticed by Rasmussen, who wrote: "There is something mysterious in the stimulating influence of the rhythm. [...] A person listening to music feels the rhythm as something that exceeds the thought, something that exists in itself. [...] It often takes a human being over with no apparent effort on his side, allowing his mind to roam freely $[\ldots]^{\text {"419. }}$. A moment of such experience in a hiding place can be compared to a moment of a prisoner's concentration, who, in the familiar pattern of the flooring, springs of the bed or wires behind the window, finds a rolling rhythm that frees his thoughts. This is how the hiding Menachem Katz can fly on the wings of his thoughts far beyond the space of his cell.

In a prison, much like in a hiding place, due to a scarcity of space, every inch has to substitute the endless world outside for a convict or a hiding person. Because there is no replacement or alternative, one can only sit here and lay there, every detail and every change are important. Then, under laboratory conditions, when each object, as the sole representative of its kind, is preening and prancing on the stage, it clearly turns out how thin the line behind which the objects lose their functionality rally is... Bukovsky describes it very accurately on the example of bed and a "sitting appliance" in the detention. "Here is the bed, welded metal rods. There's a mattress on top [...] But it turns out that the prisoners sleeping on those beds have even announced a hunger strike demanding for the space between the metal rods to be reduced" ${ }^{220}$. It happened due to the fact that the prisoners were prohibited from collecting old newspapers, which they used to stick under the mattress, and "the bed has immediately turned into an instrument of torture" ${ }^{\text {" } 21}$. The example of the bed shows how efficiently the prison

418 M. Katz, Na ścieżkach... [On Paths...], p. 132.

419 P.E. Rasmussen, Odczuwanie... [Experiencing...], p. 134.

420 V. Bukovsky, I powraca wiatr... [And the Wind Returns...], p. 26.

421 Ibid., p. 27. 
details can ruin somebody's life and get inflated into an incredible size, provided one has no potential for controlling them. The case was similar for sitting, i.e. the major occupation of an inmate. Passive killing of time is not far from physical suffering: "One is entitled to a pole or some other sitting appliance in the hole, and each hole has that ledge in a wall, where you can keep on sitting all day long. But they made that ledge a bit higher and bit shorter than it should be - you can't sit comfortably, you can't put your feet on the floor. You'd think that it's just a few silly centimeters..." 422 .

In a hiding place the important parameters were subject to change not only because of an order from the top. There could have been infinitely more reasons, ranging from random events, forces of nature, laws of physics, to the wishes of the host or a person who owned the facility where the hiding place was located. M. Landsberg describes a result of such seemingly slight change: "The cold is starting to bother us, especially lately, since, due to the reduction of our electric current consumption we were forced to change a 40-watt light bulb for a 10watt. The forty used to heat up a lot and, together with our bodies, was somewhat warming up the scarce space of the shelter. The ten lights up cold, which, connected with minus fifteen degrees cold that came before the holidays, causes acute cold increased by the fact that we are constantly motionless. Our limbs are cold, we huddle together at nights to warm each other up" ${ }^{323}$. We can add here, paraphrasing Bukovsky - "You'd think that it's just 30 silly watts..."

Another tangent between a hiding place and a prison is a fixed rhythm of the day assumed in long-term hiding places, the discipline, rules even, strictly stipulating what is and is not allowed, appointing shifts and dividing responsibilities. In a prison, the personnel keep an eye on the compliance with the rules and regulations, but also serve the prisoners, e.g. providing them with food. In a hiding place, the compliance is guarded by the hiding people themselves. In case of an assisted hiding place, the helping person in some (of course limited) way becomes akin of a warden. By once interacting with the hiding people, the helping person links his or her fate with theirs, even if retaining a completely different position. By including oneself into the formulating system of functioning of a hiding place for example, by bringing the hiding people food every other day - the helping person regulates the rhythm of the passage of time for the hiding. If a hiding place is under that person's roof, that person decides the rules of procedure, designates the area of freedom and watches over observance thereof. It is done not so much

422 Ibid.

423 AYV, 033/1099, Journal of M. Landsberg. 
for the sake of preserving order, but to protect one's safety - exposing a hiding place means death for the helping person as well. This person has power over the hiding. That power can potentially be absolute: that person can throw them out or expose them, thus sentencing them to death. Usually, this person is of a different world due to living conditions (not hiding) and hierarchy of needs. In case of conflict of interests between the people hiding and the one that hides them, the former are at a disadvantage. An exception occurs when the hiding people are aided by a Jew with Aryan papers. In that case the situation of the "prisoner" and the "guard" becomes symmetrical. When in a hiding place, one has to accept those limitations, just like a prisoner has to accept the rigor. However, acceptance of the prison rules can be harder, since they are a made up, artificially created system and a feeling of soundness of a punishment has to appear in a convict's mind to make him or her willingly obey. Otherwise, a prisoner will rebel or will give up and obey due to being powerless. The rules introduced into hiding places had a clear goal: safety. They were also indirectly guaranteeing order in a forcefully created community. Those were reasonable basis to maintain the determined discipline. The things covered by the arrangement could include: food and water rations, keeping still and quiet, occupying specific places in a hideout, responsibilities of individuals, rhythm of the day. Yet a hastily established system had a shaky base. Both the tension accompanying everybody in a hiding place and the disparities between them (financial, gender-specific, familial etc.) caused conflicts to arise in connection with the order regulations. Those conflicts would often have dangerous consequences. Leon Guz, among others, described such a situation: "Rampant egoism would take control. Some reasoned that they deserved special treatment, for example because they were financing the whole endeavor [... ${ }^{\prime 424}$. In case when the rules are set by a helping person, a resistance from the hiding people could simply lead to them being thrown out of the hideout.

When deliberating over human attitudes toward the space of a prison, I wish to cite fragments of an ambiguous essay of Fatos Lubonji, an Albanian intellectual, who spent seventeen years in various detention centers as a political prisoner. In the 90s he's conducted a series of "visits to his prisons" (according to the essay's subheading). It turned out that the landscapes he used to look upon for years became close to him - "with an unexpected pain" he's accepted the changes in the space, which burnt into his memory so strongly. He wrote the following on the Spaç prison: "I left that place feeling a strange pain that I have lost the memory of what was that place's essence, not truly understanding why it pains me. It was

424 L. Guz, Targowa 64... [64 Targowa...], p. 149. 
especially painful to me that the places disappeared - the silent witnesses of my

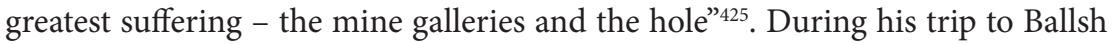
prison he would also look with disbelief at "remains of the former barracks those special and extraordinary barracks, once filled with human pain and unusual events, now resembling a cemetery of concrete poles and iron rods" ${ }^{\prime 226}$. The most important moment of that visit turned out to be locating an untouched piece of the space: a fragment of stairs between the barracks. A concrete construction, similar to thousands other staircases we walk past every day without a shred of interest in the towns all over Europe, but having a special meaning to the prisoners in Ballsh: "Those were the most important stairs in the camp, as from its top step you could see the road which the families would go down to visitation. Prisoners would wait on those stairs for hours on end, looking out for their loved ones carrying bags. And after the meeting they would pounce back up at full speed to see them once more and look at them go until they completely disappeared. I used to that all the time too, with a racing heart, for the three following years when I was waiting for my family" ${ }^{27}$. That glance outside the prison, exceeding its gate with the sight and thoughts was a touch of freedom. In general, visits of the relatives were a rare sign that the world outside truly exists. Visits of family members or people who knew about the situation to a hiding place played a similar role. A contact of the isolated people with the world was always an event breaking the monotony of waiting. Of course each such visit was experienced a lot heavier than in normal circumstances. An example of such an intense experience can be found in Leon Guz's works. The author of the testimony said that he's experienced a "strange feeling" connected with a "completely mundane experience", i.e. visit from an acquaintance. She was expected in the hideout with "much excitement", and after she left the people inside unanimously agreed that the visit was a "major experience..." A similar event in life of the residents of that hiding place was Easter of 1944 and baking pies connected with the holidays. The day of culinary preparations was, according to Guz, "marked by excitation" 428 .

The list of similarities between prison and a hiding place seems long. However, when it comes to the spatial aspect of a hideout, which is of the highest significance to me, it is not that simple. First of all, a prison is a standardized place,

425 F. Lubonja, Nostalgia i ból [Nostalgia and Pain], in: Nostalgia. Eseje o tęsknocie za komunizmem [Nostalgia. Essays on Longing for Communism], eds. F. Modrzejewski, M. Sznajderman, Wołowiec 2002, p. 9.

426 Ibid., p. 10.

427 Ibid.

428 L. Guz, Targowa 64... [64 Targowa...]. 
similar to other prisons, but also hospitals, offices and courts. It is an impersonal place, lacking individual characteristics, with gray cells and corridors perfectly embodying a totalitarian order. By contrast, hiding places are scraps of space stolen from the visible world, they can be literally anywhere, there is nothing official or institutionalized about them. A condition for a hiding place to exist is that irregularity and illegality of space. Every hiding place is different; it is often a place unlike any other. Even though it is hard to talk about giving a bunker, a dugout or a corner behind a wardrobe any individual features, we have to stress the uniqueness and separateness of each hiding place, its ephemeral nature, impermanence, which are completely unlike the stable block of the prison building. The hiding people could create their own space to an infinitely bigger extent than the prisoners, starting with the act of building a hideout from the ground up or choosing a place to be a hideout, through technical improvements and all pioneer solutions. I will write more on the subject in Chapter 4. In a way the hiding people acquire a status of an entity by this manner, they are active and creative individuals. The situation of prison objectifies people. Fate of prisoners is in a way similar to the situation of children, who are placed somewhere without having a say, whose only activity shall consist of adapting to the place where they happen to be.

Additionally, the space of a hiding place could have been a dynamic system, where the conditions of staying inside, including the level of the sense of being locked and isolated, could have depended on a number of factors which had a great significance from the perspective of a hiding place. Therefore the "bars" and "walls" of a hideout could have a varying level of permeability. As an example, I shall cite the experiences of Chaim Icel Goldstein and his companions whose freedom to leave their hiding place and wander around the nearby basements was limited by snow. "Through the night the snow covered the whole neighborhood and cut us off from the world. If we left, our footprints would give us away. I thought: a clean, bright and innocent snow that brings joy to the children who throw snowballs at each other and laugh wholeheartedly... That same snow can turn into prison bars for people buried in a dark bunker, become their enemy, traitor, warden, who is not letting them go out to search for food" 429 . At the same time the consequence of this sudden lock up of the previously half-open hiding place could have been a lot more dramatic than just an increased sense of isolation: "Because of the snow we could have starved to death" ${ }^{430}$.

429 C.I. Goldstein, Bunkier... [Bunker...], p. 157.

430 Ibid. 
In Ciosek's understanding the analysis of the space of a prison concentrates on the notion of social density. The author invokes the classical work of John B. Calhoun ${ }^{431}$, popularized by Edward T. Hall ${ }^{432}$, which posed a question about negative consequences of excessive density of people in a tight space. Overpopulation in a prison is prolonged and intensive, and the prisoners experiencing it are unable to change that situation. Additionally, the people in a prison constitute a particular social group with a higher average level of aggression. In such a society, excessive density can lead to life, health and property threatening situations for the weaker individuals. Density and overpopulation are featured especially in descriptions of collective hiding places, particularly in underground bunkers, which would often shelter incredible numbers of people. In this case overpopulation, with all of its negative consequences, occurred in its extreme variation. Obviously, that problem did not affect solitary hiding places (except for particular cases of hideouts "with a family", where one hiding person was in fact cooped up in a confined space with a group of people providing the shelter). The multitude of types and kinds of hiding places is resisting being reduced to a simple comparison with a prison cell. Among the collective hiding places there would also be such where the restriction of space had only a partial character. Hiding places of "Robinson Crusoes" can serve as an example here. They would virtually occupy whole deserted tenements, ruins, basements, thus having a large area at their almost unconstrained disposal. In case of woodland hiding places the stay in a cramped dugout would intersperse with an ability to use the unlimited space of a forest. Certainly, the common denominator of a prison and a hiding place is the proximity of random people on a limited space (regardless of its size). Except for cases when a whole family or a group of friends would hide together, the fate would often put strangers together in one hiding place. Those strangers, just like prisoners in a shared cell, had to work out their mutual relations so as not to turn the piece of space they had into a living hell. Stefan Chaskielewicz wrote the following about his companions from "craftsmen circles" who "spoke Polish improperly, with whom he happened to be located in a basement of a home at 131 Marszałkowska Street in Warsaw: "It was one way or another, but I had to somehow live with those people" 433 .

Finally, I would like to cite Lubonja and Bukovsky, who wonder years later about a peculiar phenomenon - missing the prison. Lubonja, surprised with his

\footnotetext{
431 J. Calhoun, Population Density...

432 E.T. Hall, The Hidden..., p. 23.

433 P. Chaskielewicz, Ukrywałem się... [I Was Hiding...], p. 82.
} 
need to visit his old prisons and the intensity of his sorrow after coming to contact with their space, diagnosed the situation in the following manner: "I began wondering what the nature of my nostalgia was. Initially I thought that it is a longing for the intense - in a certain way - experiences and emotions, for what was before and after, the joyous or painful, yet different. Everything that happened to me in prison was incredibly intensive" ${ }^{434}$. Bukovsky in turn contemplates the mood swings of a person who left a prison, concluding that the toll of that experience never allows to fully taste the freedom again: "Is there a nostalgia for a loony bin, longing for prison? Just yesterday, suffocating in the ambiance of madness, saturating everything, like the tar satiates a ship's deck, you dreamt: oh, Lord, if I could only get out of here! [...] But once you get through the prison door - everything goes to hell. The first person you meet, the dirty wooden fence on the other side of the street, covered with scraps of posters, scratched up tram, crowds of people rushing somewhere and the gray, lifeless estate apartment houses - that's all just a decoration and has absolutely nothing to do with you. [...] What do you want from me? Leave me alone, let me be. Don't touch me. I want to sit here, alone, look absently into space. I have to crawl into some hole, damp and dark one, have to shed the old skin. It pains me. Be quiet, don't shout, your yells are echoing inside of me - with a melodious echo like in an empty building, and no words bear the sound of thoughts" ${ }^{\prime 35}$.

\section{Summary}

In this chapter, I have focused on the category of meaning of a place. It is hard to separate it from the layer of overlapping meanings, passing time, oblivion, changes in space. In the beginning, one has to realize how common the phenomenon of a hiding place was during the occupation and where they used to be located, to look at a familiar landscape of a town, village and a forest and see a trace of a potential hiding place there, along with human presence. Sometimes, when possible, we can connect a place with somebody's name. Or, equipped with some number of testimonies, look for matching and similar elements in other texts. It looks like a work of a detective-archeologist. However, I cannot, and do not, plan to get to the actual soil, bricks and boards. Therefore, I do not uncover the layers of soil, but of memory written down in the texts. Once that task is complete, it will be possible to conduct an analysis of meanings consciously or not ascribed

434 F. Lubonja, Nostalgia... [Nostalgia...], p. 11.

435 V. Bukovsky, I powraca wiatr... [And the Wind Returns...], p. 218. 
to such places by people who hid in them, as well as the meanings they found in them, and which controlled their actions and reception of a hiding place.

It is not a universal approach, it is impossible to explain everything in this manner. However, I believe that by accurately decoding at least a part of meanings of a hiding place, it would be easier to... dare I say, "understand"? Maybe rather look for such a perspective that will allow us to see something important, something we did not think about before, by reading the texts - testimonies of that time. By talking about some issues using different wording, we uncover the hidden side of reality.

I have drawn this language directly from the authors of the testimonies, who themselves wrote about their hiding places: desert island, Noah's ark, animal burrow, fortress, grave, prison. Emphasizing various features of a hiding place, all of those phrases highlighted isolation of the hiding people from the society. Another equally wide metacategory covering some aspects of the space of a hiding place is a home. We associate passiveness, impotence, unfamiliarity, and helplessness against the oppressive space with prison. One's home is an active and positive attitude of a person toward the environment, warmth, liberty of proceedings and feelings. Chapter 4 will be dedicated to the issue of a hiding place fitting into a model of a home. I will also not leave out the concept of marginalization, which I am going to use to present homelessness of the hiding people, along with ways of changing that state. 



\section{Hiding place and a home}

The real world becomes obliterated whenever we transfer our thoughts to the home of our memories. What is the significance of the houses we pass by while walking down a street if our memory recalls our family home, the home of absolute intimacy, the home from which we derived the very conception of intimacy? This home is somewhere far away, we have lost it, and no longer live in it, and we know, unfortunately for certain, that we shall never again do so. Then the home becomes more than a mere memory - it is the home of our dreams.

Gaston Bachelard ${ }^{436}$

He already knows all the hiding places in the apartment, and returns to them as if to a house where everything is sure to be just as it was. His heart pounds; he holds his breath. Here he is enclosed in the material world. It becomes immensely distinct, speechlessly obtrusive. Only in such a way does a man who is being hanged become aware of the reality of rope and wood. Standing behind the doorway curtain, the child himself becomes something floating and white, a ghost. The dining table under which he is crouching turns him into the wooden idol in a temple whose four pillars are the carved legs. And behind a door, he himself is the door - wears it as his heavy mask, and like a shaman will bewitch all those who unsuspectingly enter. At all cost, he must avoid being found.

Walter Benjamin ${ }^{437}$

I see a family home that is no longer there.

Leon Najberg ${ }^{438}$

Using the concept of home, which is key in this chapter, I shall now attempt to closely analyze one of the aspects of a hiding place that I have mentioned in Chapter 2 - a hiding place as a social space: hideout as a construct of the people who are hiding, who create it in a literal, physical manner, actively building it from the ground up or substantially changing a pre-existing construction. This way my deliberations shall tap into the field of architecture, or rather its humanistic analysis. By using the idea of homelessness (supported by the idea of marginalization) I will attempt to describe wartime fate of the Jews from an angle of losing one's home. By diagnosing the situation of homelessness as a crisis, I will

436 G. Bachelard, La poétique de l'espace, Paris 1957 (anonymous translation http://www. domowat-mosfera.art.pl/opow0.htm);

437 Benjamin W., Berlińskie dzieciństwo około roku tysiąc dziewięćsetnego [Childhood in Berlin around 1900], "Literatura na Świecie" 2001, No. 8/9, p. 112-113.

438 L. Najberg, Ostatni powstańcy getta [Last Ghetto Insurgents], Warsaw 1993, p. 47. 
present the process of building a hiding place as a part of universal human experience - creating and making do in a situation of crisis.

\section{Home}

\section{The concept of home}

To live means to dwell. We are unable to go without an apartment. A sedentary human has a deeply rooted need to have a home. But even the nomads, after completing another stage of their wandering, organize space for at least temporary dwelling.

Janusz Andrzej Włodarczyk $k^{439}$

It would seem that a home is as old as the humanity. However, according to various mythologies, including the Bible, people did not use to need a home at all. Bohdan Paczowski stated: "In the mythical beginning, in Eden and in the Golden Age, people would never work, which included building. The nature was a home for them. One can imagine that caves were the first shelter for Adam, along with the firmament or canopy of trees. Only after losing the natural state of grace, in exile, when, as Genesis states, his wife bore his children in pain, he learned the toil of labor and had to create an artificial shelter for himself. To make it out of branches and animal hides he had to harm the nature by injuring trees and killing animals" ${ }^{\prime 40}$. Therefore, a home is a response to the first distress and crisis: ever since men stopped feeling safe in the house of their God, learned fear and saw enemies around them, they started to desire a shelter they would not have to share with anybody. A place, where they would be safe and feel at home.

According to that rationale an act of creating a home was on the one hand a step toward emancipation, self-empowerment and taking on life's challenges on one own. On the other hand, it was a violation of the hospitable nature, a piece of which was separated from the whole while using up its resources and harming it. Finally, it was a gesture of disrupting continuity with the surrounding world. By putting up walls of his home a man showed that he's no longer one with the trees, animals and meadows of Eden. He's set boundaries and for the very first time felt that the security obtained in this manner means isolation and severing primal bonds as well. We can look for the birth of culture here, where human

439 Włodarczyk J.A., Żyć znaczy mieszkać. Dom mieszkalny na granicy stuleci [To Live is to Dwell. Residential Building on Turn of the Centuries], Tychy 2004, p. 14.

440 K. Janowska, P. Mucharski, Rozmowy na nowy wiek [Conversations for the New Century], vol. 3, Cracow 1999, p. 172. 
beings change the natural landscape into an anthropogenic one $e^{441}$. By transforming the closest surrounding space humans mark it with their existence, knowledge, thoughts and desires.

This anthropological dilation indirectly takes me to the real origins of home, the genesis of this idea in history of humankind. I am not planning to recreate evolution of the idea of home in detail, as comprehensive studies on the subject already exist ${ }^{442}$. I would just like to briefly name the basic contents which are at heart of the idea of home and which make us call some place a home. Then it will be easier for me to isolate new meanings in the description of the key category of the space of a hiding place.

Basic qualities connected with the idea of home can be grouped in two areas: stability and security. In the first area we will be faced, among other things, with an idea of rootedness, which was described by Simone Weil as follows: "To be rooted is perhaps the most important and least recognized need of the human soul. It is one of the hardest to define. A human being has roots by virtue of his real, active and natural participation in the life of a community which preserves in living shape certain particular treasures of the past and certain particular expectations of the future. This participation is a natural one, in the sense that it is automatically brought about by place, conditions of birth, profession and social surroundings. Every human being needs multiple roots. It is necessary for him to draw well-nigh the whole of his moral, intellectual and spiritual life by way of the environment of which he forms a part" ${ }^{\prime \prime 4}$. This word has multiple synonyms, which reiterate the motif of bond, possession, belonging, relation. A verb to habit, formerly used to mean "dwell", comes from Latin hebere - "to have". Thus "'To dwell' does not simply mean to 'be inside'. It additionally means 'to possess something, i.e. bestow that place with our presence. Not only with our activities and possessions, but also our dreams and desires" ${ }^{\prime 44}$. Other words often used in anthropological descriptions of residing somewhere include $d w e l l i n g$ and nesting. The last one is especially noteworthy, as meaning "to create a nest" 445 .

James J Gibson, the creator of the theory of perception, who was mentioned in Chapter 3, uses a different word when talking about a home. A home is "a

441 See J. Kaczmarek, Podejście geobiograficzne... [Geobiographical Approach...]

442 See W. Rybczyński, Dom. Krótka historia idei [Home. Short Story of an Idea], GdańskWarsaw 1996.

443 S. Weil, Zakorzenienie [Rootedness], in: S. Weil, Wybór pism [Selected Works], vol. 1, Warsaw 1983, p. 247.

444 W. Rybczyński, Najpiękniejszy dom... [The Most Beautiful House...], p. 174.

445 J.J. Gibson, The Ecological Approach to Visual Perception, Boston 1979. 
shelter" that protects a human being from variable features of the atmosphere. By uncovering characteristics of various surfaces, people began to use them as shelter, initially relying on pre-existing caves and other formations of the terrain, and building homes later in their evolution. Houses consist of a certain number of unchanging elements, such as walls, roof, floors. People use those elements to protect key functions of their organisms. "A home is a shield, shelter to which human kind can retreat, like into a cave secured against rain, wind and light. They can huddle with a sense of complete security and relaxation, like an animal in its burrow" ${ }^{" 446}$. When we invoke that complex of associations: locking oneself up, hiding, darkness, crannies - we will find common characteristics of a home and a hiding place. While a hiding place cannot guarantee rootedness and sustainability, it still attempts to be that cave, to protect from cold, rain and bad people. The model of an animal burrow, which I have presented in Chapter 3, echoes here. We are now tapping into another important characteristic of a home - it is supposed to provide safe existence in a hostile world. Those two scopes of meanings are closely connected. On the one hand, when we are in a place where we feel safe, we can "put down roots" in there. On the other hand, a place we chose to be ours alone, one we possess, is in our power - therefore nobody is allowed to disturb our peace in there.

Main qualities aside, I shall mention another sociological aspect of a home's functioning - namely it being a crucial piece of the social puzzle, a place where a family resides. A home adapts to conditions of its era, hence changing throughout the ages, yet always remaining a part of the complex network of social relations. A place where people feel at home, where they invite other people, where they establish a certain order and mirrors in miniature the social order in force outside of it; finally, a place where people gather their strength before their everyday confrontation with reality. "An apartment should unite two kinds of needs: needs of the family as a whole and of each member of that family individually. Therefore, we are dealing with two areas of space inside: the socio-familial and private-intimate ones" ${ }^{\prime 47}$. But it was not always the case - homes of the rich used to be big, but more people lived inside of them, a larger family, servants, guests. The poor, in turn, would have a swarm of people simply cooped up in a small, non-diversified space. For a modern man from the circle of our civilization a home is associated with intimacy. We can assume that it was an abstract notion

446 S. Giedion, Przestrzeń, czas, architektura [Space, Time and Architecture], Warsaw 1968, p. 449.

447 J.A. Włodarczyk, Żyć znaczy... [To Live Is...], p. 90. 
for our ancestors. In an old-time home, everybody would live together with no walls, curtains or privacy. Private bedrooms appear in European homes only around the $18^{\text {th }}$ century. In the $20^{\text {th }}$ century, a suite of rooms was still popular. A chain of home-dwellers would go through them back and forth. Until as late as the middle of $20^{\text {th }}$ century "all members of a family used to live everywhere and nowhere" 448 .

Consequently, when analyzing the idea of home, we have to avoid anachronism, i.e. looking from the contemporary perspective. A home and an apartment are universal human experiences which are, however, not identical for everybody. Researching history we can see that in various cultures, times and social strata the homes and domestic habits were highly diversified. When it comes to the matter of a home, its size and comfort, there is no comparison between a palace of an industrialist from Łódź or even a home of a middle class man and a home-workshop of an impoverished craftsman from a shtetl. There is a stark contrast between a domestic habitus of a person living in luxury or moderate comfort, on a considerable space, in a bright, warm and clean apartment, and a habitus of a pauper who's used from his very birth to dirt, tightness of space, darkness, repulsive smells, lack of not only an individual room, but even an individual bed. Poor people would often live in something that a modern man would recognize as a dump; it was so in cities, towns and especially in the villages. The civilization distance separating a hiding place from a home of such a person is not far. The distance from a rich house and a hiding place is tremendous. An issue with representativeness of the sources arises here - written evidence was more often left behind by people with a slightly better life situation (literate, with a habit and need of writing). We do not know what a hiding place meant for the poor people from a shtetl. We can only imagine that for them this experience was probably extremely difficult to a lesser extent solely because of the material conditions, but rather because of the psychological strain (fear, lack of sense of security, no sense of ownership).

In Chapter 1, I have already mentioned cases of poverty, or even utter deprivation of countryside dwelling places. I shall also cite a description of an apartment of a poor resident of Warsaw. The man has entered his journal into a contest organized by the Institute of Social Household in 1933. "Everything I eat is usually put on the table, I mean a sort of rough counter with perpetually wobbly legs mended with hopelessly thick boards painted with lime. The table is often covered with old foreign newspapers and I gawp at them idiotically. There are two

448 Ibid., p. 91. 
chairs at the table. They have ill-fitted hardboard seats and nails stick out of them and catch my trousers when I get up. We also have a black whatnot with four shelves and a knob that keeps falling on the floor. The only apparatus we have on in is an alarm clock, which is also from the way before. In the corner, between the window and the whatnot, there is a single bed. Mother sleeps there, so I don't really know what goes on in there, but I can say a few words about my bed. It's a camp bed [...]. It's important to note that in the gaps between the wooden frames and leather upholstery there are swarms of bedbugs [...]. When I sleep I cover myself with two things: my overcoat and mother's topcoat. It's a bit uncomfortable, because whenever mother goes somewhere and takes the coat, I just lie there and my teeth chatter from cold, as I sleep by the window, which is not very well fitted nor has double glazing. [...] The walls of our apartment are painted with a tone with a hint of blue paint. [...] In one corner of the apartment the walls are very leaky, as they are adjacent to the stables, which is constantly damp. Our floor is interesting too; it is an elaborate patchwork of various rotten boards [...]. And our measures to drive out the centipedes and cockroaches from the wet crevices are for nothing. The vermin stuck to us so tightly, that there is no way of sending them to hell" ${ }^{449}$. This apartment definitely has a higher standard than village huts with clay dirt-floors, but the cold, dampness, scarcity of appliances and infestation make it very similar to a description of a typical hiding place.

Silesian "poor homes" from reportage by Wacław Piorun (1936) are even more similar. They are overcrowded, dark and as primitive as the woodland dugouts from the time of occupation: "Poor homes, half way buried in the ground and half way built from sheet metal, tar paper and old wood, have one wall adjacent to an old powder magazine. The unemployed built them a few years back. There are seventeen families living inside of them. They are so big that there are more than a hundred people together in those mud huts. The chambers are tiny, usually completely dark or with one window. Each family made it so they don't sleep in beds, but wherever they find a space on the floor" ${ }^{\prime 40}$.

\section{Architecture and construction - how is a house created?}

I shall now briefly present an outline of the concept of "architecture" (in constant conflict with "construction"). Its essence is an active and creative opposition to hostile conditions and circumstances. As Włodarczyk wrote, "a residential building can be specified as a basic spatial substance of the world around us and the

449 C. Miłosz, Wyprawa... [Journey...], pp. 378-379.

450 Ibid., p. 382. 
essence of architecture. On the verge of one's adult activities a human being always starts with acts connected with creating, but not necessarily building one's own home" 451 .

Before I touch on the issue of active participation of a human being in creating the space around, I shall say a few words about the eternal discussion about what is and isn't architecture. "There are two notions: architecture and construction. A question about the difference between the two is basically the question about the essence of architecture" ${ }^{\prime 452}$. The dispute on that difference remains open, as proved for example by the multitude of definitions of architecture. Some authors refer to the beginnings of our civilization, citing the treatise by Vitruvius entitled The Ten Books on Architecture. Vitruvius lists fundamental features of a good building - durability, utility and beauty. Probably that last category, forcing one to take the aesthetic value into account, compels us to make a distinction between architecture - an art form, from construction - a craft ${ }^{453}$.

A discussion about ideas shall not become a centerpiece of this chapter. When it comes to particular hiding places and its constructors, the emotional load and the symbolic value of those human creations makes me inclined to agree with Rybczyński, who wrote: "Architecture is sometimes called an art of construction, yet this is an evaluation of the effect and not the cause. When we recognize some objects, which strike us as 'architecture', it does not matter if they are huge or small, famous or not, if they are sheds or cathedrals. And it does not matter who designed them" ${ }^{354}$.

An analysis of the idea of a home makes me think about the primal instinct of a human looking for shelter and about slowly adding subsequent cultural advances to the initial instinctive actions. First there was a cave, which was

451 J.A. Włodarczyk, Żyć znaczy... [To Live Is...], p. 7.

452 A. Basista, Opowieści budynków [Stories of Buildings], Warsaw 1995, p. 16.

453 Deliberations on the subject can be found in Janusz Włodarczyk’s book Oblicza architektury [Faces of Architecture]. There is in fact a chapter entitled Boundaries of Architecture. While following the history of definition of architecture, he notes an evolution of understanding this idea from a strict division of "architecture" and "ordinary construction". Till this day many experts exclude facilities simply called "constructions" from the scope of architecture. According to Włodarczyk, they are wrong to do so: "And yet the image of space that surrounds us, especially in an urban landscape, is made up with a whole plethora of elements we normally do not associate with architecture" (J.A. Włodarczyk, Oblicza architektury [Faces of Architecture], Białystok 2000, p. 20). Those elements include both industrial constructions: factories, silos, and small elements of space: phone booths, poles, bus stops, fountains...

454 W. Rybczyński, Najpiękniejszy dom... [The Most Beautiful House...], p. 18. 
internally organized by humans insofar as possible. "We still don't know if the so-called notion of a cave formed in humans as a result of mimicking other animals, or as a result of an internal impulse, and what came first - the notion or the mimicry" ${ }^{\prime 55}$. Another step toward a home and architecture was made when the humans stopped being satisfied with preexisting shelters created by nature. Then it occurred to them to connect elements to create a whole that would mean more than a simple sum of those elements. Augustyn Bańka commented on that dual nature of the beginnings of architecture: "Architecture can both come from the primal instinct of security, synonymous with an 'archetype of a cave' and from the reason, which is nothing but an image of the world in which the time fuses with space, emotions with cognition, and freedom with determination, i.e. predetermined fate. In the first case architecture would be everything that has a utilitarian character from the point of view of survival, as a value in itself and one that was biologically programmed. In the second case architecture is everything that is a reflection of a psychological order" ${ }^{\$ 56}$.

Searching for the beginnings of architecture, one would like to pinpoint the sources of structural ideas of the first constructors. Andrzej Basista, when talking about Sumerian structures from Ur, traditional forms of domes of the roofs unchanged for centuries in Aleppo and about Italian trulli, says that it is now impossible to trace where the various elements of constructions we now see in distant places of the world come from. "The thing is that the basic construction systems such as pillars and beams [...] were probably 'invented' many times throughout history, independently in various parts of the world. It is easy to see that people figure some elementary inventions out on their own by trial and error; they do not have to be instructed by anybody, and they do not have to copy other people's achievements" ${ }^{\prime 57}$. The author compares this process to a child playing with blocks finding out some solutions. While playing, the child gradually discovers basic laws of physics, deals with gravity until it works out an optimal formula securing stability and a desired shape of the construction. Thanks to that quite obvious comparison architecture presents itself as a universal and fundamental experience of human beings.

In later epochs, the architecture evolved, bringing forth various styles and countless increasingly complicated objects. From my perspective categories of

455 A. Bańka, Architektura psychologicznej przestrzeni życia. Behawioralne podstawy projektowania [Architecture of Psychological Life Space. Basic Behavioral Design], Poznań 1997, p. 5.

456 Ibid., p. 6.

457 A. Basista, Opowieści budynków... [Stories of Buildings...], p. 40. 
design and construction bear a larger significance than styles and aesthetic decisions, as they are seeking to solve a problem: how should we tame the space to find a place for our actions and satisfying our needs there.

There are various theories outlining those processes, majority of which are a heritage of environmental psychology, previously mentioned in Chapter 2 . This field is tightly connected with architecture. Good design, which is substantial for architecture, can't do without researching the basic parameters of environment which influence people. In the 60s a term "architectural psychology" was coined and became a hit in Great Britain. One of achievements of those two fields coming together was recognizing the user of architecture as a party equally important in the design process. At the same time, many theories of design were worked out in United States, all of them attempting to capture subtle patterns of that process - natural for people and now almost completely taken over by professionals (including Studer's behavioral theory of design, Rittel's "wicked theory", and Bezjanc's theory of design as learning. I find "pattern" theory of Alexander to be the most interesting. It seeks interdependencies between problems a designer faces and designing a particular form. Designing should start from an analysis, i.e. dissecting a problem and organizing its components. Only then one can embark on synthesizing a form. Alexander's created a whole system of diagrams allowing people to resolve design problems. Another element of Alexander's theory was creating "patterns of behavior", which he presented in his famous book entitled A Pattern Language (1977). Alexander claimed that human behavior can be captured in a "language of patterns" - recurring elements and solutions that have to occur in every building adapted to those behaviors. It allows the designers to make use of the experiences of their predecessors. Alexander's created a whole catalogue of those patterns, suggesting solutions for all the problems. An important point of Alexander's theory was giving all the users of architecture a rank of designers, following an assumption that every human has his own patterns worked out through interacting with space. A professional architect only assists, in accordance with his knowledge, in verifying correctness of the user's ideas and helping him find the best solutions. Rybczyński phrased the above a bit differently. He wrote: "We build our own home relying only on the local construction language and what John Habraken called a 'collective image' of a home. It is clearly defined by culture. [...] Architects often fail to see that image. [...] However, it is our hidden consciousness, an image or a notion that we all carry inside. Expression and reproduction of such image was once a daily occurrence. It was such a mundane event that it was missed by historians, which explains their lack of interest in sheds. Now building one's own home is 
considered a luxury available only to the few, even though, paradoxically, this is how a majority of impoverished people in the world has to endeavor to get their own home"458.

Who knows if the most important process of building a home is not started when the architects (or constructors) rest, when the walls, floors and roof are already in place? For the created space has to be organized and animated by human presence - a home is nothing without its inhabitants. A concept of "housing" is discussed e.g. by Louis Wirth ${ }^{459}$, who talks about it social aspect, aspect of relations with local community and their political and economic aspects. I find the concept of domestication of a home by residing in a particular space significant. Peter King ${ }^{460}$, inter alia, wrote about it when attempting to capture an intimate relation between residents and a space, a relation on the plane of physicality of space and of a human being, which determines the essence of a home.

Therefore, one has to assume that a home begins when it is domesticated. The relation mentioned by King derives from habits and customs. We know the house we live in "by heart", we move and act routinely, without thinking, because we fuse with space in which we live for a prolonged time. A home becomes a part of us and we a part of that home. A habitual movement in a space we know and which we have created and tamed ourselves combines the two features I have written about in the beginning of this chapter: rootedness and a sense of security. When everything is in its place, nothing surprises us, we feel at home in a home. A successful process of domestication is in fact a fusion of a body and its surroundings, "embodiment" of a home ${ }^{461}$. It is accompanied by props - archetypes present in every home, associated with warmth and convenience: lamp, table, bed, furnace, armchair mentioned by Tuan ${ }^{462}$. Even an impoverished home has a number of objects making life easier: pots, bedding, furniture, white goods. Those items are necessary, but ordinary, similar to those of our neighbors, disposable. A home is also a place for unique objects, reminding the residents about their identity: family memorabilia, personal possessions, documents, photos; in short, unique objects with sentimental or official value.

458 W. Rybczyński, Najpiękniejszy dom... [The Most Beautiful House...], p. 192.

459 L. Wirth, Housing as a Field of Sociological Research, "American Sociological Review" 1947, No. 12(2).

460 P. King, Private Dwelling. Contemplating the Use of Housing, London-New York 2004.

461 J.C. Kaufmann, Ego. Socjologia jednostki [Ego. Sociology of an Individual], Warsaw 2004.

462 Y.F. Tuan, Space..., pp. 136-143. 
All those things create a home. A home, in turn, creates the people who live inside. They come together as a whole, they are a mix of features, feelings; ordinary and unique items. The whole - a home and its residents - despite appearances, are a fragile construction, one that is being created slowly and for a long time and which is easily destroyed. So let us now move on from deliberations on creating a home to an analysis of its wartime destruction and social consequences of that process.

\section{Homelessness - lack of home as a threat to safety and life}

And they still have gloomy eyes, hiding something deep down. Maybe it's the unsatisfied desire of a home. Something comes to their minds and immediately gets lost... - Let me go home... I didn't do anything wrong to anybody. Let me go home - Tońka would beg [...]. Everything's going home, not looking around, not asking anybody about nothing - we are going home. Not anywhere. You go to your street, your yard, your hallway, through your chamber doors. "We're home" - mother used to say.

Leopold Buczkowski ${ }^{463}$

Homes were always first to fall victim of historical catastrophes, wars and revolutions. It was no different during the Second World War in Poland. Solutions connected with homes and creating them as a part of human civilization have to be now applied to wartime situation. I would like to briefly discuss what a Jewish home became during the war and what could have architecture became to people looking for shelter. I have to introduce two useful concepts here: homelessness and marginalization. Those notions are tightly intertwined. As Hanna Palska wrote: "A homeless person is marginalized in a way 'to the fullest'. One can lose a job, money, loved ones, but usually still has his own address and place on earth. Homeless people are stripped of that last 'material of identity"'464.

\section{Homelessness and marginalization}

Theories connected with the issue of homelessness are mostly a heritage of the contemporary. They describe contemporary homeless people and that group differs to some extent from a traditional model of a homeless person: a victim of war, catastrophe, or simply somebody who does not fit within the incumbent

463 L. Buczkowski, Czarny potok [Black Creek], Warsaw 1965, p 253.

464 H. Palska, "Mnie się pogmatwało w tym pijanym moim życiu, pozagubiało..." [It all got confused and misplaced in that drunken life of mine...], a "shortened" biography of a homeless alcoholic (case of Z. family, No. 25), in: Zrozumieć biednego [To Understand the Poor], ed. E. Tarkowska, Warsaw 2000, p. 258. 
social and economic orders. In the old-time Poland (and Europe) the homeless people would consist of the so-called loose people - vagabonds, servants and other wage workers, travelling merchants, people thrown out of a home, village idiots, "church panhandlers" etc. ${ }^{465}$. First, I shall attempt to present the most general definitions and categories which organize various aspects of homelessness.

"Everybody knows who a homeless person is" - these words could serve as a motto for my deliberations. Paweł Poławski ${ }^{466}$, citing those words of his respondent asked about the issue of homelessness, illustrates a paradox, which is actually typical for many social phenomena. Even though everybody has come in touch with homelessness and believes it to be a real issue, it is hard to describe homelessness using scientific language. "In many publications (if not in majority of them) we see deliberations connected with definition vagueness of the concept of homelessness and a homeless person. Authors of those deliberations often attempt to create a universal definition, useful in practice of helping the homeless", said Monika Abucewicz-Szcześniak ${ }^{467}$. There is a whole group of definitions, ranging from narrow to broad ones:

- sensu stricto definitions: homelessness reduced to having no roof over one's had, no apartment,

- sensu largo definitions: the definition includes an element of evaluating the place of residence as below standards (e.g. can we call slums an apartment).

We can also present this division in a different variation:

- literal homelessness,

- potential homelessness.

465 See B. Baranowski, Ludzie gościnca $w$ XVII-XVIII w. [Highroad People in $17^{\text {th }}-18^{\text {th }}$ centuries], Łódź 1986; M. Frančič, Ludzie luźni w osiemnastowiecznym Krakowie [Loose People in $18^{\text {th }}$ century Cracow], Wrocław 1967; B. Geremek, Ludzie marginesu w późnośredniowiecznym Paryżu. XIV-XV wiek [Marginalized People in Late Medieval Paris. $14^{\text {th }}-15^{\text {th }}$ Centuries], Poznań 2003.

466 P. Poławski, Obrazy bezdomnych i bezdomności. Instytucjonalizacja reakcji na problem społeczny [Images of the Homeless and Homelessness. Institutionalization of Reaction to Social Issue], in: Polityka społeczna. Wybrane problemy. Wybór artykułów $z$ lat 1999-2005 [Social Policy. Selected Issues. Selected Articles from 1999-2005], Warsaw 2005.

467 M. Abucewicz-Szcześniak, Bezdomność we współczesnej literaturze przedmiotu [Homelessness in Contemporary Subject Literature], in: Polityka społeczna. Wybrane problemy... [Social Policy. Selected Issues...]. 
Or:

- overt homelessness,

- hidden homelessness.

Narrow definitions are easy to apply, but they are not exhaustive, while the broad definitions are often not accurate. Between the narrow and broad understanding of homelessness there is a continuity of cases. Some authors ${ }^{468}$ find the criterion of a possibility to change the situation of a person perceived as homeless to be important. Therefore, they define homelessness as a state of evident and relatively permanent depravation of residential needs, a situation that cannot be prevented or changed by the affected person alone.

Some authors call for dividing homeless people according to their psychophysical state (capable of independence versus incapable) or according to the duration of homelessness (chronically, briefly, "frictionally" homeless). The issue continues: are there people who are homeless by choice? Andrzej Przymeński postulates to use the phrase "homeless at one's own fault" instead. The discussion concerns, among other things, two categories of people: criminals, people conflicted with the judicial system who, running away from their responsibilities, abandon their permanent place of residence, and permanently dysfunctional people, who are unable to adapt to living in a permanent place of residence. Homeless people can be additionally categorized according to various life situations ${ }^{469}$ :

1) people from the street, living on train stations, in tunnels, pipes, at attics, in dumpsters; those people are homeless in a narrow sense, "the poorest of the poor";

2) residents of shelters and night shelters;

3) immigrants, refugees, including those accommodated in camps or centers;

4) prisoners evicted into nowhere;

5) squatters in vacant buildings, houses prepared for demolition;

6) residents of mental hospitals, social assistance facilities, who could live on their own, but have nowhere to go.

468 A. Przymeński, Bezdomność - społeczno-ekonomiczne uwarunkowania zjawiska na przykładzie Poznania [Homelessness - Socio-economic Determinants of the Phenomenon in the Case of Poznań], "Praca Socjalna" [Social Work] 1997, No. 3; Zjawisko bezdomności w Polsce współczesnej [The Phenomenon of Homelessness in Contemporary Poland], "Polityka Społeczna" [Social Policy] 1998, No. 4.

469 T. Kamiński, Wokół pojęcia bezdomności [On the Phenomenon of Homelessness], "Roczniki Naukowe Caritas Rok I" [Caritas Scientific Yearly, Year I] 1997. 
Tadeusz Kowalak, when writing about the phenomenon of homelessness in the European cultural circle ${ }^{470}$ drew attention to an inevitable marginalization of homeless people. "A non-homeless person is a part of various important organizations such as a family, local community, country, school, team of workers [...]. He's connected with the social structure through relations with close and distant relatives, friends, neighbors, compatriots [...]. Those connections cause rights and responsibilities to arise, powers and obligations, they constitute a person's social status, determine that person's social behaviors. A homeless person, in turn, lacks those connections, is not responsible for anything, doesn't govern anything, and has no influence on anything. Activity of such person is limited to maintaining his biological existence" ${ }^{\text {"711 }}$. According to a synthetic definition of exclusion presented by Ryszard Szarfenberg ${ }^{472}$, excluded people are affected by deficiency of participation in social life, access to goods, institutions and social systems, fulfillment of their vital needs (poverty) and social rights.

The notions of marginalization and homelessness have many tangents. Szarfenberg uses the phenomenon of homelessness as a metaphor explaining the place of "redundant people" in a society. He tells us to imagine a society as a few-story home with diversified rooms along with people who exist outside of that home: permanently excluded or excluded "intermittently".

Stefan Czarnowski, when defining the issue of social exclusion in a now classical article entitled Redundant People in the Service of Violence ${ }^{473}$ noted that in "unstable times" the amount of excluded people grows rapidly. Czarnowski wrote those words in 1930s, not being yet aware of the devastation that will befall European societies during the Second World War. The phenomenon of exclusion of the Jews as a prelude for their extermination was in turn defined many years after the war by Raul Hilberg ${ }^{474}$. In his model, the first step is defining and marking, next there is expropriation, pushing the people stripped of resources and rights outside of the scope of society. Following steps - deportation, concentration and physical liquidation - are consequences of the primary exclusion of the group sentenced to annihilation.

470 T. Kowalak, Marginalizacja i marginalność społeczna [Social Marginalization and Marginality], Warsaw 1998.

471 Ibid., pp. 132-133.

472 www.ips.uw.edu.pl/rszarf/wykluczenie.

473 S. Czarnowski, Ludzie zbędni w służbie przemocy [Redundant People in the Service of Violence], in: S. Czarnowski, Dzieła [Works], vol. 2, Warsaw 1956.

474 See R. Hilberg, The Destruction... 


\section{War as a cause of homelessness}

I told you before - I left home in July 1942 and never came back... and I will never be at home anywhere! Sometimes I dream about home. I think we're all homeless. [...] Where we are now, where we live - these are all just flats. You see - flats! [...] And that - I mean from before the war. That home, that life were real. That was true.

Adina Blady-Szwajger in conversation with Anka Grupińska ${ }^{475}$

By applying concepts of homelessness and marginalization to the description of the phenomenon of a wartime hiding place, I would like to quote three authors. Here is what Piotr Łukasiewicz ${ }^{476}$, Katarzyna Kasjanowicz ${ }^{477}$ and Madeline G. Levine ${ }^{478}$ wrote on the issue of losing a home due to war.

Łukasiewicz, in his essay entitled Funkcje domu w okresie okupacji niemieckiej [Functions of Home during German Occupation], puts the situation of the hiding Jews into a wider social context. "It's not much of a discovery when we say that the civilian history of each war is a story of 'people on roads', as Kerstenowa puts it. Situation of occupation's coercion that individuals faced was especially severely pursued by taking away the people's freedom of choosing a place where they lived - including staying in their current place of residence". Author listed three sources of threats for the integrity of a home during occupation: military actions (combat, bombings, and "scorched-earth" tactics); German plan of "systemizing nations" with a premise to move some groups to certain places and annihilation of others and a "state of completely depriving the conquered people of freely disposing both of themselves and their property"479. Threat to a home and its destruction were achieved to the fullest in case of Jewish homes. However, Łukasiewicz put a comparatively small emphasis on this subject, placing the homeless Jews next to other people, who were hiding for various reasons: "The extraordinary situation of occupation created categories of people that were unknown in the times of peace, having an unusual social 'allocation' and place in social structure. Status of some of them, for example the hiding people, was directly or indirectly determined by their 'residential situation'. Fate of the hiding was chosen by people who were in danger of being exterminated or repressed.

475 Grupińska A., Ciagle po kole [Still Round], Warsaw 2000, p. 169.

476 P. Łukasiewicz, Funkcje domu... [Functions of Home...].

477 K. Kasjanowicz, Dom w getcie warszawskim [Home in Warsaw Ghetto], master's thesis, Warsaw 2006.

478 M.G. Levine, Bezdomność w literaturze wojennej: typologia obrazowania [Homelessness in Wartime Literature: Typology of Imaging], "Teksty Drugie" [Second Texts] 1999, No. 4.

479 P. Łukasiewicz, Funkcje domu... [Functions of Home...]. 
For them, in turn, abandoning their own home, place of their permanent residence was a chance for salvation. The hiding Jews, whose facial features were a giveaway, were in danger in every public place - they were condemned to stay at home, the meaning of which was in that case limited to four walls hiding them from the eyes of unauthorized people. For some people, a 'home' meant a bunker, basement, cupboard or a wardrobe. It would often happen that hiding meant acquiring an ability to live in a completely new way" ${ }^{\prime 30}$.

From my point of view the work of Katarzyna Kasjanowicz is more interesting. She has thoroughly developed the threads raised by Łukasiewicz in his essay, concentrating on gradual annihilation of a Jewish home during the Second World War. The author formulates theories based solely on memoirs and texts of testimonies of residents of the Warsaw Ghetto. In Chapter 1, she defines a home as a space of everyday life, a system of reference setting the framework for human activity and at the same time protecting people against the outside world and its threats. A home is a symbol of consistency, stability, a world where people build a life. War disrupts that order in human experience. It breaches a specified area of everyday life, changes its rules and imposes new ones. It is a total phenomenon, and as such it influences the whole of social life, and, because of its power, rapidity and momentum, it is an unstoppable force. After the turgid time of fighting the invader, the occupation sanctions the imposed order, where the rules and habits from the "regular times" are no longer in force. Kasjanowricz wrote about the war as a time of rooting up: dispersion of communities, destruction of tangible property, disruption of preexisting social order.

A home does not come out of this altercation unchanged either. "For people living in the times when the existing structure of order is not disrupted, the integrality of a home is its evident feature. [...] We use terms such as: 'my yard,' 'my tenement', 'my corridor', 'my door', 'my four walls', which indicate symbolically giving property to space which is not ours from the point of view of the law. In each of those private terms there is a confidence that those places are safe. [...] War is a type of experience during which one has to be able to imagine anything. Destruction of what seemed to be indestructible - the residential constructions made in order to serve generations, loss of the most valuable items (from material and emotional points of view), and demise of the loved ones - young and healthy people, who could have lived until they died of old age in times of social normality" 481 .

480 Ibid.

481 K. Kasjanowicz, Dom w getcie... [Home in...], p. 23. 
For many people, the September bombings were the first ever war experience. They suddenly made people realize how fragile are their homes and how hopeless they are in the face of the force of bombs. They became aware of the fact that war can affect and destroy every home. There are no longer any safe homes. The author discussed the subsequent stages of annihilation of a Jewish home: German plundering, forceful displacement to ghettos, where many people got a taste of homelessness for the first time, and finally physical annihilation of the homes during displacement actions and during the Warsaw Ghetto Uprising. An interesting thought is extending the idea of Jewish home to the whole of Poland - the mythical land of Polin. The war has also irretrievably destroyed that home, where Polish Jews used to live for hundreds of years.

Kasjanowicz has dedicated an especially significant amount of space to a home in a ghetto, which lost its basic features of a safe shelter: new flats are tiny, uncomfortable, poor, often shared with random flat mates. Even rudimentary intimacy is hard to obtain. "In the closed off district the doors of apartments, just like the walls, do not isolate individuals from the outside world, they give no protection, individuals have no power over them. They don't knock on the door, they pound; they are not opened, but broken down. You can say that the door of an apartment in the reality of a ghetto become an element of the dangerous outside world - the sounds come from behind it and inform people of the imminent threat, always give in to the blows of the oppressors and let them force their way inside" ${ }^{382}$.

During displacement actions and planned destruction of Jewish districts a home became nothing but a death trap. Even this miserable, temporary ghetto apartment, abandoned by its residents rallied up to a train car, is a tragic site. The author cites descriptions of homes with a trace of human presence left, giving "a warm breath of a life that has not been extinguished yet" 483 . The mentioned texts describe the Warsaw Ghetto's reality, but such sights were easy to spot in almost every town from which the Jews were cast away. A generalized literary portrait of such a home was painted by Leopold Buczkowski: "They went up the stairs covered with lime. In there, in a giant room, in the very middle, there was an armchair with a worn-out seat. Walls dark from smoke, riddled with nail and bullet holes. Over the entrance to the next room there was a black velveteen tapestry with a lion embroidered with golden thread. There were cups on the mantelpiece and half-burned stockings under the furnace, along with cotton balls, boxes of

482 Ibid., p. 47.

483 K. Żywulska, Pusta woda [Empty Water], Warsaw 1963, p. 61. 
needles, buttons, a kids' chair. [...] they have seen the same things everywhere. Broken mirrors, papers, chairs, plaster, ripped pillows, heaps of black ash and corpses collapsing in their rags. Here and there the dead people were sitting on windowsills. The draft was blowing pieces of paper here and there with a humid air from the fields. Butterflies were flying around the empty rooms, flashing their wings and landing on bronze candlesticks when tired" 484 .

This is how Kasjanowicz summarizes the perspective of physical annihilation of a Jewish home that she drew herself: "What have those mutilated, partially demolished homes with burned up interiors and no people whod take care of them become? Designed by an architect in respect to the number of people in a family, they lost their functions and no longer served anybody. With no roofs nor windows, no human voices, about to completely collapse, were endangering the people who hid inside of them or the few passers-by. They were no longer arousing any positive associations, only terror and sorrow of those who used to live there before the war. Only the memories of the people who still remembered the prewar time were connecting those tons of rubble, bricks and stones with an idea of a residential building" ${ }^{\prime 25}$. The author continues to deliberate a broader perspective of losing one's home - disintegration of the Jewish community, dystrophy of family, and finally individuals giving up on saving themselves and their loved ones. This process is called an annihilation of a "spiritual home".

A short text by Madeline G. Levine is worth citing due to an interesting concept of "domicide" presented therein. In the very beginning of her work the author confirms that the motif of a home and losing it is an arch of the majority of wartime literary works. In her text she analyzed purely literary works, yet the categories she uses can be useful in reception of other texts. She aptly notes that during the war "homes, from being shelters, become places of deadly danger; distorted forms of home life, often limited to fighting for survival, are sustained in places that one would never consider livable before: basements, pens, bunkers and secret hiding places. And even they cease to exist when their once strong walls turn into ash and rubble" 486 . Lavine drew the concepts key for her text from works of J. Douglas Porteous, a geographer who made a distinction between domicide (destruction of a residential building) and topicide (destruction of a whole area, community) in his article entitled Domicide: The Destruction of

484 L. Buczkowski, Czarny potok [Black Creek], Warsaw 1965, p. 96.

485 K. Kasjanowicz, Dom w getcie... [Home in...], p. 50.

486 M.G. Levine, Bezdomność... [Homelessness...]. 
$H_{0 m} e^{487}$. According to Levine's interpretation, a domicide, aside from a physical destruction of a home, means a "literal and symbolic breach or ripping out its intimate interior; a home is turned inside out"; a topicide, in turn, makes "a family home turn into a hostile territory". That last experience is defined by the author as a common fate of the Jews. She cites works of Władysław Szlengel (Telefon [Telephone]) and Ida Fink (Odplywający ogród [The Ebbing Garden]). "The painful abandonment" is harder to bear in case of the Jews, because - as Levine wrote - on example of residents of the capital, which was destroyed after the Uprising: "all the surviving residents of Warsaw have undoubtedly experienced a loss of their place of residence and their city, but a thing that the Poles never experienced is a loss of the conviction that their country, even if divided and under occupation, is still their country".

Each of the mentioned texts has a few accurate observations and valuable analyses. I will now attempt to present my own analysis of the issue. Firstly, we have to wonder to what extent the category of homelessness used in modern sociology will be helpful in description of the situation of the Jews hiding during the Shoah. The modernity of that category seems to be the biggest obstacle here. The definitions cited above describe the situation of homeless people from the turn of the $20^{\text {th }}$ and $21^{\text {st }}$ centuries, in times of peace and in a democratic country. Context of the war and occupation changes the way of functioning of the basic social phenomena, therefore we can compare the situation of the hiding Jews to e.g. the fate of refugees from war-stricken countries. Homelessness of the time of war is a peculiar phenomenon.

In a situation of constant life threat, which was surely experienced by the hiding Jews, the problem of losing one's home can be treated as secondary. It is, however, worth taking a closer look at those people from the perspective of their homelessness as well. First let me say a few words about the conditioning of that homelessness. The structural circumstances seem to be the most important: the break out of the war and gradual introduction of anti-Semitic legislations. It would seem that all personal conditioning, connected with family, psychological situation, lifestyle etc. are secondary. During the war all Jews, with no exceptions, were first sentenced to be pushed out of the public space, robbed of their possessions and rights, and then to death. Of course, the varieties of destinies of individual people, and especially their chances to survive, were diversified depending on their wealth, religiousness, contacts with

487 J.D. Porteous, Domicide: The Destruction of Home, in: The Home: Words, Interpretations, Meanings and Environments, ed. D.N. Benjamin, London 1996. 
non-Jewish friends, knowledge of Polish (Ukrainian) language. Yet every person that experienced homelessness when hiding was sentenced to that fate by a structural aspect of history.

Even the very moment of moving into a ghetto, the commotion and mess connected with the borders of the future Jewish district not being precisely set meant the first housing crisis in many towns. Creating a ghetto in Kolomyia is a case in point. It was described in the journal of Marceli Neider, a rich and well-connected man, who still experienced much trouble and distress during that time. I wish to quote a substantial passage from his text. "There's a rush in the apartment offices of Qahal. People pay steep compensations, big money for so-called orders, i.e. allocations to Qahal apartments. Some owners of homes with gardens try to make a switch with Aryans living in probable Jew[ish] districts. [...] You can't arbitrarily rent out flats without Qahal's permission [...]. Meanwhile, a spontaneous move starts. Whoever has a flat is wheeling their junk, who doesn't have one is spreading their things among friends who live somewhere near synagogues, as those streets are the most certain ones. [...] Sunday, March $24^{\text {th }} 1942$ is here. It's only been a week since I moved to the upper at (84) Dzieduszyckich Street after moving from Moniuszki Street. They gave me this flat as a very sure one, meaning that it was supposed to become a part of the Jewish district. I was assured about that in apartment offices of Qahal. So on that Sunday my landlady comes to me all worried, asking if I know anything about the fate of that street, as everybody is packing and running. [...] Indeed, there's commotion in the street [...]. Ones from the upper side run down, ones from down pull up. [...] But where to? When nobody knows anything for sure yet? They say that the Qahal officials already know and they are the ones that caused all this havoc. We run to Qahal we're just in time - they are reading out the streets incorporated into the district. Plenty of streets that were 'sure as eggs' are out, but they've added a few that people were not expecting. [...] I get a new allocation, I get a wagon somewhere for a ton of money and pack my stuff myself. I've been in the new apartment for a week, maybe 10 days - and the expenses? And losses? And damaged things? Stolen provisions and so on? I get to the place with much trouble [...]. I unload the stuff and suddenly it turns out that this neighborhood (Słowackiego Street from the bridge and to Łamana Street) has just been excluded as well. What to do? I go back to Qahal and there is a sea of people in despair. It's forbidden to stay at somebody else's place, where are they going to sleep? I get a new 'oder' for a flat thanks to my connections. I gallop to the place of new allocation. Meanwhile Pola was waiting there with unloaded things in the middle of the yard. [...] My new allocation is the corner of Dzieduszyckich and 59 Słowackiego Street. Oh, 
misery - about three more candidates are allocated to the same flat - two of them are already there with wagons of stuff" 488 .

Neider, an officer of Jewish Ghetto Police, finally finds a "nice flat", but a lot of his neighbors went through things like that: "Complaints, fights, apartment takeover - that's what you heard the whole day. Eviction after eviction. Putting another two, three families into an occupied room. There was commotion, screaming. One went to a friend to file a complaint, other cried that he doesn't want to spend the night in the street. [...] Not all people from Kolomyia have apartments, hundreds of them are crushing at friends', other camp out on the squares, in gardens, some are staying at synagogues and other shelters. Whoever had protection at the apartment offices of Qahal, whoever paid, who knew the Qahal's chieftains, got a better apartment quicker, the poor were at the mercy of mass accommodation in synagogues or, seeing the hopelessness of waiting for a better lodging, went up to attics and to sheds" ${ }^{389}$.

To present the situation of people who found themselves in a ghetto already as homeless, let us now go over the example of Warsaw. Many thousands of Jews who lost roof over their heads, including the people displaced from the territories incorporated into The Reich, refugees from Cracow, prisoners of war liberated from German camps went to Warsaw before the ghetto got closed off. In this group, there were also people who lost their homes in bombings and fires. Warsaw municipality was already facing a problem of finding those people a place to stay. "Refugees coming to Warsaw in the first wave of displacements, weary from the rigors of long voyage, tormented by searches and beaten by Germans, mentally exhausted, were still carrying some leftover possessions with them. Some of the people at risk of being deported would try to leave on their own to be spared the brutality of compulsory displacements. Packs of refugees walking the streets of Warsaw were giving them a unique brand. The refugees were conspicuous, they were different, lost in an unknown world, hopeless"490. The already sealed off the Warsaw Ghetto is accepting new groups of displaced people, the people forcefully deported from their places of residence. In the beginning of 1941, they amount to a few tens of thousands of people, more people come in 1942. Those are mostly residents of small towns near Warsaw.

Those people were the lowest social layer of ghetto's society, especially susceptible to infectious diseases (especially typhus), suffering from hunger. The

488 AYV, 03/2076, Memoirs and journal of C. [sic!] Neider.

489 Ibid.

490 B. Engelking, J. Leociak, Getto warszawskie... [The Warsaw Ghetto...], p. 308. 
refugees had the highest mortality rates in the ghetto. They would live in shelters, so-called points, only few were lucky enough to live with friends or relatives ${ }^{491}$. Synagogues, prayer homes, industrial buildings, cinemas etc., i.e. places completely unsuitable for residential purposes would become such "points". Additionally, large groups of people were placed in small spaces. The number of refugees in such "points" ranged from six to seventeen thousands of residents. There were initially around 160 points. Their number later declined. The conditions inside were bad: there was no heating, no plumbing, and no useful appliances. "Those were the worst places in the whole closed off district: hubs of extreme poverty, diseases, mass hunger and death" ${ }^{492}$. Inhabitants of such "points" who survived till July 1942 were the first ones to be sent to Treblinka.

When it comes to the Jews who had a roof over their heads in the ghettos in the initial phase of the Shoah, often even living in their own prewar homes, one can wonder if the difficult and deteriorating living conditions, overpopulation and poverty were qualifying their situations as a hidden homelessness (potential). According to today's standards - probably yes. Now, I would like to focus on the situation of the people who have decided to hide to save their lives either already in the ghettos (during displacement or liquidation actions) or on the Aryan side.

In some situations, choosing a hiding place did not automatically mean losing a home. That was the case of temporary hiding places, which used to save lives in ghettos during actions. Based on numerous testimonies we can distinguish several kinds of such hiding places: a hideout prepared in somebody's own apartment (a cupboard, wardrobe, room behind hidden door), a hideout in somebody's home or tenement, but outside of a flat (attic, basement, outbuildings), special bunker, most often built under a tenement by a community of neighbors who came together for that very purpose. All those types of hiding places used to be located in a close proximity of an apartment. By using those hideouts people did not assume that they were indefinitely abandoning an apartment, but merely temporarily making use of a place that was deemed safer for some reasons and that they were to return home when the immediate danger is gone. However, there were cases in which that return was impossible. This occurred for example when the Warsaw Ghetto Uprising started. Initially some civilians believed it to simply be another displacement action. The following days of combat lead to

491 A. Żbikowski, Żydowscy przesiedleńcy $z$ dystryktu warszawskiego $w$ getcie warszawskim 1939-1943 [Displaced Jews from the Warsaw District in the Warsaw Ghetto 1939-1943], in: Prowincja noc... [Night Province...].

492 B. Engelking, J. Leociak, Getto warszawskie... [The Warsaw Ghetto], p. 311. 
such substantial destruction of homes that it was impossible to return there. Finally, it turned out that this action is, in fact, the end of the ghetto and the homes abandoned by people hiding in the bunkers were simply no longer there, just like the whole district. Residents of other ghettos on the territory of occupied Poland who hid before an action were in a similar situation. When the Germans retreated and left the desolate and often ruined ghetto, there was physically nowhere to return.

People who left the ghettos and went to the "Aryan side" were in a similar situation. They would unexpectedly find themselves in a strange world and, in a way, deprive themselves of a roof over their heads by their own actions. These attempts were most often undertaken by people who had some friends or relatives on the Aryan side, or any type of base from which they could start anew. Let us note that some people, when obtaining so-called "Aryan papers", were making an attempt to completely blend into non-Jewish community, thus making them subject to other, specific mechanisms and conditions. However, here I am only focusing on the people who were hiding their physical existence, i.e. they were in various types of hiding places. People, who escaped ghettos having a "connection" on the Aryan side, could at least count on getting a temporary shelter, often at somebody's home. However, there were a considerable number of people looking for their place on the Aryan side as if groping in the dark, without anybody's help, not able to lean on their friends or any organization. Many of those people found a hiding place on their own or with help of random people. Their wandering in search of a hiding place through villages and forests is one of the most tragic cases of homelessness. At the core of the problems there most frequently was their social loneliness (or, in other words, marginalization) and bad financial situation. Małgorzata Melchior, describing how the authors of accounts from Warsaw District she analyzed managed to get a shelter in exchange for money, added: "People with no material resources, lacking any means, were in a completely different situation, which was often dramatic. Homelessness and hunger were the basic issues of the everyday existence of ghettos escapees. [...] People would also painfully experience the cold and lack of personal hygiene. [...] All those everyday problems stemmed from scarcity of resources of Jewish escapees, but also from indifference, animosity and even hostility of the people they have encountered along the way" ${ }^{\prime 93}$. Thus, an extreme depravation, struggle for the most basic items, food and clothes, was the essence of the everyday life of a significant portion of the residents of hiding places.

493 M. Melchior, Uciekinierzy z gett... [Escapees...], pp. 342-345. 
When it comes to the psychophysical aspects of homelessness of the hiding Jews, their living conditions were, of course, highly diversified, depending on a multitude of factors. Some people were lucky enough to live in comparatively good conditions, did not experience poverty or hunger. But some of the people hiding for an extended period of time experienced all the physical and healthrelated issues mentioned above and connected with extremely difficult living conditions. We can in turn assume that mental issues: emotional pressure, fear, constant sense of danger, loneliness and isolation, were experienced by every hiding person. Even those who were feeling comparatively well physically were not excluded, as everybody was aware of the danger, temporality of the shelter, uncertainty of the situation, hostility of the outside world. To those issues we can add the tension arising inside groups of hiding people caused by conflicting interest, different status of the members, need to stay locked up for a long time with often random companions. We should not forget the virtually inevitable conflicts with people providing shelter, especially if they were strangers sheltering the Jews for money. Financial issues lead to irritation and even tragedy.

In the end, I would like to note another, deeper aspect of homelessness. The people hiding would often feel alone, being aware that their whole family, neighbors and friends were murdered. That loneliness was often connected with guilt I have survived and they are gone. The whole Jewish world was dying before their eyes. Authors of the testimonies often felt like they were the last surviving Jews in the world. The lost home broadens its meaning, homelessness does not only mean no roof over one's head, but also no loved ones and no place to stay in this mutilated world. (This is fully in line with the above-mentioned conclusions of Katarzyna Kasjanowicz on losing a "spiritual home"). Words of Perec Goldsztajn from Hoshcha from the Volhynian Voivodship sound truly poignant. Goldsztajn was hiding on a farm in a village close to his home. One day the citizens of Hoshcha were rounded up and chased for six kilometers from the town to "Simons' birches", where a mass execution took place. His wife and children were probably killed there. "I told the farmer, who was keeping me, that I'm going back home. I can't stand to be here anymore. I'll go mad. Walking all day long in the darkness. I lie down, get up, sit down, an immense fear is trampling my soul. [...] The farmer hitched up the horses and we left for Hoshcha. I called it 'going home. What home? I couldn't myself imagine what the word 'home' meant to me. My home is at 'Simons' birches' with my family, I have no other home..." ${ }^{494}$.

494 Życie i zagłada Żydów polskich 1939-1945... [Life and the Shoah 1939-1945...], p. 563. 
The homelessness reaches its definitive stage. It is irreversible - just like losing a family, home and the whole world in which one grew up and lived before the war. That face of homelessness and attempts to counter it would probably make up for a whole separate book on the subject of postwar situation of the survivors and their attempts to build their lives anew on the ruins.

\section{Things and homes in hands of the neighbors}

Many people had money in Dobre. Jews left everything behind. Tenements, shops, merchandise - the ones they had in shops and the ones they have hidden away - furniture, appliances, even clothes. [...] People in Dobre were no monsters and some truly sympathized with the Jews. But, essentially, they were glad. Even the ones that felt sorry. There was so much new free space in the town. So many various goods. [...] And who came back to claim their things? How many dresses did mother recognize from the ones that people would bring to be refitted?... Who came back to Dobre? Us, Nusens, Fryds - nobody.

Henryk Grynberg ${ }^{495}$

There is an important thread not mentioned in texts of Kasjanowicz, Levine or Łukasiewicz. For the whole duration of the Shoah a process of stripping the Jews of all the items that would connect them with material world continued. Just as if the people sentenced to death no longer had a right to own anything. Thus, others would steal their things, which used to be located in their former, true homes, and for which there was no longer room when the home vanished. Objects that were suddenly, from one day forward no longer allowed to be owned due to an arbitrary prohibition. Objects that could have created a home in a hiding place, reminded one of the former life, and even objects necessary to survive. I include this phenomenon to considerations about the essence of wartime homelessness, as the connection between owning a home and owning things that are used to furnish that home and are utilized by people in their everyday life is clear to me. Losing them, connected with losing a roof over one's head, is another step of being cast into ultimate homelessness.

In 2011, a noteworthy book by Irena Grudzińska-Gross and Janusz Gross entitled Złote żniwa [Golden Harverst] was published. The book explores an issue of the economic aspect of the Holocaust and enters it into public discourse. Before the subject was popularized by a discussion on the yet to be published book of the Grosses, this thread was sometimes mentioned in works of researchers of the Shoah. For example, it was written about at length by Jacek Leociak, who's inserted a passage entitled Ci, którzy rabuja [The ones who rob] into his

495 H. Grynberg, Zwycięstwo [Victory], Wołowiec 2001, p. 134-136. 
text Wizerunek Polaków w zapisach Żydów $z$ dystryktu warszawskiego [Image of Poles in Notes of Jews from Warsaw District]. From the text, which was written based on a representative collection of Jewish testimonies, it appears that the experience of losing one's possessions was a common experience. It goes without saying that the occupants played the leading role in those occurrences, as they made the objects robbed from the Jews an important element of their wartime economy. Subsequent German regulations were stripping the Jews of the right to possess various articles and money, houses in the ghettos were burglarized, and the Germans seized almost all possessions of the people murdered during actions and in extermination camps. An anonymous account from Białystok says that the German seizure was not necessarily exercised in the scope of the law set by the occupants: "The walls of the ghetto were not stopping the harassment from unwanted visitors who would constantly come inside. The Germans were visiting the nicer apartments, browsing our things as if they were shopping for the nicest stuff. They were now the rulers of our possessions. They searched for jewelry, undergarments, clothes, soap and other things they needed. They would tell us to bag it and without saying a word to anybody - why and for what - leave our homes. They were illegal robbers, taking everything for themselves, fearing higher officials and the authorities" ${ }^{396}$. However, here I wish to focus primarily on the robberies perpetrated not by the hands of the executioners, but of the witnesses - neighbors. "All the others [aside from the Germans] who wanted and dared to jump at the 'chance' given them by the Germans (segregation and separation of the Jews; taking their rights away, especially the right to live; harassment, persecution, killing) were able to participate in the robbing. [...] We are talking about possessions of the Jews placed in the ghettos or staying on the 'Aryan side', which they wanted to keep somewhere safe to secure a financial support for them in fight for survival. The possessions hidden in this manner are under protective custody of Polish neighbors, friends and acquaintances. We are talking about money and valuables that people jumping out of death transports, abandoning an exposed hiding place or running from a manhunt could have had on them. We are also talking about clothes and undergarments they have on themselves. We are also talking about the already 'post-Jewish' possessions, i.e. everything left behind by the Jews who were taken away and murdered. The Germans have the right of way in robbing [...], hence the careless robbers get severely punished. Germans set the rules and organize this practice themselves. For example, they publicly sell stolen objects in the streets for next to nothing or

496 AJHI, 301/6641, Anonymous testimony. 
simply let the people take some of those possessions [...]. Those German rules are regularly broken and the robbers conduct 'exploratory' activities on their own, sometimes risking their lives" ${ }^{\text {"997. }}$.

Leociak asks us to note that stealing Jewish objects or apartments could have taken various forms: robbing "by force or deception" "fforce" often simply meant murdering the robbed victim) or taking the objects when the owner was no longer there.

When it comes to the first phenomenon, villages and forests were a frequent, if not the most popular scenery of robberies on the hiding Jews. Groups of peasants would close in on a dugout they have tracked to strip it bare. Aleksandra Bańkowska wrote: "The most striking is the fact that the victims would lose practically everything they had, including their clothes. The quality of those clothes could not have possibly been high, considering the conditions of hiding in the dugouts. Winter clothes and boots were most in demand. In the accounts authors rarely admit having money or other valuable objects" ${ }^{\text {"498. }}$. Such a robbery required the perpetrators to use force, take advantage of their numbers and physical power and was, aside from the financial loses (which resulted in practically eliminating a chance of survival), a traumatic experience, an encounter with a pure form of violence.

Bańkowska and Leociak talk about robberies perpetrated using deception as well - the simplest form of that was a refusal to give back the objects given one for safekeeping. There are no markings of direct violence here, but a dramatic breach of a relationship, that must have once connected the Jew and the Pole who offered to help keep an eye on the possessions. By exploiting the situation of the thieves, who must have believed they were clever, were abusing the trust of the robbed people. Perhaps such a theft perpetrated by somebody they knew and whom they have entrusted with their valuables was even more painful than being robbed by strangers. A deception is not very distant from force. As Bańkowska wrote: "Going to pick up one's belongings could have also ended in tragedy: it sometimes happened that the threatened peasants would turn in the people who came to the police or assault them themselves" ${ }^{\prime 99}$. Szmalcownictwo, i.e. blackmail, was a separate issue mention in the literature ${ }^{500}$. It meant forcing the Jews to give away their possessions under a threat of turning them in. Szmalcownicy

497 J. Leociak, Wizerunek Polaków w zapisach Żydów... [Image of Poles in Notes of Jews...], pp. $426-427$.

498 A. Bańkowska, Las jako miejsce... [Forest as a Place...], p. 70.

499 Ibid., p. 72.

500 J. Grabowski, Ja tego Żyda... [I Know...]. 
[or, alternatively spelled, shmaltsovniks - translator's note] would most often simply demand money, but sometimes it also happened that they would take whatever caught their eye. A text describing a loss of a sweater - a flimsy ersatz of domestic warmth - is especially painful in the context of Jewish wartime homelessness. It happened to Jochwed Kantorowicz: "And one hag saw us there. Seeing that we have a loaf of bread on us she said: 'You have a stolen loaf, give it to me'. We have started begging her to leave us alone. We have started appealing to her conscience, saying that the bread means life to us and we'd rather she took our lives than the bread. She saw that my sister had a jumper [...] and said: 'Give me the sweater then'. We have started persuading her again: 'But you have a home, you can warm up there, we have nothing. But the hideous hag could not have been reasoned with. She was deaf to our pleas. She took the sweater off my sister and started trying on my shoes and gloves" 501 .

Not letting Jewish possessions to stay without an owner for just a second was a common phenomenon, especially in small towns. Polish residents witnessed the displacement actions and against the will of the Germans or with their silent consent could immediately cover the distance between them and the deserted Jewish homes to take the objects that were, in a way, not belonging to anybody anymore. Descriptions of the lootings can be found in some texts by the Poles who witnessed displacements of Jews and the scenes that played out directly after. Zygmunt Klukowski, Polish physician, was shocked to see how the residents of Szczebrzeszyn were acting. They would hunt Jews, actively help the police drag out the hiding people and kill them. Those crimes were accompanied by widespread robberies, almost unnoticeable with all the violence. In October of 1942, Klukowski wrote down: "Jewish apartments are partially sealed. Despite that fact there are full-on robberies" ${ }^{\text {022 }}$. Similar observations were made by Feliks Tych $^{503}$, Franciszek Ryszka and Józef Chustecki. The first note down his observations from the displacements of Jews from Krynki. He wrote about the astounded peasants, whose emotions apparently did not kill their practical sense: "Yet the carts soon started going to Krynki to get quilts, furniture and kitchenware from there. Virtually anything of any value". Chustecki wrote something similar after a liquidation action in Prudno: "The Jews accompanied by tears and children weeping are getting loaded: old people and women with children on carts, everybody able to walk - on their feet go to the church. People's brains are already

501 AJHI, 301/2493, Testimony of Jochwed Kantorowicz.

502 Z. Klukowski, Dziennik $z$ lat okupacji [Journal from the Occupation], Lublin 1958, p. 290.

503 F. Tych, Dlugi cień... [Long Shadow...], p. 35. 
calculating how much they can get from each Jew. They greedily track what the Jews are taking with them and what is left to be robbed. The town is empty without the Jews, the last carts have left and the sharks went after their prey". A teacher from Kozienice, Kazimierz Mróz, when describing a "sale in the ghetto" in his wartime journal in October of 1942, was disillusioned about people adhering to the rules of acquiring Jewish possessions set forth by the occupants. In his description, he emphasized how puny the hauls were: "Some would buy and others would steal whatever they could. People would talk about fancy ladies dragging awfully dirty rags. Other would carry an old damaged three-legged stool. Another one has hidden a broken suitcase behind Mr. Guzowski's fence. Somebody was carrying an old basin. A lot of sooty pots, dirty chamber pots - often with the contents, the accessories, as they'd say. People would often ask if others knew what those dishes are for. People are stealing metal junk from kitchens, glass from the windows, even from Polish homes forcefully given to Jews. One man came up to me with candlesticks and asked if they were silver. Yesterday, a glazier came to me with some putty in parchment with some Jewish scribbles. Children are carrying Jewish hats, various pieces of paper, stamps, wires, clips etc." ${ }^{504}$. The author sarcastically noted moral permissiveness of his co-residents: "Mr. M. was outraged, because he heard the mayor say that the town can be fined 8000 zlotys for stealing property from the Jewish district". People were sometimes punished for looting in Kozienice, the Germans would confiscate the strangest things that Poles had: "20 windows and 16 doors, another one had 20 kilograms of soap, other 100 shoe uppers, and one had $1 / 2$ kilogram of tea from before the war".

The quotes above present the theft of Jewish possessions as seen through the eyes of Poles. The Jews in hiding were often aware of the situation - for example Neider ${ }^{505}$ noted in his journals the names of the neighbors that he was certain "had Jewish things". Leon Najberg, who was hiding in the ruins of the Warsaw Ghetto, wrote about the looting he witnessed: "On the $8^{\text {th }}$ of June [1943] we noticed Poles looking around in Jewish homes. They were there without German escort. [...] The Poles we have noticed were collecting all kinds of discarded things that were lying around the yards and were meticulously searching the basements and former shelters taking everything that had any value for the living people 'on the other side'. They went back with heavy sacks - by a passage only they knew - to the 'Aryan' district" ${ }^{506}$.

504 K. Mróz, Kozienice 1939-1944 (fragmenty dziennika) [Kozienice 1939-1944 (Passages from a Journal)], "Wieś Radomska" [Radom Region Village] 1993, No. 4.

505 AYV, 03/2076, Memoirs and journal of C. Neider.

506 L. Najberg, Ostatni powstańcy... [Last Ghetto Insurgents], p. 109. 
Aside from losing all possessions, the final nail to the coffin of wartime homelessness of the Jews was the inevitable seizure of a Jewish home by their Polish neighbors. That process started at the very beginning of the war, when the Jews were rounded up in the ghettos and thrown out of their homes. It continued during actions and displacements, a status quo was reached and sanctioned after the war, when the Poles started moving into 'post-Jewish' homes that were still intact. (Word "post-Jewish" [pożydowski] itself is worth analyzing. It earned a permanent place in Polish language). The Jews were presented with fait accompli and would often be eye witnesses to the place they left being taken over when the abandoned rooms were still warm. Calel Perechodnik described Jews from Otwock waiting to be driven way, looking at the "new homes being built on the ruins, reaping the fruit of their work" ${ }^{207}$. That process, which was not only limited to seizing homes, but applied to workshops, shops etc. as well. Kazimierz Wyka was analyzing this phenomenon just after the war, bitterly remarking: "Now from under the sword of German executioner committing a crime unprecedented in the whole of history, a Polish shopkeeper was pulling keys to the register of his Jewish competitor and believed it to be a very moral thing to do. The Germans get the blame and the crime, we get the keys and the money. [...] A golden tooth pulled from a dead man will never stop bleeding, even if there's nobody to remember where it came from"s08.

That new order of things settled in no time and when the war ended the voids were completely filled ${ }^{509}$. Fate of the few survivors who managed to get to their hometowns after the war and who wished to return to their homes (or to get them back, sell them and restart their lives somewhere else), was not an easy one. Jerzy Tomaszewski, in his lexicon entitled Jews in Poland wrote: "Jew's coming out and returning to a hometown was sometimes in danger as well. People who took over the possessions left behind by the Jew[ish] families were afraid that the returning Jews would demand their property back, especially an apartment or a home. Murders would often happen on those grounds" 510 . I have come across an accurate illustration of those postwar years in Grynberg's novel Zwycięstwo [Victory]: "Mother did not even attempt to sell our share of the tenement. Things like that irritated people a lot and were sometimes dangerous. Some Jew came to Minsk to sell a home and it cost him his life. People got used to the fact that

507 C. Perechodnik, Spowiedź [Confession], Warsaw 2004, p. 98.

508 K. Wyka, Życie na niby [Make-Believe Life], Cracow-Wrocław 1984, p. 157.

509 See A. Skibińska, Powroty ocalatych [Return of the Survivors], in: Prowincja noc... [Province of...].

510 Żydzi w Polsce. Dzieje i kultura. Leksykon [Jews in Poland. History and Culture. Lexicon], eds. J. Tomaszewski, A. Żbikowski, Warsaw 2001, p. 168. 
the former owners are dead and they are the new owners of the homes they live in"511. When the woman had no choice, and decided to arrange a trade, it turned out that her worries were justified. "They didn't show their faces to anybody in Dobre, just went straight to the tavern where they were to meet somebody who wanted to buy that part of the tenement. Since the man was not coming for a long time, they ordered a diner. Suddenly a dirty, unshaved peasant entered the tavern. He ordered vodka, drank it, spread in his chair and, looking at mother, started smiling in that ugly way that people like him do when looking at Jews. Tell her! - He addressed everybody but mother. - Tell her to get out of here or she might lose her head!... Mother dropped her spoon. Mr. Janczewski got up, took her hand and immediately escorted her out. Without looking back, they got into the car and drove away. - Like they hadn't had enough! - Mr. Janczewski said. - They want more! Like they hadn't made a pile..." ${ }^{12}$.

It was not just a literary vision of the postwar reality. In the text entitled $\mathrm{Tu}$ już dla was nie ma miejsca [There is no Longer Room for You] Alina Cała and Helena Datner-Śpiewak wrote about various cases of murders on Jews in 1944-1947 and estimated the number of victims to exceed a thousand. Among the murders based on political and financial reasons committed by the military (e.g. by NSZ - Narodowe Siły Zbrojne [National Armed Forces]), they are singling out the ones that were committed by "ordinary civilian citizens. We can assume that they were often the former neighbors and the new owners of the so-called postJewish property [...]" ${ }^{13}$. In source materials collected by the authors we see cases of murders and assaults from various towns. In a report by Central Committee of Polish Jews from April 1945 from travels in the Tarnów and Rzeszów Voivodships there is a story of Chaim Fajgenbaum from Swoszowa, who survived with his family by hiding in a forest. When the Fajgenbaum family returned to the village in 1945, their home was already seized. The militia did not help, only a commander of a troop of the Red Army stationed nearby was able to force the peasant to give the home and the farm back to the owner. There were consequences: "On the second day of April of the current year, Fajgenbaum's home was shot at from machine guns. It resulted in Fajgenbaum's 13-year-old daughter being badly injured and having to be rushed to the hospital in Tarnów" 514 . In April of 1945, the Central Committee of Polish Jews has also noted a story of twenty Jews from

511 H. Grynberg, Zwycięstwo [Victory], Wołowiec 2001, p. 139.

512 Ibid., p. 196.

513 Dzieje Żydów w Polsce... [History of Jews in Poland], p. 16.

514 Ibid., p. 26. 
Rejowiec, who were saved from Auschwitz and returned to the town. "After staying there a few days the Jews received letters with threats demanding them to leave Rejowiec at once. Not wishing to take a chance against those threats, the Jews left and now reside in Chełm in the home of the [Jewish] Committee"515. In turn, the bulletin of the Jewish Press Agency reported that a "former resident of this town, Weinstock" was murdered in Przeworsk and in Kamieniec (actually Kanińsk) "7 Jews from the total of 16 living there" ${ }^{\text {"16 }}$ were killed.

And so, even if people who lost their homes for many years have finally arrived at their doorsteps, in the best case scenario they were simply chased away, in the worst ones - they lost their lives. This is one of the reasons why the Jewish fear and lack of sense of security did not end along with the war ${ }^{517}$. If a survivor gave up on getting back his possessions in time and lived, he was forced to remedy his perpetual homelessness somewhere else.

\section{Response to a crisis - hiding place as a home}

Michał Głowiński wrote the following about a moldy and empty mansard at Srebrna Street in Warsaw, where he was hiding with his mother after leaving a ghetto: "We owe to those four walls with the paint peeling off of them the fact that we are not homeless, not condemned to swift and inevitable death"518. This is the crux of the matter - a hiding place is an ad hoc remedy for the disease of homelessness which cannot be fully cured in conditions of occupation.

The wartime compulsory homelessness of the Jews, threat to life and a need to hide connected with it are signs of severe crisis affecting a society. A crisis is one of the basic phenomena attributable to human societies; it has impact on every dimension of human life. When we assume a perspective of the space transformed and organized by people for the needs of their social life, that process is subject to crises as well ${ }^{519}$. In the area, I am describing a crisis means losing a former home. The existing forms of architecture - other homes that one can inhabit - are now an incoherent form, unwieldy in satisfying needs. An ordinary home is not fit to accommodate people, as it is not providing security to the hiding people. Its normal use becomes impossible in light of the rigors imposed by the occupants.

515 Ibid.

516 Ibid., p. 30.

517 J.T. Gross, Fear...

518 M. Głowiński, Czarne sezony... [Dark Seasons...], p. 77.

519 J. Kaczmarek, Podejście geobiograficzne... [Geobiographical Approach...]. 
In psychology of architecture there a few solutions to a crisis of a given architectural form:

- transformation of that form;

- moving to a physical space that satisfies the needs;

- defining the rules of that space's functioning anew.

Opting for a hiding place means choosing the first solution (when people build crannies in a home, superimposing the form of a hiding place over a form of a home) or the second one (when people look for a different place to become their shelter).

The previously quoted Katarzyna Kasjanowicz formulated a concept of a surrogate home and listed its characteristics. The first one is the conventionality involving "establishing the role and giving identity to the place that is to take over the functions of a previous apartment. This process may appear to be the harder the less does that new space resemble a former home and the more it is reduced simply to the concept of a shelter" ${ }^{\prime 20}$. Another one is temporality, and the third is the constant sense of danger. Kasjanowicz lists a hiding place among examples of a surrogate home.

The author has also pointed out an important phenomenon - bringing items to a surrogate home. When crossing to the Aryan side, people would most often take valuable objects that were to be monetized. However, people would often make room in their luggage for objects that were valuable due to being filled with meaning, for example photos or tiny keepsakes. Those objects were "giving hope of having a permanent place to stay in the future. They were a connection between the prewar and postwar realities, the latter being the goal of every individual. But to get there one had to get through the experience of a surrogate home" ${ }^{221}$. Madeleine G. Levine presents similar thoughts in her text. Writing about a recurring figure of a surrogate home that people look for after losing their real one, Levine classifies Jewish hiding places as "the most degraded form of a surrogate home"s22.

By its very nature such a home cannot be presented in a positive way, as even though it performs minimum of a home's functions by giving a temporary shelter, it is unable to carry the whole weight of symbolical meanings that people ascribe to the idea of a home. Aside from a whole array of physical inconveniences

520 K. Kasjanowicz, Dom w getcie... [Home in Warsaw Ghetto...], p. 63.

521 Ibid., p. 74.

522 M.G. Levine, Bezdomność... [Homelessness]. 
and dangers, frequent changes of location stemming from the situation of outside threat were an important characteristic of hiding places that was clearly setting them apart from the stability of a home. Chana Finkielsztajn recalled: "I and my younger brother escaped to another village, 4 kilometers away from the previous one. We were alone for four days. After four days, we have laid down in a barn. That day our suffering began. We would wander around from the day we became homeless. We lived in atrocious conditions for 43 months. We suffered from hunger, cold and filth. We were facing death every single day. During that time, we have changed our location 52 times" ${ }^{23}$.

In Levine's analysis, the only bright images found in the texts are not connected with wartime reality: they appear in memories of the pasts and dreams about the future, even though Levine is skeptical to the idea of people burdened with baggage of cruel experiences creating an ideal home. The moment the hiding people start reminiscing about the olden days, they realize there being a profound chasm separating a real home and a hiding place. Memories of their family home are painful and heavy. Miriam Mariańska talked about that while describing her quest for furs. She got off on Czarna station between Cracow and Dębica, with Wygoda on the horizon. "I stood at the edge of the forest, leaning against a pine trunk, and looked at the snow-covered landscape of my youth with no tears in my eyes, the youth that started and ended here. From afar I saw the red roof of our home on the hill. Those meadows, now covered in snow, may still preserve my father's footprints. He used to walk them hundreds of times. Maybe there are footprints of our bare feet, from when we used to wade through wet grass in the spring, picking wild flowers. Those were not memories. They are memories now. Then, just few months after my family was displaced - as they now call the road to death in Bełżec - this was a living blood of despair, making the heart contract in the chest like a clenched fist. God, why did I come here? For the furs? This is all that is left from my parents' life's work in this world, on this land, which used to be their home, their life, their hope for peaceful old age! Plumes of smoke soar in the clear pre-evening air over the roof of my childhood home, over the roofs of all the farmhouses. The living are making supper. Time to go" 524 .

When we analyze the phenomenon of a hiding place as a surrogate home of the times of total crisis, we see that it is an amorphous and nonfunctional home, an area of suffering and tension. Yet for the hiding Jews their hiding place is

523 AJHI, 301/1284, Testimonies of Chana Finkielsztajn and Chalmida Michałko.

524 M.M. Mariańscy, Wśród przyjaciót i wrogów. Poza gettem w okupowanym Krakowie [Among Friends and Enemies. Outside of the Ghetto in Occupied Cracow], Cracow 1988, p. 88. 
the most hospitable place possible. I will now attempt to see a hiding place as a home, looking for tangents, similarities and characteristics, having in mind that even the best, most comfortable hiding place is still a place of deficit, limitations and enslavement for the people who live in there.

Looking at a home as a system (in a functionalist approach), we can see specialization of its various elements. The space of a home as we know it is divided into parts, and each of those parts has different functions: we prepare food in the kitchen, sleep in the bedroom, and take care of our physiological needs in the bathroom. A large number of hiding places, due to their limited surface and conditions, could not afford to maintain this division typical of a home. There were cases in which people were able to set up specialized rooms. Neider's hiding place, which was underground, had a chamber above ground, where they have organized a makeshift toilet (Neider calls it pisoir, from French) to avoid bad smell in the room where everybody spent majority of their time. Hence the underground room served as a bedroom and a living room, and the kitchen was located at the home of the hosts, who were sheltering Neider's group. The group with whom Stella Fidelseid was hiding in a tenement at Wołyńska Street during the Warsaw Ghetto Uprising and after it was finished was, for some time, in an even more comfortable situation ${ }^{525}$. "We had to think about food. We knew that there is a bunker in our home. It wasn't burned down yet, just destroyed, and there were food provisions there. [...] Hardtack, sugar, flour, peas and potatoes". They did not take all the food at once: "We have decided to go get the rest another time". Thus, the borders of the hiding place expanded: they have obtained a pantry. When they had to think about cooking a meal from the acquired goods, the time came to incorporate another room to the zone: "The only still usable place was the kitchen of the basement canteen. We went there the same way we did from the burning home. The hole punched a few days ago was now properly widened". Getting a kitchen has increased the area of freedom for the hiding people. They were able to move relatively freely in there, build a fire, prepare food. Stella used water accumulated in a tub to take a bath.

A specific case of specialization can be a symbiosis of a day-time hideout and another place, where one spends nights. The sixth hiding place of Stella Fidelseid was located in the attic of a tenement, where Stella lived before the uprising. Dynamism of the building, collapsing and flickering out after a fire, was creating new possibilities. "During the fire part of the roof fell on the rubble, creating a wavy, bent surface. At dawn, we could get under the tin of the roof and stay like

525 S. Fidelseid, Pozostatam w gruzach... [I have stayed in the rubble...]. 
that the whole day. Of course, there was no way we could move even the slightest, as crunch of the tin could give us away". The hideout was imposing harsh conditions: one had to quickly decide on a position for the next dozen or so hours, the ground was hard and it was cold, there was no chance for food, water, physiological needs, eye contact or talking. There was no way out. "If one of them [the Germans] were to move the tin, even unintentionally, we'd be doomed". All those restrictions were, however, only connected to the daytime. At nights, the group used to go to an apartment, which was only half-burnt in the fire. There were even beds with linen. They were switching from staying motionlessly under the sheet of tin and sleeping in a bed like in the old times, not astounded by those changes and adapting them to the rhythm of day and night.

However, it seems that specialization of the rooms of a hiding place is not a prerequisite of it being compared to a home. Moreover, a "the present, internal layout of the house [...] is quite recent" ${ }^{226}$. It being divided into separate spaces for sleeping, eating, and bathing does not have to be a main feature of a home. A hiding place can be compared to a home in its oldest, most primal understanding, when human needs were not as numerous and elaborate as they are today and when there were not so many ways of satisfying them. (Or a stay in a hiding place would mean degrading to the status of an extremely impoverished man who has nothing and lives in a burrow). When looking for that primal definition of a home, we can invoke the notion of territory I used in Chapter 2. According to environmental psychology, a territory is often connected with the notion of a home. Augustyn Bańka wrote: "Value of a territory in life of an individual can be best seen on the example of that individual's attitude towards home. A home gives a sense of security (physical and psychological) and comfort. It also creates a hospitable environment in which the one who possesses the territory can control and use sensory stimuli" ${ }^{22}$. A notion of a territory is borrowed from biological sciences, from observing behavior of animals protecting their territory and carefully establishing the boundaries of their homes. A hiding place, just like a home, is a kind of territory. They are both in the category of primary territories (there are also secondary and public ones ${ }^{528}$ ), meaning that people spend majority of their time there, they are characterized by exclusivity, and they

526 E.T. Hall, The Hidden Dimension, pp. 103-104; Philippe Ariès wrote about this as well in his Centuries of Childhood. A History of Family Life, trans. R. Baldick, New York 1962.

527 A. Bańka, Społeczna psychologia... [Social Environmental Psychology...], p. 161.

528 See I. Altman, The Environment and Social Behavior: Privacy, Personal Space, Territoriality and Crowding, Monterey 1975. 
should be controlled the most. An observation made by Stefan Ernest is a good summary here. He has extended the notion of a home to an uninhabited space of the emptied Warsaw Ghetto, presenting the point of view of a "squatter" with no right to be in the ghetto: "Squatter' is not going anywhere, 'squatter' couldn't care less about all the prohibitions. 'My home is my castle' - that's what a 'squatter' believes, thinking about his hidden nest - in the whole of the former district, in the big and small ghettos" 529 . An important note about threshold conditions that this territory had to meet: the physical size. To be compared to a home, a hiding place has to allow for at least minimal freedom of movement. Just like in the poorest, smallest hut of a pauper one can go from one chamber to the other, sweep the floors or prepare food, work during the day and lay at night, there has to be enough space in a hiding place, which is to be a surrogate home, to not only sit or lie down, but also to get up, bustle about, move something around. An attic, shed, basement, bunker, and a dugout can qualify to be surrogate homes. Wardrobes, barrels, sheets of tin - not really. It is hard to pinpoint a terminal point in this continuum of spatial forms of the hiding places we know about - yet we can get close to that point by comparing the ones located at the ends of the scale.

Perhaps, a hiding place will never be a home, as it is always temporary, it is not "mine", it is impossible to experience intimacy in there. Therefore, it cannot meet the criteria, which - when describing the phenomenon of a home - I have listed in the beginning of this chapter. There is no rootedness in a hiding place. There is no security. There is no time nor conditions to "embody a home". However, in some testimonies I have found records of moments when the people hiding felt that a hiding place is their home. It is usually a moment of a fleeting mood, when the hiding people suddenly feel a "homey atmosphere". Emergence of the atmosphere has little to do with the characteristics of the space of a hiding place. So what conditions accompany such declarations?

It would seem that a hiding place can be seen as a home, even if just for a moment, when it satisfies some higher-level needs, in some way special in the wartime conditions. On the one hand, we have the need of human warmth and at least minimal social rootedness that can be satisfied by presence of friendly people (family, loved ones) and good relations with them. That aspect of "homeliness" of a hiding place is illustrated by occurrence of waking up confused (I wrote on this subject in Chapter 2 as well) and "finding oneself" thanks to presence of a loved one. $21^{\text {st }}$ November 1942 Landsberg wrote: "I open my eyes - it's dark. The darkness is deep, dense, and black like shoe polish. Where am I?! My

529 S. Ernest, $O$ wojnie... [About the War...], p. 344. 
left hand encounters something slimy and cold. Burr! With my right hand I feel a steadily moving chest. It's Rudy! I'm finally 'home'. I reach to my pocket to get the matches, light the candle. The candle lights up, I close and open my eyes, gradually getting used to the light" ${ }^{330}$.

On the other hand, "homeliness" of a hiding place appears when the hiding people become aware of the sense of security that a hideout still gives them, strengthened by the contrast with the hostile world. With the enormous amount of dangers waiting for them outside, a hiding place is at least a familiar and domesticated space. Chaim Icel Goldstein wrote about such a situation. Members of the quest to find a better place in the ruins of the demolished Warsaw would go back defeated to their bunker. However, aside from disappointment, there were positive feelings as well: "The longer we walked, the closer we were to the bunker, the stronger the feeling of content would become, I would say - almost joy of being back to our own home. The dark hideout was now a safe haven for us. It was our anchor, our shelter, where we had domestic warmth waiting for us, where our loved ones, whom we wanted to see again very much, were waiting for us" ${ }^{\prime 31}$. Artur Schneider, who escaped to a forest after dramatic experiences in a ghetto in Dubieńka, was at first trying to get used to the new situation, by telling himself: "This is my home now. [...] I have to get used to it and get settled" 532 . Later he felt how much his new hiding place - in the quiet woodland surroundings - differed from the dangerous, crowded and turbulent places where he used to stay before. He chose one of "the deep overgrown pits" among the trees. "I gathered some grass and moss. In one of the pits, well masked by the shrubbery, I have arranged a base coat of branches, put moss and grass on that and had a bed. When the sun was at its highest I have gone to an open space to warm up a bit. Sun doesn't give much warmth in October, but for me, freezing and soaked, and after the experiences of the last few days, staying in a quiet forest on a sunny clearing seemed as if I was resting in a cozy room with a warm furnace"533.

An extremely important element of "domestication" of a hiding place recurring in numerous texts is a presence of typical household objects and carrying out domestic activities. The stage of "making a home" is equally crucial. Companions of Chaim Icel Goldstein experienced some joy when they were furnishing their basement bunker. Daniel managed to find a carbide lamp in another room, others got some food. Jechezkiel built a field kitchen out of two bricks

530 AYV, 033/1099, Journal of M. Landsberg.

531 C.I. Goldstein, Bunkier... [Bunker...], p. 93.

532 A. Schneider, Jak ścigane... [Like a Hunted...], p. 125.

533 Ibid., p 126. 
and some pieces of iron. "That very night we were eating our first supper since we went into hiding. Is it possible to be as happy as we were that moment? Ignac was even joking around as we ate, 'lecturing' Icchak for not bringing salt. 'When you go to a Jewish house warming party - he said - you have to bring salt'. We laughed. And so we spent the time in good moods till the morning came" 534 .

New furniture arrives to a "homey hiding place". Chaskiel "made a table and a bench from the boards he used to bring to the bunker for firewood. First, he knocked the nails out of the boards with a rock, then he nailed two of them wide sides together, and finally nailed them to the vertical elements - and the table was ready. He made a bench in a similar way" ${ }^{35}$. Similar activities and positive feelings connected with them were described by other authors. Florian Majewski in his text mentioned preparing a place to sleep. When he prepared a lying area and put makeshift bedding on it, he became relaxed: "For the first time in a long while I felt truly safe" 536 . Among items with almost magical power of creating a home a lamp is repeatedly mentioned. Menachem Katz directly calls his hiding place a home $e^{537}$ - as he found it himself with other members of his family, they have furnished it themselves and have a symbol of a home: a kerosene lamp. Goldstein also wrote about a carbide lamp calling it a "treasure" and "good omen".

Other manifestations of domestication of a hiding place include various typically domestic activities performed inside. Neider wrote in detail about cleaning that had to be done in a hiding place (a concrete basement connected with a "chamber") after a flood struck and the basement was filled with rising waters of Prut River. It is a team work - carrying things upstairs to dry, taking out rotten straw from bunks, "wiping ash, mold. I have installed and electric cooker and dried some wet parts of the wooden wall, bed frames and even concrete with that" ${ }^{\prime 3}$.

Cooking is an activity performed only in the most independent hiding places - in majority of assisted hiding places, especially those "under one roof", already prepared food was provided by the hosts. Preparation of a meal and dining

534 C.I. Goldstein, Bunkier... [Bunker...], p. 25. In the quoted fragment there is even a word "happy". However, we have to take into account the time of creation of Goldstein's text - it is highly likely that years later the author recalls his past to be more optimistic. At the same time, it is hard to find such enthusiastic descriptions in texts written during or just after the war.

535 Ibid., p. 55.

536 F. Majewski, Pustelnik... [Hermit...], p. 68.

537 "We easily got settled in our new home" (M. Katz, Na ścieżkach... [On Paths...], p. 226).

538 AYV, 03/2076, Memoirs and journal of C. Neider. 
together combine a few important elements: presence of fire, warmth, food, which is the source of life, tastes and smells, and finally a deeply rooted archetype of sharing a table with other people, which symbolizes a community comparable to family. Preparing food in a hiding place was usually a tough and complicated chore generating conflicts. In the testimonies there are, however, descriptions of instances when this activity was creating an atmosphere of warmth and coziness typical of a home: "When we slipped inside, Ignac and Icchak were already there. They got luckier than us, they found valuables: a sack with a few kilograms of flour, some barley groats and beans. Everybody was pleased. They were sitting by the fire where the meal was being cooked. Steam was puffing from the pot, and the smell of barley was hitting the nose. The meal was ready and they were only waiting for us. When Chana saw us, she immediately started setting the table. It got idyllic in the bunker" 539 . Another time Goldstein mentioned receiving guests in the bunker - their neighbors, who were hiding in the sewers nearby. Chana was serving soup and flans. "The steam was spreading throughout the bunker, giving the place a homey ambiance. [...] We felt as if a family gathered by a holiday table" ${ }^{340}$. The spirits were lifted in a similar manner by preparing a meal together in a story of Chaja Sojka Jabłonka, who was hiding in the Białystok ghetto. In the autumn of 1943, the group of people hiding in a large bunker managed to find a sack of flour. This remarkable find boosted the hiding people to action they hid in an abandoned bakery nearby and baked bread for everybody. "The work is going smoothly and swiftly. Five sets of hands are nicely kneading the dough. The fire is joyously sparkling and cracking, it's sort of brighter than in the good times. People are blushing and feeling more confident, even cracking jokes. 'I don't care about the Germans...' - Lachowicz says with a wide adorable smile. 44 round breads are placed on long and narrow boards. They are waiting to be put in the furnace. [...] Everybody is impressed by our bravery and idea to bake the bread. They greedily soak up the appetizing smell of fresh bread"541.

Looking for domestic characteristics of hiding places I have focused on tracking down the few descriptions of positive feelings and friendly, warm atmosphere in the testimonies. Meanwhile the essence of a home is not only captured by the idyllic moods. It is worth noting that the texts quoted above were mostly created many years after the war (memoirs by Majewski, Goldstein, Katz, Schneider),

539 C.I. Goldstein, Bunkier... [Bunker...], p. 55.

540 Ibid., pp. 56-57.

541 C.S. Jabłonka, Nasz bunkier w getcie białostockim [Our Bunker in the Białystok Ghetto], in: Księga Żydów ostrołęckich [Book of Ostrołęka Jews], Ostrołęka-Tel Awiw 2002, p. 410 . 
and perhaps the authors compared their hiding places to homes and presented almost idyllic images for the sake of a stylistic device, romanticizing the wartime reality many years later. Nevertheless, similarities between a home and a hiding place do not have to necessarily be searched for on the plane of assigning different values to the occupied space. The convergence is in the idea of an apartment itself. It is in a way very similar to the idea of a hiding place. Both an apartment and a hideout are places where people hide from the world, where they can be safe. When we close the door of a home, we symbolically and practically disappear from society; and vice versa: the outside world is out of our sight. A home is an individual space which differs from the public sphere. A hiding place is also an individual space, even if for different reasons. It is a distorted model of a home, just like a home arrest or a room of a sick person on bed rest who does not leave the house and spends the whole time on a scrap of individual space.

This special kind of individual space appears and dominates the life of the hiding people when an outside situation takes away their right to function in public space. Let us trace the change of the essence of a city, town, village - human living environment in general - during widespread cases of hiding on the example of the Warsaw ghetto. In the first months of existence of the ghetto, the walled in district was still a part of the city. It was a social space: inhabited by a diversified group of people and still satisfying their life needs to some extent. There were shops, hospitals, community service points, offices, and workplaces there. It was possible to discern communal areas for all the inhabitants of the ghetto: streets, squares, public buildings, and private space: houses, apartments, rooms. In the testimonies, the space is not mentioned very often. People would write about cruelty the sorts of which they have never seen before, about abnormality of life, the suffering. Relatively unchanged elements are not noticed. People notice differences, not continuity. Only when the social space disappears people have to find the functions they need in the private space. Personal space of a hideout is the final stage of tightening of the space of a ghetto. From the moment of its creation, when the space for human activity got limited by the wall, through excluding successive streets, displacements, and sending people to sheds - we have reached a point when a human has just a little space more than his body occupies. Michał Głowiński wrote: "Whoever was locked up in the ghetto was subordinate to collective fate, and hiding on the Aryan side had let us say - an individual character. Here the scenery would also often mean a confined space, but different to the ghetto - people could hide in wardrobes, in 
the attics, basements, barns, among ruins, i.e. all kinds of places" ${ }^{342}$. Situation of suddenly finding oneself in an individual space would apply to the same extent to the people hiding on the territory of the ghetto. For them the outside world ceased to physically exist when the Jewish district got destroyed. The world on the Aryan side was out of reach for the hiding people, hence it ceased to exist as well - it was an inaccessible area, so it was useless to them. Only definitively abandoning a hiding place was a start for a reverse process: expanding one's territory and reclaiming the social space.

\section{Building, acting, sense of causality}

When summarizing the above-mentioned fragments of texts about household activities in a hiding place, we can conclude that cleaning, organizing, straightening up, modifying furniture, are all gestures taming the space and giving one a sense of control over it, creating new quality dependent on the will and activities of a hiding person. The same goes for constructing a hiding place, establishing a lifesaving place from nothing. It is one of signs of human protest against imposed conditions, an active resistance against annihilation planned by somebody else.

Building a hiding place is one of survival strategies, but it is more than that. One can protect life in many ways, there is a continuum of attitudes: from complete helplessness to unleashing incredible power and potency. This potency can be understood as a defense against the stigma of a Jew-helpless victim with no causative power. Elżbieta Czykwin ${ }^{543}$ invoked Erving Goffman and elaborated on the notion of a brand (stigmata). This notion can be used to interpret the phenomenon of building hiding places. Stigmatization and discrimination of Jews during the Second World War were a fact that Jews had to face. The ones who were resisting being treated as the bearers of the stigma imposed from above were doing so by their activeness. They were opposing the power of stigma by building their self-esteem. Czykwin wrote: "Self-esteem is connected with a sense of self-worth and power and, in this understanding, is an expression of potential self-realization capabilities of a person, group or a nation. [...] In this sense it is a condition, a chance for actualizing potential capabilities of groups and its members" ${ }^{\prime 44}$. No matter if we call the creators of the hiding place architects or builders - creation of the hiding places is significant for construction of their self-esteem. Despite extremely difficult circumstances those people are trying

542 M. Głowiński, Wierna opowieść [True Story], “Gazeta Wyborcza”, 25 March 2003.

543 E. Czykwin, Stygmat społeczny [Social Stigma], Warsaw 2007, p. 267.

544 Ibid., p. 267. 
to influence their own fate, are not limiting themselves to instinctive behavior (looking for temporary hiding places), but take rational, deliberate, planned action to defend themselves and others.

In Chapter 2, I have discussed objectification of one's own body by the hiding people (as a result of staying in a limited space and need to minimize life functions). It seems to me that the constructors of hiding places were rather confirming their subjectivity through their actions and activeness. Ryszard Cichocki wrote about regaining subjectivity through action ${ }^{545}$. Humanistic psychology and sociology are quite consistent here. Subjective action means influencing the surroundings, ability to achieve results in line with one's own expectations. Subjectivity is a coherent way of defining social environment and reacting to it. Conditions of being a subject include self-determination, i.e. the prevalence of inner motivations over outside factors; deliberate action; and the preservation of human identity ${ }^{546}$. In the case of the creators of hiding places, this pattern is confirmed: they act in accordance with their motivation despite outside factors; by choosing to hide "underground" they are also preserving a sense of their own identity, they are not hiding the fact that they are Jews, also from themselves. Autonomy of an individual means creating and pursuing objectives. The objective here is to survive and the action - building a hiding place. Another criterion of subjectivity is freedom of choice - constructors of hiding places choose: location of a hiding place, technique of construction, they are the ones creating conditions in which they are going to stay. Of course, a wartime situation is heavily limiting that freedom. A factor conditioning the subjectivity is a sense of causality ${ }^{547}$, which we can also call a control over environment. Kofta believed that individuals with a sense of causality can cause physical, social or psychological changes in their surroundings. They can choose techniques and tools to make those changes. Ability to make change has both a pragmatic (individual

545 R. Cichocki, Podmiotowość w społeczeństwie [Subjectivity in a Society], Poznań 2003.

546 See T. Tomaszewski, Człowiek jako podmiot i człowiek jako przedmiot [Human as a Subject and Object], in: Studia z psychologii emocji, motywacji i osobowości [Studies on Psychology, Motivation and Personality], eds. J. Reykowski, O.W. Owczynnikowa, K. Obuchowski, Wrocław 1977.

547 X. Gliszczyńska, Człowiek jako podmiot życia społecznego [Human as a Subject of Social Life], Wrocław 1983; J. Rotter, Generalized Expectancies for Internal vs External Control of Reinforcement, "Psychological Monographies" 1966, No. 80(1) (609); M. Kofta, Kontrola psychologiczna nad otoczeniem. Ramy pojęciowe teorii [Psychological Control over the Surroundings. Conceptual Framework of the Theory], "Psychologia Wychowawcza" [Educational Psychology] 1977, No. 2. 
possesses know-how and skills) and normative character (individual is allowed to make a change). Constructors of hiding places have know-how and skill and obtain the tools and materials themselves. As for the normative aspect - according to the laws in force it is of course not allowed to build hiding places, but their creators give themselves that right, thereby strengthening their sense of causality.

This sense of power and confidence accompanies builders of shelters. Florian Majewski with a "head full of plans" to build a bunker was "content and sure that [he is] going to make it" ${ }^{\text {"48 }}$. The hiding people who did not build their shelters from scratch, but made some place livable on their own, with their own hands, would also get that feeling. I found the following description in memoirs of Jan Kostańśki: “There was a water pipe in our basement. Maybe there's a draft? We sawed through the pipe, brought an iron cooker from that other home, hooked it up - there's a draft. We brought doors from the homes that didn't completely burn down, placed them on support legs made of bricks and we had bunks. We organized a table the same way. We put mats, rugs and carpets we scored on the concrete. We even brought a toilet bowl with a seat. We owned Warsaw"549.

\section{A few practical matters}

What conditions does a shelter have to meet to be good? What did its builders have to remember? I will try to briefly present a catalogue of engineering issues that the wartime Jewish architects had to face. It will give us some idea about what survived in those extreme conditions from the universal art of construction and idea of building a home. What proved to be fundamental and what was just an ornament?

In the beginning, we have to stress the difference between hiding places employing already existing elements of architecture, which are created when those elements get adapted, and those hiding places which were built from the ground up. All kinds of hiding places at one's own home, at somebody's home, in abandoned or destroyed buildings fall within the first category. At the opposite ends of the scale, we will have permanently sealed rooms, attics or basements and complicated constructions created in apartments with double walls, special corridors, entrances to disused furnaces, bunkers under floors. Homes, ruins, sewers and basements in the abandoned Warsaw Ghetto (and later in destroyed Warsaw) are a specific example - people hiding here had an enormous abandoned space at their disposal, with countless hiding places that were often formed after

548 F. Majewski, Pustelnik... [Hermit...], p. 65.

549 J. Kostański, H. Grynberg, Szmuglerzy... [Smugglers...], pp. 125-126. 
old constructions collapsed. Shelters in forests, in turn, were built from scratch: people would construct simple shacks or boxes out of branches. Dugouts were offering more secure shelter.

The first challenge for a constructor of a bunker was to choose a spot for a hiding place. Choose in a broad sense (city, countryside, forest) and in the narrow sense (one or the other basement, clearing). While the broadly understood location of a hiding place was often conditioned by a variety of factors impossible to list, a specific place was chosen in a significantly more pragmatic manner. A spot had to "be suitable", i.e. provide for the easiest construction works possible, be well-located, hard to find. Soil was important when creating dugouts. It had to be easy to dig in that soil, but it should not slide or get dank.

The second challenge is the idea how to build, which often expanded into an elaborate design. Preparing it required at least rudimentary technical skills, or at least a highly developed practical sense. Florian Majewski said: "I sat at the table with Marian and explained why I have decided to build an underground bunker. I drew everything on a piece of paper. [...] I have worked everything out in the tiniest detail, including what I was going to need for cooking, bathing, heating and ventilation" ${ }^{350}$. When it was decided exactly where the hiding place is going to be located, its size became an important issue. An anticipated number of people that were going to hide there was relevant along with technical capabilities, which were different each time. We know that a hiding person would like to occupy as little space as possible. Stella Fidelseid wrote: "I looked around to find shelter. Nearby there was a small tin barrel flipped upside down. If I could only fit under it!" 551 However, when building a hiding place that was to serve for an extended period of time, a size that would make the stay inside easier had to be considered.

A construction had to have basic elements, even if in their most primitive shape: roof, walls, floor, entrance. It had to be sound and withstand heavy rain, snow, various unforeseen events. It was easier in case of a shelter that employed a preexisting construction of a home and harder in case of a dugout. Obtaining materials was important: in a city one could get bricks, lime, and cement from a secret demolition or simply buy it. In a forest timber was the primary building material, and the main elements of a dugout structure were the walls and the bottom of a hole dug in the ground.

550 F. Majewski, Pustelnik... [Hermit...], p. 66.

551 S. Fidelseid, Pozostałam $w$ gruzach... [I have stayed in the rubble...]. 
Masking the shelter was the most important of the planned technical solutions. In case of hiding places in a home or any other building it was pertinent to hide the entrance and to mask a change of the shape of the room (if, for example, there was a double wall installed). Entrances to hiding places were masked in various ways. Guta Szynowłoga-Trokenheim was hiding in a basement-based shelter. The lid of the entrance was covered with a carpet and a table with an additional chicken pen underneath ${ }^{552}$. Edward Fitelberg from Warsaw mentioned the following in his account: "A basement from 30 Zamenhofa to 22 Gęsia Street was my bunker. It consisted of 3 rooms, was not connected with the rest of the basement and was blocked with crates. We have put up a brick wall, dried it with coke fueled space heaters and daubed it like the one of the basement where a hatter's workshop used to be. There was an ironing furnace there. We blocked the wall with that furnace and made a brick lid in the wall. It was leveled with the wall. The lid was very heavy. We have attached metal rails to the lid and we could easily take it off from the basement"553. Entrance to basements at 38 Świętojerska Street was masked as described below: "Mirski rolled the machine on top of the lid and scattered loads of feathers around" 554 . In the basement itself, the entrance was guarded by the following construction: "Entrance to the shelter was masked by a so-called cart. It was a slab from a reinforced concrete wall. We put bricks in front of it. The wall was attached to rollers on 2-meter long rails. After everybody went into the basement the "crate" was slid to mask a $170 \mathrm{~cm}$ long and $80 \mathrm{~cm}$ high entrance hole located at the base of the cellar floor" ${ }^{35}$. In woodland hiding places, people would cover the dugouts' roofs with moss and branches and the entrance with a bush or a boulder for camouflage.

Problems with organizing a kitchen, provisions and access to water would mostly affect independent hiding places (Goldstein talked about searching for water in destroyed Warsaw and Majewski dug his own well next to a dugout). Each hiding place had to have at least minimal access to fresh air. When building a hiding place people would leave a small window-like hole, a crack in a wall or (in dugouts) create an elaborate ventilation system out of tubes.

The popularity of building shelters is worth noting, especially since it was not an easy task, considering the dangers of such endeavor, supply difficulties, and required personal effort. It was more likely to find a professional to work on the construction in cities. In Warsaw, when the ghetto got a shelter-building fever,

552 G. Trokenheim-Szynowłoga, Życie w grobowcu... [Life in a Tomb...].

553 AJHI, 301/1308, Testimony of Edward Fitelberg.

554 L. Najberg, Ostatni powstańcy... [Last Ghetto Insurgents...], p. 54.

555 Ibid., p. 55. 
there were some who knew better what they were doing than others. Edward Fitelberg wrote: "At some point the word got out that we are building a new bunker. I was asked to go to Lejkin's successor, Piżyc and some other people, including Aron Sztok, who built many bunkers in the ghetto. This man was young, talented and had great initiative in this field" ${ }^{256}$. Construction works were proceeding during the Warsaw Ghetto Uprising as well. Leon Najberg remembers Blumsztajn brothers, the bricklayers who took the job of expanding the shelter at 38 Świętojerska Street. Many shelters, including a number of them in Warsaw, were created thanks to organized outside help. Teresa Prekerowa wrote: "Demand for shelters is very high and created a sort of specialization of architects and builders cooperating with aid facilities"557. The author mentions architectural engineer Emiia Hiżowa and bricklayer Leon Bigdowski, who's created a hiding place in his apartment and in homes of his friends (Szymon Frejman, Janina Pękalska, and Jan Bobeszko).

In other cases, people resorted to employing local craftsmen, like the Schönker family did. Henryk Schönker wrote in his memoirs that his father concluded an agreement with a carpenter. The craftsman treated the order like a real job and the contracting Jew as a real client, with respect. "Father was happy with the job and paid the carpenter the requested sum. It was a nice man and I must say he really put in the work. After the payment, they sat by the table and drank tea" ${ }^{\text {"5 }}$. All of that happened calmly, as the bunker was prepared "just in case", not in a hurry. The carpenter additionally offered that he can take in the Schönkers at his place if there is danger. Therefore, he turned out to be not just a constructor of a physical hiding place, but also of a safe future, as he gave them not only his work, but also a promise of aid.

The situation in forests differed, as the constructors of the bunkers were on their own. Aleksandra Bańkowska established ${ }^{559}$ that majority of the dugouts was built by total laymen. Bańkowska mentions only two testimonies of construction with help of specialists: text by Józef (Josif) Elman ${ }^{560}$ and recollection of Artur Schneider, who cooperated with Jankiel, referred to by the author as "Engineer"

556 AJHI, 301/1308, Testimony of Edward Fitelberg.

557 T. Prekerowa, Konspiracyjna... [Conspiracy...], p. 181.

558 H. Schönker, Dotknięcie... [The Touch...], p. 117.

559 A. Bańkowska, Las jako miejsce... [Forest as a Place...].

560 Elman wrote: "The dugout [was] built up to building codes and safety regulations, according to security needs it had to have two exits and be well disguised" (AJHI, 301/511, Testimony of Josif Elman). 
and who used to build military shelters during the First World War ${ }^{561}$. In contrast, we know that a new generation of specialists developed during the war, learning by practice. Bańkowska mentions Gerszon Tobak here. He talked about fourteen dugouts he built (not counting the ones where he "just helped" in the construction $)^{562}$. The author also talked about the phenomenon of a group of builders from a civilian camp near Boryslav ${ }^{563}$.

Those amateur builders, building a hiding place with their own hands, sometimes needed at least a bit of help. Florian Majewski asked his friend Marian for some items he needed to build a fireplace (a plate and ventilation pipes) and Marian told him that the needed elements can be found dumped in the priest's garden. Marian has also supplied him with tools: "hatchet, axe, hammer, some nails" ${ }^{664}$. Bańkowska also stressed that the constructors of the dugouts "got the tools for the construction from peasants they knew. It was not always easy: Berl Turner says that nobody wanted to lend tools to his group fearing that they will be discovered and somebody will recognize the items" ${ }^{\prime \prime 65}$.

Finally, I wish to summarize my deliberations on construction with a thought on the character of the analyzed texts. When I was looking for examples of various technical solutions used by the creators of the shelters, I have noticed a certain pattern. In majority of the texts I have read descriptions of space of a hiding place are usually succinct and not very precise (in fact, I write about that in the introduction). But when it comes to building a hiding place by oneself, the authors devote more space for the descriptions. They are keen to present technical details about constructing shelters, dimensions in centimeters, they talk about the materials they used and the construction ideas they had. Descriptions in texts by Majewski, Katz, and Schneider can serve as an example here. In some texts, there are also drawings (I present them in the annex). It is phenomenal against the backdrop of general gaps in the discourse on space and perhaps an argument supporting the theory about particular relevance of the act of constructing a hiding place in experience of the hiding people.

561 A. Schneider, Jak ścigane zwierze [Like a Hunted Animal], Lublin 2003.

562 AJHI, 301/1850, Testimony of Gerszon Tobak.

563 A. Bańkowska, Las jako miejsce... [Forest as a Place...].

564 F. Majewski, Pustelnik... [Hermit...], p. 55.

565 A. Bańkowska, Las jako miejsce... [Forest as a Place...], p. 38. 


\section{Summary}

In Chapter 4, I have presented an overall concept of an analysis of a hiding place as a type of a surrogate home. I start with a short review of the idea of home and reference to findings of psychology of architecture, and later move on to deliberate the wartime fate of a home. By using the concepts of homelessness and marginalization, I endeavor to present war as a cause of homelessness of the Jews and describe the stages of the process of losing one's home. The idea of a surrogate home allows us to think about to what extent and how could the hiding places substitute a lost home during occupation. Finally, I conclude that experience of constructing a hiding place and furnishing it on one's own could have been of immense importance for the hiding people.

The construction of hiding places is a creative process intended to help people survive - but additionally unleashing power and potency in people reduced to a status of a helpless victim.

Małgorzata Melchior, in an article on the people hiding "at the Aryan side" in Warsaw district ${ }^{566}$ brought up a model of analyzing wartime destinies used by Alicja Rokuszewska-Pawełek. It is a model of trajectory known in qualitative sociology. A trajectory situation is an experience in which an individual partially or completely loses control over the course of that individual's life. This person's fate is shaped independently by potent factors and events. Concepts well describing a trajectory situation include disorder, chaos and suffering. Classics of qualitative sociology present two possible interpretations of a trajectory experience. According to Anzelm Strauss people affected by such a situation try to somehow cope, while Fritz Schutze believes that they rather go with the flow of events, considering the situation to be the fate that cannot be defeated. Małgorzata Melchior thinks - and I agree with her opinion - that the Jews building hiding places and actively looking for help are opposing the system and their situation in this manner, while fighting for themselves and survival. We can therefore consider their attitude to be a natural continuation of a trajectory situation, as understood by Strauss. In turn, if would like to assume Schutze's reasoning, we would have to perceive the active efforts of the hiding people as a counter-trajectory.

However, we look at the efforts of the constructors and seekers of the hiding places, we have to primarily see their immense determination in pursuit of their goal. It is even more remarkable when we look at the whole phenomenon in a wide social and historical context, noticing the isolation and marginalization of the Jews fighting for survival.

566 M. Melchior, Uciekinierzy z gett... [Escapees...]. 



\section{Conclusion}

My train whistles in the Moselle Valley and I see a winter landscape slowly moving before me. The evening's coming. People are walking down the road along the tracks. They are walking towards a village crowned with serene smoke. Perhaps somebody's looking at that train, a careless glance, as this is a freight train, one of many. They are going home, they don't need that train, they have their own lives, own concerns. As I'm looking at them going down that road I suddenly realize, as if it was so simple, that I'm here, and they are there. I'm struck by a feeling of immense physical sadness. I'm here, I have been here for months, and they are there. It's not only about the fact that they are free, I could say a lot about that. It's just they are there, the roads, hedges along the paths, fruit in the trees, grapes in vineyards are for them. They are just there, while I'm here. It's not just that I can't go wherever I want, no man can really go wherever he wants. I have never been really able to go wherever I wanted. [...] I'm on this train. I'm on it of my own free will, since I could have not been here. That's not the point here. It's a strictly physical sensation: I'm here, inside. You can be either inside or outside, and I'm inside. A feeling of physical sadness spreading inside me, nothing more.

Jorge Semprun ${ }^{567}$

Few years ago, when I was starting to work on this book, I knew only that it will be about social aspects of the experience of the Holocaust. Paired with fascination that accompanied reading successive testimonies of the time of the Shoah was the interest in the basic dimension of human existence - space where our lives take place. This trope led me to choose the subject of hiding places.

Selecting the testimonies with relevant fragments, I initially did not realize that I was plunging into such an extensive, deep and, in some areas, completely not studied subject. I was in particular surprised with the abundance of the material. At first, I was interested in the history of the Warsaw ghetto, read accounts and journals, systematizing the acquired information in my mind. When I have decided to cross the borders of Warsaw in my search and to devote special attention to the countryside, then scientifically neglected, the whole universe of completely unknown, fascinating testimonies has opened before me. When I was reading more of the texts I was getting an impression that each forest, each ruin, almost every tenement or a farm could have been - and perhaps even were - a hiding place in occupied Poland. To me the whole country started to look like a collection of places that could save life, places changed by choice, actions of a person looking for shelter. Every described case seemed different to me, and

567 J. Semprun, Wielka podróż [The Long Voyage], Warsaw 1964, p. 7. 
each hiding place unique. I had to somehow deal with this issue, organize the material, or my book would have ended up as being a collection of unrelated study cases.

Therefore, Chapter 1 was created to encapsulate dozens of individual fates in a more synthetic pattern. I have selected categories allowing me to describe any hiding place: duration, assistance or lack thereof, location of space, number of people hiding. As each case found its place in this typology, the "historical" ("factual") stage of my work has passed.

When the typological chapter was finished, it was possible to proceed to the most important part: the one with my interpretations. I was not striving to defend any hypothesis formed beforehand. In fact, I believe that such research attitude can be deceptive at times and lead to wrong conclusions with regard to the Holocaust. I had a different task - I wanted to get as deep as possible inside of the texts I was reading, put together the pieces on the subject-matter I was dealing with, look for common threads, identify some patterns. And, most of all - I wanted to describe the world of hiding places from a perspective that was obvious to me, and yet which was previously not taken up by researchers. The perspective of space, which I call upon in the title of my book and to which I return in every chapter made it that - or at least I hope it did - I was able to say something new about Jewish hiding places, to lead the reader through the path I walked myself when I was working with the testimonies - through undiscovered areas.

In Chapter 2 I was initially trying to fit Jewish hiding places (i.e. simple homes, attics, nooks and crannies transformed into mysterious places) into social topography of occupied Poland. I was looking for a level where they could be found in the spatial structure. Hiding places, born out of will to preserve life against all odds, were after all a protest against the system imposed by the Germans. It was a part of the illegal world, where people were to some extent trying to save their freedom, and not only life. Hiding people and the people helping them were taking part in this common work of resistance. Thus, hiding places became a new element of social space, as the moment they arose new relations between individual people and social groups were established.

Aside from positive interactions (known and described in literature), such as acts of heroic help, support or even silent permission, reading the texts has also brought me to numerous examples of negative, destructive relations. In addition to the obvious threat of being detected by the Germans, the hiding people dealt with threat from Poles on a daily basis. Therefore, Barbara Engelking was right when she wrote: "From the Jews' point of view [...], the war is not an experience of dyad [as in case of Poles, whose enemies were the Germans - M.C.T.s note], 
but of a triad - it is a situation of a conflict between them, Poles and Germans" ${ }^{\prime \prime 68}$. Jews needed Poles to survive (aside from the few Jews who survived in hiding places I call independent). The phenomenon of being dependent on Poles has also had its dark side - the helping Poles were giving the Jews life; they also had a power to take it: by throwing out of a hiding place, denouncing, depriving them of their livelihood through blackmail and theft, and ultimately - killing them. In this asymmetrical relationship between Poles living in space around the hiding places and the hiding Jews, the place of a hideout was fragile and specifically determined.

The marginalization of Jewish hiding places was their primary general characteristic. A hiding place was not violating social harmony as long as it remained in its place, in the sphere of mystery. Anything could have happened the moment a hiding place - a place ascribed to the shadows - emerged from the darkness. Usually the worst would.

In the first part of the Chapter 2, I have reached some bleak conclusions. Once again, also from the texts I have read, it appears that German laws were not the only thing denying Jews a place to live on the territory of Poland. Hiding places existed alongside - or even against - unwritten rules applicable in Polish society. They were not places which would be positively evaluated like for example stashes with weapons or "bolt-holes" of underground Poland's activists. Out of many layers of then gray area a hiding place could have been situated on the total margin, as a dangerous and primarily unwanted space.

Despite all unfavorable circumstances, hiding places were a living space for the Jews. Their life that was threatened and there were no guarantees of survival. Yet, it was the only available space in a given historical situation for somebody that wanted to survive and had no chance to leave the territory occupied by the Germans and did not decide to live among Poles "on Aryan papers". Thus, in the following part of Chapter 2, I have abandoned deliberations in macro scale, i.e. looking for a place to fit the "hiding place" piece into the jigsaw puzzle of social space. In a metaphorical way, led by words of the testimonies, I have tried to look into a hiding place. I have completely focused on the optics of the hiding people and attempted to describe an individual experience of the space of a hiding place from their perspective. I did not write much about human relationships in a hiding place, as I was primarily interested how the hiding people experienced space in which they lived. In the texts, I have found many meticulous, yet fragmentary descriptions of sensory experiences of that micro-world that had to be a substitute for all the wealth of the outside reality for the hiding people. Those

568 B. Engelking, Zagłada i pamięć... [Holocaust and Memory...], p. 23. 
descriptions lead me toward deliberations about the body in a hiding place. When we consequently look at the hideout from the perspective of space, it turns out that the essence of a hiding place is to ensure invisibility for the body - which is not yielding too easily.

I have transferred my deliberations from the world of physical experiences to the world of meanings. Human beings living in any space constantly interpret the surrounding world. They try to give meaning to every element of the reality to accept their existence and find their place among them ${ }^{569}$. Chapter 3 is devoted to meanings in space of a hiding place. Once again, just like in Chapter 2, the direction of the analysis leads us from the outside to the inside of a hiding place, and the field of vision is slowly becoming narrower. I begin with senses we can find while observing a hiding place using anthropological criteria we know - borders, direction, dichotomy of sacred and profane. This understanding confirms the conclusions from Chapter 4: negative evaluation of a Jewish hiding place.

When I run out of room for interpretations, I once again let the authors of the testimonies speak. Reading dozens of texts multiple times made me realize that there are some patterns recurring in narratives on hiding places. I was especially interested in metaphors repeatedly used in the sources: a hiding place as a grave, Noah's ark, desert island, besieged fortress... Authors of diaries and memoirs (as the metaphors mostly come from those sources) are putting indescribable events in simple words. I interpret it as bringing the ongoing evil to heel, invoking familiar language, roots of civilization, and organizing the bizarre reality they found themselves in by attempts to tame $\mathrm{it}^{570}$. Perhaps, those metaphors were coined having in mind the future readers, who would find it hard to imagine living in a hiding place? When I was deconstructing those metaphors, I was looking for real connections between hideouts and mentioned places. Each of them can be compared to a certain type of shelter. But there is one metaphor that perfectly describes all Jewish hiding places from the times of the occupation: metaphor of prison, which I call a metacategory. I was initially planning to place this analysis in line with the others, yet as I was descending deeper and deeper into a prison world (lead by memoirs by e.g. Vladimir Bukovsky and Adam Bodor) I was

569 An extender version of that claim is a sociological theory known as social constructionism (see. P.L. Berger, T. Luckmann, The Social Construction of Reality, Garden City 1967).

570 Social actors give sense to the reality that surrounds them, they want to bring order to that reality, create some models-metaphores. Karl Weick (The Social Psychology of Organizing, Reading 1969), theoretician of organization, called this process sensemaking. 
struck by how many aspects of a hiding place can be described using this metaphor. I have ultimately devoted significantly more space to this metaphor, hoping that it is justified by the depth and extent of its interpretation.

When considering this exact metaphor, I have found another, equally universal model of space constantly present in human life. This is how Chapter 4, enveloped around the notion of home was born. This interpretation has lead me in a bit different direction than deliberations from Chapter 4. I have found key words describing some fragment of Jewish experience. Notion of homelessness and marginalization connected thereto allowed me to once again present the difficulties encountered by the Jews fighting for survival. A status excluding from society of being sentenced to death was now accompanied by a status of a homeless person - in a way doubling that exclusion. Fight for survival has an economic aspect here - it is not enough to escape death and hide, one also has to survive. You need at least some financial resources to do so. I do not write about financial dependencies between the hiding and the helping, I only focus on a one thread, which I call "things and homes in hands of the neighbors". (This thread has recently resurfaced and came back to public discourse after Polish translation of Jan T. Gross's books, Fear and Golden Harvest were published. Despite attempts to have a fair discussion on the subject, it still remains a heavy taboo). From my point of view this is another highly painful stage of the Jews plunging into homelessness, which they could have escaped e.g. by their own actions. Jews taking matters into their own hands and attempting to create a hiding place for themselves - an ersatz of home - are breaking the pattern of complete dependency described above, the asymmetrical and dangerous tie to their Polish neighbors. By taking an active action they use help, but they still transform their status of "an object" that somebody agrees to hide (and by doing so this somebody becomes the ruler of their fate), into a status of a "person" who's trying to escape their situation of crisis on their own, as much as possible. A hiding place built (or furnished) on one's own becomes a "good-luck charm" of better fortune. Studying the sources from this angle hints that constructors of hiding places indeed use "homey" comparisons thus positively valuating their hideout. Therefore, Chapter 4 ends with a rather positive conclusion, showing a way of excluding hiding places from the negative patterns described above.

However, this exclusion probably takes place only in the consciousness of the hiding people. Nothing indicates it permeating into consciousness of the Poles, as the fact that Jews are preparing a hiding place themselves and fighting for survival on their own probably did not mean much. Thus, my book leads to a conclusion of more general nature: about social loneliness of the hiding people, who had nobody that would be truly on their side. Jews who survived thanks 
to the help from their Polish neighbors somehow appreciate that help, even if the price to pay for survival included humiliation, losing money, and violence, for it is hard to compare enduring even the worst things inflicted by the helping people with the fact that they were, after all, saving somebody's life ${ }^{571}$. But presence of that help did not always counteract loneliness of the people who got suddenly ripped away from their own (and any other) world, despite the fact that the life above their heads still went on. Those people had to fight for themselves, as nobody was thinking about them, nobody noticed them disappearing from the face off the earth, nobody missed them. I think that this loneliness and exclusion from the world can be made out from my description of storage-hiding places, where people would idly and silently spend their "days dragging on like centuries" contemplating patterns of stones or cracks between boards.

$* * *$

People are of the highest importance in our lives.

Jorge Semprun ${ }^{572}$

I think the most important conclusion that comes to my mind in the end is: a space without people cannot be described. First and foremost - we can only write using other people's words; everything we know about hiding places is mediated. Therefore, we cannot write about hiding places without mentioning the ones who hid there (since we assume their point of view using personal documents); the ones who helped there; the ones who posed threat to them. Without presence and actions of all the social actors, hiding places would be meaningless - they would not exist at all if it was not for the people who were looking for shelter. I write about that in Chapter 2, when I define hiding places as a social space which first of all is a social structure construct shaped in a particular historical moment; and secondly it is a creation of particular people (the hiding and

571 Barbara Engelking brings up a story of Berland spouses who were sheltered for a year by Zdzisio and Halinka - Poles from a completely different social class, who would "treat them abysmally, especially Halinka - she was cheating whenever she could, stealing at shopping and any other occasion. Berland's hosts were completely insensitive about their situation. They would spend all the money they got on alcohol, they could 'party' a few days in a row, and during that time the Jews had to stand motionlessly behind a double wall. Halinka and Zdzisio were awarded a medal of the Righteous. In an interview conducted in the 90s Mrs. Berlandowa said: 'They were scum, but they saved our lives' (B. Engelking, "Dolary skupuje, koty przechowuje”... [I buy dollars and keep cats]).

572 J. Semprun, Wielka podróż [The Long Voyage], Warsaw 1964, p. 29. 
the helping). I want to reiterate: I did not lose sight of the people living in hiding places even for a moment when I was looking at those places from the perspective of space.

In this context the mutual assistance between the hiding people - tangible and physical kind, but also emotional and moral support, seems to be an especially important aspect of existence of hiding places. It was what helped people survive in hiding. I also mean help in a spatial sense - sharing one's own place, acquired with such hardship, with somebody else. It means letting somebody into one's own hiding place, drawing them into a complex "ecosystem" that develops each time a group of people has to live in a defined space. It is also help "measured in centimeters". Jorge Semprun gives an example of such help (not in a hiding place, but in a train going to a camp) when writing about "a boy from Semur": "We have been standing pressed into one another for four days and three nights, his elbow in my ribs, my elbow in his stomach. I have to stand on one leg for him to properly put both his feet on the floor. He stands on one leg too for me to properly put my feet down and relax my shin muscles a bit. We gain a few centimeters and take turns resting"573. Without such gestures, without presence of somebody's warm, alive body next to us - or at least without a tender memory of the loved ones who are not there in a hiding place - it would be so much harder to survive.

$$
* * *
$$

That is the end of my analyses and interpretations. I am aware that despite the most empathetic study of the texts I am still skimming the surface of the phenomenon. Over several years I have somewhat metaphysically connected with my subjects, as I felt let in on an intimate part of their lives when I was reading their journals and testimonies. It was all the more sorrowful for me to know that many of them have not survived the war or lost their loved ones. Thousands of others have not survived either and have not even left one word behind. When I was studying the experiences of all the hiding people and thoroughly describing the space where they were attempting to save themselves, I was paying them a tribute the kind of which they have waited for till this day. As I wrote in the Introduction, when the framework of the discourse was set by the fight of historians for the supremacy of one of the Jewish attitudes toward the Shoah (passively agreeing to die contrasted with armed resistance), we forgot about silent everyday heroes, who were searching for their path between the extremes. For me such

573 J. Semprun, Wielka podróż [The Long Voyage], Warsaw 1964, p. 10. 
heroism meant living in a ghetto, caring for one's family, surviving day by day. I also believe each attempt to survive "on Aryan papers" to be heroic. It was like living in the middle of a stage in front of hostile audience, living for the price of "being somebody else" 574 .

I was trying to describe experiences of other heroes as well - the ones who have gone underground to survive.

As an epilogue to those deliberations, I would like to tell a story of a certain hiding place that was honored in an unusual way ${ }^{575}$.

Steinkellers family used to live in Biała. Jakub, the father, was born on $20^{\text {th }}$ February 1906 and worked in his own tin workshop. Sara, the mother, was born on $13^{\text {th }}$ September 1910. They had one son, Fryderyk. When the war began, the family was relocated to the Zawiercie Ghetto ${ }^{576}$. The parents probably knew that the displacement was coming soon. They were not looking to save themselves, but to place Fryderyk somewhere. Just outside the Zawiercie Ghetto, at 3 Nowy Rynek Street, Polish family of Nowaks lived on the second floor. There were six of them: Genowefa Nowak - mother, Władysław Nowak - father (worked in glass works in Zawiercie, fell ill and died in July of 1944), their daughters Rozalia and Wiesława (10 and 11 years old in 1943), aunt Maria Jakubowska and grandmother - Zofia Jakubowska. On the ground floor of that home there was a German workshop, where Jakub Steinkeller used to go to work from the ghetto.

Just before being relocated from the Zawiercie Ghetto ${ }^{577}$, Jakub asked Nowak family to keep his son safe. He was to go back for him in a few days, perhaps he found or built some secure hideout. He's never come back for the boy and died with his wife in Birkenau.

Fryderyk spent almost two years at Nowaks' - till the end of the war. 3 Nowy Rynek Street tenement was four stories high with eleven other families living inside. Nowaks were afraid of their neighbors they did not tell anybody (except

574 M. Melchior, Zagłada a tożsamość... [The Holocaust and Identity].

575 I wish to thank Alina Skibińska here for giving me invaluable information on this subject.

576 The Germans occupied Zawiercie in September of 1939 and incorporated it to the Reich, changing its name to Warthenau. In June of 1940, they have created an (open) ghetto in Zawiercie, where they imprisoned 10 thousand Jews.

577 In August of 1942, the Germans transported around 2 thousand Jews from the Zawiercie ghetto to Auschwitz; a similar number of people were employed to sew German uniforms. Liquidation of the ghetto was conducted in August of 1943 and then another 6 thousand Jews were sent to Auschwitz. Only a few hundred of people were left in the ghetto, to be later sent to Auschwitz in October of 1943. 
for Władysław Nowak’s sister) that they are keeping a Jewish child. Fryderyk, whom they called Januszek, spent a lot of time in a wardrobe (or behind it) on a tiny wooden chair. In February of 1945 he could leave his hiding place. He soon ended up in a Jewish orphanage. (His short testimony of hiding is located in the archives of Jewish Historical Institute, item no. 301/906). He is now called Ephraim Gat, and is an elderly man living in Israel.

Why do I bring up his story here? I was touched by pietism and affection given to Fryderyk - Januszek - Ephraim's hiding place. The wardrobe where he spent long days and months of the war is now a part of the collection of United States Holocaust Memorial Museum. Along with the tiny chair, it is a part of the Life in Shadows: Hidden Children and the Holocaust ${ }^{578}$ exhibition. We even know the precise specs of the wardrobe and the chair. "Three-door wardrobe, mirror on the middle part, three drawers at the bottom of the wardrobe, veneered, $1^{\text {st }}$ half of the $20^{\text {th }}$ century, measurements: 220 (width) $\times 225$ (height) $\times 70$ (depth) $\mathrm{cm}$. The widest part with the mirror (middle part) was $100 \mathrm{~cm}$ wide. Wooden chair, folding, $20^{\text {th }}$ century before 1945 , measurements $48 \times 27 \times 21 \mathrm{~cm}^{\text {"579. }}$. Ephraim Gat is also one of the characters in Aviva Slesin's film Secret Lives: Hidden Children \& their Rescuers during WWII (2002). An article by Reilly Capps, Life Support: A door to a dark time ${ }^{580}$ talks about a real or imagined Ephraim Gat's visit to the museum and emotions induced by seeing the wardrobe and the chair.

I was fascinated by that way of preserving a shred of history of the Shoah: by meticulously conserving an authentic place. Admittedly, the wardrobe was transported from Zawiercie to Washington, and therefore it was excluded from a valuable spatial context, but it was given an "eternal life" through being placed in a museum, a life filled with deep meanings. It became a symbol of all the wardrobes, nooks, and crannies saving people's lives. It is not just a wardrobe anymore, but a visible and tangible sign. In the apartment where it used to be it would probably be regarded as a regular old - and not antique - piece of furniture, maybe already due to be replaced.

From the deliberations on the fate of this extraordinary wardrobe my grief over thousand other wardrobes is born. People used to burn them in furnaces after the war, they used to burry bunkers and dugouts, blow up the ruins of tenements. I also grieve over the people saved by those places - even for a short time - whose stories are now completely forgotten.

578 You can see the exhibition online at http://www.ushmm.org/museum/exhibit/online/ hidden-children/index/.

579 From Alina Skibińska’s materials.

580 http://www.postgazette.com/lifestyle/20031015life1015fnp6.asp. 
Let my one wish be a confirmation of my intention to write about people through writing about space. I would like to contribute to some names being "discovered" thanks to my book. Among many authors, whose words I used to describe hiding places, some people left illustrious, exceptionally moving and opulent texts. I wish for their testimonies to be included into a wider discourse and to function alongside journals of Adam Czerniakow, Mary Berg or chronicles of Emanuel Ringelblum. These include texts remaining in archives, published in scientific magazines or even as books. The authors (mainly female) I would like to mention are Stella Fidelseid, Landsberg, Marceli Neider, Hinda and Chanina Malachi, Jochwed Kantorowicz, Zofia Dulman, Maria Koper, Etka Żółtak... Each of those stories adds new, often shocking details to our knowledge about the Holocaust. Each of them describes the time of the Shoah from a unique point of view, sometimes so vividly, as if a window to that world opened before the reader. Among other stories about hiding I know, which were perhaps more general, not so close to the reality, not written so lively and poignantly, those stand out in particular. By remembering and reminding ourselves about the authors of the stories we also commemorate all the others, the silent ones. Just like the wardrobe in the museum in Washington commemorates all the other, no longer existing places - the hiding places. 


\section{Bibliography}

Sources and fiction

Archives of Jewish Historical Institute, testimonies, unit 301

Anonymous: 6641

Bursztajn Pesach: 550

Cienki Mendel: 1437

Elman Josif: 511

Fabrycki Jakub: 78

Farfel Dawid: 6799

Finkielsztajn Chana, Michałko Chalmida: 1284

Fitelberg Edward: 1308

Gail Hersz: 6640

Genda Aron: 110

Gerstenman Rajzel: 487

Gertner [name unknown]: 13

Grabarek Helena: 5149

Herc Izrael: 1496

Hermanowicz Pinkas: 875

Kantorowicz Jochwed: 2493

Kawarski Leon: 981

Klein Marta: 12

Kopilewicz [Łejke]: 701

Leder Abram: 53

Lewin Szmul: 1163

Liberman Szmuel: 401

Łozowski Rachmiel: 540

Nussenbaum Szajek: 3003

Polisiuk [name unknown]: 5061

Resler Maks: 36

Rochmil Berta: 321

Rosen Samuel: 1935

Rubinsztajn Szloma: 874 
Schönberg Edmund: 2344

Steinem Mania: 3698

Szczyrba Mikołaj: 3684

Szlajcher Israel: 105

Sznajman Icchok: 16

Sztajnkeller Fryderyk: 906

Szwarc Josif, Josif Kogan: 505

Tobak Gerszon: 1850

Wajnberg Rywka: 1437 I

Wajnsztajn Dina: 1472

Wołkowicz Lipa: 6792

Żółtak Etka: 545

\section{Journals, Unit 302}

Grocher Irena, Diary: 103

Midner Helena, Diary: 161

\section{Archive of Yad Vashem, Unit O3}

Kenigswein Regina: 2888

Malachi Hinda and Chanina, Journal: 3379

Markiewicz-Boraks Bronisława: 2818

Neider C. [Marceli], Memoirs. Journal: 2076

\section{Unit $\mathbf{O 3 3}$}

Chiger Ignacy, Świat w mroku. Przebieg zmagań o życie [World of Darkness. Course of Struggle for Survival]: 3059

Koper Maria, Diary: 334

Landsberg M. [name unknown], Journal: 1099

\section{Other}

Rotszyld P., Memoirs, manuscript, no date

Szulamit [surname unknown], Wspomnienia pierwsze i ostatnie [First and Last Memories], manuscript in author's possession.

Interview with Wacław Iglicki, manuscript in author's possession. 


\section{Printed sources, fiction}

Abramow-Newerly J., Lwy z mojego podwórka [Lions from My Yard], Warsaw 2001.

Akavia M., Jesień młodości [Autumn of Youth], Oświęcim 1996.

Aleksandrowicz J., Kartki $z$ dziennika Doktora Twardego [Pages from Doctor Twardy's Journal], Cracow-Wrocław 1983.

Amiel I., Osmaleni [The Charred], Izabelin 1999.

Archiwum Ringelbluma. Konspiracyjne Archiwum Getta Warszawy. Listy o Zagtadzie [Ringelblum's Archives. Conspiracy Archives of Warsaw Ghetto. Letters about the Shoah], prepared by R. Sakowska, Warsaw 1997.

Aron I., Relacja [Testimony], in: Życie i zagłada Żydów polskich 1939-1945. Relacje świadków [The Life and Holocaust of Polish Jews 1939-1945. Testimonies of the Witnesses], eds. M. Grynberg, M. Kotowska, Warsaw 2003.

Arońska S., Relacja [Testimony], in: Życie i zagłada Żydów polskich 1939-1945. Relacje świadków [The Life and Holocaust of Polish Jews 1939-1945. Testimonies of the Witnesses], eds. M. Grynberg, M. Kotowska, Warsaw 2003.

Bauman J., Zima o poranku [Winter in the Morning], Cracow 1989.

Benjamin W., Berlińskie dzieciństwo około roku tysiąc dziewięćsetnego [Childhood in Berlin around 1900], "Literatura na Świecie" 2001, No. 8/9.

Berg M., Dziennik z getta warszawskiego [Journal from Warsaw Ghetto], Warsaw 1983.

Berland M., Dni długie jak wieki [Days Like Centuries], Warsaw 1992.

Białoszewski M., Pamiętnik z powstania warszawskiego [A Memoir of the Warsaw Uprising], Warsaw 2005.

Bierzyński-Burnett I., Po śladach pamięci. Walka o przetrwanie czasu Wielkiej Zagłady [Tracking the Memory. Struggle to Survive the Great Shoah], Warsaw 1995.

Birnbaum I., Non omnis moriar. Pamiętnik $z$ getta warszawskiego [Non Omnis Moria. Memoir of the Warsaw Ghetto], Warsaw 1982.

Blady-Szwajger A., I więcej nic nie pamiętam [And I Don't Remember Anything Else], Warsaw 1994.

Blatt T.T., Z popiołów Sobiboru (Skąd nie ma powrotu). Historia przetrwania [From the Ashes of Sobibór (There's No Way Back). History of Survival], Włodawa 2002.

Bodor A., Zapach więzienia [The Smell of Prison], Wołowiec 2004.

Brodski J. Mniej niż ktoś, in: J. Brodski, Mniej niz ktoś. Eseje, Cracow 2006.

Brodski J., W półtora pokoju, in: J. Brodski, Mniej niż ktoś. Eseje, Cracow 2006. 
Buczkowski L., Czarny potok [Black Creek], Warsaw 1965.

Bukowski J., Opowieść o życiu [About Life], Warsaw 2002.

Bukowski W., I powraca wiatr... [And the Wind Returns...], Cracow 1999.

Cain L., Une enfance au ghetto de Varsovie, Paris 1997.

Cain L., J'étais enfant à Varsovie, Paris 2003.

Camon F., Rozmowa $z$ Primo Levim [Conversation with Primo Levi], Oświęcim 1997.

Chaskielewicz S., Ukrywałem się $w$ Warszawie [I Was Hiding in Warsaw], Cracow 1988.

Chuwis-Thau L., A jeśli Cię zapomnę [And If I Forget You], Warsaw 2002.

Cunge E., Uciec przed Holocaustem [To Run from the Holocaust], Łódź 1997.

Czerniaków A., Adama Czerniakowa dziennik getta warszawskiego [Adam Czerniakow's Journal from Warsaw Ghetto], Warsaw 1983.

Diamant T., Relacja [Testimony], in: Życie i zagłada Żydów polskich 1939-1945. Relacje świadków [The Life and Holocaust of Polish Jews 1939-1945. Testimonies of the Witnesses], eds. M. Grynberg, M. Kotowska, Warsaw 2003.

Dichter W., Koń Pana Boga. Szkoła bezbożników [God's Horse. The Atheists' School], Cracow 2003.

Dimant I., Moja cząstka życia [My Piece of Life], Warsaw 2001.

Dłużniewska S., Pamiętnik warszawski [Warsaw Memoir], Warsaw 1964.

Dulman Z., Relacja [Testimony], in: Życie i zagłada Żydów polskich 1939-1945. Relacje świadków [The Life and Holocaust of Polish Jews 1939-1945. Testimonies of the Witnesses], eds. M. Grynberg, M. Kotowska, Warsaw 2003.

Dzieci Holocaustu mówiq... [Children of the Holocaust Talk...], vol. 1-2, eds. J. Gutenbaum, A. Latała, Warsaw 1993, 2001.

Dzieje Żydów w Polsce 1944-1968. Teksty źródłowe [History of Jews in Poland 1944-1968. Source Materials], prepared by A. Cała, H. Datner-Śpiewak, Warsaw 1997.

Dziesięć listów $z$ warszawskiego getta [Ten Letters from Warsaw Ghetto], prepared by Borzymińska, "Biuletyn ŻIH” 1984, No. 129/130.

Ernest S., O wojnie wielkich Niemiec z Żydami Warszawy 1939-1943 [About the War of Greater Germany and the Jews of Warsaw 1939-1943], Warsaw 2003.

Fater C., Aniołowie bez skrzydet [Angels without Wings], Warsaw 1995.

Federbusch-Ophir A., Relacja [Testimony], in: Życie i zagłada Żydów polskich 1939-1945. Relacje świadków [Life and the Shoah 1939-1945. Testimonies of the Witnesses], eds. M. Grynberg, M. Kotowska, Warsaw 2003. 
Fidelseid S., Pozostałam $w$ gruzach... [I Have Stayed in the Rubble...], "Nasze Słowo" 1947, No. 19(31); 1948, 1(32), 2(33), 3(34), 4(35); reprinted: "Kwartalnik Historii Żydów" 2003, No. 2(206), 4(408).

Fink I., Odpływający ogród [Ebbing Garden], Warsaw 2003.

Fink I., Podróż [Journey], Warsaw 2004.

Fogelman D., Pamiętnik pisany w bunkrze [A Journal Written in a Bunker], "Biuletyn ŻIH” 1964, No. 52.

Frank A., Dziennik [Diary], Poznań 1993.

Frydman H., W getcie i w ukryciu [In Ghetto and in Hiding], "Kwartalnik Historii Żydów" 2004, No. 209.

Frymet D., Relacja [Testimony], in: Życie i zagłada Żydów polskich 1939-1945. Relacje świadków [Life and the Shoah 1939-1945. Testimonies of the Witnesses], eds. M. Grynberg, M. Kotowska, Warsaw 2003.

Gedanken B., Ostrołęczanie w getcie słonimskim [Citizens of Ostrołęka in the Słonim Ghetto], in: Księga Żydów ostrołęckich [Book of Ostrołęka Jews]. Ostrołęka-Tel Awiw 2002.

Gerwic G., Relacja [Testimony], in: Życie i zagłada Żydów polskich 1939-1945. Relacje świadków [Life and the Shoah 1939-1945. Testimonies of the Witnesses], eds. M. Grynberg, M. Kotowska, Warsaw 2003.

Gildenman M., Relacja [Testimony], in: Życie i zagłada Żydów polskich 19391945. Relacje świadków [Life and the Shoah 1939-1945. Testimonies of the Witnesses], eds. M. Grynberg, M. Kotowska, Warsaw 2003.

Głowiński M., Czarne sezony [Black Seasons], Warsaw 2002.

Głowiński M., Wierna opowieść [True Story], "Gazeta Wyborcza” 2003, No. 25(III).

Goldstein C.I., Bunkier [Bunker], Warsaw 2006.

Groll M., Relacja [Testimony], in: Życie i zagłada Żydów polskich 1939-1945. Relacje świadków [Life and the Shoah 1939-1945. Testimonies of the Witnesses], eds. M. Grynberg, M. Kotowska, Warsaw 2003.

Grupińska A., Ciagle po kole [Still Round], Warsaw 2000.

Grynberg H., Dziedzictwo [Heritage], London 1993.

Grynberg H., Pamiętnik Marii Koper [Diary of Maria Koper], Cracow 1993.

Grynberg H., Drohobycz, Drohobycz, Warsaw 1997.

Grynberg H., Ojczyzna [Homeland], Warsaw 1999.

Grynberg H., Memorbuch, Warsaw 2000.

Grynberg H., Żydowska wojna. Zwycięstwo [Jewish War. Victory], Wołowiec 2001. 
Grynberg H., Prawda nieartystyczna [Non-Artistic Truth], Wołowiec 2002.

Guz L., Targowa 64 [64 Targowa Street], Warsaw 1990.

Hirszfeld L., Historia jednego życia [Story of One Life], Warsaw 2000.

Hoffman H., Z Drohobycza do Ziemi Obiecanej [From Drohobycz to Promised Land], Lublin 1999.

Holcman C., Opowieść sióstr Holcman [Story of Holcman Sisters], in: Księga Żydów ostrołęckich [Book of Ostrołęka Jews], Ostrołęka-Tel Awiw 2002.

Holzmann K., Ziemia bez Boga [Land without God], Wrocław 1947.

Horn M.H., Pamiętnik Żydówki [Jewish Journal], Toronto 1985.

Jabłonka C.S., Nasz bunkier w getcie białostockim [Our Bunker in the Biatystok Ghetto], in: Księga Żydów ostrołęckich [Book of Ostrołęka Jews], Ostrołęka-Tel Awiw 2002.

Jadwiga, M., Wywiad [Interview], http://www.zydzi.lubaczow.pl/index. php?kat=wspomnienia\&id=3.].

Jagur O. (Grodzińska I.), Bunkier "Krysia” ["Krysia” Bunker], Łódź 1997.

Jaworski M., Plac Muranowski 7 [7 Muranowski Square], “Biuletyn ŻIH” 1974, No. 90.

Kałowska S.R., Uciekać, aby żyć [Run to Live], Lublin 2000.

Karpiński E., Wspomnienia z czasu okupacji [Memoirs from the Time of Occupation], "Biuletyn ŻIH” 1989, No. 149.

Karski J., Tajne państwo. Opowieść o polskim podziemiu [Secret State. Story about Polish Underground], Warsaw 2004.

Katz M., Na ścieżkach nadziei [On Paths of Hope], Warsaw 2003.

Katzmann F., Rozwiąanie kwestii żydowskiej w Dystrykcie Galicja. Lösung der Judenfrage im Distrikt Galizien [Solution to the Jewish Question in Galicia District], Warsaw 2001.

Kertesz I., Los utracony [Fateless], Warsaw 2002.

Klukowski Z., Dziennik $z$ lat okupacji [Journal from the Years of Occupation], Lublin 1958.

Korczak R., Płamia nad piepłom [Plamia over Ashes], in: Życie i zagłada Żydów polskich 1939-1945. Relacje świadków [Life and the Shoah 1939-1945. Testimonies of the Witnesses], eds. M. Grynberg, M. Kotowska, Warsaw 2003.

Kornblum W.D., Ostatnia latorośl [The Last Offspring], Warsaw 2000.

Kostański J., Grynberg H., Szmuglerzy [Smugglers], Warsaw 2001.

Lanckorońska K., Wspomnienia wojenne [Wartime Memories], Cracow 2001. 
Landau L., Kronika lat wojny i okupacji [Chronicle of Years of War and Occupation], Warsaw 1962.

Leisner R., A jednak cud się zdarzyt [The Miracle Happened After All], in: Losy żydowskie. Swiadectwo żywych [Jewish Fate. Testimony of the Living], vol. 2, eds. M. Turski, Warsaw 1999.

Levin A., Une coupe de larmes. Journal du ghetto de Varsovie, Paris 1990.

Lewin K.I., Przeżyłem. Saga Świętego Jura spisana w roku 1946 [I Survived. A Saga of Saint Yur Written in 1946], Warsaw 2006.

Lewycka M., Zarys dziejów traktora po ukraińsku [A Short History of Tractors in Ukrainian], Warsaw 2006.

Lubonja F., Nostalgia i ból [Nostalgia and Pain], in: Nostalgia. Eseje o tęsknocie za komunizmem [Nostalgia. Essays on Longing for Communism], eds. F. Modrzejewski, M. Sznajderman, Wołowiec 2002.

Ludność cywilna w powstaniu warszawskim. Pamiętniki. Relacje, Zeznania [Civilians in Warsaw Uprising. Memoirs, Testimonies, Statements], prepared by M.M. Drozdowski, M. Maniakówna, T. Strzembosz, Warsaw 1974.

Majewski F., Pustelnik [Hermit], Warsaw 2002.

Makower H., Pamiętnik z getta warszawskiego [Memoir from the Warsaw Ghetto], Wrocław 1987.

Margolis-Edelman A., Tego, co mówili, nie powtórzę... [I’m Not Going to Repeat What They Said...], Wrocław 1999.

Mariańscy M.M., Wśród przyjaciót i wrogów. Poza gettem w okupowanym Krakowie [Among Friends and Enemies. Outside of the Ghetto in Occupied Cracow], Cracow 1988.

Masłowska J., Relacja [Testimony], in: Życie i zagłada Żydów polskich 1939-1945. Relacje świadków [Life and the Shoah 1939-1945. Testimonies of the Witnesses], eds. M. Grynberg, M. Kotowska, Warsaw 2003.

Maciejewska I. (ed.), Męczeństwo i zagłada Żydów w zapisach literatury polskiej [Martyrdom and the Holocaust in Polish Literature], Warsaw 1988.

Meed W., Po obu stronach muru. Wspomnienia $z$ warszawskiego getta [On Both Sides of the Wall. Memoirs from the Warsaw Ghetto], Warsaw 2003.

Meroz A., W murach i poza murami getta. Zapiski lekarki warszawskiej z lat 1939-1945 [In and Out of the Ghetto Walls. Notes of Doctor from Warsaw 1939-1945], Warsaw 1988.

Michalson E., Relacja [Testimony], in: Księga Żydów ostrołęckich [Book of Ostrołęka Jews], Ostrołęka-Tel Awiw 2002.

Milch B., Testament [Testament], Warsaw 2001. 
Mróz K., Kozienice 1939-1944 (fragmenty dziennika) [Kozienice 1939-1944 (Passages from a Journal)], "Wieś Radomska" 1993, No. 4.

Najberg L., Ostatni powstańcy getta [Last Ghetto Insurgents], Warsaw 1993.

Najter S., Relacja [Testimony], in: Życie i zagłada Żydów polskich 1939-1945. Relacje świadków [Life and the Shoah 1939-1945. Testimonies of the Witnesses], eds. M. Grynberg, M. Kotowska, Warsaw 2003.

Neugebauer H., Łabieniec A., Gęsi puch [Goose Feathers], Toronto 2006.

Ney A., Pamiętnik [Diary], "Biuletyn ŻIH” 1989, No. 189.

Olczak-Ronikier J., W ogrodzie pamięci [In the Garden of Memory], Cracow 2001.

Pamiętniki z getta warszawskiego. Fragmenty i regesty [Journals from the Warsaw Ghetto. Fragments and Re-gestures], prepared by M. Grynberg, Warsaw 1993.

Pankiewicz T., Apteka $w$ getcie krakowskim [Pharmacy in the Cracow Ghetto], Cracow 2003.

Perechodnik C., Spowiedź [Confession], Warsaw 2004.

Potasz R., Relacja [Testimony], in: Życie i zagłada Żydów polskich 1939-1945. Relacje świadków [Life and the Shoah 1939-1945. Testimonies of the Witnesses], eds. M. Grynberg, M. Kotowska, Warsaw 2003.

Poznański J., Dziennik z łódzkiego getta [Journal from Łódź Ghetto], Warsaw 2002.

Reicher E., W ostrym świetle dnia. Dziennik żydowskiego lekarza 1939-1945 [Country of Ash. A Jewish Doctor in Poland 1939-1945], London 1989.

Rozenberg I., Relacja Izaka Rozenberga [Testimony of Izak Rozenberg], "Kwartalnik Historii Żydów” 2004, No. 211.

Ringelblum E., Kronika getta warszawskiego [Chronicle of the Warsaw Ghetto], Warsaw 1983.

Rosen S., My Lost World. A Survivor's Tale, London-Portland 1996.

Rubinowicz D., Pamiętnik Dawida Rubinowicza [Diary of Dawid Rubinowicz], Warsaw 1987.

Rubinsteinowa, Pamiętnik ze Lwowa [Diary from Lviv], "Biuletyn ŻIH” 1965, No. 61.

Ruch podziemny $w$ ghettach i obozach (materiały i dokumenty) [Underground in Ghettos and Camps (Materials and Documents)], prepared by B. Ajzensztajn, Warsaw-Łódź-Cracow 1946.

Schneider A., Jak ścigane zwierzę [Like a Hunted Animal], Lublin 1993.

Schönker H., Dotknięcie anioła [The Touch of an Angel], Warsaw 2005.

Semprun J., Wielka podróż [The Long Voyage], Warsaw 1964. 
Sierakowiak D., Dziennik Dawida Sierakowiaka [Journal of Dawid Sierakowiak], Warsaw 1960.

Sikora A., Szczęściarz [Lucky], Warsaw 1994.

Silverstein L., Tak właśnie było [That's What Happened], Warsaw 2002.

Sołomian-Łoc F., Getto i gwiazdy [Ghetto and Stars], Warsaw 1993.

Stasiuk A., Fado, Wołowiec 2006.

Symchowicz S., Pasierb nad Wista [Stepson at Vistula River], Warsaw 2005.

Szajowski E., Wspomnienia [Recollections], http://www.zydzi.lubaczow.pl/index. php?kat=wspomnienia\&id=1.

Szczypiorski A., Początek [Beginning], Poznań, no date.

Szelestowska M., Lubię żyć [I Like to Live], Warsaw 2000.

Szereszewska H., Józef i Hana [Józef and Hana], Warsaw 1993.

Szmidt L., Cudem przeżyliśmy czas zagłady [We Miraculously Survived the Shoah], Cracow 1983.

Szpilman W., Pianista [The Pianist], Cracow 2000.

Szynowłoga-Trokenheim G., Życie w grobowcu, Warsaw 2002.

Taubenschlag S. (Townsend S.), Być Żydem w okupowanej Polsce [Being Jewish in Occupied Poland], Cracow-Oświęcim 1996.

Tec N., Suche tzy [Dry Tears], Warsaw 2005.

Temkin-Bermanowa B., Dziennik z podziemia [Diary from the Underground], Warsaw 2000.

Ten jest z ojczyzny mojej. Polacy z pomoca Żydom 1939-1945 [This One is from My Homeland. Poles Helping Jews 1939-1945], prepared by W. Bartoszewski, Z. Lewinówna, Cracow 1969 [reissue Warsaw 2007].

Turkov I., C'était ainsi. 1939-1945. La vie dans le ghetto de Varsovie, Paris 1995. Tuszyńska A., Rodzinna historia lęku [Family History of Fear], Cracow 2005.

Wajbert I., Byt świat [There Was a World], Warsaw 1996.

Weiss S., Ziemia i chmury [Land and Clouds], Sejny 2002.

Wierciński E., Gałązki akacji [Acacia Branches], “Twórczość” 1947, No. 3(1).

Wiesenthal S., Stonecznik [Sunflower], Warsaw 2000.

Willenberg S., Bunt w Treblince [Rebellion in Treblinka], Warsaw 2004.

Wohlegelernter C.I., Relacja [Testimony], in: Życie i zagłada Żydów polskich 1939-1945. Relacje świadków [Life and the Shoah 1939-1945. Testimonies of the Witnesses], eds. M. Grynberg, M. Kotowska, Warsaw 2003.

Wojdowski B., Chleb rzucony umartym [Bread Tossed for the Dead], Warsaw 1981. 
Zawadzka H., Ucieczka z getta [Ghetto Escape], Warsaw 2001.

Żeromska M., Wspomnień ciąg dalszy [Memoirs Continued], Warsaw 1994.

Zimmermann H.Z., Przeżyłem, pamiętam, świadcze [I Survived, I Remember, I Testify], Cracow 1997.

Zimmermann-Gotterfeld Z., Pamiętnik Zosi [Zosia’s Diary], in: Przeżyłem, pamiętam, świadczę [I Survived, I Remember, I Testify], ed. H.Z. Zimmermann, Cracow 1997.

Życie i zagłada Żydów polskich 1939-1945. Relacje świadków, [The Life and Holocaust of Polish Jews 1939-1945. Testimonies of the Witnesses], prepared by M. Grynberg, M. Kotowska, Warsaw 2003.

Zylberberg M., A Warsaw Diary 1939-1945, London 1969.

Zylbersztajn S., A gdyby to było wasze dziecko?... [And What If It Was Your Child?...], Łódź 1994.

Zyskind S., Skradzione lata [Stolen Years], Warsaw 1991.

Żywulska K., Przeżyłam Oświęcim [I Survived Oświęcim], Warsaw 1946.

Żywulska K., Pusta woda [Empty Water], Warsaw 1963.

\section{Research papers}

Altman I., The Environment and Social Behavior: Privacy, Personal Space, Territoriality and Crowding, Monterey 1975.

Arad Y., Betzec, Sobibor, Treblinka. The Operation Reinhard Death Camps, Bloomington 1999.

Arendt H., Eichmann in Jerusalem. A Report on the Banality of Evil, New York 1963.

Arendt H., On Violence, New York-London 1970.

Ariès P., Images of Man and Death, Cambridge 1985.

Bachelard G., La poétique de l'espace, Paris 1957 (anonymous translation: http:// www.domowatmosfera.art.pl/opow0.htm).

Bańka A., Psychologiczna struktura projektowa środowiska [Psychological Design Structure of Environment], Poznań 1985.

Bańka A., Architektura psychologicznej przestrzeni życia. Behawioralne podstawy projektowania [Architecture of Psychological Life Space. Basic Behavioral Design], Poznań 1997.

Bańka A., Społeczna psychologia środowiskowa [Social Environmental Psychology], Warsaw 2002. 
Bańkowska A., Partyzantka polska lat 1942-1944 w relacjach żydowskich [Polish Partisans 1942-1944 in Jewish Accounts], "Zagłada Żydów” 2005, No. 1.

Bańkowska A., Las jako miejsce przetrwania Zagłady. Zjawisko ukrywania się Żydów w lasach w okresie okupacji niemieckiej w latach 1941-1945 na terenie II Rzeczypospolitej Polskiej [Forest as a Place of Surviving the Shoah. The Phenomenon of Jews Hiding in Forests during German Occupation in 1941-1945 in Second Polish Republic], master's thesis, Warsaw 2006.

Bańkowska A., Leśne kryjówki Żydów w okolicach Borysławia w okresie okupacji niemieckiej [Woodland Hiding Places of Jews Near Boryslav during German Occupation], manuscript, no date.

Baranowski B., Ludzie gościńca w XVII-XVIII w. [Highroad People in $17^{\text {th }}-18^{\text {th }}$ Centuries], Łódź 1986.

Berger A.L., Ashes and Hope: The Holocaust in Second Generation American Literature, in: Reflections of the Holocaust in Art and Literature, ed. R.L. Braham, New York 1990.

Berger A.L., Children of Job: American Second-Generation Witnesses to the Holocaust, New York 1997.

Berger P.L., Luckmann T., The Social Construction of Reality, Garden City 1967.

Bertaux D., Funkcje wypowiedzi autobiograficznych [Functions of Autobiographical Statements], in: Metoda biograficzna w socjologii [Biographical Method in Sociology], eds. J. Włodarek, M. Ziółkowski, Warsaw-Poznań 1990.

Bettelheim B., Individual and Mass Behavior in Extreme Situations, "Journal of Abnormal and Social Psychology" 1943, No. 38.

Bettelheim B., Surviving, and Other Essays, New York 1979.

Biberstein A., Zagłada Żydów w Krakowie [Holocaust in Cracow], Cracow 2001.

Bikont A., My z Jedwabnego [Us from Jedwabne], Warsaw 2004.

Czyński M. (ed.), Bioarchitektura - zagadnienia społeczne [Bioarchitecture - Social Issues], Szczecin 1992.

Czyżewski M., Piotrowski A., Rokuszewska-Pawełek A. (eds.), Biografia a tożsamość naukowa [Biography and Scientific Identity], Łódź 1997.

Bertaux D. (ed.), Biography and Society. The Life History Approach in the Social Sciences, London-Berkeley-Beverly Hills 1981.

Błaszczyk E., Strączek K., Wejść tam nie można [You Can't Go in There], Cracow 2005.

Boczoń W., Żydzi gorliccy [Gorlice Jews], Gorlice 1998.

Bogdanowicz P., Człowiek i przestrzeń [Man and Space], Warsaw 1988.

Brach-Czaina J., Szczeliny istnienia [Cracks of Existence], Warsaw 1992. 
Brach-Czaina J., Błony umysłu [Mind Membranes], Warsaw 2003.

Buczyńska-Garewicz H., Miejsca, strony, okolice. Przyczynek do fenomenologii przestrzeni [Places, Sides, Neighborhoods. Contribution to Phenomenology of Space], Cracow 2006.

Budzyński W., Miasto Schulza [Schulz's Town], Warsaw 2005.

Krajewski M. (ed.), Byli wśród nas. Żydzi we Włocławku oraz na Kujawach Wschodnich i w ziemi dobrzyńskiej [They Were among Us. Jews in Włocławek and Eastern Kuyavia and Dobrzyń Land], Włocławek 2001.

Caillois R., Żywioł i ład [Element and Harmony], Warsaw 1973.

Cała A., Wizerunek Żyda w polskiej kulturze ludowej [Image of a Jew in Polish Folk Culture], Warsaw 2005.

Calhoun J., Population Density and Social Pathology, "Scientific American" 1962, No. 206.

Calimani R., Historia getta weneckiego [A History of the Venice Ghetto], Warsaw 2002.

Camporesi P., Laboratoria zmysłów [Laboratories of Senses], Gdańsk 2005.

Caputa R., Jeziorski I., Okruchy pamięci. Z dziejów Żydów na Żywiecczyźnie [Crumbs of Memory. History of Jews in Żywiecki Region], Cracow 2000.

Charles A., Ishikawa S., Silverstein M., Jacobson M., Fiksdahl-King I., Angel S., A Pattern Language: Towns, Buildings, Construction, New York 1977.

Chomet A., Zagłada Żydów w Tarnowie [Holocaust in Tarnów], in: Zagłada tarnowskich Żydów [Holocaust of Tarnów Jews], eds. A. Pietrzykowa, S. Potępa, Tarnów 1990.

Cichocki R., Podmiotowość w społeczeństwie [Subjectivity in a Society], Poznań 2003.

Cichy M., Polacy - Żydzi: czarne karty powstania [Poles - Jews: Dark Pages of the Uprising], "Gazeta Wyborcza" 1994, 29-30 I.

Ciosek M., Psychologia sądowa i penitencjarna [Forensic Psychology], Warsaw 2001.

Corbin A., We władzy wstrętu. Społeczna historia poznania przez węch. Od odrazy do snu ekologicznego [The Foul and the Fragrant: Odor and the French Social Imagination], Warsaw 1998.

Czarnecki W., Podstawy urbanistyki [Basic Urbanism], Białystok 2002.

Czarnowski S., Ludzie zbędni w stużbie przemocy [Redundant People in the Service of Violence], in: S. Czarnowski, Dzieła [Works], vol. 2, Warsaw 1956.

Hołys B. (ed.), Człowiek w sytuacji trudnej [Man in Difficult Situation], Warsaw 1991. 
Czykwin E., Stygmat społeczny [Social Stigma], Warsaw 2007.

Czyński M., Architektura w przestrzeni ludzkich zachowań [Architecture in Space of Human Behavior], Szczecin 2006.

Czyżewski M., Analiza jakościowa [Qualitative Analysis], in: Encyklopedia socjologii [Encyclopedia of Sociology], ed. W. Kwaśniewicz, Warsaw 1998.

Czyżewski M., Etnometodologia [Ethnomethodology], in: Encyklopedia socjologii [Encyclopedia of Sociology], ed. W. Kwaśniewicz, Warsaw 1998.

Datner S., Las sprawiedliwych. Karta z dziejów ratownictwa Żydów w okupowanej Polsce [A Forest of the Righteous. Page from History of Saving Jews in Occupied Poland], Warsaw 1968.

Davies N., Powstanie 1944 [Rising 1944], Cracow 2005.

Delumeau J., Sin and Fear: The Emergence of the Western Guilt Culture, $13^{\text {th }}-18^{\text {th }}$ Centuries, New York 1991.

Denzin N., Interpretive Biography, London 1989.

Denzin N., Interpretive Interactionism, London 1989.

Ambrosewicz J., Hońdo L. (eds.), Dlaczego należy uczyć o Holokauście [Why Should We Teach about the Holocaust], Cracow 2005.

Domańska E., Mikrohistorie. Spotkania w międzyświatach [Microhistories. InterWorlds' Encounters], Poznań 1999.

Bartoszewski W. (ed.), Doświadczenia lat wojny 1939-1945. Fakty. Postawy. Refleksje [Experiences of Years of War 1939-1945. Facts. Attitudes. Thoughts], Cracow 1980.

Dymkowski M., Wprowadzenie do psychologii historycznej [Introduction to Historical Psychology], Gdańsk 2003.

Eco U., La struktura assente. Introduzione alla ricerca semiologia, Milano 1968.

Eco U., Pejzaż semiologiczny [A Semiotic Landscape], Warsaw 1972.

Edensor T., Tożsamość narodowa, kultura popularna i życie codzienne [National Identity, Popculture and Everyday Life], Cracow 2004.

Eliade M., The Sacred and The Profane. The Nature of Religion, trans. W.R. Trask, New York 1957.

Eliade M., A History of Religious Ideas, Chicago 1981.

Eliasz A., Psychologia ekologiczna [Ecological Psychology], Warsaw 1993.

Engelking B., Zagłada i pamięć. Doświadczenie Holocaustu i jego konsekwencji opisane na podstawie relacji autobiograficznych [Holocaust and Memory. The Experience of the Holocaust and Its Consequences: An Investigation Based on Personal Narratives], Warsaw 1994. 
Engelking B., “Czas przestał dla mnie istnieć...” Analiza doświadczenia czasu w sytuacji ostatecznej ["Time Stopped for Me..." an Analysis of Time in the Ultimate Situation], Warsaw 1996.

Engelking B., "Szanowny panie gistapo". Donosy do władz niemieckich $w$ Warszawie i okolicach w latach 1940-1941 ["Dear Mister Gistapo". Denunciations to German Authorities in Warsaw and Surrounding Areas in 1940-1941], Warsaw 2003.

Engelking B., "Dolary skupuje, koty przechowuje" [I Buy Dollars and Keep Cats] (Barbara Engelking interwieved by Anna Bikont), "Gazeta Wyborcza Świąteczna" 2008, No. 40.

Engelking B., Jest taki piękny słoneczny dzień... Losy Żydów szukających ratunku na wsi polskiej 1942-1945 [Such a Beautiful Sunny Day... Jews Seeking Refuge in the Polish Countryside, 1942-1945], Warsaw 2011.

Engelking B., Leociak J., Getto warszawskie. Przewodnik po nieistniejacym mieście [The Warsaw Ghetto. A Guide to a Non-Existent City], Warsaw 2001.

Engelking B., Libionka D., Żydzi w powstańczej Warszawie [Jews in the Warsaw Uprising], Warsaw 2009.

Engelking B., Tych F., Żbikowski A., Żyndul J., Pamięć. Historia Żydów polskich przed, w czasie i po Zagładzie [Memory. History of Polish Jews before, during and after the Shoah], Warsaw 2004.

Filipkowski P., Historia mówiona a wojna [Oral History and War], in: Wojna. Doświadczenie i zapis. Nowe źródła, problemy, metody badawcze [War. Experience and Records. New Sources, Issues, Research Methods], eds. S. Buryła, P. Rodak, Cracow 2006.

Foucault M., Nadzorować i karać [Discipline and Punish], Warsaw 1998.

Frančič M., Ludzie luźni w osiemnastowiecznym Krakowie [Loose People in $18^{\text {th }}$ Century Cracow], Wrocław 1967.

Friedmann S., A History of the Holocaust, London 2004.

Frieske K.W., Marginalność społeczna [Social Marginality], in: Encyklopedia socjologii [Encyclopedia of Sociology], vol. 2, ed. W. Kwaśniewicz, Warsaw 1999.

Frisch M., A Shared Authority: Essays on the Craft and Meaning of Oral and Public History, Albany 1990.

Fuks M., Z dziejów Wielkiej Katastrofy narodu żydowskiego [The History of the Great Catastrophe of the Jewish People], Poznan 1999.

Gądecki J., Architektura i tożsamość. Rzecz o antropologii architektury [Architecture and Identity. On Anthropology of Architecture], Warsaw 2005.

Gajewski P., Zapisy myśli o przestrzeni [Thoughts on Space], Cracow 2001. 
Gennep van A., Rites of Passage, M.B. Vizedom, G.L. Caffee, London-Henley 1977.

Geremek B., Ludzie marginesu w późnośredniowiecznym Paryżu. XIV-XV wiek [Marginalized People in Late Medieval Paris. $14^{\text {th }}-15^{\text {th }}$ Centuries], Poznan 2003.

Gibson J.J., The Ecological Approach to Visual Perception, Boston 1979.

Giddens A., Nowoczesność i tożsamość [Modernity and Self Identity], Warsaw 2001.

Giedion S., Przestrzeń, czas, architektura [Space, Time and Architecture], Warsaw 1968.

Gilbert M., Holocaust, Warsaw 2002.

Ginzburg C., Ser i robaki. Wizja świata pewnego młynarza w XVI wieku [Cheese and Maggots. Vision of the World of a Miller in $16^{\text {th }}$ Century], Warsaw 1989.

Giza A., Autobiografia: między symbolem a rzeczywistościa [Autobiography: Between Symbol and Reality], in: Poza granicami socjologii ankietowej [Outside Survey Sociology], eds. A. Sułek, K. Nowak, A. Wyka, Warsaw 1989.

Glaser B.G., Strauss A.L., The Discovery of Grounded Theory: Strategies for Qualitative Research, Chicago 1967.

Gliszczyńska X., Człowiek jako podmiot życia społecznego [Human as a Subject of Social Life], Wrocław 1983.

Goffman E., Presentation of Self in Everyday Life, New York 1956.

Goffman E., Asylums, New York 1961.

Goffman E., Stigma. Notes on the Management of Spoiled Identity, New York 1963.

Gordon K., O dziwnych uczuciach [On Strange Feelings], Cracow 2005.

Grabowski J., Ja tego Żyda znam! Szantażowanie Żydów w Warszawie 1939-1943 [I Know that Jew! Blackmailing Jews in Warsaw 1939-1943], Warsaw 2004.

Grabowski J., Judenjagd. Polowanie na Żydów 1942-1945. Studium dziejów pewnego powiatu [Hunt for the Jews: Betrayal and Murder in German-Occupied Poland], Warsaw 2011.

Greenspan H., On Listening to Holocaust Survivors. Recounting and Life History, Westport 1998.

Gregier M., "Zniewolone dzieciństwo". Sytuacja dzieci żydowskich w getcie warszawskim i po aryjskiej stronie ["Enslaved Childhood". Situation of Jewish Children in the Warsaw Ghetto and on the Aryan Side], master's thesis, Warsaw 2004.

Gregory R.L., Colman A. M. (eds.), Sensation and Perception, London-New York 1995.

Gross J.T., Sąsiedzi [Neighbors], Sejny 2000. 
Gross J.T., Upiorna dekada [Ghastly Decade], Cracow 2001.

Gross J.T., Wokót "Sąsiadów". Polemiki i wyjaśnienia [On "Neighbors". Plemics and Explanations], Sejny 2003.

Gross J.T., Fear. Antisemitism in Poland after Auschwitz. An Essay in Historical Interpretation, New York 2006.

Gross J.T., Strach. Antysemityzm w Polsce tuż po wojnie. Historia moralnej zapaści [Fear. Anti-Semitism in Poland after Auschwitz], Cracow 2008.

Gross J.T., Grudzińska-Gross I., Złote żniwa [Golden Harvest], Cracow 2011.

Gryglewski R.W., Mumifikacja ciała ludzkiego w świetle historii obyczajów i nauk medycznych [Mummification of Human Body in History of Customs and Medical Sciences], Cracow 2005.

Grynberg M., Żydzi w rejencji ciechanowskiej 1939-1942 [Jews in Regierungsbezirk Zichenau 1939-1942], Warsaw 1984.

Grynberg M., Bunkry i schrony w warszawskim getcie [Bunkers and Shelters in the Warsaw Ghetto], "Biuletyn ŻIH” 1989, No. 149.

Gutman I., Żydzi warszawscy 1939-1945. Getto - podziemie - walka [Warsaw Jews 1939-1945. Ghetto - Underground - Fight], Warsaw 1993.

Halbwachs M., Społeczne ramy pamięci [Social Frameworks of Memory], Warsaw 1969.

Hall E.T., The Silent Language, New York 1959.

Hall E.T., The Hidden Dimension, New York 1990.

Hall M.R., Hall E.T., The Fourth Dimension in Architecture, New York 2016.

Hanson J.K.M., Nadludzkiej poddani próbie. Ludność cywilna Warszawy w powstaniu $1944 r$ [Put to Inhuman Test. Warsaw's Civilians in 1944 Uprising], Warsaw 2004.

Hass A., In the Shadow of the Holocaust: The Second Generation, New York 1996.

Haumann H., Historia Żydów w Europie Środkowej i Wschodniej [History of East European Jews], Warsaw 2000.

Heidegger M., "Introduction to What is Metaphysics?", trans. W. Kaufmann, in: Pathmarks, ed. M. Heidegger, Cambridge 1998.

Helling I.K., Metoda badań biograficznych [Biographical Research Method], in: Metoda biograficzna w socjologii [Biographical Method in Sociology], eds. J. Włodarek, M. Ziółkowski, Warsaw-Poznań 1990.

Hertz A., Żydzi w kulturze polskiej [Jews in Polish Culture], Warsaw 2003.

Herzfeld M., Antropologia. Praktykowanie teorii w kulturze i społeczeństwie [Anthropology: Theoretical Practice in Culture and Society], Cracow 2004.

Hilberg R., The Destruction of European Jews, Chicago 1961. 
Hilberg R., Perpetrators, Victims, Bystanders, London 1993.

Historia i kultura Żydów Janowca nad Wisła, Kazimierza Dolnego i Puław. Fenomen kulturowy miasteczka - sztetl. Materiały z sesji naukowej "V Janowieckie Spotkania Historyczne" Janowiec nad Wisła 28 czerwca 2003 roku [History and Culture of Jews from Janowiec in the Lublin Voivodeship, Kazimierz Dolny and Pulawy. The Cultural Phenomenon of Town - Shtetl. Materials from "5 th Janowiec Historical Meetings" Scientific Session, Janowiec in the Lublin Voivodeship, 28 $8^{\text {th }}$ June 2003], Janowiec in the Lublin Voivodeship 2003.

Cała A., Węgrzynek H., Zalewska G. (eds.), Historia i kultura Żydów polskich. Stownik [History and Culture of Polish Jews. Dictionary], Warsaw 2000.

Schulze W. (ed.), Historia społeczna, historia codzienności, mikrohistoria [Social History, Everyday Life History, Microhistory], Warsaw 1996.

Ariès P., Duby G., Perrot M., Prost A., Veyne P. Vincent G. (eds.), A History of Private Life, vols. 1-5, Cambridge 1987.

Hoffman E., Sztetl [Shtetl], Warsaw 2001.

Grinberg D., Szapiro P. (eds.), Holocaust z perspektywy pótwiecza. Pięćdziesiata rocznica powstania $w$ getcie warszawskim [Holocaust from the Perspective of Half a Century. 50 $0^{\text {th }}$ Anniversary of the Warsaw Ghetto Uprising], Warsaw 1993.

Hońdo L., Przestrzeń żydowskiego cmentarza [Space of a Jewish Cemetery], in: Śmierć, przestrzeń, czas, tożsamość [Death, Space, Time, Identity], eds. K. Grodziska, J. Purchla, Cracow 2002.

Jędrzejczak D. (ed.), Humanistyczne oblicze miasta [Humanistic Face of the City], Warsaw 2003.

Iranek-Osmecki K., Kto ratuje jedno życie... Polacy i Żydzi 1939-1945 [Who Saves One Life... Poles and Jews 1939-1945], London 1968.

Jałowiecki B., Miasto jako podmiot badań semiologii [City as a Subject of Semiological Studies], "Górnośląskie Studia Socjologiczne” 1982, No. 15.

Jałowiecki B., Społeczne wytwarzanie przestrzeni [Social Construction of Space], Warsaw 1988.

Jałowiecki B., Szczepański M., Miasto i przestrzeń w perspektywie socjologicznej [City and Space in Sociological Perspective], Warsaw 2001.

Janion M., Żyjąc tracimy życie. Niepokojące tematy egzystencji [We Lose Life by Living. Disturbing Topics of Existence], Warsaw 2003.

Janowska K., Mucharski P., Rozmowy na koniec wieku 3 [Conversations at the End of the Century 3], Cracow 1999.

Janowska K., Mucharski P., Rozmowy na nowy wiek 1 [Conversations for the New Century 1], Cracow 2001.

Jaspers K., Philosophy of Existence, trans. R.F. Grabay, Philadelphia 1971. 
Jones E., Żydzi Lwowa w okresie okupacji 1939-1945 [Lviv Jews during the Occupation 1939-1945], Łódź 1999.

Kaczmarek J., Podejście geobiograficzne w geografii społecznej. Zarys teorii i podstawy metodyczne [Geobiographical Approach in Social Geography. Outline of the Theory and Basic Methodology], Łódź 2005.

Kamiński M.M., Subkultura aresztów śledczych [Subculture of Holding Facilities], "Studia Socjologiczne" 1993, No. 3-4.

Karpińska G.E., Miejsce wyodrębnione ze świata. Przykład łódzkich kamienic czynszowych [Space Isolated from the World. Example of Tenement Townhouses in Łódź], Łódź 2000 [Łódzkie Studia Etnograficzne, No. 38].

Kasjanowicz K., Dom w getcie warszawskim [Home in the Warsaw Ghetto], master's thesis, Warsaw 2006.

Kaźmierska K., Doświadczenie wojenne Polaków a kształtowanie tożsamości etnicznej. Analiza narracji kresowych [Wartime Experience of Poles and Shaping of the Ethnic Identity. Analysis of Borderland Narrations], Warsaw 1999.

Kaźmierska K., Holocaust w narracjach biograficznych ofiar, sprawców zbrodni oraz ich rodzin [Holocaust in Biographical Narratives of Victims, Perpetrators and Their Families], "Kultura i Społeczeństwo" 1999, No. 1.

Kersten K., Relacje jako typ źródła historycznego [Testimonies as a Type of Historical Source], "Kultura i Społeczeństwo" 1970, No. 14(3).

Kersten K., Ludzie na drogach. O przesiedleniach ludności w Polsce 1939-1948 [People on Roads. On Displacements in Poland 1939-1945], "Res Publica" 1987, No. 4.

Kersten K., Pisma rozproszone [Dispersed Works], Torun 2005.

King P., Private Dwelling. Contemplating the Use of Housing, London-New York 2004.

Kłoskowska A., Wojna i socjologia [War and Sociology], "Kultura i Społeczeństwo" 1989, No. 33(2).

Kocjan K., Zagłada olkuskich Żydów [Holocaust of Jews in Olkusz], Olkusz 2002.

Kofta M., Kontrola psychologiczna nad otoczeniem. Ramy pojęciowe teorii [Psychological Control over the Surroundings. Conceptual Framework of the Theo$r y$ ], "Psychologia Wychowawcza" 1977, No. 2.

Kogan I., The Cry of Mute Children: A Psychoanalytic Perspective of the Second Generation of the Holocaust, London 1995.

Kołakowski L., Czy diabeł może być zbawiony i 27 innych kazań [Can the Devil be Saved and 27 Other Sermons], London 1984. 
Kolbuszewski J., Semiotyczny pejzaż cmentarza [Semiotic Landscape of a Cemetery], in: Cmentarze żydowskie [Jewish Cemeteries], vol. 2, ed. J. Woronczak, Wrocław 1995.

Kolbuszewski J., Cmentarze [Cemeteries], Wrocław 1996.

Kołodziejczyk M., 316 ptaszków. Nazwano ich cichociemnymi [316 Birds. They Called Them Cichociemni], "Pomocnik Historyczny" No. 1, complimentary supplement to "Polityka" weekly 2006, No. 7(2542).

Konecki K., Studia z metodologii badań jakościowych. Teoria ugruntowana [Studies on Methodology of Qualitative Research. Grounded Theory], Warsaw 2000.

Konior L., Homo architectonicus. Szkice - krytyka - wspomnienia [Homo Architectonicus. Drafts - Critique - Memoirs], Cracow 2004.

Kopówka E., Żydzi siedleccy [Siedlce Jews], Siedlce 2001.

Kotula F., Losy Żydów rzeszowskich 1939-1944 [History of Jews from Rzeszów 1939-1944], Rzeszów 1999.

Kowalak T., Marginalizacja i marginalność społeczna [Social Marginalization and Marginality], Warsaw 1998.

Kowalski S., To oczywiste [It's Obvious], in: Dlaczego należy uczyć o Holokauście [Why Should We Teach about the Holocaust], eds. J. Ambrosewicz-Jacob, L. Hońdo, Cracow 2005.

Krakowski S., Żydowski opór w Generalnym Gubernatorstwie [Resistance of Jews in General Government], in: Akcja Reinhardt. Zagłada Żydów w Generalnym Gubernatorstwie [Reinhardt Action. Holocaust of Jews in General Government], ed. D. Libionka, Warsaw 2004.

Krasnodębski Z., Rozumienie ludzkiego zachowania [Understanding Human Behavior], Warsaw 1986.

Kurek E., Dzieci żydowskie w klasztorach. Udział żeńskich zgromadzeń zakon$n y c h w$ akcji ratowania dzieci żydowskich $w$ Polsce w latach 1939-1945 [Jewish Children in Monasteries. Participation of Female Assemblies in Saving Jewish Children in Poland in 1939-1945], Lublin 2001.

Kuwałek R., Obóz zagłady w Bełżcu [Bełżec Death Camp], Lublin-Bełżec 2005.

Kwaśniewski J., Koncepcje podkultur dewiacyjnych [Concept of Deviation Subcultures], in: Zagadnienia patologii społecznej [Problems of Social Pathology], ed. A. Podgórecki, Warsaw 1976.

La Capra D., Writing History, Writing Trauma, Baltimore 2001.

Langer L., Holocaust Testimonies: The Ruins of Memory, New Haven 1991.

Lanzmann C., Shoah, Koszalin 1993.

Le Bon G., Psychology of Crowds, London 1896. 
Le Roy Ladurie E., Montaillou - wioska heretyków [Montaillou - A Village of Heretics], Warsaw 1988.

Lejeune P., Pakt autobiograficzny [Autobiographical Pact], “Teksty” 1975, No. 5.

Lenartowicz J.K., Słownik psychologii architektury [Dictionary of Psychology of Architecture], Cracow 2005.

Leociak J., Tekst wobec Zagłady [Text Regarding the Shoah], Wrocław 1997.

Leociak J., Literatura dokumentu osobistego jako źródło do badań nad zagłada Żydów. Rekonesans metodologiczny [Literature of Personal Document as a Source of Studies of the Shoah. Methodological Reconnaissance], "Zagłada Żydów" 2005, No. 1.

Leociak J., Bombardowania miast jako doświadczenie graniczne [City Bombings as a Border Experience], in: Wojna. Doświadczenie i zapis. Nowe źródła, problemy, metody badawcze [War. Experience and Records. New Sources, Issues, Research Methods], eds. S. Buryła, P. Rodak, Cracow 2006.

Leociak J., Wizerunek Polaków w zapisach Żydów z dystryktu warszawskiego [Image of Poles in Notes of Jews from Warsaw District], in: Prowincja noc. Życie $i$ zagłada Żydów $w$ dystrykcie warszawskim [Province of the Night. Life and Holocaust of the Jews in Warsaw District], eds. B. Engelking, J. Leociak, D. Libionka, Warsaw 2007.

Leociak J., Ratowanie. Opowieści Polaków i Żydów [Saving. Stories of Poles and Jews], Cracow 2010.

Leoński J., Ekologia społeczna Floriana Znanieckiego [Social Ecology of Florian Znaniecki], "Diametros. Internetowe Czasopismo Filozoficzne przy Instytucie Filozofii Uniwersytetu Jagiellońskiego", www.diametros.iphils.uj.edu.pl. [01.2012].

Levi P., Czy to jest człowiek? [Is This a man?], Warsaw 1996.

Levine M.G., Bezdomność w literaturze wojennej: typologia obrazowania [Homelessness in Wartime Literature: Typology of Imaging], "Teksty Drugie" 1999, No. 4.

Lewandowska S., Życie codzienne Wilna w latach II wojny światowej [Everyday Life of Vilnius during World War II], Warsaw 2001.

Lewis O., Sanchez i jego dzieci. Autobiografia rodziny meksykańskiej [The Children of Sanchez: Autobiography of a Mexican Family], Warsaw 1964.

Libionka D., Polska ludność chrześcijańska wobec eksterminacji Żydów - dystrykt lubelski [Polish Christians in Relation to Extermination of the Jews - Lublin District], in: Akcja Reinhardt. Zagłada Żydów w Generalnym Gubernatorstwie [Reinhardt Action. Holocaust of Jews in General Government], ed. D. Libionka, Warsaw 2004. 
Lisowski A., Koncepcje przestrzeni w geografii człowieka [Concepts of Space in Human Geography], Warsaw 2003.

Łukasiewicz P., Funkcje domu w okresie okupacji niemieckiej [Functions of Home during German Occupation], "Kultura i Społeczeństwo" 1989, No. 33(2).

Lynch K., The Image of the City, Cambridge 1960.

Madajczyk C., Polityka III Rzeszy w okupowanej Polsce [Policy of Third Reich in Occupied Poland], Warsaw 1970.

Madurowicz M., Sfera sacrum w przestrzeni miejskiej Warszawy [Sacrum in Urban Space of Warsaw], Warsaw 2002.

Maffesoli M., La Conquête du présent. Pour une sociologie de la vie quotidienne, Paris 1979.

Majewski J.S., Warszawa nieodbudowana [Non-Rebuilt Warsaw], Warsaw 1998.

Mała encyklopedia wojskowa [Pocket Military Encyclopedia], Warsaw 1971.

Małe miasta. Przestrzenie [Small Towns. Spaces], ed. M. Zemło, Supraśl 2003.

Maranda M., Nazistowskie obozy zagłady. Opis i próba analizy zjawiska [Nazi Death Camps. Description and Analysis Attempt of the Phenomenon], Warsaw 2002.

Markowski A., Rodzina, struktura własności i typy gospodarstw domowych w sztetł przełomu XIX i XX wieku. Przykład Wasilkowa [Family, Ownership Structure and Types of Households in Shtetl in 19th $/ 20^{\text {th }}$ Century. Example of Wasilków], in: Sztett - wspólne dziedzictwo. Szkice z dziejów ludności żydowskiej Europy Srodkowo-Wschodniej [Shtetl - Common Heritage. Drafts of History of Jewish People of Central and Eastern Europe], eds. A. Markowski, B. Śleszyński, Białystok 2003.

Marszałek J., Majdanek, obóz koncentracyjny w Lublinie [Majdanek, Concentration Camp in Lublin], Warsaw 1987.

Marszałek J., Obozy pracy w Generalnym Gubernatorstwie w latach 1939-1945 [Labor Camps in General Government in 1939-1945], Lublin 1998.

Maslow A.H., Motivation and Personality, New York 1954.

Matywiecki P., Kamień graniczny [Border Stone], Warsaw 1994.

Melchior M., Zagłada a tożsamość [The Holocaust and Identity], Warsaw 2004.

Melchior M., Zagłada i stosunki polsko-żydowskie w opracowaniach socjologicznych [Holocaust and Polish-Jewish Relations in Sociological Studies], "Zagłada Żydów" 2005, No. 1.

Melchior M., Uciekinierzy z gett po "stronie aryjskiej" na prowincji dystryktu warszawskiego - sposoby przetrwania [Escapees from Ghettos in the Province of the Warsaw District - Methods of Survival], in: Prowincja noc. Życie i zagłada Żydów w dystrykcie warszawskim [Province of the Night. Life and Holocaust 
of the Jews in Warsaw District], eds. B. Engelking, J. Leociak, D. Libionka, Warsaw 2007.

Miłosz C., Wyprawa w dwudziestolecie [Journey into Two Decades], Cracow 1999.

Miłosz C., Zaczynając od moich ulic [Starting with My Streets], Cracow 2006.

Moczydłowski P., Drugie życie w instytucji totalnej [Second Life in a Total Institution], Warsaw 1988.

Moczydłowski P., O sposobach wgladu w sekrety stosunków międzyludzkich. Przypadek instytucji totalnych [On the Ways of Looking into Secrets of Interpersonal Relations. Case of Total Institutions], "Kultura i Społeczeństwo" 1990, No. 1.

Mokrzycki E., Założenia socjologii humanistycznej [Assumptions of Humanistic Sociology], Warsaw 1971.

Nalewajko-Kulikov J., Strategie przetrwania. Żydzi po aryjskiej stronie Warszawy [Strategies of Survival. Jews on the Aryan Side of Warsaw], Warsaw 2004.

Nowicka E., Świat człowieka, świat kultury [World of Man, World of Culture], Warsaw 1998.

Ogryzko-Wiewiórkowski H., Od proksemiki do socjometrii [From Proxemics to Sociometry], in: Przestrzeń we współczesnej nauce [Space in Modern Science], eds. W.A. Kamiński, G. Nowak, S. Symotiuk, Zamość 2003.

Chmielowiec P. (ed.), Okupacja sowiecka ziem polskich 1939-1941 [Soviet Occupation on Polish Land 1939-1941], Rzeszów-Warsaw 2005.

Olejnik L., Polityka narodowościowa Polski w latach 1944-1960 [National Policy in Poland in 1944-1960], Łódź 2003.

Dunaway K.D., Willa K.B. (eds.),Oral History. An Interdisciplinary Anthology, Walnut Creek 1996.

Perks R., Thompson A., (eds.), The Oral History Reader, London-New York 1998.

Pakalski Z., Nalewki. Z dziejów polskiej i żydowskiej ulicy w Warszawie [Nalewski Street. History of Polish and Jewish Street in Warsaw], Warsaw 2003.

Pakuła Z., Siwe kamienie. Wielkopolscy Żydzi [Gray Stones. Jews from Greater Poland], Poznań 1998.

Palska H., Badacz społeczny wobec tekstu. Niektóre problemy analizy jakościowej $w$ socjologii i teorii literatury [Social Researcher Regarding the Text. Some Problems of Qualitative Analysis in Sociology and Theory of Literature], in: Spojrzenie na metodę. Studia $z$ metodologii badań socjologicznych [Looking at the Method. Studies on Methodology of Social Research], eds. K. Lutyńska, H. Domański, Warsaw 1999.

Palska H., "Mnie się pogmatwało w tym pijanym moim życiu, pozagubiało..." [It All Got Confused and Misplaced in That Drunken Life of Mine... ], a "shortened" 
biography of a homeless alcoholic (case of Z. family, No. 25), in: Zrozumieć biednego [To Understand the Poor], ed. E. Tarkowska, Warsaw 2000.

Palska H., Bieda $i$ dostatek. O nowych stylach życia $w$ Polsce końca lat dziewięćdziesiątych [Poverty and Health. On New Styles of Living in Poland in the Late 90s], Warsaw 2002.

Pamięć, miejsce, obecność. Ścieżkami pamięci [Memory, Place, Presence. Paths of Memory], "Scriptores" 2003, No. 2.

Patoczka P., "Ściany" i "bramy" w krajobrazie ["Walls" and "Gates" in a Landscape], Cracow 2000.

Paulsson G.S., Secret City. The Hidden Jews of Warsaw 1940-1945, New HeavenLondon 2002.

Paulsson G.S., Stosunki polsko-żydowskie w okupowanej Warszawie (1940-1945) [Polish-Jewish Relations in Occupied Warsaw (1940-1945)], in: Akcja Reinhardt. Zagłada Żydów w Generalnym Gubernatorstwie [Reinhardt Action. Holocaust of Jews in General Government], ed. D. Libionka, Warsaw 2004.

Paulsson G.S., Utajone miasto. Żydzi po aryjskiej stronie Warszawy (1940-1945) [Secret City. The Hidden Jews of Warsaw 1940-1945], Cracow 2007.

Pawełczyńska A., Wartości a przemoc. Zarys socjologicznej problematyki Oświęcimia [Values and Violence. Overview of Sociological Issues of Auschwitz], Warsaw 2004.

Paziński P., Kidusz Haszem i Kidusz Hachaim [Kiddush Ha-shem and Kiddush Ha-hayyim], "Midrasz" 2003, No. 72.

Polski słownik judaistyczny. Dzieje, kultura, religia, ludzie [Polish Judaism Dictionary. History, Culture, Religion, People], prepared by Z. Borzymińska, R. Żebrowski, Warsaw 2003.

Poławski P., Obrazy bezdomnych i bezdomności. Instytucjonalizacja reakcji na problem spoteczny [Images of the Homeless and Homelessness. Institutionalization of Reaction to Social Issue], in: Polityka społeczna. Wybrane problemy. Wybór artykułów z lat 1999-2005 [Social Policy. Selected Issues. Selected Articles from 1999-2005], Warsaw 2005.

Portelli A., Death of Luigi Trastulli and Other Stories: Form and Meaning in Oral History, Albany 1991.

Porteous J.D., Domicide: The Destruction of Home, in: The Home: Words, Interpretations, Meanings and Environments, ed. D.N. Benjamin, London 1996.

Potocki A., Bieszczadzkie losy [Fates in Bieszczady], Rzeszów-Krosno 2000.

Potocki A., Żydzi rymanowscy [Rymanów Jews], Krosno 2000.

Sułek A., Nowak K., Wyka A. (eds.), Poza granicami socjologii ankietowej [Outside Survey Sociology], Warsaw 1989. 
Prekerowa T., Konspiracyjna Rada Pomocy Żydom w Warszawie 1942-1945 [Conspiracy Council to Aid Jews in Warsaw 1942-1945], Warsaw 1982.

Prekerowa T., Zarys dziejów Żydów w Polsce w latach 1939-1945 [Outline of History of Jews in Poland in 1939-1945], Warsaw 1992.

Przestrzeń i społeczeństwo. Z badań ekologii społecznej [Space and Society. Studies of Social Ecology], ed. Z. Pióro, Warsaw 1982.

Przestrzeń we wspótczesnej nauce [Space in Contemporary Science], eds. W.A. Kamiński, G. Nowak, S. Symotiuk, Zamość 2003.

Psychologia. Podręcznik akademicki [Psychology. Textbook], ed. J. Strelau, Gdańsk 2002.

Rasmussen S.E., Odczuwanie architektury [Experiencing Architecture], Warsaw 1999.

Rejestry miejsc i faktów zbrodni popelnionych przez okupanta hitlerowskiego na ziemiach polskich w latach 1939-1945 [Registry of Places and Crimes of Nazi Occupants on Polish Lands in 1939-1945], Main Commission for the Investigation of Nazi Crimes in Poland 1980-1994.

Riemann G., Schütze F., Trajektoria jako podstawowa koncepcja teoretyczna w analizach cierpienia $i$ bezładnych procesów społecznych [Trajectory as a Basic Theoretical Concept in Analyzing Suffering and Disorderly Social Processes], "Kultura i Społeczeństwo" 1992, No. 2.

Ringelblum E., Stosunki polsko-żydowskie w czasie drugiej wojny światowej. Uwagi i spostrzeżenia [Polish-Jewish Relations during the Second World War. Notes and Observations], Warsaw 1988.

Rokuszewska-Pawełek A., Chaos i przymus. Trajektorie wojenne Polaków - analiza biograficzna [Chaos and Compulsion. Wartime Trajectories of Poles - Biographical Analysis], Łódź 2002.

Rosenbaum I.J., The Holocaust and Halakhah, New York 1976.

Rotter J., Generalized Expectancies for Internal vs External Control of Reinforcement, "Psychological Monographies" 1966, No. 80 (1).

Rybczyński W., Dom. Krótka historia idei [Home. Short Story of an Idea], Gdańsk-Warsaw 1996.

Rybczyński W., Najpiękniejszy dom na świecie [The Most Beautiful House in the World], Cracow 2003.

Schütze F., Trajektoria cierpienia jako przedmiot badań socjologii interpretatywnej [Trajectory of Suffering as a Study Subject of Interpretative Sociology], "Studia Socjologiczne" 1997, No. 1.

Berger A.L., Berger N. (eds.), Second Generation Voices: Reflections by Children of Holocaust Survivors and Perpetrators, Syracuse 2001. 
Sennett R., Flesh and Stone: The Body and the City in Western Civilization, New York-London 1996.

Sereny G., Into That Darkness, London 1974.

Simmel G., "Bridge and Door", trans. M. Ritter, in: Theory, Culture and Society, 1994.

Skibińska A., Powroty ocalałych [Return of the Survivors], in: Prowincja noc. Życie i zagłada Żydów w dystrykcie warszawskim [Province of the Night. Life and Holocaust of the Jews in Warsaw District], ed. B. Engelking, J. Leociak, D. Libionka, Warsaw 2007.

Skibińska A., Źrodła do badań nad zagłada Żydów na okupowanych ziemiach polskich. Przewodnik archiwalno-bibliograficzny [Sources for Research on the Shoah on Occupied Polish Land. Archive-Bibliographical guide], Warsaw 2007.

Skibińska A., Petelewicz J., Udział Polaków w zbrodniach na Żydach na prowincji regionu świętokrzyskiego [Participation of Poles in Crimes against Jews in Countryside of Świętokrzyski District], "Zagłada Żydów” 2005, No. 1.

Sommer R., Personal Space: The Behavioral Basis of Design, Englewood Cliffs, New Jersey 1969.

Spector S., The Holocaust of Volhynian Jews 1941-1944, Jerusalem 1990.

Spiss A., Wiejskie cmentarze w Polsce [Jewish Village Cemeteries], in: Śmierć, przestrzeń, czas, tożsamość [Death, Space, Time, Identity], eds. K. Grodziska, J. Purchla, Cracow 2002.

Dunin-Wąsowicz K. (ed.), Społeczeństwo polskie wobec martyrologii $i$ walki Żydów w latach II wojny światowej. Materiały z sesji w Instytucie Historii PAN $w$ dniu 11 III 1993 r [Polish Society in Relation to Martyrdom of the Jews during WWII. Materials from a Session in Institute of History PAN on $11^{\text {th }}$ March 1993], Warsaw 1996.

Steinlauf M.C., Pamięć nieprzyswojona [Bondage of the Dead], Warsaw 2001.

Stokols D., The Experience of Crowding in Primary and Secondary Environments, "Environment and Behavior" 1976, No. 8(1).

Stola D., Nadzieja i zagłada. Ignacy Schwarzbart - żydowski przedstawiciel w Radzie Narodowej RP (1940-1945) [Hope and Holocaust. Ignacy Schwarzbart - Jewish Representative on the Polish National Council (1940-1945)], Warsaw 1995.

Struk J., Holokaust $w$ fotografiach. Interpretacje dowodów [Holocaust in Photographs. Interpretations of Proof], Warsaw 2007.

Sulima R., Antropologia codzienności [Anthropology of Commonplace], Cracow 2000.

Summerfield P., Reconstructing Women's Wartime Lives: Discourse and Subjectivity in Oral Histories of the Second World War, Manchester 1998. 
Szacka B., Pamięć zbiorowa i wojna [Collective Memory and War], "Przegląd Socjologiczny" 2000, No. 2.

Szacka B., Wprowadzenie do socjologii [Introduction to Sociology], Warsaw 2003.

Szacki J., Znaniecki [Znaniecki], Warsaw 1986.

Szacki J., Historia myśli socjologicznej [History of Sociological Thought], Warsaw 2002.

Szarfenberg R., Marginalizacja i wykluczenie społeczne w historii [Marginalisation and Social Exclusion in History], 2004, www.ips.uw.edu.pl/rszarf/wykluczenie. [01.2012].

Szarfenberg R., Marginalizacja i wykluczenie społeczne. Wykłady [Marginalisation and Social Exclusion in History. Lectures], 2006, www.ips.uw.edu.pl/ rszarf/wykluczenie. [01.2012].

Szarota T., Okupowanej Warszawy dzień powszedni. Studium historyczne [Everyday Life in Occupied Poland. Historical Study], Warsaw 1988.

Szarota T., Życie codzienne w stolicach okupowanej Europy. Szkice historyczne. Kronika wydarzeń [Everyday Life in Capitals of Occupied Europe. Historical Drafts. Chronicle], Warsaw 1995.

Szczepański J., Socjologia. Rozwój problematyki i metod [Sociology. Development of Problems and Methods], Warsaw 1969.

Szczepański J., Elementarne pojęcia socjologii [Elementary Sociology], Warsaw 1970.

Szczepański J., Sprawy ludzkie [Human Matters], Warsaw 1988.

Szmidt B., Ład przestrzeni [Order of Space], Warsaw 1981.

Markowski A., Śleszyński B. (eds.), Sztetł - wspólne dziedzictwo. Szkice z dziejów ludności żydowskiej Europy Środkowo-Wschodniej [Shtetl - Common Heritage. Drafts of History of Jewish People of Central and Eastern Europe], Białystok 2003.

Sztompka P., Socjologia, Cracow 2001.

Sztompka P., Nowe formy życia społecznego a nowy kształt teorii socjologicznej [New Forms of Social Life and New Shape of Sociological Theory], 2007, http:// www.zjazdpts.uz.zgora.pl/ab_okraglystol.html. [01.2012].

Szwajca K., Kłopotliwa "świętośćc [Troublesome "Sanctity”], "Midrasz" 2007, No. 1.

Szymańska S., Ludność żydowska w Otwocku podczas drugiej wojny światowej [Jews in Otwock during WW2], Warsaw 2002. [01.2012].

Tarkowska E., Czas $w$ życiu Polaków. Wyniki badań, hipotezy, impresje [Time in Life of Poles. Findings, Hypotheses, Impressions], Warsaw 1992. 
Tarkowska E., O dawnej i obecnej biedzie $w$ Polsce [On Former and Present Poverty in Poland], in: Zrozumieć biednego [To Understand the Poor], ed. E. Tarkowska, Warsaw 2000.

Tec N., Defiance. The Bielski Partisans. The Story of the Largest Armed Rescue of Jews by Jews during World War II, New York-Oxford 1993.

Tec N., Diaries and Oral History. Reflections on Methodological Issues in Holocaust Research, in: Holocaust Chronicles: Individualizing the Holocaust through Diaries and Other Contemporaneous Personal Accounts, prepared by R.M. Shapiro, New York 1999.

Thomas L.V., Trup. Od biologii do antropologii [The Corpse. From Biology to Anthropology], Łódź 1991.

Thompson P., The Edwardians: The Remaking of British Society, London 1975.

Thompson P., The Voice of the Past, Oxford 2000.

Thoreau H.D., Walden czyli życie w lesie [Walden; Or, Life in the Woods], Warsaw 1991.

Tokarska-Bakir J., Rzeczy mgliste [Misty Things], Sejny 2004.

Tomaszewski T., Człowiek jako podmiot i człowiek jako przedmiot [Human as a Subject and Object], in: Studia z psychologii emocji, motywacji i osobowości [Studies on Psychology, Motivation and Personality], eds. J. Reykowski, O.W. Owczynnikowa, K.Z. Obuchowski, Wrocław 1977.

Tomaszewski J., Zarys dziejów Żydów w Polsce w latach 1918-1939 [Outline of History of Jews in Poland in 1918-1939], Warsaw 1990.

Toporov V.N., Przestrzeń i rzecz [Space and Thing], Cracow 2003.

Kozłowski M., Folwarczny A., Bilewicz M. (eds.), Trudne pytania w dialogu polskożydowskim [Difficult Questions in Polish-Jewish Dialogue], Warsaw 2006.

Tuan Y.F., Space and Place, Minneapolis-London 2001.

Turner J., The Structure of Sociological Theory, Homewood 1978.

Tych F., Długi cien Zagłady [Long Shadow of the Shoah], Warsaw 1999.

Urbański K., Zagłada ludności żydowskiej Kielc 1939-1945 [Shoah of the Jewish People of Kielce 1939-1945], Kielce 1994.

Urbański K., Zagłada Żydów w dystrykcie radomskim [Shoah of the Jews in Radom District], Cracow 2004.

Venturi R., Complexity and Contradiction in Architecture, New York 1966.

Vitruvius, O architekturze ksiąg dziesięć [Ten Books on Architecture], Warsaw 1956.

Wallis A., Informacja i gwar [Information and Buzz], Warsaw 1979.

Wańczowski M., Księga żałoby i śmierci A-Z [Book of Mourning and Death A-Z], Opole 1993. 
Grzelak J. Zarycki T. (eds.), Warszawiacy o sobie i swoim mieście [Citizens of Warsaw on Themselves and Their City], Warsaw 2004.

Wąsowicz A., Życia nie starczy... [Life Is Not Enough...] (A. Wąsowicz interviewed by Piotr Paziński), "Midrasz" 2007, No. 4.

Weick K.E., The Social Psychology of Organizing, Reading 1969.

Weil S., Zakorzenienie [Rootedness], in: Wybór pism [Selected Works], ed. S. Weil, vol. 1, Warsaw 1983.

Wieczorkiewicz A., Muzeum ludzkich ciał [Museum of Human Bodies], Gdańsk 2000.

Wirth L., Housing as a Field of Sociological Research, "American Sociological Review" 1947, No. 12(2).

Włodarczyk J.A., Oblicza architektury. Próby [Faces of Architecture. Attempts], Białystok 2000.

Włodarczyk J.A., Około architektury. Przemyślenia z przełomu wieków [Around Architecture. Thoughts from the Turn of the Centuries], Białystok 2003.

Włodarczyk J.A., Żyć znaczy mieszkać. Dom mieszkalny na granicy stuleci [To Live is to Dwell. Residential Building on Turn of the Centuries], Tychy 2004.

Buryła S., Rodak P. (eds.), Wojna. Doświadczenie i zapis. Nowe źródła, problemy, metody badawcze [War. Experience and Records. New Sources, Issues, Research Methods], Cracow 2006.

Wojna żydowsko-niemiecka. Polska prasa konspiracyjna 1943-1944 o powstaniu $w$ getcie Warszawy [Jewish-German War. Polish Conspiracy Press 1943-1944 on Warsaw Ghatto Uprising], prepared by P. Szapiro, London 1992.

Opoczyńska M. (ed.), Wprowadzenie do psychologii egzystencjalnej [Introduction to Existential Psychology], Cracow 2004.

Wyka K., Życie na niby [Make-Believe Life], Cracow-Wrocław 1984.

Zabielska J.M., Ubóstwo a procesy marginalizacji społecznej [Poverty and Processes of Social Marginalization], Lublin 2007.

Zadrożyńska A., Homo faber i homo ludens: etnologiczny szkic o pracy w kulturach tradycyjnej i współczesnej [Homo Faber, Homo Ludens. Ethnological Study on Work in Traditional and Contemporary Cultures], Warsaw 1983.

Zagłada Żydów na Rzeszowszczyźnie. Album pamięci [Shoah of the Jews in Rzeszów Region. Memory Album], prepared by E. Rączy, I. Witowicz, Rzeszów-Warsaw 2004.

Żbikowski A., Żydzi krakowscy i ich gmina w latach 1869-1919 [Jews of Cracow and Their Qahal in 1869-1919], Warsaw 1995.

Żbikowski A., Żydzi [Jews], Wrocław 1997. 
Żbikowski A., Teksty pogrzebane $w$ niepamięci. Relacje dwóch uciekinierek $z$ masowego grobu Poniatowa [Texts Buried in Non-Remembrance. Testimonies of Two Escapees from a Mass Grave in Poniatowa], "Zagłada Żydów” 2005, No. 1.

Żbikowski A., U genezy Jedwabnego. Żydzi na Kresach Pólnocno-Wschodnich II Rzeczypospolitej. Wrzesien 1939-lipiec 1941 [The Genesis of Jedwabne. Jews in the Northern-Eastern Borderlands of the Second Republic of Poland: September 1939-July 1941], Warsaw 2006.

Żbikowski A., Żydowscy przesiedleńcy $z$ dystryktu warszawskiego w getcie warszawskim, 1939-1943 [Displaced Jews from Warsaw District in the Warsaw Ghetto 1939-1943], in: Prowincja noc. Życie i zagłada Żydów w dystrykcie warszawskim [Province of the Night. Life and Holocaust of the Jews in Warsaw District], eds. B. Engelking, J. Leociak, D. Libionka, Warsaw 2007.

Żebrowski R., Dzieje Żydów w Polsce. Kalendarium [History of Jews in Poland. Timetable], Warsaw 1993.

Zieliński K., Rewolucja w sztetl? O żydowskich środowiskach małomiasteczkowych $w$ Królestwie Polskim pod koniec XIX i w pierwszych dekadach XX w. [Revolution in Shtetl? On Jewish Small-Town Communities in Kingdom of Poland at the End of the $19^{\text {th }}$ and in the First Decades of the 20 ${ }^{\text {th }}$ Century] (Example of Puławy), in: Historia i kultura Żydów Janowca nad Wisła, Kazimierza Dolnego i Puław. Fenomen kulturowy miasteczka - sztetl. Materiały z sesji naukowej " $V$ Janowieckie Spotkania Historyczne" Janowiec nad Wista 28 czerwca 2003 roku [History and Culture of Jews from Janowiec in the Lublin Voivodeship, Kazimierz Dolny and Puławy. The Cultural Phenomenon of Town - Shtetl. Materials from " ${ }^{\text {th }}$ Janowiec Historical Meetings" Scientific Session, Janowiec in Lublin Voivodeship, 28 ${ }^{\text {th }}$ June 2003], Janowiec in the Lublin Voivodeship 2003.

Zimmerer K., Zamordowany świat. Losy Żydów w Krakowie 1939-1945 [Murdered World. Fate of Jews in Cracow 1939-1945], Cracow 2004.

Ziółkowski M., Pamięć i zapomnienie. Trupy w szafie polskiej zbiorowej pamięci [Memory and Oblivion. Skeletons in the Closet of Polish Collective Memory], "Kultura i Społeczeństwo" 2001, No. 3/4.

Znaniecki F., Socjologiczne podstawy ekologii ludzkiej [Sociological Bases of Human Ecology], "Ruch Prawniczy, Ekonomiczny i Socjologiczny" 1938, No. 1.

Znaniecki F., William I.T., Chłop polski w Europie i Ameryce [Polish Peasant in Europe and America], Warsaw 1976.

Znaniecki F., Humanistyczny współczynnik faktów kulturowych [Humanistic Coefficient of Cultural Facts], in: Znaniecki [Znaniecki], ed. J. Szacki, Warsaw 1986.

Radzik T. (ed.), Żydzi w Lublinie [Jews in Lublin], Lublin 1995.

Tomaszewski J., Żbikowski A. (eds.), Żydzi w Polsce. Dzieje i kultura. Leksykon [Jews in Poland. History and Culture. Lexicon], Warsaw 2001. 



\section{Index}

A

Abramowicz Barbara (Basia) 76

Abucewicz-Szcześniak Monika 216

Ainsztein Reuben 26

Ajzensztajn Betti 169

Aleksandrowicz Julian 116-118, 121,148

Alexander Christopher 213

Altman Irwin 240

Ambrosewicz-Jacob Jolanta 16

Arad Yitzhak 70, 101

Arendt Hannah 26

Ariès Philippe 20, 178, 240

Aron Icchak 89

Arońska Sz. 72

Astman Mina 101

Atkinson John William 133

B

Bachelard Gaston 31, 205

Bachman 83

Baker Yehuda 26

Balint Lea 75

Bańka Augustyn 32, 120, 132, 145, 212, 240

Bańkowska Aleksandra 8, 9, 25, 39, $65,70,71,91,97-100,116,141$, $172,186,231,251,252$

Baranowski Bohdan 216

Bartoszewski Władysław 126

Basista Andrzej 211, 212

Bauman Janina 39, 78

Bazjanac Vladimir 223

Benjamin David N. 223

Benjamin Walter 205

Berg Mary 264

Berger Alan L. 18
Berger Naomi 18

Berger Peter Ludwig 258

Berland Maria 60, 64, 137

Berland Marian 60, 63, 136

Berlands 260

Bertaux Daniel 49, 50

Bettelheim Brunon 123

Biberstein Aleksander 28, 87

Biedka Łukasz 18

Bielski (Bełski) Tuwia 116, 186

Bierzyński-Burnett Ignacy 53, 59

Bigdowski Leon 251

Bikont Anna 28, 90, 95, 129

Blades Mark 31

Blady-Szwajger Adina 219

Błaszczyk Ewa 149

Blumsztajn (Aron and Berek) 251

Bobeszko Jan 251

Boczoń Władysław 28

Bodor Adam 184, 191, 258

Bogucki Jan 79

Boguckis 80

Bogunia-Borowska Małgorzata 19

Bohr Niels 153

Boorstin Daniel Joseph 43

Borzymińska Zofia 71, 174

Brach-Czaina Jolanta 114, 139

Braham Randolph Louis 18

Brauer Hermann 104

Brodski Josif 161, 191

Brunswik Egon 131

Bryskier Henryk 104

Buczkowski Leopold 215, 221, 222

Bukovsky Vladimir 185, 189, 192, 195-197, 201, 202, 258

Buryła Sławomir 45, 122 
C

Cała Alina 87, 90, 162, 235

Calhoun John B. 145, 201

Capps Reilly 263

Caputa Rafał 28

Chaskielewicz Stefan 40, 41, 66, 168, 193, 201

Chiger Ignacy 8, 117, 173

Chomet Abraham 28, 57

Chustecki Józef 232

Chuwis-Thau Lili 138, 193

Cichocki Ryszard 247

Cienki Mendel 95, 96

Ciosek Mieczysław 179, 188, 189, 194, 200

Colman Andrew M. 131

Corbin Alain 177

Czarnecki Witold 32

Czarnowski Stefan 218

Czerniaków Adam 268

Czykwin Elżbieta 246

Czyński Marek 32

Czyżewski Marek 48

D

Datner Szymon 69

Datner-Śpiewak Helena 162, 235

Delumeau Jean 20, 178

Denzin Norman 50, 51

Derczyński Włodzimierz 188

Diamant Tamara 101, 102

Dichter Wilhelm 53, 137, 175

Dilthey Wilhelm 50

Dimant Ita 56, 76

Domańska Ewa 21

Duby George 20

Dulman Zofia 58, 59, 82, 90, 99, 110, 264

Durkheim Emil 21

Dutkiewiczs (Helena and

Wacław) 74
E

Eliade Mircea 155, 159, 178

Elias Norbert 19

Ellenberger Henri 189

Elman Józef (Josif) 251

Emerson Richard 81

Engelking Barbara 8, 20, 21, 25, 27, $37,45,47,69,73,79,87,91,95$, $225,226,256,257,260$

Ernest Stefan 165, 185, 241

F

Fajgenbaum Chaim 235

Fajgenbaums 235

Falk Klara 134

Fater Czesława 163

Federbusch-Ophir Anna 76

Fiałkowski 172

Fidelseid Stella 43, 107, 136, 138, $143,145,146,239,249,264$

Filipkowski Piotr 9, 45

Fink Ida 57, 223

Finkielsztajn Chana 238

Fischbein Fela 95

Fiszerowa Ludwika 105

Fitelberg Edward 250, 251

Flaks 102

Fogelman Dawid 162, 167, 173, 176

Foucault Michel 179

Frančič Mirosław 216

Frank Anne 83

Frejman Szymon 251

Frejnkman Fejga 141

Frisch Michael 45

Frydman Halina 64

Frymet Dwojra 93, 109, 110, 140

Fuks Marian 28, 169

G

Gądecki Jacek 32, 131

Gail Hersz 140 
Genia ze Lviv 106

Gennep Arnold van 159, 177

Geremek Bronisław 216

Gerstenman Rajzel 80

Gerwic Gitla 67

Gibson James J. 131, 132, 134, 207

Giedion Siegfried 208

Gilbert Martin 28

Gildenman Mosze 83

Ginzburg Carl 21

Glaser Barney G. 51

Gliszczyńska Xymena 247

Głowiński Michał 68, 136, 236, 245, 246

Goffman Erving 23, 51, 52, 160, 188,246

Gojawiczyńska Pola 130

Gold John Robert 31

Goldlust 56

Goldstein Chaim Icel 43, 62, 117, $119,135,173,174,176,182,186$, 200, 242-244, 250

Goldsztajn Perec 228

Golledge Reginald George 31

Górwicz 109

Gottowt John 60

Grabarek Helena 121, 150

Grabowski Jan 9, 27, 28, 91, 231

Greenspan Henry 45

Gregier Marzena 159, 160

Gregory Richard Langton 131

Grinbaum Abram 121, 150

Grocher Irena 64, 167, 173

Grodzińska Irena (see Jagur

Orna) 64

Grodziska Karolina 170

Groll Masza 108

Gross Jan Tomasz 18, 29, 38, 39, $128,129,236,259$

Grudzińska-Gross Irena 229

Grupińska Anka 9, 219

Gryglewski Ryszard Witold 176, 177
Grymbal Jan Abram 121

Grynberg Henryk 29, 163, 166, 193, $229,235,248$

Grynberg Michał 25, 28, 42, 169

Grzegrzółka Janina 108

Grzelak Janusz 33

Gutman Israel 28

Guz Alicja

Guz Leon 70, 116, 138, 198, 199

Guzowski 233

$\mathbf{H}$

Haberman Blima 71

Habraken John 213

Hall Edward Twitchell 21, 31, 144, 201, 240

Hanson Joanna K.M. 21

Hass Aaron 18

Haumann Heiko 28

Hechtman Klara 176

Hediger Heini 144

Heidegger Martin 156

Heisenberg Werner 153

Herc Israel 142

Herman 133

Hilberg Raul 26, 27, 28, 218

Himmler Heinrich 84

Hiżowa Emilia 251

Hobfoll Steven 190

Hoffman Eva 88, 89

Hoffman Henryk 64, 65

Holzmann Koppel 53

Hońdo Leszek 16, 171

I

Iglicki Wacław 67

Iranek-Osmecki Kazimierz 28, 75

J

Jabłonka Chaja Sojka 244

Jagielski Jan 9

Jagur Orna (Grodzińska Irena) 64 
Jakubowska Maria 262

Jakubowska Zofia 262

Jałowiecki Bohdan 30, 32, 118, 158

Janowska Katarzyna 137, 206

Jasiewicz Krzysztof 28

Jasińska-Kania Aleksandra 188

Jaspers Karl 122

Jędrzejczyk Dobiesław 30

Jeziorski Ireneusz 28

Jolsons 28

Joselzon vel Jolson Anna 154

Joselzon vel Jolson Leon 154

K

Kac Kima 105

Kaczmarek Jacek 29, 30, 32, 123, 207, 236

Kałowska Sabina Rachel 60

Kamiński Marek M. 180, 194, 195

Kamiński Tadeusz 217

Kamiński Wiesław Andrzej 32, 131

Kantorowicz Jochwed 166, 172, 232, 264

Karpińska Grażyna Ewa 32, 33

Kasjanowicz Katarzyna 219-222, 228, 229, 237

Katz Menachem 43, 117, 136, 137, $142,143,167,195,196,243,244$, 252

Katzmann Friedrich 35, 113, 124

Kaufmann Jean-Claude 214

Kaźmierska Kaja 48

Kenigswein Regina (maiden name

Sobol) 68

Kenigswein Stefania (Stefcia) 68

Kersten Krystyna 17, 85

King Peter 214

Kitchin Robert M. 31

Klukowski Zygmunt 232

Kmieć Piotr 136

Kocielskis (Rozalia and Marian) 63

Kocjan Krzysztof 28
Koffka Kurt 131

Kofta Mirosław 247

Kogan I. 18, 105

Kogan Josif 98

Köhler Wolfgang 131

Kołakowski Leszek 114, 115

Konecki Krzysztof 51

Koper Maria 43, 138, 141, 264

Kopilewicz Łejke 80

Korczak R. 105

Kornblum Dov Władysław

(Władek) 66, 67

Kostański Jan 163, 166, 193, 248

Kotowska Maria 42

Kotula Franciszek 28

Kowalak Tadeusz 218

Kowalski Sergiusz 16

Koźmińska-Frejlak Ewa 8, 17

Koźmińskis 64

Krajewski Mirosław 29

Krajewski Stanisław 16

Krzyczkowska Halina (Halinka) 60

Krzyczkowski Zdzisław (Zdzisio) 60

Kurek Ewa 75

Kuryłowicz Ewa 133

Kuwałek Robert 101

Kwaśniewicz Władysław 48

L

La Capra Dominick 123

Ladurie Emmmanuel Le Roy 21

Lanckorońska Karolina 184

Landsberg M. 43, 135, 137, 139, $140,142,143,147,167,174,175$, $197,241,242,264$

Langer Lawrence 40

Lasotowa Julia 83

Le Bon Gustave 126

Leisner Rut 64, 65, 70, 94, 95

Lejeune Philippe 48

Lejkin Jakub 251

Lenartowicz J. Krzysztof 31, 32, 153 
Leociak Jacek 8, 20, 25, 26, 37, 41, $69,73,79,87,89,103,104,122$, $123,164,178,185,225,226,229$, 231

Lessing Marek 186

Levine Madeline G. 219, 222, 223, 229, 237, 238

Lewandowska Stanisława 20

Lewin Kurt I. 164

Lewinówna Zofia 126

Lewis Oscar 50

Lewycka Marina 172, 173

Libionka Dariusz 24, 25

Lubelska Wanda 174, 181

Lubonja Fatos 199, 201, 202

Luckmann Thomas 258

Łukasiewicz Piotr 85, 219, 220, 229

Lüttwitz Smilo von 130

Lynch Kevin 31

M

Mach Jadwiga 127

Madajczyk Czesław 85, 90, 94

Madurowicz Mikołaj 32

Majewski Florian (Lajbcygier Moshe Aron) 43, 92, 100, 106, 130, 142, $243,244,248,249,250,252$

Makowers (Henryk and Noemi) 271

Malachi Chanina 119, 264

Malachi Hinda (Hindzia) 119, 264

Mans Chawa 108

Maranda Michał 101

Mariańska Miriam 238

Markiewicz Boraks Bronisława 74

Marszałek Józef 100

Maslow Abraham H. 115

Masłowska Janina 106

McClelland David Clarence 133

Meed Władka (Peltel Fajga) 134, 135,176

Meiler Haskiel 127
Melchior Małgorzata 8, 9, 17, 18, 25, $37,38,40,45,47,48,96,97,110$, $227,253,262$

Meroz Anna 63

Michałko Chalmida 238

Michalson-Choniak Estera (Esterka) 76

Midler Helena (Hela) 64

Mikułdowa Maria 141

Mikulski Jan 140

Milch Baruch 111, 147, 165, 169

Miłosz Czesław 84, 93, 210

Mirski Sławek 250

Moczydłowski Paweł 180, 187

Modrzejewski Filip 199

Mróz Kazimierz 233

Mucharski Piotr 137, 206

$\mathbf{N}$

Najberg Leon 104, 205, 233, 250, 251

Najter Sara 82

Nalewajko-Kulikov Joanna 24, 25, 26, 87

Neider C. (Marceli) 224, 225, 233, 239, 243, 264

Neugebauer Henryk 174

Ney Artur 58

Nissenbaum Icchak 169

Nowak Grzegorz 32, 131

Nowaks (Genowefa, maiden name Jakubowska, Władysław, Rozalia and Wiesława) 262, 263

Nussenbaum Szajek 163

O

Obuchowski Kazimierz 247

Ogryzko-Wiewiórkowski Henryk 131

Opoczyńska Małgorzata 156

Orwid Maria 18

Owczynnikowa Olga W. 247 


\section{$\mathbf{P}$}

Paczowski Bohdan 206

Pakuła Zbigniew 29

Palska Hanna 215

Pankiewicz Tadeusz 126

Paulsson Gunnar S. 25-27, 47

Pawełczyńska Anna 100

Pękalska Janina 251

Perechodnik Calel 44, 234

Perks Robert 45

Perrot Michelle 20

Petelewicz Jakub 90, 91, 125, 127

Pietrzykowska Marta 8

Piorun Wacław 210

Piżyc Leon 251

Poławski Paweł 216

Polisiuk Leon 108, 109

Port Lejzor 116

Portelli Alessandro 45

Porteous John Douglas 222, 223

Posesorski Hersz 186

Potaszs (Elo, Rywka, Boruch and Baśka) 73

Potępa Stanisław 28

Potężny Tadeusz (Tadek) 83

Potocki Andrzej 29

Prekerowa Teresa 24, 25, 75, 76, 78, 251

Prost Antoine 20

Przymeński Andrzej 217

Purchla Jacek 170

$\mathbf{R}$

Radzik Tadeusz 29

Rasmussen Steen Eiler 133, 196

Reicher Edward 56, 57

Resler Maks 102, 103

Reykowski Janusz 247

Ringelblum Emanuel 24, 25, 78, 91 , 117, 264

Rittel Horst W.J. 213

Rodak Paweł 45, 122
Rokuszewska-Pawełek Alicja 48, 148, 253

Rosen Samuel 172

Rosenbaum Irving Joseph 169

Rotter Julian 247

Rozenberg Izak 72, 73

Rubinsztajn Irka 104

Rubinsztejn Estera 105

"Rudy" (R.) 139, 142, 143, 147, 175, 242

Russel James A. 31

Rybczyński Witold 43, 207, 211, 213, 214

Ryszka Franciszek 232

S

Schneider Artur 165, 166, 242, 244, 251, 252

Schönker Henryk 59, 60, 105, 251

Schönkers 251

Schulze Winfried 21

Schutze Fritz 253

Selye Hans 145

Semprun Jorge 255, 260, 261

Shapiro Robert Moses 37

Silverstein Leokadia 43, 103, 117, $139,143,173,175,176,193$

Simmel Georg 19

Skibińska Alina 8, 37, 42, 45, 90, 91, $125,127,234,262,263$

Skwirski 168, 169

Slesin Aviva 263

Sobol Elżbieta 22, 68

Sommer Robert 31, 120, 144

Spiss Anna 170

Stasiuk Andrzej 179

Staszek z Warsaw 59

Steinkeller Jakub (Gat Ephraim, "Januszek") 262

Steinkellers (Jakub, Sara and

Fryderyk) 262

Steinlauf Michael 17 
Stokols Daniel 144, 145

Stola Dariusz 28, 75

Strączek Krystyna 149

Strauss Anzelm L. 51, 253

Strelau Jan 190

Strzelecki Jan 123

Studer Raymond G. 213

Summerfield Penny 45

Świątkiewicz Franciszek 79

Sylwester from Osinówka 70, 94

Symotiuk Stefan 32, 131

Szacki Jerzy 51, 52, 188

Szajowski Eugeniusz 62

Szarfenberg Ryszard 218

Szarota Tomasz 20

Szczepański Marek 30, 32, 118, 158

Szczypiorski Andrzej 158, 159

Szenbach 102

Szlengel Władysław 223

Sznajderman Monika 199

Szpilman Władysław 74, 162

Sztok Aron 251

Sztompka Piotr 19, 20, 122

Szwajca Krzysztof 15, 18, 44, 47, 130

Szwarc Josif 98

Szwarc Szulim 62, 63

Szymańska Zofia 75

T

Talenfeld Malka 101

Tarkowska Elżbieta 8, 10, 93, 94, 215

Tec Nechama 37, 168

Thomas Louis-Vincent 177

Thompson Alistair 45

Thompson Paul 48, 49

Tobak Gerszon 252

Tokarska-Bakir Joanna 9, 115

Tola from Jędrzejów 60

Tomaszewski Jerzy 16, 234

Tomaszewski Tadeusz 247

Trojak Jechudit 104
Trokenheim-Szynowłoga Guta 116, 175,250

Trunk Isaiah 26

Tuan Yi-Fu 21, 32, 153, 155, 157, 214

Turner Berl 252

Turner Jonathan 81

Turski Marian 65

Tych Feliks 85, 126, 232

U

Urbański Krzysztof 29

V

Venturi Robert 31

Veyne Paul 20

Vincent Gerard 20

Vitruvius 211

W

Wajnberg Rywka 95, 96, 140

Wajnsztajn Dina 140

Ward Lawrence M. 31

Wąsowicz Aleksander 169, 171

Weber Max 50

Węgrzynek Hanna 87

Weick Karl 258

Weil Simone 207

Weinstock 236

Weiss Szewach 9, 83

Weiss 83

Wertheimer Max 131

Wicker Allan W. 144

Wieczorkiewicz Anna 177

Wienerowa Ryśka 143

Wirth Louis 214

Wiszniewicz Joanna 18

Włodarczyk Janusz Andrzej 32, 134, 135, 206, 208, 210, 211

Włodarek Jan 49

Wohlegelernter Chaim Icchak 92

Wołkowicz Lipa 95, 96 
Wyka Kazimierz 234

Wyrzykowska Antonina 129

Z

Zadrożyńska Anna 158

Zalewska Gabriela 87

Zarycki Tomasz 33

Zimmerer Katarzyna 29, 87

Znaniecki Florian 50, 117

Zorin Szalom 71
Zyskind Sara 57, 186

Żabiński Jan 68

Żbikowski Andrzej 28, 37, 39, 91, 105, 226, 234

Żebrowski Rafał 71

Żeromska Monika 126, 130

Ziółkowski Marek 49

Żółtak Etka 79, 80, 140, 264

Żywulska Krystyna 221 


\section{Studies in Jewish History and Memory}

\section{Edited by Lucyna Aleksandrowicz-Pędich, Jürgen Hensel,}

Sławomir Kapralski and Małgorzata Pakier

Vol. 1 Jan T. Gross (ed.): The Holocaust in Occupied Poland: New Findings and New Interpretations. 2012.

Vol. 2 Lucyna Aleksandrowicz-Pędich / Małgorzata Pakier (eds.): Reconstructing Jewish Identity in Pre- and Post-Holocaust Literature and Culture. 2012.

Vol. 3 Małgorzata Pakier: The Construction of European Holocaust Memory: German and Polish Cinema after 1989. 2013.

Vol. 4 Lucyna Aleksandrowicz-Pędich: Memory and Neigborhood: Poles and Poland in Jewish American Fiction after World War Two. 2013.

Vol. 5 Joanna Auron-Górska: Describing Who? Poland in Photographs by Jewish Artists. 2014.

Vol. 6 Lucyna Aleksandrowicz-Pędich/Jacek Partyka (eds.): Jews and Non-Jews: Memories and Interactions from the Perspective of Cultural Studies. 2015.

Vol. 7 Justyna Kowalska-Leder: Their Childhood and the Holocaust. A Child's Perspective in Polish Documentary and Autobiographical Literature. Translated by Richard J. Reisner. 2015.

Vol. 8 Magdalena M.Wrobel Bloom: Social Networks and the Jewish Migration between Poland and Palestine, 1924-1928. 2016.

Vol. 9 Jacek Nowak / Sławomir Kapralski / Dariusz Niedźwiedzki: On the Banality of Forgetting. Tracing the Memory of Jewish Culture in Poland. 2018.

Vol. 10 Łukasz Tomasz Sroka: In the Light of Vienna. Jews in Lviv - between Tradition and Modernisation (1867-1914). 2018.

Vol. 11 Marta Cobel-Tokarska: Desert Island, Burrow, Grave - Wartime Hiding Places of Jews in Occupied Poland. 2018.

www.peterlang.com 
